BUILDING A 'DEMENTIA-FRIENDLY' NEIGHBOURHOOD:

AN EXAMINATION OF THE ECONOMIC COSTS OF IMPLEMENTING 'DEMENTIA-FRIENDLY' URBAN DESIGN AND LAND USE STRATEGIES IN WHITBY, ONTARIO

by

\author{
Samantha Biglieri \\ B.A. (Honours), Queen's University, 2013 \\ A Major Research Paper \\ presented to Ryerson University \\ in partial fulfillment of the requirements for the degree of \\ Master of Planning \\ in \\ Urban Development
}

Toronto, Ontario, Canada, 2015

(c) Samantha Biglieri 2015 


\section{Author's Declaration for Electronic Submission of a MRP}

I hereby declare that I am the sole author of this MRP. This is a true copy of the MRP, including any required final revisions.

I authorize Ryerson University to lend this MRP to other institutions or individuals for the purpose of scholarly research

I further authorize Ryerson University to reproduce this MRP by photocopying or by other means, in total or in part, at the request of other institutions or individuals for the purpose of scholarly research.

I understand that my MRP may be made electronically available to the public. 


\title{
BUILDING A 'DEMENTIA-FRIENDLY' NEIGHBOURHOOD: AN EXAMINATION OF THE ECONOMIC COSTS OF IMPLEMENTING 'DEMENTIA-FRIENDLY' URBAN DESIGN AND LAND USE STRATEGIES IN WHITBY, ONTARIO
}

\author{
(c) Samantha Biglieri, 2015 \\ Master of Planning \\ in \\ Urban Development \\ Ryerson University
}

\begin{abstract}
Cases of dementia in Ontario will grow from 181,000 to 466,000 by 2036 . This accelerating crisis has sparked research on how to design neighbourhoods for those persons with mild to moderate dementia, and how to empower them through built environment changes to remain in their community for as long as possible. There are numerous benefits for persons with dementia who continue access to their neighbourhood including: physical activity, sense of dignity, social interaction, autonomy, and psychological wellbeing. This MRP examines 17 Recommendations (urban design and land use strategies) identified as 'dementia-friendly', within dementia design and planning literature. Each is then examined against the planning frameworks for Whitby, Ontario, and assessed for its economic impact on a base case subdivision using pro forma analysis. The effect on the financial return for a developer was minimal, demonstrating that establishing these recommendations as policy is viable, through regulation and incentives.
\end{abstract}

Key words: "dementia-friendly" "urban design" "financial feasibility" "planning recommendations" "built environment" 


\section{Acknowledgements}

I want to thank my family, Parth and my dog Mo for putting up with my never ending ramblings about cities, seniors, planning law, Whitby, public health, property taxes, politics... did I mention seniors? I especially want to thank my Dad, for inspiring me not only to join his profession and alma mater, but for being so patient with my incessant planning questions, day after day. Thank you for always believing in me.

I want to thank every single faculty member in the School of Urban and Regional Planning. I do not think they know the extent to which they have made a difference in my life and helped me with this journey. Thank you.

For this MRP, I want to send a special thank-you to Professor Steven Webber, for putting up with my never-ending pro forma questions, in a way that never made me feel silly. To my supervisor Professor Ron Keeble for providing amazing insight into this project, for steadily pushing me along and for always being there with a wise or calming word. (Which I ended up needing more than I care to admit.) Finally, I want to thank Professor Mitch Kosny for talking to a confused $4^{\text {th }}$ year undergrad and convincing her to come to this great school. Above all, I am thankful for him giving me opportunities I could not have dreamed of, and for pushing and inspiring me to greater things.

Most all, I want to thank my classmates - for all the times we suffered together, played volleyball together, celebrated together, laughed together and most of all, for continuing to inspire me every day. You have all taught me so much and I will always be eternally grateful for that.

Here's to you.

\section{Dedication}

I want to dedicate this paper to all of my grandparents, whose influence on my life is difficult to sum in a few words, but here goes:

To my Poppa, who taught me that you cannot be good at something on the first try, and that when you get knocked down, you always get back up again. To my Nanny, who taught me to look on the bright side of life, and whose battle with Alzheimer's disease inspires me every day. To my Nonna, who taught me no matter the circumstances, you have to have an open heart and love to give. To my Nonno, who never got lost and taught me the value of loving the land and the meaning of the places you come from. Finally, to my Great Gran, who always said, "We'll all get old if we live long enough!"

This is for you. 


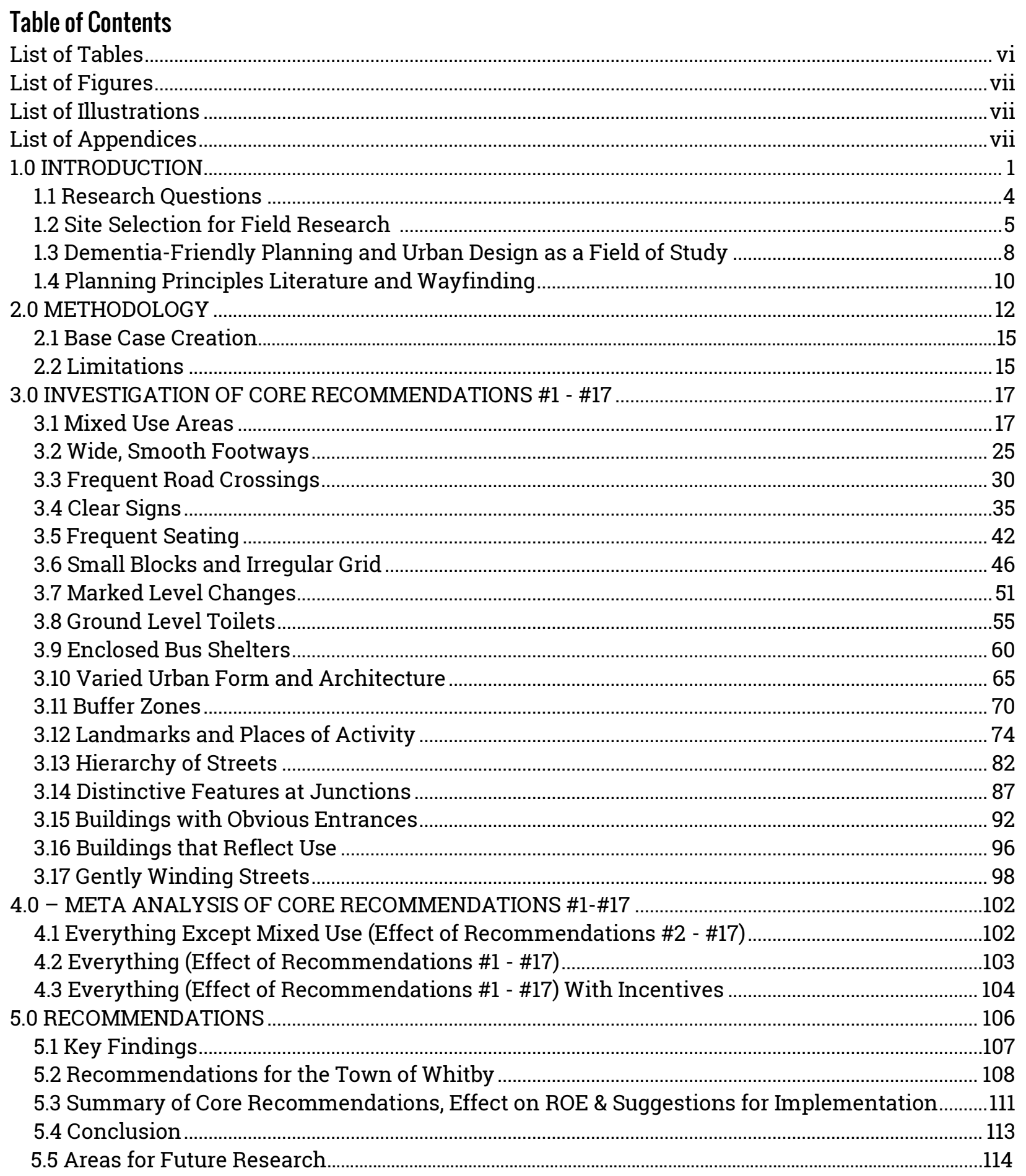




\section{List of Tables}

Table 1: Summary of the Selected Key Literature Articles from Keady et al. (2012) for use in evaluating the 17 Core Recommendations

Table 2: Summary of Other Key Dementia Literature Used to Evaluate the 17 Core

Recommendations

Table 3: ROE Comparison (Mixed Use Areas)

Table 4: Incentives Summary (Mixed Use Areas)

Table 5: Current Planning Frameworks (Wide, Smooth Footways)

Table 6: ROE Comparison (Wide, Smooth Footways)

Table 7: Current Planning Frameworks (Frequent Road Crossings)

Table 8: Calculations for Intersection Treatments

Table 9: ROE Comparison (Frequent Road Crossings)

Table 10: Current Planning Frameworks (Clear Signs)

Table 11: ROE Comparison (Clear Signs)

Table 12: Current Planning Frameworks (Frequent Seating)

Table 13: ROE Comparison (Frequent Seating)

Table 14: Current Planning Frameworks (Small Blocks and Irregular Grid)

Table 15: ROE Comparison (Small Blocks, Irregular Grid and Winding Streets)

Table 16: Current Planning Frameworks (Marked Level Changes)

Table 17: ROE Comparison (Marked Level Changes)

Table 18: Current Planning Frameworks (Ground Level Toilets)

Table 19: ROE Comparison (Ground Level Toilets)

Table 20: Current Planning Frameworks (Enclosed Bus Shelters)

Table 21: ROE Comparison (Enclosed Bus Shelters)

Table 22: Calculations for New House Designs

Table 23: ROE Comparison (Varied Urban Form + Architecture)

Table 24: Current Planning Frameworks (Buffer Zones)

Table 25: ROE Comparison (Buffer Zones)

Table 26: Current Planning Frameworks (Landmarks + Places of Activity)

Table 27: ROE Comparison (Landmarks + Places of Activity)

Table 28: Current Planning Frameworks (Hierarchy of Streets)

Table 29: Current Planning Frameworks (Distinctive Features at Junctions)

Table 30: Costs for Distinctive Features at Junctions

Table 31: ROE Comparison (Distinctive Features at Junctions)

Table 32: Current Planning Frameworks (Buildings that Reflect Use)

Table 33: Current Planning Frameworks (Gently Winding Streets)

Table 34: ROE Comparison (Everything Except Mixed Use - Effect of Recommendations \#2 - \#7)

Table 35: ROE Comparison (Everything - Effect of Recommendations \#1 - \#17)

Table 36: ROE Comparison (Everything with Incentives - Effect of Recommendations \#1 - \#17)

Table 37: Overall ROE Comparison 


\section{List of Figures}

Figure 1 - Average of median distance travelled from home for three cognitive groups

Source: Shoval et al., 2011, p. 860

Figure 2 - Clearview Font, used for its high visibility on Highway Systems in USA

Source: Highway Sign in Farmington Hills, MI installed in 2005, Westbound on I-696

http://en.wikipedia.org/wiki/Clearview_\%28typeface\%29\#/media/File:ClearviewBGS-I696W-

I275-I96.JPG

Figure 3 - Curb Ramp Diagrams

Source: Town of Whitby Accessibility Standards, 2005

Figure 4 - Accessible Toilet Design

Source: Town of Whitby Accessibility Standards, 2005

Figure 5 - Fully Automated Pay Toilet, Toronto

Source: Hauch, Toronto Star, July $4^{\text {th }}$, 2013. Retrieved from:

http://www.thestar.com/news/gta/2013/07/04/visit_to_torontos_palatial_potty_not_always _flush_with_success.html

Figure 6 - Figure 6 - Typical Community Post Box Design (Canada Post)

Source: http://www.integritassecuritygroup.com/wp-content/uploads/2014/01/mailbox-

security-Surrey.jpg

Figure 7 - Post Box Pavilion

Source: R. Keeble, 2015

\section{List of Illustrations}

Illustration 1: Base Case Scenario

Illustration 2: Small Blocks, Irregular Grid and Winding Streets.

\section{List of Appendices}

Appendix 1A - Base Case Pro Forma Assumptions

Appendix 2A -Mixed Use Pro Forma Assumptions

Appendix 2.1A - Mixed Use Pro Forma Assumptions - 5\% Development Charge Waiver

Appendix 2.2A - Mixed Use Pro Forma Assumptions - 25\% Parking Reduction

Appendix 2.3A - Mixed Use Pro Forma Assumptions - All Incentives

Appendix 3A - Wide, Smooth Footways Pro Forma Assumptions

Appendix 4A - Frequent Crossings Pro Forma Assumptions

Appendix 5A - Clear Signs Pro Forma Assumptions

Appendix 6A - Frequent Seating Pro Forma Assumptions

Appendix 7A - Small Blocks, Irregular Grid and Winding Streets Pro Forma Assumptions

Appendix 8A - Marked Level Changes Pro Forma Assumptions

Appendix 9A - Ground Level Toilets Pro Forma Assumptions

Appendix 10A -Enclosed Bus Shelters Pro Forma Assumptions

Appendix 11A -Varied Urban Form + Architecture Pro Forma Assumptions

Appendix 12A - Buffer Zones Pro Forma Assumptions

Appendix 13A - Landmarks + Places of Activity Pro Forma Assumptions 
Appendix 14A - Distinct Features at Junctions Pro Forma Assumptions

Appendix 15A -Everything Except Mixed Use (The Effect of Core Recommendations \#2-\#17) Pro Forma Assumptions

Appendix 16A - Everything (The Effect of Core Recommendations \#1-\#17) Pro Forma Assumptions Appendix 17A - Everything with Incentives (The Effect of Core Recommendations \#1-\#17) Pro Forma Assumptions

Appendix 1B - Base Case Pro Forma (Excel Spreadsheet)

Appendix 2B - Mixed Use Pro Forma (Excel Spreadsheet)

Appendix 2.1B - Mixed Use Pro Forma - 5\% Development Charge Waiver (Excel Spreadsheet)

Appendix 2.2B - Mixed Use Pro Forma - 25\% Parking Reduction (Excel Spreadsheet)

Appendix 2.3B - Mixed Use Pro Forma - All Incentives (Excel Spreadsheet)

Appendix 3B - Wide, Smooth Footways Pro Forma (Excel Spreadsheet)

Appendix 4B - Frequent Crossings Pro Forma (Excel Spreadsheet)

Appendix 5B - Clear Signs Pro Forma (Excel Spreadsheet)

Appendix 6B - Frequent Seating Pro Forma (Excel Spreadsheet)

Appendix 7B - Small Blocks, Irregular Grid and Winding Streets Pro Forma (Excel Spreadsheet)

Appendix 8B - Marked Level Changes Pro Forma (Excel Spreadsheet)

Appendix 9B - Ground Level Toilets Pro Forma (Excel Spreadsheet)

Appendix 10B - Enclosed Bus Shelters Pro Forma (Excel Spreadsheet)

Appendix 11B - Varied Urban Form + Architecture Pro Forma (Excel Spreadsheet)

Appendix 12B - Buffer Zones Pro Forma (Excel Spreadsheet)

Appendix 13B - Landmarks + Places of Activity Pro Forma (Excel Spreadsheet)

Appendix 14B - Distinct Features at Junctions Pro Forma (Excel Spreadsheet)

Appendix 15B - Everything Except Mixed Use (The Effect of Core Recommendations \#2-\#17) Pro Forma (Excel Spreadsheet)

Appendix 16B - Everything (The Effect of Core Recommendations \#1-\#17) Pro Forma (Excel Spreadsheet)

Appendix 17B - Everything with Incentives (The Effect of Core Recommendations \#1-\#17) Pro

Forma (Excel Spreadsheet)

Appendix 18 - Community Improvement Planning (Description and Process Graphic)

Appendix 19 - List of Current Planning Frameworks

Appendix 20 - Frequency of the 17 Core Recommendations in the Selected Dementia + Built

Environment Literature 


\section{CHAPTER 1: INTRODUCTION}

An aging and increasingly urban population is the greatest demographic shift in our lifetime; and with it comes one of the most deadly, highly stigmatized and prevalent disorders - Alzheimer's Disease and Related Dementias (ADRD). ADRD will affect 114 million people worldwide by 2050, costing billions of dollars to healthcare systems (Gräske et al., 2012, p. 204). Today, ADRD affects approximately $8 \%$ of people 65 and over, and $35 \%$ of people over the age of 85 , according to Canada's Senate Committee on Aging (McDonald, 2011, p. 15). In particular, 905 areas of the GTA will be hit the hardest, as these are the regions the baby boomers tended to settle in. According to Hopkins (2014), "These huge increases will put significant strains on their local healthcare facilities, especially if effective planning is not started immediately," (p.3). This planning should not be limited to the creation of long-term care facilities however, as this only represents the most severe end of the spectrum for someone with ADRD.

The earlier stages of ADRD are most often spent at home, and community settings may make ADRD sufferers anxious and afraid. This may lead to seclusion, therefore decreasing their ability to participate in their community and have a good quality of life, not to mention that isolation and loneliness have a large impact on the advancement of the disease (Bickel \& Cooper, 1994). 'Dementia-friendly' communities are a response to this - an attempt to make communities more legible, distinctive, accessible, comfortable, and safe, in order to prolong a good quality of life for persons suffering from dementia and save in healthcare costs. It is widely recognized that keeping ADRD sufferers within their communities (and not in a long-term care facility) for as long as possible is one of the most effective strategies for the healthcare system. In addition, making the move to a long term care facility can have very negative consequences on the mental and physical well-being of someone with dementia. Having to adapt to new surroundings, timetables, and space is very difficult when one has lost their ability to utilize their short term memory. It has also been 
proven that those with ADRD who have access to the outdoors (especially views of nature), maintain some independence and exercise regularly vastly reduce the need for anti-psychotic drugs, and people are less anxious and sleep better (Pollock \& McMair, 2012, p. 23-42).

Developing communities that are walkable, have good access to transit and are not cardependant have been found by the Medical Officers of Health in the GTHA (2014) in their study, "Improving Health by Design in the Greater Toronto-Hamilton Area," to result in mentally and physically healthier people. There have been many studies on what the increased risk factors are for those with dementia, and what one can do to decrease their risk of developing the disease. The best thing that one can do to decrease their risk of dementia is not extra crossword puzzles or Sudoku, but is to lead a physically active lifestyle from a young age that continues throughout one's life. As the 'Improving Health by Design' report states, the way residential communities are currently designed is destroying the possibility of a healthy active lifestyle by forcing us to rely on the automobile. In order to encourage a healthy lifestyle, walkable communities must be built, and according to the neuro-scientific research, this is one of the best ways to decrease the chances of someone developing dementia. Physical activity is also cited as a way to decrease anxiety and improve cognitive ability in those already diagnosed with dementia.

If planners do not design neighbourhoods so that they are walkable, as well as comfortable, safe, familiar, distinct, accessible and legible, people with ADRD are more likely to remain within their homes and miss out on the very real benefits of physical activity, not to mention a sense of independence, and connections to a social network. It is for these reasons that it is imperative for professional planners to consider 'dementia-friendly' planning in their work. 'Dementia-friendly' planning is a body of research on how to utilize urban design and land use strategies which empower those with dementia symptoms to remain active in their community. For the purposes of this MRP, 'persons with dementia' will also be used to describe persons with ADRD from this point forward. 
In the professional planning world, Przydatek (2012) discovered through her examination of Official Community Plans in British Columbia that key words associated with the five themes of designing for dementia (legible, distinctive, accessible, comfortable and safe) were majorly absent. Przydatek (2012) also found that while planners are open to learning more about dementia-friendly design, it is not something that is on their radar (p. 105, 108). In order for the average professional planner to consider dementia-friendly design and planning, it has to be written into the legislation they use every day.

Another reason for this project is that literature and planning practice has often excluded cognitive impairment from the discussion of accessibility and human rights. Blackman et al. (2003) note, "Although both physical impairment and dementia are increasing in aging societies, far more emphasis has been given to the poor 'fit' between psychomotor capacities and the organization of space than between psychological capacities and the organization of space," (p. 359). In the Canadian context, the Accessibility for Ontarians with Disabilities Act recognizes persons with a cognitive disability in Section 2: Definitions,

"In this Act, "disability" means,

(b) a condition of mental impairment or a developmental disability, (c) a learning disability, or a dysfunction in one or more of the processes involved in understanding or using symbols or spoken language, (d) a mental disorder"

Within the AODA, 2005, there are provisions to implement standards as regulations in order to overcome barriers for the persons outlined with a disability in Section 2 of the Act. These regulations are called "accessibility standards" and they define "barriers" which "means anything that prevents a person with a disability from fully participating in all aspects of society because of his or her disability, including a physical barrier, an architectural barrier, an information or communications barrier, an attitudinal barrier, a technological barrier, a policy or a practice; ("obstacle")." 
However, the only regulation that is concerned with altering environments are for new public buildings and even then, regulations are centered around the needs of those with sensory or mobility disabilities, not those with cognitive disabilities (Regulation 191/11). Currently, there are activist groups pushing for built environment regulations to add to AODA, but again, they focus on the needs of those with a sensory or mobility disability. This MRP investigation could demonstrate to lawmakers that there are tangible changes that can be made to the built environment that will help people with dementia, as well as people with sensory and mobility impairments. In evaluating the cost to a developer of implementing dementia-friendly design, there is the potential for activists to use this document as a tool for negotiation with the province or municipalities. Lastly, for persons with dementia, the benefits of using local streets seem to provide five key benefits:

1. Freedom and autonomy

2. Dignity and sense of worth

3. Fresh air and exercise (physical health)

4. Psychological wellbeing and enjoyment (mental health)

5. Social interaction (Burton \& Mitchell, 2006, p.39-41)

Designing streets that are more legible, comfortable, accessible, safe, and familiar benefit people in all life stages. The fact is that everyone ages, and that everyone will become disabled at some point in their life. That is why it is important to create spaces that will enable all of us when we get older or become less able, to continue to do the things we love, like go for a walk to the store. Enabling older persons to remain active is the key to preventative medicine.

\subsection{RESEARCH QUESTIONS}

The intended subject of this research is dementia-friendly community planning. The idea that changing the built environment for those suffering from ADRD (Alzheimer's disease and Related Dementias) can have an impact on their quality of life and progression of the disease has been studied at the site-specific level (ex. within buildings like long term care homes or hospitals). It is 
however, a relatively new and under researched issue from an urban planning perspective, specifically through urban design and land use organization. This is a planning issue that deals with the both the organization of built form/street layout and people scale design. Considering this and the multi-dimensional nature of the problem, the following research questions have been selected to guide this research project:

1. Can best practices of urban design and land use organization for building a dementiafriendly community on greenfield be identified?

2. Once these findings have been identified and sorted into individual urban design and land use recommendations:

a. Do they each represent good planning principles?

b. Do they fit with existing planning legislation?

c. What are the economic implications of implementing each recommendation to a residential developer of a greenfield site in Whitby, Ontario?

3. How could these findings be incorporated in the current planning process in a specific municipality in Ontario?

\subsection{SITE SELECIION FOR FIELD RESEARCH}

The field location of this research is the Town of Whitby, Ontario, located in the Regional Municipality of Durham, east of Toronto. I will be using the Province of Ontario as it is the planning legislation context I know the most about. I have chosen Whitby for five reasons: (1) I am familiar with the municipality; (2) the municipality is part of a Region that is projected to see a $260 \%$ in the number of persons affected by ADRD by 2036, from 6,725 cases in 2010 to 24,355 by 2036 . This greatly exceeds the provincial average of 156\% (Hopkins, 2011, p. 5, 59); (3) under the 2013 consolidated Regional Official Plan, Whitby is required to double the number of dwelling units by $2031,55 \%$ of which will be in greenfield areas, and $45 \%$ in already built up areas (Schedule E - Table E9, p. 270). This means that there is the opportunity to shape policies that address greenfield development; (4) the Town of Whitby is medium-sized, lower tier municipality with a population of 122,022, making their Official Plan and Zoning By-laws a more manageable size; and (5) the Town is made up of mostly single family style development in the south and small clustered communities 
in the north amidst a fairly rural setting. There is thus opportunity to build dementia-friendly communities that take advantage of the rural setting.

Planning within the Town of Whitby is governed by the following documents:

- Provincial

- Planning Act, 1990

- Provincial Policy Statement, 2014

- Growth Plan for the Greater Golden Horseshoe, 2006

- Region of Durham

○ Official Plan, 2013

- Town of Whitby

- Official Plan, 2010, Office Consolidation 2013

- Zoning By-law 2585, Office Consolidation, 2014

- Engineering Design Criteria, 2011 (also referred to as "Engineering Standards")

- Landscape Plan Guidelines for Site Plan and Subdivision Developments, 2015 (nonstatutory)

The Town of Whitby also has an Accessibility Advisory Committee (AAC), which is a committee of Council that meets at a minimum of six times per year (Town of Whitby, "Accessibility Advisory Committee - Role," 2015). The AAC has the responsibility to comment on Official Plans, Zoning By-laws, and applications for Draft Plan of Subdivision and Site Plan. The AAC, along with the Planning and Public Works department, developed the Accessibility Standards, 2005 as per Provincial Regulation 191/11. These standards only apply to municipality owned facilities (which includes parks, recreation centers, libraries, and walks), however Staff may encourage private facilities to follow the standards. According to a Personal Communication with Planning Consultant \#2 (March 17, 2015), the AAC comments most often on Site Plans. While they do have the power to make suggestions, the developer is not obligated to fulfill their recommendations. In addition, Section 3.0 of the Accessibility Standards, it states that facilities with residential occupancies are exempt from these standards.

Since many of the recommendations to be analyzed are of an urban design nature, it is worthwhile to mention a study done by Meridian Planning Consultants with the assistance of 
planningAlliance in 2011 on Whitby's approach to urban design, as part of the Official Plan Review ${ }^{1}$.

The recommendations made by this study are valuable as it gives an overall snapshot of why the majority of greenfield in Whitby is being developed the way it is, with typical single use zoning and monolithic low density development. The Study also mentions that if Whitby wants to become 'agefriendly' a number of policies have to be changed and streamlined. The study is also influential to this report as it details where and how urban design has to be enforced from in order to be successful. The recommendations from the study by Meridian Planning Consultants and planningAlliance (2011, p.30-33) are summarized below:

1. That Whitby implement an overall design vision for the Town. (Not adopted as of March 31, 2015);

2. That Whitby add a Guiding Principle in their Official Plan that has specific reference to urban design. (Not adopted as of March 31, 2015);

3. The current OP and ZBL leaves the urban design features up to the Zoning by-law stage. This means that zone standards are "not clearly guided by a related Official Plan policy [which] leaves the intent and purpose of that standard susceptible to conflicting interpretation and application, and potentially more difficult to uphold in the event of a sitespecific amendment and/or appeal," (p.31). The Town of Whitby should implement Official Plan directions for urban design and then tie them to the Zoning by-law is order to be effective (they could in addition, be tied to urban design guidelines as well).

4. The Town should create an overall urban design vision for each land use type in the Official Plan (Not adopted as of March 31, 2015);

5. Currently Section 6.2 of the OP has high level directions for urban design, but they are too high level to "address any of the issues faced by the Town," (p.32). They recommend that the urban design policies in the Official Plan should be updated to include emerging specific planning issues, like age-friendly cities, or sustainability. (The Port Whitby Sustainable Community Design Guidelines is a pilot project, but this recommendation has not been incorporated in the OP as of March 31,2015);

6. There are many urban design documents currently used by Whitby including Secondary Plans and non-statutory plans. Often they do not have an underlying objective - and the report recommends that the Official Plan stipulate policies on how to create these area specific plans so that they are developed in a more comprehensive way. (Not adopted as of March 31, 2015);

7. The Study encourages the creation of an urban design checklist, to be given to developers and submitted as part of an application. It would summarize all of the comprehensive and applicable urban design guidelines for the site and require the applicant to tick them off. (Not adopted as of March 31, 2015).

1 The full name of the document is "Whitby Official Plan Review: Planning Our Built Environment, Draft Policy Discussion Paper." 
The recommendations made by this Study will help inform how to potentially implement the 17 Core Design Recommendations.

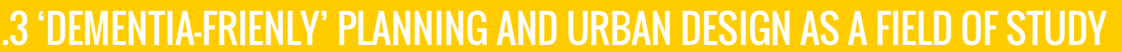

There have been numerous studies on how to design environments for those with dementia, but they are often focused on long term care facilities, and most commonly, on people with moderate to severe dementia. There is also a substantial body of literature on how to design gardens for people with dementia, but again it is focused on gardens and architecture within care facilities.

In terms of wayfinding, an early study on people with dementia were done by Romedi Passini, an environmental psychologist who wrote "Wayfinding in Architecture" in 1984. Passini (1998) called wayfinding 'spatial problem solving' where one must think of their overall plan as well as the individual steps to get there, while making sense of the environmental information. He discusses these three interrelated cognitive processes in detail:

1. Developing a decision plan or plan of action. (This involves higher order actions like 'going to the dentist' but does not lead directly to behavioural action and requires further actions to be implemented).

2. Executing decisions within the plan, transforming it into actions and behaviours at the right time and place. (Such as getting up or passing through a door).

3. Gathering and processing environmental information to sustain the first two actions.

Passini's (1998) research compared the different kinds of decisions made by those with ADRD and a control group of the same age as they navigated the way to a doctor's office within a hospital from a bus stop outside. His study came to the following conclusions:

- 2 out of the 14 participants with dementia were able to develop an overall plan.

- While the participants with dementia's ability to engage in cognitive mapping was diminished, there is no indication that they did not understand architectural elements.

- Open spaces are easier to understand for participants with dementia and creating safe routes are very important.

These findings from Passini demonstrate that the way people with dementia wayfind is different from those without a cognitive impairment. While his study was important, it was conducted 
within a hospital setting which is controlled and differs from the outside environment. The first study to examine neighbourhood features such as urban design and land use for people with dementia was done by Dr. Lynne Mitchell and Professor Elizabeth Burton, both of the WISE (Wellbeing in Sustainable Environments) Research Institute at the University of Warwick, UK.

Mitchell is a member of the Royal Town Planning Institute and Burton a registered architect and urban designer. Their work since 2004 has included qualitative and quantitative research resulting in urban design, street and built form recommendations. Their major research project of 45 persons with dementia in the UK resulted in 77 recommendations that can be grouped into six categories - familiarity, legibility, distinctiveness, accessibility, comfort and safety - with 17 core recommendations from all scales (from street layout to furniture) to be incorporated into new developments or retrofit old ones (Mitchell \& Burton, 2012, p.121). These have been incorporated into the UK Department of Communities and Local Government's publication "Lifetime Neighbourhoods," a series of guidelines for planners and other practitioners on how to design communities that allow seniors to "maintain their independence, enjoy a good quality of life, and take an active role in their communities," (Bevan \& Croucher, 2011, p. 8).

This list of 17 Core Recommendations is the only prescriptive and comprehensive list of urban design characteristics and land use strategies a professional planner could incorporate into a Plan of Subdivision. It is also the most often cited study. The other most influential study is Keady et al. (2012)'s realist review of the literature "on the areas intersecting within and between the neighbourhood, dementia and neighbourhood interventions, including population-based studies and public health approaches," (p.151). Keady et al. (2012) reviewed over 1347 studies completed between 1980 and 2011, and identified 18 key documents. The authors further identified that 14 of the 18 documents "informed [their] analysis and formed the substantive element of the core literature," (p. 152). These 14 key documents represent the best research right now on the relationship between the built environment and people with dementia. 


\subsection{PLANNING PRINCIPIES IITERATURE AND WAYFINDING}

Much of the 'dementia-friendly' literature is concerned with people's ability (and in the case of those with dementia, decreased ability) to wayfind in space. In order to understand wayfinding from a planning principles perspective, this research has turned to the 'Image of the City' by Kevin Lynch. Lynch, an urban planner and Professor authored the book in 1960 - a book that would become required reading in planning and urban design schools across North America. Lynch (1960) coined the terms 'imageability' and 'wayfinding' and emphasized that the basis for good urban design should come from human perceptions of it. Lynch (1960) wanted to study the legibility of cities by exploring the "mental image of that city which is held by its citizens," (p.2). He defined legibility as "the ease with which [the city's] parts can be recognized and can be organized into a coherent pattern," (p.3). Lynch discusses how "wayfinding is the original function of the environmental image and the basis on which its emotional associations may have been founded," and how ancient cultures and animal species as well as people today use the environment around them as a way to produce meaning and fundamentally the environment "permit[s] purposeful mobility" and is a way to survive (p. 125, 124).

Perhaps most importantly for this MRP, Lynch discusses the feeling of being lost and how quickly anxiety and terror can overcome us, suggesting that the ability to interpret one's environment has a great effect on wellbeing and "a sense of emotional security," (p.4). He notes that, "The symbolic organization of the landscape may help to assuage fear, to establish an emotionally safe relationship between men and their total environment," (p.127). It is also a welldocumented fact in the study of the human brain that anxiety disrupts the capacity of an able minded person to problem solve and think clearly - imagine how heightened this would be for someone with dementia. Not only is it much more likely to happen, but the effect of anxiety and feeling lost would be acute. 
"Despite a few remaining puzzles, there now seems unlikely that there is any mystic instinct' of wayfinding. Rather there is a consistent use and organization of definite sensory cues from the external environment. This organization is fundamental to the efficiency and to the very survival of free-moving life," (p.3).

The role of the planner for Lynch (1960) was researching the two way process that defined environmental images - the relationship between the observer and his environment. Planners should study how most people conceptualize their environment (known as 'public images'2) and this will allow city planners "to model an environment that will be used by many people." Lynch emphasized the need to understand these mental pictures by examining several different groups of people. This MRP aims to bring the environmental images of one of the groups that has not been considered in the past - persons with dementia.

Using case studies of American cities, Lynch would come to develop a system for identifying the image of the city through five elements: paths, edges, districts, nodes, and landmarks. Each of the 17 Core Recommendations explored in this MRP will be compared to Lynch's work on these elements and how they relate to each other to produce legible space. Interestingly, Lynch's method including surveying people while they were outside, in space, and this is same method employed by Burton \& Mitchell (2006) who created the 17 Core Recommendations.

The next chapter will discuss the method for evaluating the economic cost of implementing 'dementia-friendly' urban design and land use strategies in the Town of Whitby.

2 Defined by Lynch (1960) as “the common mental pictures carried by large numbers of a city's inhabitants: areas of agreement which might be expected to appear in the intersection of single physical reality, a common culture, and a basic physiological nature." (p.7) 


\section{CHAPTER 2: METHODOLOGY}

An under-researched concept, 'dementia-friendly' planning and urban design for communities and cities has primarily been done by Dr. Lynne Mitchell and Professor Elizabeth Burton. Their list of 17 design recommendations (Burton \& Mitchell, 2006) is the only prescriptive and comprehensive list of urban design and land use strategies a professional planner could incorporate into a Plan of Subdivision. That being said, there have been other studies completed that examined the how people with mild to moderate dementia interact with the world beyond their front door. In order to encompass the aforementioned studies on persons with dementia and their experience in outdoor space, as well as how these recommendations relate to other planning principles, this paper will examine each of the 17 Core Recommendations from four perspectives:

\section{(1) Is the recommendation supported by other dementia specific experience with design research?}

Each of the 17 Core Recommendations will be compared a list of the ten key bodies of work from Keady et al. (2012)'s realist review of the literature "on the areas intersecting within and between the neighbourhood, dementia and neighbourhood interventions, including populationbased studies and public health approaches,' (p.151) as well as four other studies (the reasons for which are explained in Table 1). Keady et al. (2012) reviewed over 1347 studies completed between 1980 and 2011, and identified 18 key documents. The authors further identified that 14 of the 18 documents "informed [their] analysis and formed the substantive element of the core literature," (p. 152). ${ }^{3}$ Of those 14,4 are a product of the original study completed by Burton \& Mitchell (2006). Since the 17 Core Recommendations are a product of the same study, those articles identified by Keady et al. (2012) but based on the Burton \& Mitchell (2006) study will be omitted. Each of the 17 Core Recommendations from Burton \& Mitchell's (2006) study will be compared to each of those 10 articles as outlined in Table 1. In addition, in order to remain as current as possible, 4

\footnotetext{
3 The reasons for inclusion/exclusion of articles are outlined in Tables 1 and 2.
} 
articles/reports will be added to the review for each recommendation (as outlined in Table 2). The

frequency of each of the 17 Core Recommendations in the selected pieces of literature is

summarized in Appendix 20.

(2) Is the recommendation supported by good planning principles and existing legislation?

Each of the 17 Core Recommendations will be examined using:

- The quintessential book on good urban design and city patterns by Kevin Lynch, "The Image of the City' published in 1960.

- ResilientCity's "Urban Design Principles". ResilientCity is a worldwide non-profit network and organization of urban planners, architects, engineers, landscape architects and designers "whose mission is to develop creative, practical, and implementable planning and design strategies that help increase the capacity for resilience of our communities and cities to the future shocks and stresses associated with climate change, environmental degradation, resource shortages, in the context of global population growth." Started by Canadian architect, pioneer in the field of urban resilience and DIALOG Principal Craig Applegath, the principles draw on three major works ${ }^{4}$ and have shaped the debate on how neighbourhoods and cities should be designed in order to be resilient to the present and future effects of climate change. These principles provide a unique and important perspective, especially in the context of a municipality that is affected by urban sprawl.

- Existing documents governing the profession of planning in the context of Whitby, Ontario in order to provide location based context. ${ }^{5}$

\section{(3) How could the recommendation be accurately measured?}

This can be done through several means including:

- Sketching typical subdivision street layouts and adjusting to fit Core Recommendations;

- Using suggestions from Burton \& Mitchell (2006), such as placing public seating every 100$125 \mathrm{~m}$ of road;

- Using estimations from key informants (described below) and key literature;

- Using industry standard pro forma analysis based on a 'first cut' analysis as learned in PL8309: Urban Investments, taught by Professor Steven Webber, an academic and professional planner at Ryerson University with over 25 years' experience studying the land development industry.

\footnotetext{
4 Including: 'The Up Side of Down' by Thomas Homer Dixon, 'Climate Wars' by Gwynne Dyer and 'The Transition Handbook From Oil Dependency to Local Resilience' by Rob Hopkins.

5 For a full list of these documents see Section 1.2 Site Selection for Field Research. Analysis of each Core

Recommendation excluded the Planning Act, 1990, as it was assumed that these Core Recommendations would be allowed under the Planning Act.
} 


\section{(4) What is the economic cost associated with implementing the recommendation versus a regular Plan of Subdivision?}

Each recommendation will be evaluated or its cost economically to a developer through pro forma analysis. In order to obtain relevant assumptions for the pro forma analysis this MRP sought input from professionals with Whitby-specific or accessibility-specific experience, and supplementing this with information from two widely-used industry costing reports.

\section{Professionals}

- Personal communication with Home Builder/Developer (HB/D) with over 20 years' experience building homes in Whitby as President of his company (March 12, 2015).

- Personal communication with Planning Consultant \#1 (PC1), a Registered Professional Planner (RPP) with over 30 years working in Durham Region and the GTA (March 5, 2015).

- Personal communication with Planning Consultant \#2 (PC2), a Registered Professional Planner (RPP) with over 40 years working in the home building industry and as a planning consultant in the GTA (March 17, 2015).

- Personal communication with one of Ontario's leading Accessibility Consultants (AC), who is also a Registered Professional Planner (RPP) and who has a decade of experience working in Southern Ontario (March 19, 2015).

\section{Reports}

- "Altus Cost Guide", 2015 (which provides for GTA specific estimates for the cost of construction); and

- "Costs for Pedestrian and Bicyclist Infrastructure Improvements: A Resource for Researchers, Engineers, Planners and the General Public" (Bushell, Poole, Zegeer \& Roderiguez, 2013). This was a report by the UNC Highway Safety Research Centre for the Federal Highway Administration in the United States. It is a widely cited study that examined 77 pedestrian/bicycling facilities using more than 1,700 cost estimates. The prices were adjusted for inflation and converted to CAD. To see a full list of assumptions used in the pro forma analysis, please see Appendices 1B to 17B.

For each pro forma analysis, the 'Return on Equity' (ROE) was calculated in order to compare the financial feasibility of the different Core Recommendations to the Base Case Scenario. ROE is calculated in the following manner:

$$
\frac{\text { Revenues }- \text { Costs }}{\text { Equity invested in project }}=\text { ROE }
$$

*Costs include hard, soft and land costs. 


\subsection{BASE CASE CREATION}

In order to create a base case that was representative of a typical subdivision in Whitby,

Ontario, and provided the most accurate assumptions about project costs, the pro forma analysis used in this report is based on a site with the following parameters:

- $\quad$ Site Size: 20 acres

- Developable Land: 19 acres (-5\% for Parkland Dedication)

- Housing Type: 1500 sqft Townhouses on $6 \mathrm{~m} \times 28 \mathrm{~m}$ lots

- On level greenfield land already designated 'Living Area' by the Region of Durham's Official Plan, 2013

- Street Layout: Shown in Illustration 1: Base Case Scenario.

There are site specific characteristics that cannot be represented through a base case pro forma (such as diversity of housing types, lot sizes, site conditions, etc.), and would inevitably have an effect on the Return on Equity (ROE) of the project. This variance however, is expected to be minimal unless it is a particularly complex site. This base case scenario allows developers, planning consultants and municipal staff to identify how implementing dementia-friendly design into a subdivision might affect the bottom line, in order to test their financial feasibility and provide insight on implementation.

\subsection{LIMITATIONS}

The methods used for the MRP face the following limitations:

- The Base Case Scenario created for the pro forma analysis was an example of what a Plan of Subdivision might possibly look like in Whitby and is not tied to a specific site. It was to demonstrate a typical site that could be used to draw initial conclusions about the feasibility of implementing the Core Recommendations. For that reason, if this model is tested on a site specific basis, the findings might be different, but they are likely to be close to the findings of this report.

- The prices obtained for the financial feasibility analysis may be quoted differently by different stakeholders, depending on the quality of buildings, previously established relationships with suppliers and labor as well as changing market conditions. That being said, the numbers are likely to be in a range that is close to the numbers assumed by this report.

- The 17 Core Recommendations selected for analysis in this report represent the most current findings from the literature in regards to adapting the environment to be more safe, legible, comfortable, accessible, distinct and familiar. There is still more research to be done on this topic, but it was beyond the scope of this paper to accomplish. 
- Unfortunately, the author was limited to papers written in English, which may have limited the number of sources.

The next chapter will examine each of the 17 Core Recommendations individually and will conclude with preliminary recommendations on how to implement each. 


\section{CHAPTER 3: INVESTIGATION OF CORE RECOMMENDATIONS \#1 - \#17}

This section investigates each of the 17 Core Recommendations using the Methodology as described in Chapter 2, in order to assess the impact of each individual Core Recommendation on the Base Case Scenario's Return on Equity (ROE).

\section{1- MIXED USE AREAS}

\section{Description}

Burton \& Mitchell (2006) note that persons with dementia are far more restricted in their movements in the outdoor environment than healthy participants, as they are limited by how far they can walk (most people with dementia are no longer able to drive and cannot use public transport without supervision from a carer) (p.34). They describe this recommendation as providing within a neighbourhood, "a mix of uses, including plenty of services and facilities and open space," (p.138). They also list a number of facilities and amenities that should ideally be located no further than $125 \mathrm{~m}$ (public telephone and post box) from a person with dementia's front door (p.98). In addition, the authors mention that the essential services and facilities (like a post office, food store, bank, doctor's office, green space, public toilets, seating, bus stop) should not be more than 500m, and secondary services and facilities (library, dentist, optician, place of worship, recreation facility) should not be more than $800 \mathrm{~m}$ away (p. 98-99).

Another reason to be close to amenities is the fact that at 70 year old person has about half the strength and stamina of a person in their 20 s, not to mention that men are typically twice as strong as women (meaning a man in his 20 s in four times as strong as a woman in her $70 \mathrm{~s}$ ) (p.24). Perhaps most importantly however, was the finding that visiting a shop was the most common destination for both control and participants with dementia (p.34). Persons with dementia prefer less socially demanding situations, and shopping provides the perfect balance of helping them to retain independence and not be forced into a situation where they may not know how to act (p.34). 


\section{Literature Review}

Mixed use areas were mentioned in 9 out of the 12 articles used for this MRP, one of the most frequently mentioned Core Recommendations. The primary reason for this is the phenomenon of the 'shrinking world' which was identified by Duggan et al. (2008). Once a person with dementia loses their driver's license, often their radius of movement (often calculated from their place of residence) shrinks considerably. Duggan et al. (2008) found that not only does one's physical environment shrink, but so too does their social network. Persons with dementia are then limited to what they can reach by public transport or on foot. ${ }^{6}$ Perhaps the most important study to explain the massive impact of having mixed use areas is research that was completed in Tel-Aviv, Israel. The study tracked 41 persons with mild cases of dementia, mild cognitive impairment $(\mathrm{MCI})^{7}$ and healthy persons aged 64 - 90 using GPS trackers to see how far they venture from their place of residence (Shoval et al., 2011, p. 849). While the researchers note that another study with more participants should be completed in several developed countries to be certain of results, their preliminary findings showed:

1. When compared to the healthy group, those with mild dementia traveled significantly smaller distances in out of home activities. They also showed a 'smaller spatial range' as compared to those with MCI. (See Figure 3 below for a visual representation)

2. The differences between men and women within the groups, as well as differences in age showed varying spatial ranges.

3. Daily time pattern of activities for those with dementia varied the least and was the least modulated, suggesting they follow familiar routes, day in and day out.

4. In persons with dementia, there was also a change in the location of their activities. (p. 863)

\footnotetext{
6 While the importance of making public transport 'dementia-friendly' is also a crucial topic that needs to be investigated, it is beyond the scope of this paper.

7 Mild Cognitive Impairment differs from the symptoms of dementia, primarily in that the symptoms are not as severe and while they are at an increased risk, may not develop into Alzheimer's disease or other dementia symptoms. Shoval (2011) notes that there is some disagreement in the literature as to the exact definition of $\mathrm{MCl}$, however for the purposes of their experiment, those with $\mathrm{MCl}$ were defined as persons with a Mini-Mental State Examination (MMSE) score of between 26 and 30 (p. 854).
} 
Shoval et al. (2011) show that cognitive decline does have a significant impact on range of mobility for persons with mild dementia. Most importantly, they note the implication for design of neighbourhoods:

"The cognitive constraints on people's spatial activity must be recognized. For example, the closing of basic services such as food shops and doctors offices within a neighbourhood and the shifting of these services to adjacent locations can create considerable burdens on the population of elderly people with cognitive impairment. These findings highlight the need to keep as many essential functions as possible local in order to enable these populations to live within the community." (p. 864)

Figure 1 - Average of median distance travelled from home for three cognitive groups

860 Noam Shoval et al.
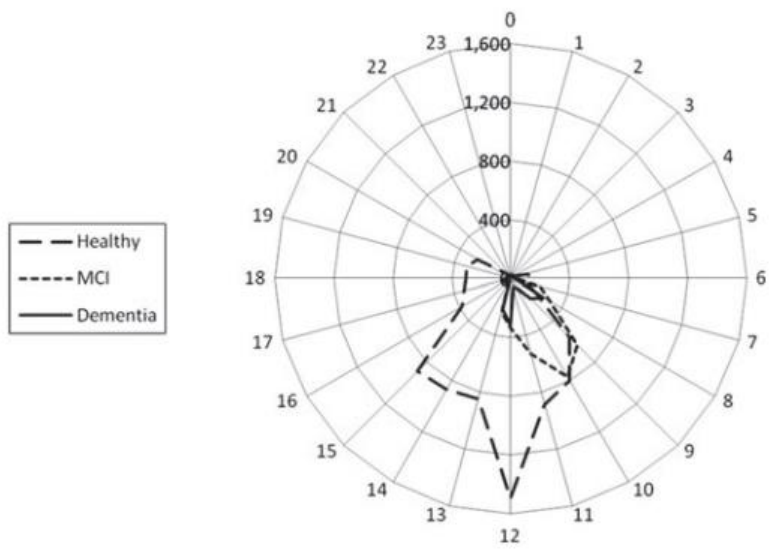

Figure 3. Average of median distance from home for three cognitive groups. Note: MCI: mild cognitive impairment.

This review of the literature combined with Burton \& Mitchell's (2006) study prove that the most beneficial land use to mix with residential in order to best serve persons with dementia and older persons in general, is retail uses. While ideally all of the services listed by Burton \& Mitchell (2006) should be located within an $800 \mathrm{~m}$ radius, establishing shops within the walking distance of people with dementia will probably be the most effective first step. 


\section{Planning Principles Literature}

\section{"The Image of the City", K. Lynch, 1960}

Through his classification of the modern city into five elements (paths, nodes, districts, landmarks and edges), Lynch (1960) began to define how these integral aspects of a city interacted with one another to varying effect. While he does not explicitly mention that mixed use areas are of benefit to people, he does take note of how quality paths and nodes have vibrant street life on them, which make them more legible and memorable than stretches or areas without activity (p.49-51). This is indication that case studies that mention the vibrant street life are the successful ones, and mixed use areas are the best way to facilitate this, by creating a critical mass of people and encouraging walking to destinations.

\section{Resilient City "Urban Design Principles'}

Mixed use areas encompass many of Resilient City's principles, including:

\section{Principle 1 - Density, Diversity and Mix}

This principle calls on urban planners to move away from single use zones that are only used for part of the day to mixed use zones that are more active at varying times. In addition, it encourages mixed use areas so a variety of amenities can be located close together and are "accessible to a diversity of users."

\section{Principle 2 - Pedestrians First}

This principle calls on planners to develop areas in such a way that it promotes active forms of transportation, especially walking. While installing features to make the environment better for pedestrians, people need something to walk to. Having areas with a mix of compatible uses (like residential and small format retail for example) are one of the best ways to do this.

\section{Principle 3 - Transit Supportive}

Having a mix of uses means that there will inherently be both more density than normal as well as more users of public space throughout the day, instead of at certain times. Both of these factors make the case for increased transit service, and it might in turn, encourage more people to use it. 
Principle 4 - Place-making

Mixed use spaces are in a sense, the opposite of urban sprawl. Urban sprawl (which is common is Whitby) lacks meaningful and symbolic places within a subdivision neighbourhood, meaning that these places are likely to lack a sense of identity. Mixed use spaces on the other hand, have vibrant public realms and a critical mass of uses that supports local destinations.

Principle 5 - Complete Communities

Mixed use areas enable the idea that residential areas should be within $500 \mathrm{~m}$ of stores and other services to fulfill their daily needs.

Principle 8 - Local Sources

The push to cultivate food from closer to one's home could be achieved by protecting the land supposed to be used for urban sprawl and encouraging mixed use, slightly denser areas instead.

Principle 11 - Resilient Operations

The fact is that it is more difficult to service sprawling areas, by virtue of the length of underground servicing pipes required to serve so few people. 


\section{Current Planning Frameworks}

\section{Provincial Policy Statement, 2014}

Section 1.1 Managing and Directing Land Use to Achieve Efficient and Resilient Development and

Land Use Patterns states that 'Healthy, liveable and safe communities are sustained by:"

\section{Section}

b) accommodating an appropriate range and mix of residential (including second units, affordable housing and housing for older persons), employment (including industrial and commercial), institutional (including places of worship, cemeteries and long-term care homes), recreation, park and open space, and other uses to meet long-term needs;

c) avoiding development and land use patterns which may cause environmental or public health and safety concerns;
How does Recommendation \#1 - Mixed Use Areas Embody the section?

The PPS is directly calling for municipalities to zone areas so that a mix of land uses can be achieved.
According to the report published in 2014 by the Chief Medical Officers for Health from around the GTA ('Improving Health by Design') the current model of the car dependant suburb is making our population physically and mentally sick, not to mention incurring billions in healthcare costs. Creating mixed use neighbourhoods encourages people to walk to do errands, which the authors note is much healthier than driving. In addition, dementia will soon become one of the greatest public health problems Canada has ever faced, as our population gets older. In order to facilitate independence and remaining in community for as long as possible, it is imperative that we design neighbourhoods to be accessible to persons throughout the life course.

e) promoting cost-effective development patterns and standards to minimize land consumption and servicing costs;

f) improving accessibility for persons with disabilities and older persons by identifying, preventing and removing land use barriers which restrict their full participation in society;
Building mixed use areas will encourage more compact living areas, therefore decreasing lot sizes and increasing the number of houses served per metre of underground servicing.

Building mixed use areas in Whitby, and encouraging residential uses to be close (preferably $500 \mathrm{~m}$ at maximum) to amenities greatly reduces the biggest barrier to participating and remaining active in society once one has lost their driver's license - distance.

In addition, Section 1.5.1 states "Healthy, active communities should be promoted by:

a) planning public streets, spaces and facilities to be safe, meet the needs of pedestrians, foster social interaction and facilitate active transportation and community connectivity; 
b) planning and providing for a full range and equitable distribution of publicly-accessible built and natural settings for recreation, including facilities, parklands, public spaces, open space areas, trails and linkages, and, where practical, water-based resources"

Mixed use areas are one of the best ways to foster social interaction be means of a critical mass, and of encouraging people to walk to destinations.

Lastly, Section 1.8.1. states: "Planning authorities shall support energy conservation and efficiency, improved air quality, reduced greenhouse gas emissions, and climate change adaptation through land use and development patterns which: a) promote compact form and a structure of nodes and corridors; $b$ ) promote the use of active transportation and transit in and between residential, employment (including commercial and industrial) and institutional uses and other areas." Mixed use areas promote compact form and encourage active transportation more so than single use areas (which are common in Whitby).

Town of Whitby Accessibility Standards, 2005

Mixed use areas are not mentioned in this document.

\section{How can this be measured?}

In order to understand the cost to a developer of building a subdivision with a mix of uses, the base case pro forma of a subdivision in Whitby has been modified to include a 4-storey building with retail uses on the main floor and residential condominiums on the upper three floors, and then compared to the Return on Equity for a subdivision with $100 \%$ Townhouses.

\section{How can this be economically quantified?}

It was discovered, using assumptions from the Altus Cost Guide, 2015 as well as personal communication with an experienced developer (HB/D) in Whitby that the construction of a mixed use building and subdivision (as opposed to solely subdivision) in Whitby would decrease the possible Return on Equity by $26.93 \%$, to an ROE that sits at $19.48 \%$. This is still well within the acceptable rate of return as stated by key informants as well as Peiser \& Hamilton (2012, p.103) (See Appendix 2A and 2B for the full assumptions and pro forma results). 
Table 3: ROE Comparison (Mixed Use Areas)

\begin{tabular}{|l|c|}
\multicolumn{1}{|c|}{ Development Type } & Return on Equity \\
\hline $\begin{array}{l}\text { 100\% Townhouse-style Subdivision } \\
\text { s0\% Townhouse-style Subdivision with a } 4- \\
\text { storey mixed use building covering the } \\
\text { remaining } 20 \%\end{array}$ & $46.45 \%$ \\
\hline
\end{tabular}

\section{CONCLUSION}

While Burton \& Mitchell (2006) encourage a variety of uses to be within $800 \mathrm{~m}$ of a person with dementia's home, the current norms for developing subdivisions in Whitby make this a difficult task. The cost of incorporating a mixed use building into a subdivision compared with a $100 \%$ residential subdivision did have a substantial effect on the ROE of the project, however, the rate of return is well within the desired range. This means that the Town and/or Region could write it into the new harmonized Zoning By-law or Official Plan, with the knowledge that there is a decreased risk of loss of investment in the Town.

The Town could also offer some form of incentive to encourage developers to build mixed-use buildings, such as a development charge waiver, parkland reduction, or parking requirement reduction. These incentives are commonly used by municipalities on a site-by-site basis, and could be combined into a Community Improvement Plan (See Appendix 18 for a full explanation of this commonly used planning tool).

Table 4: Incentives Summary (Mixed Use Areas)

\begin{tabular}{|l|l|}
\multicolumn{1}{|c|}{ Incentive } & Change in ROE \\
\hline Development Charge Waiver (5\% reduction) & $21.34 \%(+1.86 \%)$ \\
\hline Parking Requirement Reduction (25\% reduction) & $22.53 \%(+3.05 \%)$ \\
\hline ALL & $23.73 \%(+4.25 \%)$ \\
\hline
\end{tabular}

If one combined a Development Charge Reduction of $5 \%$, and provided a $25 \%$ Parking Requirement Reduction, the project would reach an ROE of $23.73 \%$, which is much better than the ideal range. (See Appendices 2.1A through 2.3A and 2.1B through 2.3B for the full assumptions and 
pro forma analysis). The point here is to demonstrate that residential neighbourhoods can be built so that they are actually walkable, by providing retail within a corner of the subdivision through a combination of legislative changes, and if that does not work, incentives can always be offered.

\section{2 - WIDE, SMOOTH FOOTWAYS}

\section{Description}

According to Burton \& Mitchell (2006) "Footways should be wide and plain, smooth, level, nonslip and non-reflective paving," (p.127). The authors also note that foot ways should be at least $2 \mathrm{~m}$ wide, to allow those in wheelchairs safely pass one another. Another reason is that many people with dementia experience issues with depth perception and therefore "cannot always interpret the intentions of oncoming pedestrians," and since they lack the agility to get out of the way, risk falling over. Wider sidewalks give more space and lessen this risk (p.120).

In addition, the added width allows the pedestrian to be farther from the road. The authors note that the footways should not be shared with cyclists and should be separated from them by landscaped space (p.126). Lastly, the authors advise planting evergreens or trees with small leaves along footways, as other types of trees have large leaves that get slippery (p.127). The reasons for these measures are to reduce the risk of falls for people with dementia (as well as other older persons). As many as $1 / 3$ of persons over 65 and $1 / 2$ of persons over 85 years old will fall once a year, and falling can lead a person to avoid going outdoors due to the fear of falling again (p.120), which could lead to isolation and increase loneliness.

\section{Literature Review}

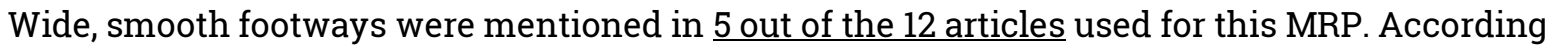
to the literature, the qualities of a pathway, such as its width, its relationship to the road, and the materials used can pose as barriers for those with ADRD. As Brorsson et al. (2013) note, their study of observing people with ADRD on a trip to the grocery store, proved earlier findings including 
difficulties associated with distinguishing a pedestrian path from a road when not physically separated and in observing changes in levels (p. 298). This means that flushing the road to a sidewalk might be confusing for those with dementia, in addition to sudden changes in level.

A way to mitigate this could be to put reflective markers on the ground, or to paint the side of a curb in a contrasting tone. CMHC (2014, p.38, 19) and Mitchell et al. $(2003$, p.627) summarize how pathways should be designed based on interior design literature for senior's care homes. They offer a few a parameters, including widening the sidewalk to fit two people plus a wheelchair, ensuring it is a consistent tone, is flat, non-slip and non-reflective, in addition to being well-maintained. This maintenance was further described as using materials that are unlikely to shift as a result of time or wear, and not planting trees with large deciduous leaves near paths to prevent making the pathway slippery with leaves (Mitchell et al. 2003, p.627). As Blackman et al. (2003) notes, "Plain, smooth, level, non-slip and non-reflective paving is likely to be the most effective surfacing for older people in general and people with dementia in particular," (p.365). Lastly, this emphasis on wider sidewalks was found by Brorsson et al. (2014, p.12) and Blackman et al. (2007, p.819-821) to make persons with dementia feel more at ease in the outdoor environment, and combat issues associated with car and pedestrian traffic congestion.

\section{Planning Principles Literature}

\section{"The Image of the City", K. Lynch, 1960}

Paths are one of Lynch's five symbols that make up a city and make up the routes by which people move around the city. Paths were identified in Lynch's interviews as "the predominant city elements." Lynch's work looked at several paths within cities, which all had varying characteristics (such as width, uses located along the path, the quality of the small landmarks along it, pedestrian or car congestion, what the path led to etc.) and these characteristics affected the legibility of the path in some way. This variance in paths helped people to understand where they were in the city, such as in a specific district or area. For example, participants noted that people were generally 
more comfortable taking wider streets as it was perceived to be a main street and more safe, automatically $(p .50,51)$. This may be a reason to build wider sidewalks, but the most important takeaway is that the design of paths and its features matter for legibility of space.

\section{Resilient City "Urban Design Principles'}

Wide, smooth footways could contribute to achieving Resilient City's first principle "Density, Diversity and Mix" as well as the second principle "Pedestrians First." The first principle encourages mixed use areas so a variety of amenities can be located close together and are "accessible to a diversity of users." The second principle states that walking should be prioritized "as the preferred mode of travel and as a defining component of a healthy quality of life," but most importantly, defines a pedestrian as including persons with disabilities. Environments that promote healthy active living for all groups, including the more vulnerable, make for sustainable cities where people can live, work learn and play, and wider more accessible sidewalks are a small step towards that. 
Current Planning Frameworks

\begin{tabular}{|c|c|c|c|}
\hline Jurisdiction & Policy & $\begin{array}{l}\text { Applicable } \\
\text { Sections* }\end{array}$ & Summary \\
\hline \multirow[t]{2}{*}{$\begin{array}{l}\text { Province of } \\
\text { Ontario }\end{array}$} & $\begin{array}{l}\text { Provincial Policy } \\
\text { Statement }\end{array}$ & $\begin{array}{l}1.1 \\
1.5 .1 \\
4.6\end{array}$ & $\begin{array}{l}\text { Not explicitly mentioned, but PPS points to the } \\
\text { need to remove barriers for persons with } \\
\text { disabilities as well as older persons. Narrow } \\
\text { footpaths as well as traditional sidewalks being } \\
\text { perceived as a potential tripping hazard have been } \\
\text { identified as barriers by persons with dementia in } \\
\text { the literature. Removing these barriers by building } \\
\text { wider sidewalks with non-slip surfacing for } \\
\text { example, is a step toward fuller participation for } \\
\text { those with dementia into society. }\end{array}$ \\
\hline & $\begin{array}{l}\text { Growth Plan for } \\
\text { the Greater } \\
\text { Golden } \\
\text { Horseshoe }\end{array}$ & $\begin{array}{l}2.2 .2 .1 \mathrm{~d}) \\
2.2 .7 \\
2.22\end{array}$ & $\begin{array}{l}\text { Not explicitly mentioned, but GP instructs that } \\
\text { greenfield development shall be compact, with } \\
\text { urban form and design that supports walking and } \\
\text { creates high quality public space. Wide, smooth } \\
\text { footpaths will encourage walking for those with } \\
\text { dementia and may make the pedestrian } \\
\text { environment more inviting to others. }\end{array}$ \\
\hline $\begin{array}{l}\text { Region of } \\
\text { Durham }\end{array}$ & Official Plan & $\begin{array}{l}2.2 .5 \\
2.3 .5 \\
2.2 .10 \\
8.1 .4 \\
8.1 .10 \\
8.3 .10 \\
8.2 .1 \\
8 C .1 .6 \\
8 C .2 .9 \\
\end{array}$ & $\begin{array}{l}\text { Not explicitly mentioned, but the Regional OP } \\
\text { seeks to encourage area municipalities to create } \\
\text { urban design guidelines. Development is to take } \\
\text { aesthetics into account, promote a sense of } \\
\text { community, encourage pedestrian oriented } \\
\text { environments, and promote compact urban form } \\
\text { that encourages active transit. Wide, smooth } \\
\text { sidewalks can help fulfill these directions. }\end{array}$ \\
\hline \multirow[t]{4}{*}{$\begin{array}{l}\text { Town of } \\
\text { Whitby }\end{array}$} & Official Plan & $\begin{array}{l}8.1 .3 .7 .10 \\
10.1 .13 .4\end{array}$ & $\begin{array}{l}\text { Not explicitly mentioned, but the Whitby OP seeks } \\
\text { to encourage pedestrian facilities that improve } \\
\text { accessibility for persons with disabilities. Wide, } \\
\text { smooth sidewalks is one way to fulfill this } \\
\text { direction. }\end{array}$ \\
\hline & $\begin{array}{l}\text { Zoning By-law } \\
2585\end{array}$ & $\mathrm{n} / \mathrm{a}$ & \\
\hline & $\begin{array}{l}\text { Engineering } \\
\text { Standards }\end{array}$ & C 5.0 & $\begin{array}{l}\text { Sidewalk width is not specified in the Engineering } \\
\text { Standards, however would be a good spot to put it. } \\
\text { Right now they have standards for concrete } \\
\text { sidewalks and pavers. }\end{array}$ \\
\hline & $\begin{array}{l}\text { Landscape Plan } \\
\text { Guidelines }\end{array}$ & $\begin{array}{l}4.3 \\
\text { Appendix C }\end{array}$ & $\begin{array}{l}\text { Sidewalk width should be } 1.5 \text { to } 2 \mathrm{~m} \text { and pedestrian } \\
\text { walkways are required to provide accessible, direct, } \\
\text { safe, continuous and clearly defined access from } \\
\text { public sidewalks, parking areas and transit stops to } \\
\text { building entrances. }\end{array}$ \\
\hline
\end{tabular}

*For a full list of the exact sections detailed in this Table, please see Appendix 19 - Current Planning Frameworks List. 
Town of Whitby Accessibility Standards, 2005

Section 4.1.4 details specifics about how to build accessible routes, including that they must be at least $1.83 \mathrm{~m}$ wide (in order to allow for those in wheelchairs to safely pass one another and turn around). Section 4.4 .15 states that putting complex patterns on floors can add visual confusion to a space and, thus caution against it. Section 4.3.14 gets more specific and cautions against the following:

- Using sidewalk pavers that might move due to freezing and unfreezing and become a tripping hazard; and

- Incorporating plants that drop large seed pods, which can pose a barrier for those in a wheelchair or using a mobility aid and cause slipping.

This supports earlier findings from Burton \& Mitchell (2006) and other literature. Unfortunately, these accessible routes are only enforced within a public facility setting, and even then, only required to get to and from important destinations within the facility (such as from the accessible parking spot to the front desk, but not to the equipment room for example).

\section{How can this be measured?}

This can be measured by figuring out the cost of treating sidewalks so that they are wider than the typical sidewalk width of $1.5 \mathrm{~m}$ as well as treating them to be non-slip. According to the established Home Builder/Developer in Whitby, a 1.5m wide cement sidewalk costs $\$ 150$ per linear metre, and therefore widening the sidewalk to $2 \mathrm{~m}$ would cost $\$ 200$ per linear metre. According to personal communication from both the planning consultants indicated that using 'large groove paving' would not only be non-slip, but would also be less likely to cause tripping. Upon advice from the Accessibility Consultant, so long as the grooves are no more than $13 \mathrm{~mm}$ deep, the sidewalk meets AODA specifications. In addition, PC2 said this type of pavement would perform well in a Canadian climate and not be as effected by the freezing and thawing - remaining flat. It would cost $\$ 160$ per linear metre of $2 \mathrm{~m}$ wide sidewalk. 


\section{How can this be economically quantified?}

This can be economically quantified by changing the assumption on the base case pro forma to see what the difference would be on the ROE. Please see Table 6 below for a summary of the findings and Appendix 3A and 3B for the full assumptions list and pro forma.

Table 6: ROE Comparison (Wide, Smooth Footways)

\begin{tabular}{|l|l|l|}
\hline Sidewalk Type & Cost per linear metre & ROE \\
\hline $1.5 \mathrm{~m}$ wide cement & $\$ 150$ & $46.45 \%$ \\
\hline Non-slip and $2 \mathrm{~m}$ wide & $\$ 160$ & $46.41 \%$ \\
\hline
\end{tabular}

\section{CONCLUSION}

It is evident that wider sidewalks with non-slip paving benefit a majority of people in society, including those with dementia. While this type of paving costs about $\$ 10$ more per linear metre, the change in ROE is negligible at $0.04 \%$. This means that the Town could update their engineering standards to require this type of paving.

\section{3 - FREQUENT ROAD CROSSINGS}

\section{Description}

According to Burton \& Mitchell (2006) it is necessary to have safe and frequent crossing to facilitate the movement of those with dementia. The more routes and road crossings mean a more walkable neighbourhood, meaning more accessible ways for arriving at a particular destination. The study found that signalized intersections, with audible cues (at a low pitch) and a visual countdown was the best way to make a busy intersection safe (p.125). Some participants were fearful of zebra crossings (known as crosswalks in Canada) as they were not able to tell if vehicles were going to stop (p.126).

\section{Literature Review}

Frequent road crossings were mentioned in 7 out of the 12 articles used for this MRP. A crossing point is defined as a place where people find it natural to cross the street or are encouraged to do so by visual cues (Brorsson et al. 2014, p.12). Sheehan et al. (2006) found that both 
control and participants with dementia "showed confidence in crossing roads," and did not have any incidents (p.277). Blackman et al. (2007) echoed this by saying the most participants "had no trouble crossing the street," however, they showed preference for pedestrian areas, which might be perceived as safer (p.820). That being said, several other studies found opposing observations.

Brittain et al. (2010) discuss the rapid pace of traffic and the crossing of streets at complicated intersections as a way of life for most people that takes for granted our ability to navigate it. The assumption that it is good for everyone can become "a source of stress and can disenfranchise or put at risk those unwilling or unable to meet such demands," (p.274). Brorsson et al. (2013) in their study of observing those with dementia as they went on a trip to the grocery store, witnessed several critical incidents when crossing the road (some of which the observer had to intervene in the name of safety) and found that the majority of participants became very stressed when crossing the road. In addition to not being certain if drivers and cyclists were to stop, the amount of noise made it hard to discern which sounds to pay attention to and caused mental fatigue (p.296). The authors concluded that walking through one's neighbourhood is a complex activity, which requires them to discern the relevant information to pay attention to in space, as well as navigate changing conditions. They also found that one must "perform two or more motor and cognitive activities simultaneously... [which makes it] even more difficult for people with dementia," (p.298).

Brorsson et al. (2014) continued to research how those with dementia utilize road crossings, specifically zebra crossings. They found that crossing the street requires 'dual task performance' and those who have dementia already experience difficulty with this. The ability to respond to a multitude of layers of information immediately is hampered in those with dementia, meaning they are more likely to experience a critical incident when crossing the road (p.10). Blackman et al. (2007) echoed this, finding that the lower their Mini-Mental State Examination score, the more likely they are they were to act unsafely crossing the street. It could mean that focusing on the task of getting to a particular location might have distracted them from the danger of road traffic (p.820). 
Participants tended to trust their own judgment when crossing a street but mentioned that having a traffic light was a good reminder of the proper place to cross the street (Brorsson et al., 2014, p.10). Mitchell et al. (2003) note that audible crossing signals, if they are familiar experiences, can also aid in crossing the street (p.625).

\section{Planning Principles Literature}

\section{The Image of the City", K. Lynch, 1960}

Road crossings, where a number of paths meet form one of Lynch's five elements - nodes. Lynch (1960) describes nodes as "strategic foci" within the city landscape, as this is where "people heighten their attention....and perceive nearby elements with more than normal clarity," (p.72, 73). The reason for this is that decisions have to be made at junctions, and humans respond instinctively by being on alert. This action was repeated so often in his interviews that Lynch concluded that "elements located at junctions may automatically be assumed to derive special prominence from their location," (p.73). In addition, when people were asked about a point on a habitual trip when they arrived in downtown Boston, they always mentioned a junction of transportation - be it an exit off a highway, a traffic circle or railroad station (p.73). The fact that participants had a heightened awareness at crosswalks means that humans are already taking in extra information than while walking along a path for example. That extra information could become confusing for someone with dementia, and that is why it is necessary to put extra safety measures in place for this vulnerable group.

\section{Resilient City "Urban Design Principles'}

Principle 2 - Pedestrians First

This principle calls on planners to develop areas in such a way that it promotes active forms of transportation, especially walking. While installing features to make the environment better for pedestrians, people need something to walk to. Providing safe, frequent crossings and increasingly connectivity is one of the best ways to do this. This principle states that walking should be 
prioritized "as the preferred mode of travel and as a defining component of a healthy quality of life,"

but most importantly, defines a pedestrian as including persons with disabilities. Environments

that promote healthy active living for all groups, including the more vulnerable, make for

sustainable cities where people can live, work learn and play, and providing safe frequent crossings

that can help those with dementia is a small step towards that.

Principle 5 - Complete Communities

Connectivity is key to complete communities, and providing frequent, safe pedestrian oriented

crossings is one way to achieve this.

\begin{tabular}{|c|c|c|c|}
\hline \multicolumn{4}{|c|}{ Table 7: Frequent Road Crossings } \\
\hline Jurisdiction & Policy & $\begin{array}{l}\text { Applicable } \\
\text { Sections* }\end{array}$ & Summary \\
\hline \multirow[t]{2}{*}{$\begin{array}{l}\text { Province of } \\
\text { Ontario }\end{array}$} & $\begin{array}{l}\text { Provincial Policy } \\
\text { Statement }\end{array}$ & $\begin{array}{l}1.1 \\
1.5 .1 \\
4.6\end{array}$ & $\begin{array}{l}\text { Not explicitly mentioned, but PPS points to the } \\
\text { need to remove barriers for persons with } \\
\text { disabilities as well as older persons. There are } \\
\text { features of typical suburban environments one } \\
\text { could argue that block the rights of someone with } \\
\text { dementia to continue to be able to access their } \\
\text { neighbourhood, including a lack of connectivity } \\
\text { and safety measures. Incorporating safety } \\
\text { measures into street crossings, as well as } \\
\text { including more of them, which enables walkability } \\
\text { and street connections, are steps toward fuller } \\
\text { participation for those with dementia into society. }\end{array}$ \\
\hline & $\begin{array}{l}\text { Growth Plan for } \\
\text { the Greater } \\
\text { Golden } \\
\text { Horseshoe }\end{array}$ & $\begin{array}{l}2.2 .2 .1 \mathrm{~d}) \\
2.2 .7 \\
2.22\end{array}$ & $\begin{array}{l}\text { Not explicitly mentioned, but GP instructs that } \\
\text { greenfield development shall be compact, with } \\
\text { urban form and design that supports walking and } \\
\text { creates high quality public space. Frequent } \\
\text { Crossings will encourage walking for those with } \\
\text { dementia and may make the pedestrian } \\
\text { environment more inviting to others. }\end{array}$ \\
\hline $\begin{array}{l}\text { Region of } \\
\text { Durham }\end{array}$ & Official Plan & $\begin{array}{l}2.2 .10 \\
8.1 .4 \\
8.1 .10 \\
8.3 .10 \\
8.2 .1 \\
8 c .1 .6 \\
8 C .2 .9\end{array}$ & $\begin{array}{l}\text { Not explicitly mentioned, but the Regional OP } \\
\text { seeks to encourage area municipalities to create } \\
\text { urban design guidelines. Development is to take } \\
\text { aesthetics into account, promote a sense of } \\
\text { community, encourage pedestrian oriented } \\
\text { environments, and promote compact urban form } \\
\text { that encourages active transit. Frequent road } \\
\text { crossings and increased safety measures can help } \\
\text { fulfill these directions. }\end{array}$ \\
\hline $\begin{array}{l}\text { Town of } \\
\text { Whitby }\end{array}$ & Official Plan & $\begin{array}{l}8 \cdot 1 \cdot 3 \cdot 1.7 \\
8 \cdot 1 \cdot 3 \cdot 7 \cdot 10 \\
10.1 \cdot 13.4\end{array}$ & $\begin{array}{l}\text { Not explicitly mentioned, but the Whitby OP seeks } \\
\text { to encourage pedestrian facilities that improve } \\
\text { accessibility for persons with disabilities. The OP }\end{array}$ \\
\hline
\end{tabular}




\begin{tabular}{|l|l|l|l|}
\hline & & $\begin{array}{l}\text { also encourages a grid orientated street network } \\
\text { which in turn encourages more road crossings. } \\
\text { Frequent road crossings and increased safety } \\
\text { measures are one way to fulfill these directions. }\end{array}$ \\
\cline { 2 - 4 } & $\begin{array}{l}\text { Zoning By-law } \\
2585\end{array}$ & $\mathrm{n} / \mathrm{a}$ & C.3.0 \\
\cline { 2 - 5 } & $\begin{array}{l}\text { Engineering } \\
\text { Standards }\end{array}$ & $\begin{array}{l}\text { Details the Geometric Design Criteria for } \\
\text { intersections. The Region is usually responsible for } \\
\text { the installation of traffic signals - and their } \\
\text { specifications are not included in this document. } \\
\text { Nor are the specifications for crosswalks. }\end{array}$ \\
\cline { 2 - 4 } & $\begin{array}{l}\text { Landscape Plan } \\
\text { Guidelines }\end{array}$ & $\mathrm{n} / \mathrm{a}$ & \\
\hline
\end{tabular}

*For a full list of the exact sections detailed in this Table, please see Appendix 19 - Current Planning Frameworks List

Town of Whitby Accessibility Standards, 2005

The only mention of accessibility measures that should be put in place at intersections in

outlined in Section 4.1.10. It details specifics about how to build a ramp that is accessible for both those in wheelchairs/with mobility aids, as well as for those who are visually impaired. Ramps will however be quantified by \#7 - Marked Level Changes Section.

\section{How can this be measured?}

Safe intersections can be measured in a variety of different ways. For the purpose of this report, the Base Case Subdivision has been drawn (Illustration 1 - Base Case Scenario) and the internal (within the subdivision) and external (abutting an arterial or collector road) have been counted. Upon discussion with PC2, it was indicated that usually the cost of intersection signalization (for the external intersections) typically comes out of the Capital Works budget from the Town of Whitby. That being said, unless the situation warrants it, add-ons like APS may not be included, and that is why it is included on the developer's pro forma instead, at a cost of $\$ 10,000$ per intersection. For internal intersections, the treatment is of high-visibility painted zebra crossings, costing $\$ 15,975$ per 4 way stop. One intersection, near the park where the most traffic is likely to occur, will include a pedestrian crossing with a flashing beacon, Audible Pedestrian Signal, Pedestrian Signal and striped crosswalk for a total of $\$ 10,661$ per intersection.

\section{How can this be economically quantified?}

This can be economically quantified by changing the assumption on the base case pro forma to see what the difference would be on the ROE. In order to figure out the cost per intersection, the 
base case has been sketched out to understand how many internal intersections (within the development and less likely to see much traffic) and external intersections (connections to arterial or collector roads). Please see Table 8 and 9 below for a summary of these findings. See Appendix 4A and 4B for the full assumptions and pro forma.

Table 8: Calculations for Intersection Treatments

\begin{tabular}{|l|c|c|}
\multicolumn{1}{c|}{ Treatment } & $\begin{array}{c}\# \text { of } \\
\text { intersections }\end{array}$ & $\begin{array}{c}\text { Cost per intersection } \\
\text { Internal Intersection (Pedestrian Crossing + Striped) }\end{array}$ \\
\hline Internal Crossing (High Visibility Crossing) & 1 & $\$ 10,661$ \\
\hline External Intersections & 3 & $\$ 15,975$ \\
\hline TOTAL: & & $\$ 10,000$ \\
\hline
\end{tabular}

Table 9: ROE Comparison (Frequent Road Crossings)

\begin{tabular}{|l|l|}
\hline Base Case & ROE \\
\hline Base Case + Frequent Road Crossings & $46.45 \%$ \\
\hline
\end{tabular}

\section{CONCLUSION}

In conclusion, it is evident that more frequent, accessible and safe crossings benefit a majority of people in society, including those with dementia. The change in ROE was negligible at $0.25 \%$. This means that the Town could update their engineering standards to require these types of treatments, have it be strongly suggested by Staff through the pre-consultation to draft plan stages, or have it added to the Landscape Design of Site Plan and Plan of Subdivision Guidelines.

\section{4 - CLEAR SIGNS}

\section{Description}

Burton \& Mitchell (2006) highlight the importance of signs as a way to help persons with dementia find their way. They highlight light background signs with dark lettering that are simple and unembellished (p.75). This is to accommodate those with colour agnosia, a visual impairment often experienced by older persons and aggravated by dementia (p.25-26). Burton \& Mitchell (2006) 
draw from Barker and Fraser's 1999 Guide on inclusive signage and note other parameters based on their study:

- Signs should have non-glare and non-reflective coating;

- Directional signs should be located at wayfinding decision points on posts, like at road junctions;

- Signs posted flush to the wall help reduce clutter;

- 'You are Here' signs and maps may be good for people who are new to the area, but are nearly impossible for people with dementia to use. (p.75)

\section{Literature Review}

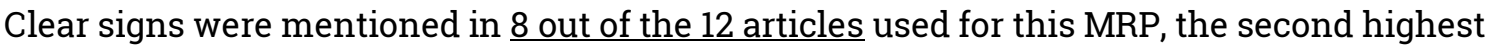
frequency out of the 17 Core Recommendations. Simple, explicit, clear, precise and easy to read signs were deemed to be the best, with most literature recommending plain signs with a white (or light) background and black (or dark) lettering and at a height that is visible, even to those who use mobility devices or walk hunched over (Blackman et al., 2003, p.363, Mitchell et al. 2003, p.623, CMHC, 2014, p.19, 29). The signs and physical landmarks were used "as a way of mediating between themselves and the outside environment, enabling them to carry on," as well as used participants to find their way (Brittain et al., 2010, p.280, Brorsson et al., 2013, p.296). Brorsson et al. (2011) caution that "...difficulties in using signs occurred as informants had difficulties locating signs in the public space," (p.592) which means that the placement of signs have to be at eye level, and in locations where pedestrians are most likely to look. Mitchell et al. (2003) also caution against using too many signs, as this might be confusing to persons with dementia, and this in consistent with earlier findings from the wayfinding experiment run by Passini et al. (1998), which found that people with dementia are often overwhelmed by a long list of signs or directory. Another fact to consider is that putting maps on signs (such as a 'You are Here' sign) "proved impossible to use as a navigation device [for someone with dementia]," (Blackman et al., 2007, p.821).

Perhaps most interesting were the findings from Blackman et al. (2007) and the virtual reality study, in which they found that people with dementia understand explicitly worded or numbered 
signs much more than icons or photographs. These authors note that this is consistent with earlier findings and that "The retention of semantic memory among many people with Alzheimer's disease, despite the impairment of episodic memory, also points to the likely value of clear word signs, for many are understandable even though their abilities are significantly impaired," (p.821). For these authors, installing simple text signs is the most effective way to improve wayfinding in the built environment for those with dementia. The "...labeling of features in the outdoor environment as an explicit adaptation for those with dementia would benefit others and raise awareness of the disease... [And] even the small improvements from such changes would represent a large global gain," (p.823). The use of icons on wayfinding signs is an attempt to provide increased accessibility for those who do not speak the local language, and could still be incorporated into textual signs, which would end up benefiting the great number of persons with dementia.

\section{Planning Principles Literature}

\section{"The Image of the City", K. Lynch, 1960}

Street signs are, according to Lynch, a very recent invention, considering how people have navigating since the beginning of human existence. There are numerous examples of people using landmarks to navigate, often based on systems of meaning - an example of this is the Inuit navigating by the wind and snow to orient themselves (p.132). Perhaps most interesting is the case of the city of Florence, Italy, in which the naming of paths did not occur until 1785, and numbering not until 1808. Residents navigated the city by referring to canti, (which provided a description and locational reference for local areas). Canti represented focal points within the area, such as a famous family's house, square or pharmacy (p. 130).

Much of Lynch's book is focused on creating a legible city based on a series of elements, paths, landmarks, edges, nodes and districts, and using these elements as the most effective method of wayfinding and creating connections to space. That being said, well-placed street signs have been shown by other research to help newcomers to a city as well as those who might lose their way. 
Lynch (1960) does mention that directional signs must be visually connected to something. He cites a study in which drivers along a freeway had difficulty knowing when to exit as they were disconnected from the city below it (p.56-57). This could have an impact on deciding where to place directional signs in a subdivision, and making sure that they connect visually with another physical entity.

\section{Resilient City "Urban Design Principles'}

Clear Signs could contribute to achieving ResilientCity's first principle "Density, Diversity and Mix" as well as the second principle "Pedestrians First." The first principle encourages mixed use areas so a variety of amenities can be located close together and are "accessible to a diversity of users," which can be achieved by installing appropriate wayfinding signs. The second principle states that walking should be prioritized "as the preferred mode of travel and as a defining component of a healthy quality of life," but most importantly, defines a pedestrian as including persons with disabilities. Environments that promote healthy active living for all groups, including the more vulnerable, make for sustainable cities where people can live, work learn and play, and providing signs that can help those with dementia is a small step towards that. Signs can also contribute to Principle 4-Placemaking, by helping define the area as friendly for all users and help create a sense of identity. 


\begin{tabular}{|c|c|c|c|}
\hline \multicolumn{4}{|c|}{ Table 10: Clear Signs } \\
\hline Jurisdiction & Policy & $\begin{array}{l}\text { Applicable } \\
\text { Sections* }\end{array}$ & Summary \\
\hline \multirow[t]{2}{*}{$\begin{array}{l}\text { Province of } \\
\text { Ontario }\end{array}$} & $\begin{array}{l}\text { Provincial Policy } \\
\text { Statement }\end{array}$ & $\begin{array}{l}1.1 \\
1.5 .1 \\
4.6\end{array}$ & $\begin{array}{l}\text { Not explicitly mentioned, but PPS points to the } \\
\text { need to remove barriers for persons with } \\
\text { disabilities as well as older persons. Clear signs } \\
\text { have been demonstrated as a way to aid persons } \\
\text { with dementia in navigating the world outside } \\
\text { their front door. Clear Signs are a quick way to } \\
\text { improve accessibility to outdoor environments for } \\
\text { those with dementia and is a step toward fuller } \\
\text { participation for those with dementia into society. }\end{array}$ \\
\hline & $\begin{array}{l}\text { Growth Plan for } \\
\text { the Greater } \\
\text { Golden } \\
\text { Horseshoe }\end{array}$ & $\begin{array}{l}2.2 .2 .1 \mathrm{~d}) \\
2.2 .7 \\
2.22\end{array}$ & $\begin{array}{l}\text { Not explicitly mentioned, but GP instructs that } \\
\text { greenfield development shall be compact, with } \\
\text { urban form and design that supports walking and } \\
\text { creates high quality public space. Clear signs will } \\
\text { encourage walking for those with dementia and } \\
\text { may make the pedestrian environment more } \\
\text { inviting to others. }\end{array}$ \\
\hline $\begin{array}{l}\text { Region of } \\
\text { Durham }\end{array}$ & Official Plan & $\begin{array}{l}2.2 .5 \\
2.3 .5 \\
2.2 .10 \\
8.1 .4 \\
8.1 .10 \\
8.3 .10 \\
8.2 .1 \\
8 C .1 .6 \\
8 C .2 .9\end{array}$ & $\begin{array}{l}\text { Not explicitly mentioned, but the Regional OP } \\
\text { seeks to encourage area municipalities to create } \\
\text { urban design guidelines as well as lighting and } \\
\text { signs control. Development is to take aesthetics } \\
\text { into account, promote a sense of community, } \\
\text { encourage pedestrian oriented environments, and } \\
\text { promote compact urban form that encourages } \\
\text { active transit. Clear Signs can help fulfill these } \\
\text { directions. }\end{array}$ \\
\hline \multirow[t]{4}{*}{$\begin{array}{l}\text { Town of } \\
\text { Whitby }\end{array}$} & Official Plan & $\begin{array}{l}\text { 8.1.3.7.10 } \\
10.1 \cdot 13.4\end{array}$ & $\begin{array}{l}\text { Not explicitly mentioned, but the Whitby OP seeks } \\
\text { to encourage pedestrian facilities that improve } \\
\text { accessibility for persons with disabilities. Clear } \\
\text { Signs are one way to fulfill these directions. }\end{array}$ \\
\hline & $\begin{array}{l}\text { Zoning By-law } \\
2585\end{array}$ & $\mathrm{n} / \mathrm{a}$ & \\
\hline & $\begin{array}{l}\text { Engineering } \\
\text { Standards }\end{array}$ & F2.02 & $\begin{array}{l}\text { Details that street signs shall be white lettering on } \\
\text { a reflective bright blue background with a } \\
\text { character height of } 15 \mathrm{~cm} \text { (for local roads) or } 20 \mathrm{~cm} \\
\text { (for all others). }\end{array}$ \\
\hline & $\begin{array}{l}\text { Landscape Plan } \\
\text { Guidelines }\end{array}$ & $\mathrm{n} / \mathrm{a}$ & \\
\hline
\end{tabular}

*For a full list of the exact sections detailed in this Table, please see Appendix 19 - Current Planning Frameworks List 
Town of Whitby Accessibility Standards, 2005

Section 4.4.7 is dedicated to how to design accessible signage, and include the following guidelines:

- Use both words and universal symbols, combined with directional arrows and Arabic numbers if required

- Lettering shall use a sans serif font, a width to height ratio between 3:5 and 1:1 and a stroke-width-to-height ratio of between 1:5 and 1:10 (an example is found in Figure 2)

- Shall be in contrasting tones (such as black on white, however Section 4.4.15 states that white on black is the most readable)

Figure 2-Clearview Font, used for its high visibility on Highway Systems in USA

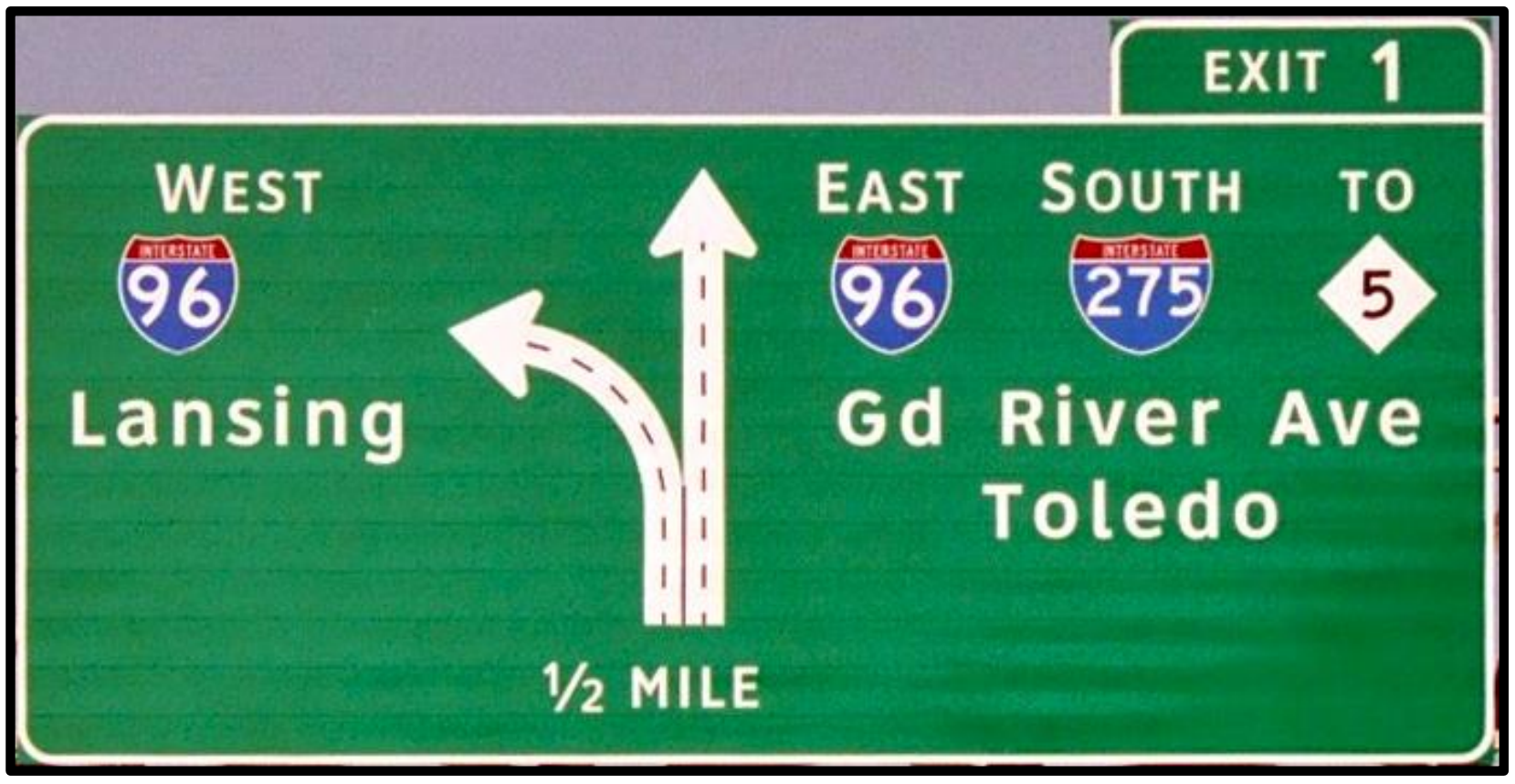

Lastly, this section includes a chart for how big signs must be created in order to be seen from certain distances. To be seen at a distance of $6 \mathrm{~m}$ from the sign (which is the farthest distance listed), the characters on the sign must be at a minimum, $20 \mathrm{~cm}$ tall. Section 4.3 says that signs fall into the category of street furniture, and this section details how to include street furniture elements on pathways, including that the furniture piece (like a sign) must not block the required sidewalk width of $1.83 \mathrm{~m}$, and should be located securely on an amenity strip measuring at least $60.1 \mathrm{~cm}$ wide (and probably made of concrete). This amenity strip could be incorporated into the buffer zone already being built in most subdivisions in Whitby, but is not required (as these standards are optional for private developers). 


\section{How can this be measured?}

When asked how much one spends in the typical subdivision on street signs - the Home Builder/Developer from Whitby stated that the cost itself was extremely negligible, covering the low cost through his road budget. The literature above suggests that those with ADRD have an easier time interpreting larger, textual signs, in black with white backgrounds. They also are more effective for wayfinding if destinations are written out, in combination with obvious symbols. The Accessibility Consultant advised that these types of signs would cost about $\$ 500$ each, which was confirmed by PC1 and PC2.

\section{How can this be economically quantified?}

This cost can be measured as an extra line item in the pro forma to see what the effect is on the ROE. In order to determine the amount of signs required, the number of intersections ( 5 as seen of Illustration 1 - Base Case Scenario) was multiplied by 4 streets to get 20 . In addition to street signs, the public features that would be located in this ideal development would be: Park, Community Post Box, and Bus Stop. Therefore, there should be signs for each of these three destinations at each intersection in the development, as well as at each of the locations. This totals 29 signs. (See Appendix 5A and 5B for the full assumptions and pro forma).

\section{Table 11: ROE Comparison (Clear Signs)}

\begin{tabular}{|l|l|}
\hline Base Case & ROE \\
\hline Base Case + Clear Signs & $46.45 \%$ \\
\hline
\end{tabular}

\section{CONCLUSION}

In conclusion, it is evident that more accessible directional signs benefit a majority of people in society, including those with dementia. The change in ROE was negligible at $0.07 \%$. This means that the Town could update their Sign By-law to require these types of treatments (especially in raising the requirement for local signs from $15 \mathrm{~cm}$ to $20 \mathrm{~cm}$, and changing the blue reflective background to a darker colour). 


\section{5 - FREQUENT SEATING}

\section{Description}

According to Burton \& Mitchell (2006), ideally seating should be located every $100-125 \mathrm{~m}$, in order to provide an appropriate amount of rest stops during journeys (p.98). In fact, the study revealed that most participants could not walk for more than 10 minutes without resting (p.108). The ideal bench has a high back, with solid armrests and non-protruding legs and is made out of wood or other material that does not conduct heat or cold (p.112). The authors also recommend that since $90 \%$ of people over the age of 75 are under $164 \mathrm{~cm}$ tall, that seating should be no higher than 440mm high (p.113). The authors also recommend providing seating of different heights to be more inclusive (p.112).

\section{Literature Review}

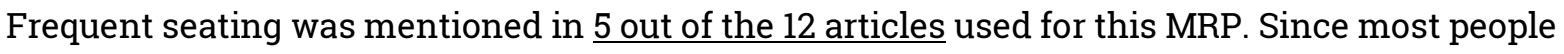
do not develop dementia until their more senior years, it is useful to note that the average 70 year old has half the strength of a healthy 20 year old, and since men are often twice as strong as women, a 20 year old man is about 4 times stronger and possesses more stamina than a 70 year old woman (Burton \& Mitchell, 2006, p.24). For this reason, walking trips even for the healthiest senior may need to be supplemented with a break (as observed by Brorsson et al., 2011, p.594). A rest stop must also be accessible, and most subdivisions (as well as many streets within a municipality) lack such places, which could be as simple as a bench.

Without rest stops, persons with dementia or seniors in general may be less likely to take trips outside, as the lack of benches can contribute to the 'unfriendliness' of the environment (Blackman et al., 2003, p. 364; Mitchell et al., 2003, p.626). As the Blackman et al. (2007) study found, participants with dementia had no difficulty identifying a modern-style benches and note that in addition to improving signage, creating more spaces free from traffic and providing convenient seating "are likely to support [the] independence [of those with dementia] and to enhance the experience of 
being outdoors," (p.822). Lastly, in regards to the design of benches, CMHC (2014) insists that benches be robust with a fairly high back and stable arm rests, so one might push themselves out of the seat (p.30).

\section{Planning Principles Literature}

\section{"The Image of the City", K. Lynch, 1960}

While Frequent Seating is not expressly mentioned within Lynch's work, such a feature could be considered a landmark in a city. Landmarks are how people make sense of their city, neighbourhood and environment. They are "another type of point reference" and can be any simple object (p.48). People most familiar to a city will use a system of landmarks to guide them, "to enjoy uniqueness and specialization," (p.78). The three aspects that make a landmark most recognizable include:

- Having a clear form

- Contrasting with its background

- Being located in a spatial area of prominence (p.78-79).

A bench in a neighbourhood would probably be located along a street (locating in a space of prominence) as well as being an obvious piece (clear form) and contrasting with its background (the houses fronting the street, or the road behind it). Thus, it has the potential to become a landmark for the neighbourhood or community. In addition, a bench could be included along a path and make up part of the set of varying characteristics that define streets as mentioned by Lynch. His work looked at several paths within cities, which all had varying characteristics (such as width, uses located along the path, the quality of the small landmarks along it, pedestrian or car congestion, what the path led to etc.) and these characteristics affected the legibility of the path in some way. The effect of the benches would likely make the neighbourhood more comfortable and safe for older persons and people with dementia. 


\section{Resilient City "Urban Design Principles'}

Frequent seating could contribute to achieving ResilientCity's second principle "Pedestrians

First." It states that walking should be prioritized "as the preferred mode of travel and as a defining component of a healthy quality of life," but most importantly, defines a pedestrian as including persons with disabilities. Environments that promote healthy active living for all groups, including the more vulnerable, make for sustainable cities where people can live, work learn and play, and providing frequent seating that can help those with dementia (and likely other groups) is a small step towards that. This Core Recommendation could also contribute to Principle 4 - Place-making, in helping to provide a sense of identity along the neighbourhood streets as an inviting place that perhaps encourages social interaction.

\section{Current Planning Frameworks}

\begin{tabular}{|c|c|c|c|}
\hline \multicolumn{4}{|c|}{ Table 12: Frequent Seating } \\
\hline Jurisdiction & Policy & $\begin{array}{l}\text { Applicable } \\
\text { Sections* }\end{array}$ & Summary \\
\hline \multirow[t]{2}{*}{$\begin{array}{l}\text { Province of } \\
\text { Ontario }\end{array}$} & $\begin{array}{l}\text { Provincial Policy } \\
\text { Statement }\end{array}$ & $\begin{array}{l}1.1 \\
1.5 .1 \\
4.6\end{array}$ & $\begin{array}{l}\text { Not explicitly mentioned, but PPS points to the } \\
\text { need to remove barriers for persons with } \\
\text { disabilities as well as older persons. There are } \\
\text { features of typical suburban environments one } \\
\text { could argue that block the rights of someone with } \\
\text { dementia to continue to be able to access their } \\
\text { neighbourhood, including a lack of places to sit and } \\
\text { rest. Not having a place to rest while on pedestrian } \\
\text { journeys have been identified as barriers by } \\
\text { persons with dementia in the literature. Removing } \\
\text { these barriers by providing public seating along } \\
\text { sidewalks for example, is a step toward fuller } \\
\text { participation for those with dementia into society. }\end{array}$ \\
\hline & $\begin{array}{l}\text { Growth Plan for } \\
\text { the Greater } \\
\text { Golden } \\
\text { Horseshoe }\end{array}$ & $\begin{array}{l}2.2 .2 .1 \mathrm{~d}) \\
2.2 .7 \\
2.22\end{array}$ & $\begin{array}{l}\text { Not explicitly mentioned, but GP instructs that } \\
\text { greenfield development shall be compact, with } \\
\text { urban form and design that supports walking and } \\
\text { creates high quality public space. Frequent Seating } \\
\text { will encourage walking for those with dementia } \\
\text { and may make the pedestrian environment more } \\
\text { inviting to others. }\end{array}$ \\
\hline $\begin{array}{l}\text { Region of } \\
\text { Durham }\end{array}$ & Official Plan & $\begin{array}{l}2.2 .5 \\
2.3 .5 \\
2.2 .10 \\
8.1 .4 \\
8.1 .10 \\
8.3 .10 \\
8.2 .1\end{array}$ & $\begin{array}{l}\text { Not explicitly mentioned, but the Regional OP } \\
\text { seeks to encourage area municipalities to create } \\
\text { urban design guidelines as well as lighting and } \\
\text { signs control. Development is to take aesthetics } \\
\text { into account, promote a sense of community, } \\
\text { encourage pedestrian oriented environments, and } \\
\text { promote compact urban form that encourages }\end{array}$ \\
\hline
\end{tabular}




\begin{tabular}{|l|l|l|l|}
\hline & & $\begin{array}{l}8 \mathrm{C} .1 .6 \\
8 \mathrm{C} .2 .9\end{array}$ & $\begin{array}{l}\text { active transit. Frequent Seating can help fulfill } \\
\text { some of these directions. }\end{array}$ \\
\hline $\begin{array}{l}\text { Town of } \\
\text { Whitby }\end{array}$ & Official Plan & $\begin{array}{l}8.1 .3 .7 .10 \\
10.1 .13 .4\end{array}$ & $\begin{array}{l}\text { Not explicitly mentioned, but the Whitby OP seeks } \\
\text { to encourage pedestrian facilities that improve } \\
\text { accessibility for persons with disabilities. Frequent } \\
\text { seating is one way to fulfill these directions. }\end{array}$ \\
\cline { 2 - 4 } & $\begin{array}{l}\text { Zoning By-law } \\
2585\end{array}$ & $\mathrm{n} / \mathrm{a}$ & \\
\cline { 2 - 4 } & $\begin{array}{l}\text { Engineering } \\
\text { Standards }\end{array}$ & $\mathrm{n} / \mathrm{a}$ & \\
\cline { 2 - 4 } & $\begin{array}{l}\text { Landscape Plan } \\
\text { Guidelines }\end{array}$ & $\mathrm{n} / \mathrm{a}$ & \\
\hline
\end{tabular}

*For a full list of the exact sections detailed in this Table, please see Appendix 19 - Current Planning Frameworks List

Town of Whitby Accessibility Standards, 2005

Section 4.3.17 outlines what street furniture is - benches, post boxes, light standards, garbage

bins, planters, signs and vending machines. The section details how to include street furniture on pathways, including that a furniture piece (such as a bench) must not block the required sidewalk width of $1.83 \mathrm{~m}$, and should be located securely on an amenity strip measuring at least $60.1 \mathrm{~cm}$ wide (and probably made of concrete). This amenity strip could be incorporated into the buffer zone already being built in most subdivisions in Whitby, but is not required (as these standards are optional for private developers). Finally, Section 4.5.5 details that benches when located within a bus shelter shall have a back and armrests at a height of between $40-45 \mathrm{~cm}$, and this could be translated as a guideline for all outdoor benches.

\section{How can this be measured?}

This could be measured by figuring out the cost of a typical street furniture quality bench and multiplying this by the number of benches required for a neighbourhood as described by Burton \& Mitchell (2006, p. 98).

\section{How can this be economically quantified?}

Since Burton \& Mitchell recommend a bench every $100-125 \mathrm{~m}$, this can be calculated by taking the total length of linear metres of road and divide by $125 \mathrm{~m}$ to get the appropriate number of benches. There are 903 linear metres of road in the base case scenario, therefore requiring 8 
benches at a cost of $\$ 1000$ each. (See Appendix 6A and 6B for the full assumptions list and pro forma).

Table 13: ROE Comparison (Frequent Seating)

\begin{tabular}{|l|l|}
\hline Base Case & ROE \\
\hline Base Case + Frequent Seating & $46.45 \%$ \\
\hline
\end{tabular}

\section{CONCLUSION}

In conclusion, it is evident that providing benches along sidewalks benefit a majority of people in society, including those with dementia. The change in ROE was negligible at $0.04 \%$. This could be added to the Landscape Design of Site Plan and Plan of Subdivision Guidelines and/or strongly suggested by Staff through the pre-consultation stage to Draft Plan approval stage. It could also be added to the Zoning By-law, when the appropriate massing of residential areas is mentioned.

\section{6 - SMALL BLOCKS AND IRREGULAR GRID PATTERN}

\section{Description}

Burton \& Mitchell (2006) encourage a legible, connected grid street layout with small blocks or $60-100 \mathrm{~m}$ in length, with narrow streets (that help people with dementia maintain concentration). An Irregular grid "creates a more interesting overall street pattern, provides direct, connected routes which are east to understand and gives people a clearer view ahead than the 90 degree turns and blind bends created by uniform grids," (p.73). The authors also advocate for alternative junctions to four way stops, like Y-Junctions, T-junctions and forked intersections, which are more likely to provide for a focal point at the end of streets (p.73). In addition, they also state that longer streets should be gently winding, in order to "provide slowly emerging views as people walk along," (p.74). All of these recommendations were in response to feedback from participants with dementia who got lost on their accompanied journeys. These persons tended to live in neighbourhoods with culde-sacs and few connected streets, which ended up being disorientating (p.70). 


\section{Literature Review}

Small Blocks and Irregular Grid Pattern were mentioned in 2 out of the 12 articles used for this MRP. The majority of the literature that mentioned the ideal type of layout of streets for those with dementia drew on interior design literature. Blackman et al. (2003) summarize previous work done by the American Institute of Architects (1985); Bell (1992); Goldsmith (1996); Brawley (1997); Judd et al. (1998); Passini et al. (2000) in saying that short corridors with frequent cues and visual access are "more navigable than long, uniform corridors with repetitive elements, fixtures and fittings," (p.363). This type of a finding might lead someone to believe that the grid system, thought of many urban designers as the most legible, permeable and clear layout for a city, might be the best layout for those with dementia (Mitchell et al., 2003, p.623).

However, Blackman et al. (2003) notes that this kind of repetitive pattern, especially with fourway junctions and streets that look identical, could end up being disabling for someone with dementia - "Short, direct routes without dead ends and small explicit spaces without sharp corners are likely to be less disabling," (p.365). Mitchell et al. (2003) stress that the grid system should not be discounted altogether, instead "small, heterogeneous streets laid out on a deformed grid based on an adapted perimeter block pattern with direct, connected routes, few nodes and junctions, and visual access along routes would provide the legibility necessary for older people with dementia (Gehl, 1996; Judd et al, 1998; McCluskey, 1992)," (p.623). Through the examination of this literature, it seems that a modified grid system would be the best choice, however it cannot be done in isolation to help people with dementia - it has to be done in conjunction with other elements such as varying built form, intersections and providing place-making treatments.

\section{Planning Principles Literature}

\section{"The Image of the City", K. Lynch, 1960}

Paths are one of Lynch's five symbols that make up a city and make up the routes by which people move around the city. Paths were identified in interviews as "the predominant city elements," (p.49). Lynch mentions that small grid systems are often the most legible for people, as 
they happen to be the simplest and most predictable pattern (p.105-106). Finally, Lynch discusses how "...more abrupt directional shifts may enhance visual clarity by limiting the spatial corridor and by providing prominent sites for distinctive structures," (p.56). This may be evidence that shorter blocks not only have better legibility (which could help those with dementia), but also allows users to be more connected and move more easily through a city.

\section{Resilient City "Urban Design Principles'}

Principle 2 - Pedestrians First

The idea that pedestrians should be prioritized over any other user is best supported by a small grid layout - many intersections will slow down vehicles and hopefully encourage people to walk to destinations instead. In addition, a well-connected street layout provides a more enjoyable walk for all, as well as is more legible for those with dementia. This Principle states that walking should be prioritized "as the preferred mode of travel and as a defining component of a healthy quality of life," but most importantly, defines a pedestrian as including persons with disabilities. Environments that promote healthy active living for all groups, including the more vulnerable, make for sustainable cities where people can live, work learn and play, and creating a street layout with small blocks and irregular grid can help those with dementia is a small step towards that.

Principle 5 - Complete Communities

A key piece of maintaining a $500 \mathrm{~m}$ radius for accomplishing tasks from one's house is connectivity of streets. A small grid format is the most connected street layout. 
Current Planning Frameworks

\begin{tabular}{|c|c|c|c|}
\hline Jurisdiction & Policy & $\begin{array}{l}\text { Applicable } \\
\text { Sections* }\end{array}$ & Summary \\
\hline \multirow[t]{2}{*}{$\begin{array}{l}\text { Province of } \\
\text { Ontario }\end{array}$} & $\begin{array}{l}\text { Provincial Policy } \\
\text { Statement }\end{array}$ & $\begin{array}{l}1.1 \\
1.5 .1 \\
4.6\end{array}$ & $\begin{array}{l}\text { The PPS points to the need to remove barriers for } \\
\text { persons with disabilities as well as older persons. } \\
\text { There are features of typical suburban } \\
\text { environments one could argue that block the rights } \\
\text { of someone with dementia to continue to be able to } \\
\text { access their neighbourhood. Cul-de-sacs, long and } \\
\text { dead end streets have been identified as barriers by } \\
\text { persons with dementia in their ability to access the } \\
\text { outdoor world. Removing these barriers by creating } \\
\text { a legible street pattern that takes into account their } \\
\text { specialized needs, while doing a better job of } \\
\text { connecting the neighbourhood is a step toward } \\
\text { fuller participation for those with dementia into } \\
\text { society. }\end{array}$ \\
\hline & $\begin{array}{l}\text { Growth Plan for } \\
\text { the Greater } \\
\text { Golden } \\
\text { Horseshoe }\end{array}$ & $\begin{array}{l}2.2 .2 .1 \mathrm{~d}) \\
2.2 .7 \\
2.22\end{array}$ & $\begin{array}{l}\text { GP instructs that greenfield development shall be } \\
\text { compact, with urban form and design that supports } \\
\text { walking and creates high quality public space. } \\
\text { According to the report published in } 2014 \text { by the } \\
\text { Chief Medical Officers for Health from around the } \\
\text { GTA ('Improving Health by Design'), the current } \\
\text { model of the car dependant suburb is making our } \\
\text { population physically and mentally sick. Creating } \\
\text { mixed use neighbourhoods with a connected and } \\
\text { legible street pattern encourages people to walk to } \\
\text { do errands, and can enable those with dementia to } \\
\text { interact with their community for longer. }\end{array}$ \\
\hline $\begin{array}{l}\text { Region of } \\
\text { Durham }\end{array}$ & Official Plan & $\begin{array}{l}2.2 .10 \\
8.1 .4 \\
8.1 .10 \\
8.3 .10 \\
8.2 .1 \\
\text { 8C.1.6 } \\
\text { 8C.2.9 }\end{array}$ & $\begin{array}{l}\text { Not explicitly mentioned, but the Regional OP } \\
\text { seeks to encourage area municipalities to create } \\
\text { urban design guidelines. Development is to take } \\
\text { aesthetics into account, promote a sense of } \\
\text { community, encourage pedestrian oriented } \\
\text { environments, and promote compact urban form } \\
\text { that encourages active transit. Small Blocks and } \\
\text { Irregular Grid Pattern can build a more connected } \\
\text { neighbourhood and therefore help fulfill some of } \\
\text { these directions. }\end{array}$ \\
\hline \multirow[t]{3}{*}{$\begin{array}{l}\text { Town of } \\
\text { Whitby }\end{array}$} & Official Plan & $\begin{array}{l}8 \cdot 1 \cdot 3 \cdot 1.7 \\
8 \cdot 1 \cdot 3 \cdot 7.10 \\
10.1 \cdot 13.4\end{array}$ & $\begin{array}{l}\text { The Whitby OP seeks to encourage pedestrian } \\
\text { facilities that improve accessibility for persons } \\
\text { with disabilities as well as encouraging a grid- } \\
\text { oriented street network. Small Blocks and Irregular } \\
\text { Grid is one way to fulfill these directions. }\end{array}$ \\
\hline & $\begin{array}{l}\text { Zoning By-law } \\
2585\end{array}$ & $\mathrm{n} / \mathrm{a}$ & \\
\hline & $\begin{array}{l}\text { Engineering } \\
\text { Standards }\end{array}$ & $\mathrm{n} / \mathrm{a}$ & \\
\hline
\end{tabular}




\begin{tabular}{|l|l|l|l|}
\hline & $\begin{array}{l}\text { Landscape Plan } \\
\text { Guidelines }\end{array}$ & $\mathrm{n} / \mathrm{a}$ & \\
\hline
\end{tabular}

*For a full list of the exact sections detailed in this Table, please see Appendix 19 - Current Planning Frameworks List

Town of Whitby Accessibility Standards, 2005

Small Blocks and Irregular Grid are not mentioned specifically in this document. In addition, there are no directions on how to create a layout of paths that might be more accessible to a variety of users. That being said, the document does advocate for making the distances between destination points in a facility as close and as accessible as possible (such as from an accessible parking spot to front desk inside a building). This piece could be translated to the outdoor environment as well, and the aforementioned pattern is one of the best ways to provide for connectivity and shorter travel routes.

\section{How can this be measured?}

In order to measure this recommendation, a sketch was created, trying to incorporate a small grid pattern, with long streets gently winding and being compared to the 'ideal development' as drawn in Burton \& Mitchell (2006, p.133). The result was Illustration 2: Small Blocks, Irregular Grid and Winding Streets, which was used to calculate the average percentage of roads.

\section{How can this be economically quantified?}

Illustration 2 resulted in the development becoming 29.55\% Right-of-Way (ROW), as opposed to the Base Case which was $20.1 \%$ roads. In addition, the average number of Townhouses per acre decreased from 19 lots per acre to 16.8 lots per acre. (See Appendix 7A and 7B for the full assumptions and pro forma).

Table 15: ROE Comparison (Small Blocks, Irregular Grid and Winding Streets)

\begin{tabular}{|l|l|}
\hline Base Case & ROE \\
\hline $\begin{array}{l}\text { Base Case + with Small Blocks, Irregular } \\
\text { Grid and Winding Streets }\end{array}$ & $36.45 \%$ \\
\hline
\end{tabular}

\section{CONCLUSION}

In conclusion, it is evident that this kind of street pattern could benefit a majority of people in society, including those with dementia. The change in ROE was substantial at $12.1 \%$. While this may be a large difference, it is worth noting that the ROE is still well above what a developer considers 
an appropriate rate of return (15-20\%). This street pattern is demonstrably better in helping people with dementia navigate, but also encourages all persons to walk, as the development becomes more connected. This Core Recommendation could be encouraged in the following ways:

- Minimum and maximum length of blocks could be added to the Zoning By-law and Official Plan, when the appropriate design and massing of residential areas is mentioned;

- Could be added to the Landscape Design of Site Plan and Plan of Subdivision Guidelines; or

- Strongly suggested by Staff through the pre-consultation stage to Draft Plan approval stage.

\section{7 - MARKED LEVEL CHANGES}

\section{Description}

Curbs and ramps that are tactile (usually for the visually impaired) are sometimes cited as a tripping hazard by those with dementia (Burton \& Mitchell, 2006, p.121) however, since some persons with dementia are visually impaired, it may make more sense to include such ramps. If ramps are being built, the authors note that a gradient of no higher than $5 \%$ should be used (p.100). Often, older persons trip going over curbs with edges they cannot see, and therefore Burton \& Mitchell (2006) recommend that small changes in level be replaced with flush ramps instead of steps where possible (p.103). Painting level changes are another measure used to combat this tripping hazard, and should include handrails, non-slip and non-glare surfacing (p.122). Clearly marking edges can also prevent older persons from walking into a bike lane or street (p.128).

\section{Literature Review}

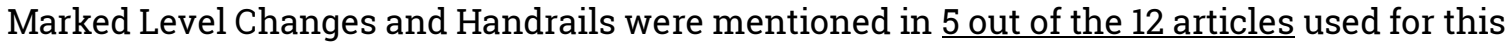
MRP. Persons with dementia suffer from impaired depth perception and a decreased ability to notice level changes between surfaces (such as from the sidewalk to road or curbs), since the materials used as often the same colour (Brorsson et al. 2014, p.7; Blackman et al. 2003, p.364). "Informants reported that they had stumbled on curbs and traffic islands and it was common that 
marks were not as distinct as they could be, for example, when the zebra crossing marks had been scuffed and worn," (Brorsson et al., 2014, p.8). In terms of ground treatments, busy patterns (such as interlocking brick, checkerboard or other designs) can be disorienting and confusing for those with dementia, and cause them to misinterpret level changes or see holes in the ground (Blackman et al., 2003, p.365).

Since level changes can be not only confusing, but a tripping hazard for those with dementia (who may also suffer from a shuffling gait), Mitchell et al. (2003) recommend that such changes are avoided altogether or to use "gentle slopes as imperceptible level changes have been found to cause stumbling and steep changes to be dangerous or onerous for frail people," (p.625). That being said, Blackman et al. (2007) found that where there was "no curb between the sidewalk and the street, dementia participants got confused. There were no road crossings marked and this also confused them," (p.817). In the base case subdivision, level changes are most likely to happen at intersections when the sidewalk transitions to the road. In order to minimize this, each of these curbs will be treated with accessible ramps. The reason why this project will not be using ramps that are flush between the sidewalk and road is that this is hazardous for those with a visual impairment (they need to be able to feel the edge of the sidewalk) and the need to identify where the road starts for those with dementia (to remind them to be careful).

When there are stairs or steep/long ramps, the CMHC (2014) report encourages the use of 1.5inch diameter handrails that are a different colour from the wall (p.24). Since the base case subdivision is assumed to be a flat site, the presence of handrails would not be required.

\section{Planning Principles Literature}

"The Image of the City", K. Lynch, 1960

Marked Level Changes and accessible ramps were not mentioned in this work.

\section{Resilient City "Urban Design Principles"}

Marked level changes could contribute to achieving ResilientCity's second principle "Pedestrians First." It states that walking should be prioritized "as the preferred mode of travel and 
as a defining component of a healthy quality of life," but most importantly, defines a pedestrian as including persons with disabilities. Environments that promote healthy active living for all groups, including the more vulnerable, make for sustainable cities where people can live, work learn and play, and providing marked level changes that can help those with dementia is a small step towards that.

\section{Current Planning Frameworks}

\begin{tabular}{|c|c|c|c|}
\hline Jurisdiction & Policy & $\begin{array}{l}\text { Applicable } \\
\text { Sections* }\end{array}$ & Summary \\
\hline \multirow[t]{2}{*}{$\begin{array}{l}\text { Province of } \\
\text { Ontario }\end{array}$} & $\begin{array}{l}\text { Provincial Policy } \\
\text { Statement }\end{array}$ & $\begin{array}{l}1.1 \\
1.5 .1 \\
4.6\end{array}$ & $\begin{array}{l}\text { Not explicitly mentioned, but PPS points to the } \\
\text { need to remove barriers for persons with } \\
\text { disabilities as well as older persons. Marked Level } \\
\text { Changes and handrails have been demonstrated as } \\
\text { a way to aid persons with dementia in navigating } \\
\text { the world outside their front door. They are a quick } \\
\text { way to improve accessibility to outdoor } \\
\text { environments for those with dementia and is a } \\
\text { step toward fuller participation for those with } \\
\text { dementia into society. }\end{array}$ \\
\hline & $\begin{array}{l}\text { Growth Plan for } \\
\text { the Greater } \\
\text { Golden } \\
\text { Horseshoe }\end{array}$ & $\begin{array}{l}2.2 .2 .1 \mathrm{~d}) \\
2.2 .7 \\
2.22\end{array}$ & $\begin{array}{l}\text { Not explicitly mentioned, but GP instructs that } \\
\text { greenfield development shall be compact, with } \\
\text { urban form and design that supports walking and } \\
\text { creates high quality public space. Marked Level } \\
\text { Changes will encourage walking for those with } \\
\text { dementia (as it makes the environment safer) and } \\
\text { may make the pedestrian environment more } \\
\text { inviting to others. }\end{array}$ \\
\hline $\begin{array}{l}\text { Region of } \\
\text { Durham }\end{array}$ & Official Plan & $\begin{array}{l}2.2 .10 \\
8.1 .4 \\
8.1 .10 \\
8.3 .10 \\
8.2 .1 \\
8 C .1 .6 \\
8 C .2 .9\end{array}$ & $\begin{array}{l}\text { Not explicitly mentioned, but the Regional OP } \\
\text { seeks to encourage area municipalities to create } \\
\text { urban design guidelines as well as lighting and } \\
\text { signs control. Development is to take aesthetics } \\
\text { into account, promote a sense of community, } \\
\text { encourage pedestrian oriented environments, and } \\
\text { promote compact urban form that encourages } \\
\text { active transit. Marked Level Changes can help } \\
\text { fulfill some of these directions. }\end{array}$ \\
\hline \multirow[t]{2}{*}{$\begin{array}{l}\text { Town of } \\
\text { Whitby }\end{array}$} & Official Plan & $\begin{array}{l}8.1 .3 .7 .10 \\
10.1 .13 .4\end{array}$ & $\begin{array}{l}\text { Not explicitly mentioned, but the Whitby OP seeks } \\
\text { to encourage pedestrian facilities that improve } \\
\text { accessibility for persons with disabilities. Marked } \\
\text { Level Changes are one way to fulfill these } \\
\text { directions. }\end{array}$ \\
\hline & $\begin{array}{l}\text { Zoning By-law } \\
2585\end{array}$ & $\mathrm{n} / \mathrm{a}$ & \\
\hline
\end{tabular}




\begin{tabular}{|l|l|l|l|}
\hline & $\begin{array}{l}\text { Engineering } \\
\text { Standards }\end{array}$ & C.6.02.1 & $\begin{array}{l}\text { Details the requirements for curbs in new } \\
\text { developments. These consist of typical flush } \\
\text { concrete curbs with a defined slope. }\end{array}$ \\
\cline { 2 - 4 } & $\begin{array}{l}\text { Landscape Plan } \\
\text { Guidelines }\end{array}$ & $\mathrm{n} / \mathrm{a}$ & \\
\hline
\end{tabular}

*For a full list of the exact sections detailed in this Table, please see Appendix 19 - Current Planning Frameworks List

Town of Whitby Accessibility Standards, 2005

Section 4.1.10 details specifics about how to build a ramp that is accessible for both those in wheelchairs/with mobility aids, as well as for those who are visually impaired. They suggest placing two ramps on either side of a curb, to allow pedestrians to go in both directions (See Figure 3 below). Curb ramps must be $1.2 \mathrm{~m}$ wide and include features like: slip-resistance, have a detectable warning surface for those with visual impairment and have a smooth transition from sidewalk to curb to road.

Figure 3: Curb Ramp Diagrams from Accessibility Standards

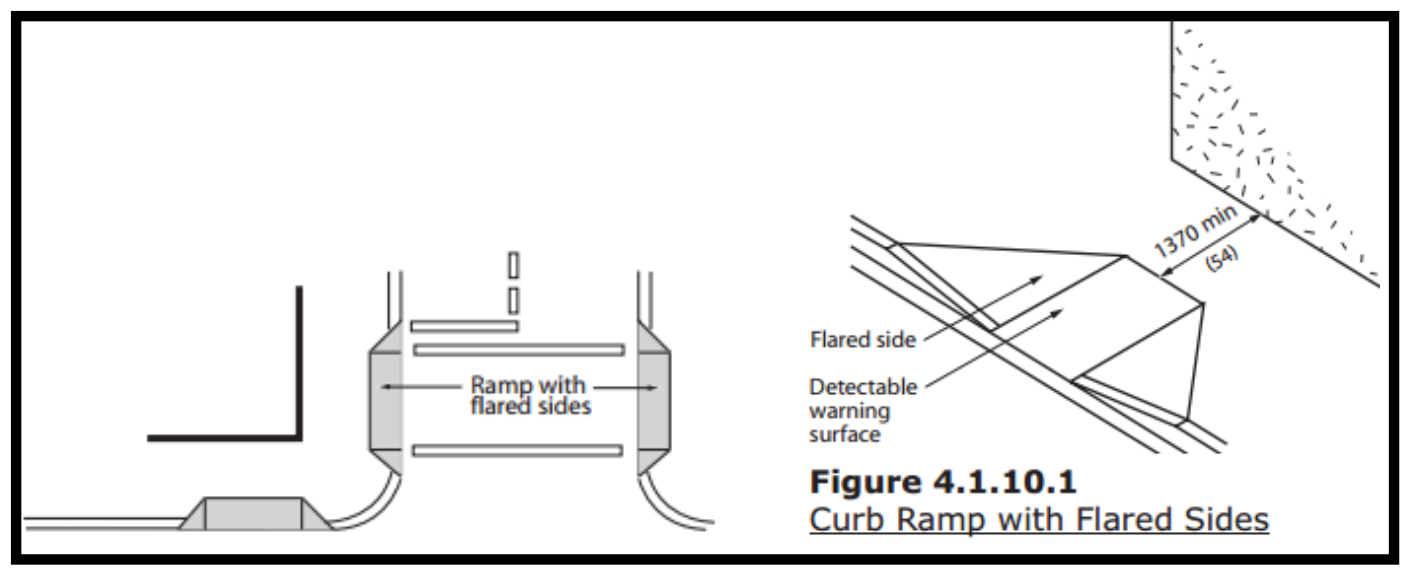

How can this be measured?

This could be measured by taking the number of intersections in the Base Case Scenario (see Illustration 1), and installing curb ramps at every intersection. For a four way intersection, that means 8 ramps at a cost of $\$ 46.95$ each.

How can this be economically quantified?

See Appendix 8A and 8B for the full assumption and pro forma. 
Table 17: ROE Comparison (Marked Level Changes)

\begin{tabular}{|l|l|}
\hline Base Case & ROE \\
\hline Base Case + with Marked Level Changes & $46.45 \%$ \\
\hline
\end{tabular}

\section{CONCLUSION}

In conclusion, it is evident that providing curb ramps benefit a number of groups in society, including those with visual impairments, those in wheelchairs, those pushing strollers or using mobility aids, in addition to those with dementia. The change in ROE was extremely negligible at $0.01 \%$. This means that the Town could incorporate this into their engineering standards to require these types of treatments on all sidewalks, could be added to the Landscape Design of Site Plan and Plan of Subdivision Guidelines or strongly suggested by Staff through the pre-consultation stage to Draft Plan approval stage.

\section{8 - GROUND LEVEL TOILETS}

\section{Description}

Incontinence occurs as people age, as bladders and bowels become weaker, meaning that older persons tend to need to use toilets more frequently than younger persons (Burton \& Mitchell, 2006, p.26). With this in mind, older people may need to use the washroom while out in the public realm, and the Burton \& Mitchell (2006) study found that the lack of public toilets already "prevents some people from going out as often as they would like," (p.108). Burton \& Mitchell (2006) suggest to remedy this by building ground level public toilets that are in view of passers-by and neighbouring buildings (to increase a sense of security) (p.114).

\section{Literature Review}

Ground level toilets were mentioned in $\underline{2}$ out of the 12 articles used for this MRP. CMHC (2014) emphasizes the importance in interior design to ensure "that toilets are easy to find," (p.19) and that their set up "should encourage and cue independent use through visual access and legibility," (p.37). 
One of the participants in the Brittain et al. (2010) study detailed that when walking outside in an unfamiliar environment and having the urge to use the toilet and not knowing where one is located is an awful situation (p.282). For older persons who may end up having to use the toilet more often than their younger counterparts, the strategic location of public facilities are crucial. Public washrooms, when well maintained and accessible, can be beneficial for everyone.

\section{Planning Principles Literature}

\section{"The Image of the City", K. Lynch, 1960}

While Ground Level Toilets are not expressly mentioned within Lynch's work, such a feature could be considered a landmark in a city. Landmarks are how people make sense of their city, neighbourhood and environment. They are "another type of point reference" and can be any simple object (p.48). People most familiar to a city will use a system of landmarks to guide them, "to enjoy uniqueness and specialization," (p.78). The three aspects that make a landmark most recognizable include:

- Having a clear form

- Contrasting with its background

- Being located in a spatial area of prominence (p.78-79).

A ground level toilet in a neighbourhood would probably be located within the park (locating in a space of prominence) as well as being an obvious building (clear form) and contrasting with its background (the park). Thus, it has the potential to become a landmark for the neighbourhood or community.

\section{Resilient City "Urban Design Principles"}

Providing ground level toilets could contribute to achieving ResilientCity's second principle "Pedestrians First." It states that walking should be prioritized "as the preferred mode of travel and as a defining component of a healthy quality of life," but most importantly, defines a pedestrian as including persons with disabilities. Environments that promote healthy active living for all groups, including the more vulnerable, make for sustainable cities where people can live, work learn and 
play, and providing ground level toilets can enable those with dementia to fully participate in society as pedestrians.

Current Planning Frameworks

\begin{tabular}{|c|c|c|c|}
\hline \multicolumn{4}{|c|}{ Table 18: Ground Level Toilets } \\
\hline Jurisdiction & Policy & $\begin{array}{l}\text { Applicable } \\
\text { Sections* }\end{array}$ & Summary \\
\hline \multirow[t]{2}{*}{$\begin{array}{l}\text { Province of } \\
\text { Ontario }\end{array}$} & $\begin{array}{l}\text { Provincial Policy } \\
\text { Statement }\end{array}$ & $\begin{array}{l}1.1 \\
1.5 .1 \\
4.6\end{array}$ & $\begin{array}{l}\text { Not explicitly mentioned, but PPS points to the } \\
\text { need to remove barriers for persons with } \\
\text { disabilities as well as older persons. Ground level } \\
\text { toilets have been demonstrated as a way to aid } \\
\text { persons with dementia in navigating the world } \\
\text { outside their front door. They are a quick way to } \\
\text { improve accessibility to outdoor environments for } \\
\text { those with dementia and is a step toward fuller } \\
\text { participation for those with dementia into society. }\end{array}$ \\
\hline & $\begin{array}{l}\text { Growth Plan for } \\
\text { the Greater } \\
\text { Golden } \\
\text { Horseshoe }\end{array}$ & $\begin{array}{l}2.2 .2 .1 \mathrm{~d}) \\
2.2 .7 \\
2.22\end{array}$ & $\begin{array}{l}\text { Not explicitly mentioned, but GP instructs that } \\
\text { greenfield development shall be compact, with } \\
\text { urban form and design that supports walking and } \\
\text { creates high quality public space. Ground Level } \\
\text { Toilets will encourage walking for those with } \\
\text { dementia (as it may give them more confidence } \\
\text { when walking) and may make the pedestrian } \\
\text { environment more inviting to others. }\end{array}$ \\
\hline $\begin{array}{l}\text { Region of } \\
\text { Durham }\end{array}$ & Official Plan & $\begin{array}{l}2.2 .10 \\
8.1 .4 \\
8.1 .10 \\
8.3 .10 \\
8.2 .1 \\
8 C .1 .6 \\
8 C .2 .9\end{array}$ & $\begin{array}{l}\text { Not explicitly mentioned, but the Regional OP } \\
\text { seeks to encourage area municipalities to create } \\
\text { urban design guidelines. Development is to take } \\
\text { aesthetics into account, promote a sense of } \\
\text { community, encourage pedestrian oriented } \\
\text { environments, and promote compact urban form } \\
\text { that encourages active transit. Ground Level } \\
\text { Toilets can help fulfill some of these directions. }\end{array}$ \\
\hline \multirow[t]{4}{*}{$\begin{array}{l}\text { Town of } \\
\text { Whitby }\end{array}$} & Official Plan & $\begin{array}{l}8.1 \cdot 3.7 .10 \\
10.1 \cdot 13.4\end{array}$ & $\begin{array}{l}\text { Not explicitly mentioned, but the Whitby OP seeks } \\
\text { to encourage pedestrian facilities that improve } \\
\text { acessibility for persons with disabilities. Ground } \\
\text { Level Toilets are one way to fulfill these directions. }\end{array}$ \\
\hline & $\begin{array}{l}\text { Zoning By-law } \\
2585\end{array}$ & $\mathrm{n} / \mathrm{a}$ & \\
\hline & $\begin{array}{l}\text { Engineering } \\
\text { Standards }\end{array}$ & $\mathrm{n} / \mathrm{a}$ & \\
\hline & $\begin{array}{l}\text { Landscape Plan } \\
\text { Guidelines }\end{array}$ & $\mathrm{n} / \mathrm{a}$ & \\
\hline
\end{tabular}

*For a full list of the exact sections detailed in this Table, please see Appendix 19 - Current Planning Frameworks List 
Town of Whitby Accessibility Standards, 2005

Section 4.2.1 provides specifications on accessible toilet design, of which Figure 4 gives

detailed measurements for a stall design. For a single room toilet, there must be enough space for a person in a wheelchair to do a complete 180 degree turn. With both toilet designs, Section 4.4.15 state that fixtures should be in contrasting colours in order to be more identifiable by those with visual impairments. Finally, Section 4.2.1 states that toilets should be located along paths to provide for easy access.

Figure 4: Accessible Toilet Design as per Town's Accessibility Standards

Figure 4.2.1.1

Washroom

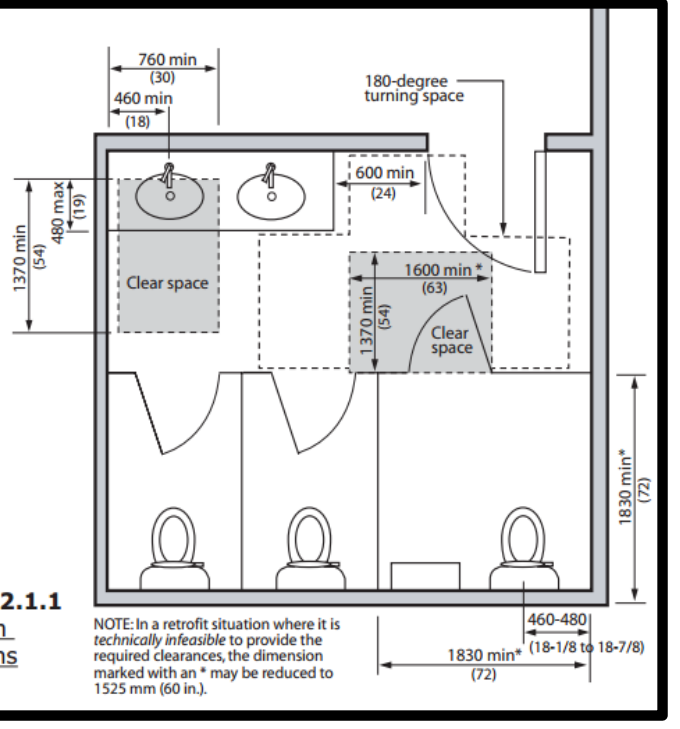

\section{How can this be measured?}

This can be measured by figuring out the cost of a public toilet. Toilets like this self-cleaning version, were purchased by the City of Toronto in 2013 for $\$ 450,000$. (See Figure 5 below, Valerie Hauch, Toronto Star, July 4th, 2013). 


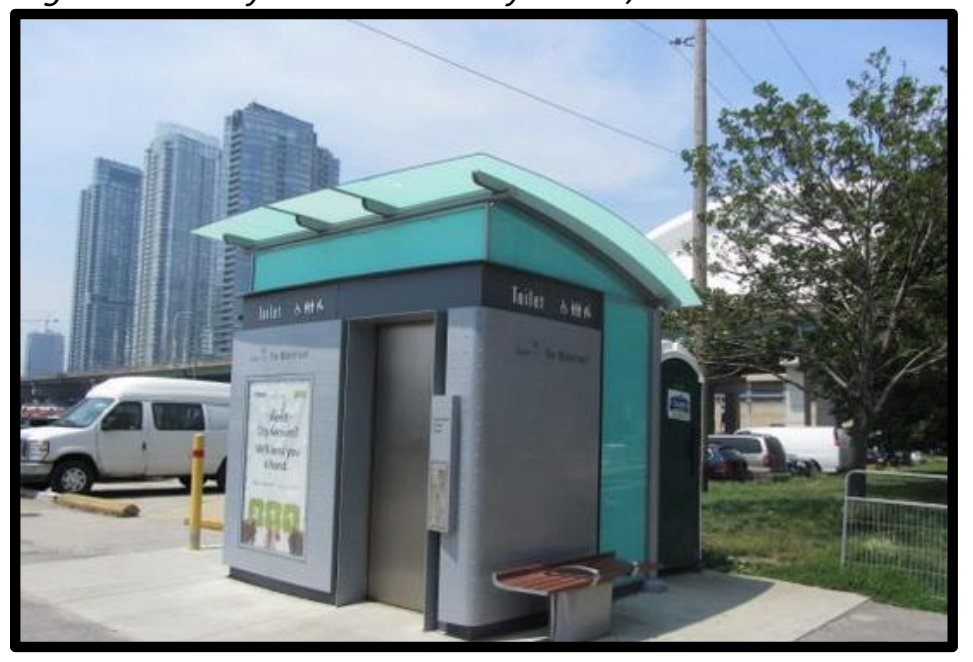

How can this be economically quantified?

See Appendix 9A and 9B for the full assumptions and pro forma.

Table 19: ROE Comparison (Ground Level Toilets)

\begin{tabular}{|ll|}
\hline Base Case Subdivision & ROE \\
\hline Base Case with Public Toilet Facilities & $46.45 \%$ \\
\hline
\end{tabular}

\section{CONCLUSION}

In conclusion, it is evident that providing extra public toilets benefit many vulnerable groups in society, including older persons, and those with dementia. The change in ROE was still fairly negligible considering the steep price of the toilet, at $1.98 \%$. This could be added to the Landscape Design of Site Plan and Plan of Subdivision Guidelines and strongly suggested by Staff through the pre-consultation stage to Draft Plan approval stage. It could also be added to the Zoning By-law, when the appropriate massing of residential areas is mentioned. 


\section{9 - ENCLOSED BUS SHELTERS WITH SEATING}

\section{Description}

According to Burton \& Mitchell (2006), bus shelters should provide some protection from the elements, with a roof and sides made of large clear windows (p.109). This provides an element of safety as well as comfort. Bus shelters should also include seating made of non-conductive materials with backs and arm rests, which could contribute to creating a series of rest stops for persons with dementia (p.109). In addition, since those with dementia tend to rely on transit (as opposed to driving a car), it is important to provide a place that is sheltered from the elements and makes one feel safe.

\section{Literature Review}

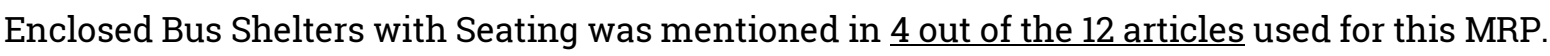
As stated in the introduction, persons with mild to moderate dementia have often lost their driver's license and rely on walking, public transport or rides from friends and family. While the issue of making the public transportation system 'dementia-friendly' is important, this review will focus on the design of bus stops, which can be influenced by a developer's design of a subdivision. Often bus stops lack seating and are unprotected from the elements. These are both seen as barriers that compromise accessibility for those with dementia, and this exposure could lead to agitation, in addition to crowding of people waiting at bus stops (Blackman et al., 2003, p. 364; Mitchell et al., 2003, p.609,626; Brorsson et al. 2014, p.9). Modern bus shelters, with seating and weather protection were approved by participants with dementia in the study completed by Blackman et al. (2007, p.819). Considering that after walking, taking public transportation is the most accessible form of transportation for those with dementia, it is important to make sure that all bus stops cater to the needs of the most vulnerable. It should be noted that other features, such as no steps to get inside the shelter and enough space to turn around in, would also benefit those with mobility issues. 
Finally, enclosed bus shelters are better for everyone, especially to protect against cold winter winds, rain or even the sun.

\section{Planning Principles Literature}

\section{"The Image of the City", K. Lynch, 1960}

While Enclosed Bus Shelters are not mentioned explicitly in Lynch's work, he does describe how places where modal changes take place (such as a railway station) become important nodes for the city. Lynch (1960) describes nodes as "strategic foci" within the city landscape, as this is where "people heighten their attention...and perceive nearby elements with more than normal clarity," (p.72, 73). The reason for this is that decisions have to be made at junctions, and humans respond instinctively by being on alert. This action was repeated so often in his interviews that Lynch concluded that "elements located at junctions may automatically be assumed to derive special prominence from their location," (p.73).

In addition, when people were asked about a point on a habitual trip when they arrived in downtown Boston, they always mentioned a junction of transportation - be it an exit off a highway, a traffic circle or railroad station (p.73). Nodes thus have the potential to be very prominent pieces within a city and help people navigate, if it is memorable as well as intensifies the character of the area around it (p.77).

Lastly, Lynch advises that landmarks (like a bus stop) may have more impact on the legibility of a city when located at a junction and it increases its likelihood of being remembered (p.81). Landmarks are how people make sense of their city, neighbourhood and environment. They are "another type of point reference" and can be any simple object (p.48). People most familiar to a city will use a system of landmarks to guide them, "to enjoy uniqueness and specialization," (p.78). The three aspects that make a landmark most recognizable include:

- Having a clear form

- Contrasting with its background

- Being located in a spatial area of prominence (p.78-79). 
A bus shelter in a neighbourhood would probably be located on an arterial or collector road (locating

in a space of prominence) as well as being an obvious building (clear form) and contrasting with its background (the houses behind it). Thus, it has the potential to become a landmark for the neighbourhood or community.

\section{ResilientCity "Urban Design Principles"}

Enclosed bus shelters could contribute to achieving ResilientCity's third principle "Transit

Supportive." By providing an enclosed bus shelter, people might be more likely to use public transit (as a comfortable place to wait can be very important). Attracting a critical mass of people to use transit is key, especially in places like Whitby where the transit system is not as developed as in a major urban centre. Environments that promote the use of transit (which will then inherently get better and better) can enable those with dementia to fully participate in society, and perhaps give them the confidence to use public transit. 
Current Planning Frameworks

\begin{tabular}{|c|c|c|c|}
\hline Jurisdiction & Policy & $\begin{array}{l}\text { Applicable } \\
\text { Sections* }\end{array}$ & Summary \\
\hline \multirow[t]{2}{*}{$\begin{array}{l}\text { Province of } \\
\text { Ontario }\end{array}$} & $\begin{array}{l}\text { Provincial Policy } \\
\text { Statement }\end{array}$ & $\begin{array}{l}1.1 \\
1.5 .1 \\
4.6\end{array}$ & $\begin{array}{l}\text { Not explicitly mentioned, but PPS points to the } \\
\text { need to remove barriers for persons with } \\
\text { disabilities as well as older persons. Enclosed bus } \\
\text { shelters and seating have been demonstrated as a } \\
\text { way to aid persons with dementia in navigating } \\
\text { the world outside their front door. In addition, they } \\
\text { are imperative as they are the most used form of } \\
\text { transportation after walking for someone with } \\
\text { dementia. They are a quick way to improve } \\
\text { accessibility to outdoor environments for those } \\
\text { with dementia and is a step toward fuller } \\
\text { participation for those with dementia into society. }\end{array}$ \\
\hline & $\begin{array}{l}\text { Growth Plan for } \\
\text { the Greater } \\
\text { Golden } \\
\text { Horseshoe }\end{array}$ & $\begin{array}{l}2.2 .2 .1 \mathrm{~d}) \\
2.2 .7 \\
2.22\end{array}$ & $\begin{array}{l}\text { Not explicitly mentioned, but GP instructs that } \\
\text { greenfield development shall be compact, with } \\
\text { urban form and design that supports walking and } \\
\text { creates high quality public space. Enclosed Bus } \\
\text { Shelters may encourage those with dementia to } \\
\text { take public transit, and may make public transit } \\
\text { more inviting to others. }\end{array}$ \\
\hline $\begin{array}{l}\text { Region of } \\
\text { Durham }\end{array}$ & Official Plan & $\begin{array}{l}2.2 .10 \\
8.3 .10 \\
8.2 .1 \\
8 C .1 .6 \\
8 C .2 .9\end{array}$ & $\begin{array}{l}\text { Not explicitly mentioned, but the Regional OP } \\
\text { seeks to encourage area municipalities to create } \\
\text { urban design guidelines. Development is to take } \\
\text { aesthetics into account, promote a sense of } \\
\text { community, encourage pedestrian oriented } \\
\text { environments, and promote compact urban form } \\
\text { that encourages active and public transit. Enclosed } \\
\text { bus shelters can help fulfill some of these } \\
\text { directions. }\end{array}$ \\
\hline \multirow[t]{4}{*}{$\begin{array}{l}\text { Town of } \\
\text { Whitby }\end{array}$} & Official Plan & $\begin{array}{l}8.1 \cdot 3 \cdot 1.7 \\
8.1 \cdot 3 \cdot 8.5 \\
8.1 \cdot 3 \cdot 8.6 \\
8.1 \cdot 3 \cdot 8.7 \\
8.1 .3 .7 .10 \\
10.1 \cdot 13.4\end{array}$ & $\begin{array}{l}\text { Not explicitly mentioned, but the Whitby OP seeks } \\
\text { to encourage pedestrian facilities that improve } \\
\text { accessibility for persons with disabilities. } \\
\text { Enclosed Bus Shelters are one way to fulfill these } \\
\text { directions. IN addition, the Whitby OP discusses } \\
\text { placing bus stops within } 400 \mathrm{~m} \text { of homes to } \\
\text { encourage people to take transit, among other } \\
\text { things like encouraging a grid network to support } \\
\text { transit. Enclosed bus shelters make waiting for the } \\
\text { bus a much more pleasant experience and may } \\
\text { encourage all residents to take it more often. }\end{array}$ \\
\hline & $\begin{array}{l}\text { Zoning By-law } \\
2585\end{array}$ & $\mathrm{n} / \mathrm{a}$ & \\
\hline & $\begin{array}{l}\text { Engineering } \\
\text { Standards }\end{array}$ & $\mathrm{n} / \mathrm{a}$ & \\
\hline & $\begin{array}{l}\text { Landscape Plan } \\
\text { Guidelines }\end{array}$ & $\mathrm{n} / \mathrm{a}$ & \\
\hline
\end{tabular}

*For a full list of the exact sections detailed in this Table, please see Appendix 19 - Current Planning Frameworks List 
Town of Whitby Accessibility Standards, 2005

Section 4.5.5 provides standards for the building of enclosed bus shelters, including the following characteristics:

- Provide clear windows that allow occupants to see oncoming traffic;

- Have a least one bench with a back and armrests at a height of between $40-45 \mathrm{~cm}$;

- Have enough space within the structure to accommodate a 180 degree turn by a wheelchair;

- Be on a firm pad that in level with the existing sidewalk; and

- Have at least $1.22 \mathrm{~m}$ of space on two sides of the structure (an extension of the pad)

\section{How can this be measured?}

It can be assumed that the price quoted for the pro forma includes the cost of a bus shelter as described above, since the quote came to PC1 from a contact at Durham Transit. The cost of one bus shelter is $\$ 8000$. See Appendix 10A and 10B for the full assumptions and pro forma.

\section{How can this be economically quantified?}

Table 21: ROE Comparison (Enclosed Bus Shelters)

\begin{tabular}{|l|l|}
\hline Base Case Subdivision & ROE \\
\hline Base Case with Enclosed Bus Shelters & $46.45 \%$ \\
\hline
\end{tabular}

\section{CONCLUSION}

In conclusion, it is evident that providing enclosed bus stops benefit everyone in society, including those with dementia, and especially people who rely on public transit. In addition, the change in ROE was negligible $0.04 \%$. This could be added to the Landscape Design of Site Plan and Plan of Subdivision Guidelines and strongly suggested by Staff through the pre-consultation stage to Draft Plan approval stage. It could also be added to the Zoning By-law, when the appropriate massing of residential areas is mentioned. 


\subsection{0 - VARIED URBAN FORM AND ARCHITECTURE}

\section{Description}

Burton \& Mitchell (2006) quotes Llewelyn-Davies (2000) in that people (at any age) do not necessarily take the most convenient route to places - "they are also influenced by how interesting or dull each route is," (p.79). This was found to be the case in the Burton \& Mitchell (2006) study, in that participants chose uncomplicated routes but with "more variety of land use, building form and architectural features even though they were not the shortest route," (p.79). Many participants stated that rows of identical houses were very confusing and they were more likely experience disorientation (p.79). One way to combat this and provide 'distinctiveness' to a neighbourhood is by varying uses and architectural styles as well as the materials used to build a house (such as different porches, colours of doors, gardens, roof lines etc.) (p.87). It is about finding the right balance of maintaining the character of a neighbourhood, as well as making sure each street is "distinctive from their neighbours," (p.87).

\section{Literature Review}

Varied Urban Form and Architecture was mentioned in 3 out of the 12 articles used for this MRP. The literature that mentioned this drew on the interior design literature of long term care homes. Long, uniform corridors have a disorientating effect on persons with dementia, which suggests that "in outdoor environments long uniform and repetitious streets and building frontages could have a similar effect," (Blackman et al., 2003, p.365). Mitchell et al. (2003) report that these types of corridors, combined with "repetitive architectural elements, fixtures and finishes lack the clarity required for successful orientation and wayfinding," (p.623). This type of repetition can also be found in a typical subdivision, where houses are built with the extremely similar features and colour schemes. 


\section{Planning Principles Literature}

\section{"The Image of the City", K. Lynch, 1960}

Lynch (1960) was a strong advocate for the need to make streets identifiable by their individual design, materials, colours, lighting, boundaries, vegetation, and skyline. Varied urban form adds to a landscape. Lynch notes that "where major paths lacked identity, or were easily confused with one for the other, the entire city image was in difficulty," (p.52). This is one of the primary reasons for encouraging developers to build a variety of house forms within a subdivision.

Lynch's work looked at several paths within cities, which all had varying characteristics (such as width, uses located along the path, the quality of the small landmarks along it, pedestrian or car congestion, what the path led to etc.) and these characteristics affected the legibility of the path in some way. This variance in path features (which includes houses fronting the path) helped people to understand where they were in the city, such as in a specific district or area. Residential neighbourhoods with varying built form types can improve the legibility and imageability of a space, attaching meaning to a path. Attaching meaning to place helps one to remember and cement navigational cues within our memories (as Lynch notes in his exploration of indigenous peoples) as well as giving us clues as to where that path might lead, or how to behave on it.

\section{ResilientCity "Urban Design Principles"}

Varied Urban Form and Architecture could contribute to achieving the following principles from

ResilientCity.

\section{Principle 1 - Density, Diversity and Mix}

In combination with other aspects, the Principle also encourages a variety of building types in order to build a more resilient neighbourhood, and that is what this Core Recommendation seeks to achieve.

\section{Principle 2 - Pedestrians First}

The principle defines a pedestrian as including those with disabilities. In providing varied urban form, one is potentially contributing to making a neighbourhood more legible for a person with 
dementia, and therefore encouraging them to retain their dignity by continuing to walk throughout their neighbourhood.

Principle 5 - Complete Communities

In combination with locating uses like retail and the doctor's office within a $500 \mathrm{~m}$ radius of

residential neighbourhoods, this principle speaks of the need to create streets that are enjoyable to walk on. Providing a mix of building forms and types is interesting and keeps the user engaged far more than a monolithic traditional suburb.

\begin{tabular}{|c|c|c|c|}
\hline \multicolumn{4}{|c|}{ Table 22: Varied Urban Form + Architecture } \\
\hline Jurisdiction & Policy & $\begin{array}{l}\text { Applicable } \\
\text { Sections* }\end{array}$ & Summary \\
\hline \multirow[t]{2}{*}{$\begin{array}{l}\text { Province of } \\
\text { Ontario }\end{array}$} & $\begin{array}{l}\text { Provincial Policy } \\
\text { Statement }\end{array}$ & $\begin{array}{l}1.1 \\
1.5 .1 \\
4.6\end{array}$ & $\begin{array}{l}\text { Not explicitly mentioned, but PPS points to the } \\
\text { need to remove barriers for persons with } \\
\text { disabilities as well as older persons. There are } \\
\text { features of typical suburban environments one } \\
\text { could argue that block the rights of someone with } \\
\text { dementia to continue to be able to access their } \\
\text { neighbourhood. Monolithic neighbourhoods with } \\
\text { similar architecture and built form have been } \\
\text { identified as barriers by persons with dementia, as } \\
\text { it makes it far more difficult to navigate their } \\
\text { environment. Removing these barriers by building } \\
\text { more architectural styles within a development for } \\
\text { example, is a step toward fuller participation for } \\
\text { those with dementia into society. }\end{array}$ \\
\hline & $\begin{array}{l}\text { Growth Plan for } \\
\text { the Greater } \\
\text { Golden } \\
\text { Horseshoe }\end{array}$ & $\begin{array}{l}2.2 .2 .1 \mathrm{~d}) \\
2.2 .7 \\
2.22\end{array}$ & $\begin{array}{l}\text { Not explicitly mentioned, but GP instructs that } \\
\text { greenfield development shall be compact, with } \\
\text { urban form and design that supports walking and } \\
\text { creates high quality public space. Varied Urban } \\
\text { Form and Architecture can make public space } \\
\text { more interesting and inviting to others as well. }\end{array}$ \\
\hline $\begin{array}{l}\text { Region of } \\
\text { Durham }\end{array}$ & Official Plan & $\begin{array}{l}2.2 .5 \\
2.3 .5 \\
2.2 .10 \\
4.3 .1 \\
8.1 .4 \\
8.1 .10 \\
8.3 .10 \\
8.2 .1 \\
8 C .1 .6 \\
8 C .2 .9\end{array}$ & $\begin{array}{l}\text { Not explicitly mentioned, but the Regional OP } \\
\text { seeks to encourage area municipalities to create } \\
\text { urban design guidelines. Development is to take } \\
\text { aesthetics into account, promote a sense of } \\
\text { community, encourage pedestrian oriented } \\
\text { environments, and promote compact urban form } \\
\text { that encourages active and public transit. Varied } \\
\text { Urban Form and Architecture can help fulfill some } \\
\text { of these directions. They also mention that areas } \\
\text { outside of the urban boundary shall be single } \\
\text { detached and consistent with the character of the } \\
\text { area. This could potentially be a barrier to varied } \\
\text { urban form. }\end{array}$ \\
\hline
\end{tabular}




\begin{tabular}{|c|c|c|c|}
\hline \multirow[t]{4}{*}{$\begin{array}{l}\text { Town of } \\
\text { Whitby }\end{array}$} & Official Plan & $\begin{array}{l}4.2 .3 .13 \\
4.2 .3 .14 \\
8.1 .3 .7 .10 \\
10.1 .13 .4 \\
11.8 .7 .2\end{array}$ & $\begin{array}{l}\text { Not explicitly mentioned, but the Whitby OP seeks } \\
\text { to encourage pedestrian facilities that improve } \\
\text { accessibility for persons with disabilities. Varied } \\
\text { Urban Form and Architecture are one way to fulfill } \\
\text { these directions. It also states that a range of } \\
\text { tenure types and built forms shall be encouraged in } \\
\text { the Major Central Area. This could be more } \\
\text { effective if it was applied to all areas within the } \\
\text { urban boundary. }\end{array}$ \\
\hline & $\begin{array}{l}\text { Zoning By-law } \\
2585\end{array}$ & $\mathrm{n} / \mathrm{a}$ & \\
\hline & $\begin{array}{l}\text { Engineering } \\
\text { Standards }\end{array}$ & $\mathrm{n} / \mathrm{a}$ & \\
\hline & $\begin{array}{l}\text { Landscape Plan } \\
\text { Guidelines }\end{array}$ & $\mathrm{n} / \mathrm{a}$ & \\
\hline
\end{tabular}

*For a full list of the exact sections detailed in this Table, please see Appendix 19 - Current Planning Frameworks List

Town of Whitby Accessibility Standards, 2005

Varied urban form and architecture are not mentioned in this document.

\section{How can this be measured?}

In order to understand what the cost might be to a developer of incorporating more than one style of home (and by style, the author means a completely different design, as opposed to most subdivisions, which have different models of the same design style), a personal communication with an established Whitby Home Builder/Developer was conducted. The inquiry sought to understand what the cost of building homes in a subdivision that varied in architectural style from street to street, in order to enhance the legibility of the subdivision. From personal experience, navigating a subdivision (with even with a dozen models of the same design) can be extremely confusing, even after many years.

\section{How can this be economically quantified?}

It was revealed through the interview that on average, a completely new design of a home style, working with an architect would cost about $\$ 2$ per square foot of house. From that new design, it costs about $\$ 0.75$ per square foot to create different models (which is what typical subdivisions do) (Personal Communication with HB/D, March 12, 2015). In order to evaluate this, a combination of 2 designs with 1 extra model each for each street was calculated. Then the number of streets, minus one (this is to account for the architectural designs already assumed in the HB/D's 
soft costs) would be multiplied against this. (See Appendix 11A and 11B for the full assumptions and pro forma).

Table 22: Calculations for New House Designs

\begin{tabular}{|l|c|c|c|} 
House Type & $\begin{array}{c}\text { Typical Square } \\
\text { Footage }\end{array}$ & $\begin{array}{c}\text { Cost of a new design style } \\
(\$ 2 / \text { sqft })\end{array}$ & $\begin{array}{c}\text { Cost of a new model (derived from a } \\
\text { new style) }(\$ 0.75 / \text { sqft) }\end{array}$ \\
\hline Townhouse & 1500 & $\$ 3000$ & $\$ 1125$ \\
\hline
\end{tabular}

Total Number of Streets: 3

Two new designs +1 models each $=\$ 8,250$

TOTAL COST: $\$ 16,500$ (2 streets $\mathrm{x} \$ 8,250)$

Table 23: ROE Comparison (Varied Urban Form + Architecture)

\begin{tabular}{|l|l|}
\hline Base Case & ROE \\
\hline Base Case + Cost of New Designs & $46.45 \%$ \\
\hline
\end{tabular}

In addition, when asked if building homes in different styles (such as having modern townhouses on one street and Georgian townhouses on the next) would add to construction or other hard and soft costs, the Home Builder/Developer said "No. The only extra cost would be in paying for the new designs." The developer mentioned that there might be differences between styles in terms of cost of materials and square footage, but this would be reflected in the price of the home.

\section{CONCLUSION}

In conclusion, it is evident that designing neighbourhoods that includes variety in built form with benefit everyone in society in regards to orientation, including those with dementia. In addition, the change in ROE was negligible $0.07 \%$. This means that the Town could do a number of things, like changing Sec. 11.8.7.2 of the Whitby Official Plan to encourage a variety of built form types for all areas within the urban boundary. This could be added to the Landscape Design of Site Plan and Plan of Subdivision Guidelines and/or strongly suggested by Staff through the preconsultation stage to Draft Plan approval stage. It could also be added to the Official Plan or Zoning By-law, when the appropriate massing of residential areas is mentioned. 


\subsection{1 - BUFFER ZONES BETWEEN ROAD AND SIDEWALKS}

\section{Description}

Burton \& Mitchell (2006) note that buffer zones (of trees, shrubs, fencing etc.) "can help shield pedestrians from traffic" as well as place a physical barrier between pedestrians and cyclists/motorists," (p.109). It also has the potential to cut down on the noise from traffic and "reduce street and background noises," (p.109).

\section{Literature Review}

Buffer Zones between roads and sidewalks were mentioned in 2 out of the 12 articles used for this MRP. Brorsson et al. (2014) note that separating cyclists from pedestrians could increase perceived accessibility for persons with dementia (p.12). The same authors also note that persons with dementia do not know how to act in a street where cars and pedestrians are mixed (p.12). That being said, a study cited by Mitchell et al. (2003) notes that pedestrianized streets (without cars) have "enhanced the ability of older people and people with disabilities to enter and use the town centre because of the improved quality and safety of an environment protected from the noise, danger, and fumes of motorized vehicles," (p.626). This study did not take into account of the specific needs of those with dementia, but is an interesting finding.

\section{Planning Principles Literature}

\section{"The Image of the City", K. Lynch, 1960}

While 'buffer zones' are not mentioned expressly by Lynch (1960), he does describe features of paths that have an impact on their legibility and imageability. Things like spatial quality (width of sidewalks or roads), special facade characteristics, and even plantings (but only if there is a great deal of them) have an impact (p.50,51). This could mean that 'buffer zones' are one way to make a path more legible to users. 


\section{ResilientCity "Urban Design Principles"}

Buffer Zones could contribute to achieving the following principles from ResilientCity:

Principle 2 - Pedestrians First

The principle defines a pedestrian as including those with disabilities, and prioritizing their needs over the automobile. In providing Buffer Zones between the sidewalk and road, the sidewalk is perceived as safer for a person with dementia, provides a space to locate much needed street

furniture as well potentially making the walk itself more interesting and therefore legible for a person with dementia. All of these benefits could encourage someone with dementia to retain their dignity by enabling them to continue to walk throughout their neighbourhood.

Principle 5 - Complete Communities

In combination with locating uses like retail and the doctor's office within a $500 \mathrm{~m}$ radius of residential neighbourhoods, this principle speaks of the need to create streets that are enjoyable to walk on. Providing Buffer Zones (with trees and street furniture) may make the walk interesting and keep the user engaged far more than a monolithic traditional suburb. 
Current Planning Frameworks

\begin{tabular}{|c|c|c|c|}
\hline Jurisdiction & Policy & $\begin{array}{l}\text { Applicable } \\
\text { Sections* }\end{array}$ & Summary \\
\hline \multirow[t]{2}{*}{$\begin{array}{l}\text { Province of } \\
\text { Ontario }\end{array}$} & $\begin{array}{l}\text { Provincial Policy } \\
\text { Statement }\end{array}$ & $\begin{array}{l}1.1 \\
1.5 .1 \\
4.6\end{array}$ & $\begin{array}{l}\text { Not explicitly mentioned, but PPS points to the } \\
\text { need to remove barriers for persons with } \\
\text { disabilities as well as older persons. Providing } \\
\text { buffer zones is a step toward fuller participation for } \\
\text { those with dementia into society and may help to } \\
\text { encourage active transportation. }\end{array}$ \\
\hline & $\begin{array}{l}\text { Growth Plan for } \\
\text { the Greater } \\
\text { Golden } \\
\text { Horseshoe }\end{array}$ & $\begin{array}{l}2.2 .2 .1 \mathrm{~d}) \\
2.2 .7 \\
2.22\end{array}$ & $\begin{array}{l}\text { Not explicitly mentioned, but GP instructs that } \\
\text { greenfield development shall be compact, with } \\
\text { urban form and design that supports walking and } \\
\text { creates high quality public space. Buffer Zones } \\
\text { may encourage those with dementia to walk more } \\
\text { often as they may feel more secure. Landscaped } \\
\text { buffer zones also are more aesthetically pleasing. }\end{array}$ \\
\hline $\begin{array}{l}\text { Region of } \\
\text { Durham }\end{array}$ & Official Plan & $\begin{array}{l}2.2 .5 \\
2.3 .5 \\
2.2 .10 \\
2.3 .47 \\
8.1 .4 \\
8.1 .10 \\
8.2 .1\end{array}$ & $\begin{array}{l}\text { Not explicitly mentioned, but the Regional OP } \\
\text { seeks to encourage area municipalities to create } \\
\text { urban design guidelines. Development is to take } \\
\text { aesthetics into account, promote a sense of } \\
\text { community, encourage pedestrian oriented } \\
\text { environments, promote tree planting and promote } \\
\text { compact urban form that encourages active and } \\
\text { public transit. Buffer Zones can help fulfill some of } \\
\text { these directions. }\end{array}$ \\
\hline \multirow[t]{4}{*}{$\begin{array}{l}\text { Town of } \\
\text { Whitby }\end{array}$} & Official Plan & $\begin{array}{l}\text { 8.1.3.7.10 } \\
10.1 .13 .4\end{array}$ & $\begin{array}{l}\text { Not explicitly mentioned, but the Whitby OP seeks } \\
\text { to encourage pedestrian facilities that improve } \\
\text { accessibility for persons with disabilities. } \\
\text { Providing Buffer Zones is one way to achieve this } \\
\text { direction. }\end{array}$ \\
\hline & $\begin{array}{l}\text { Zoning By-law } \\
2585\end{array}$ & $\mathrm{n} / \mathrm{a}$ & \\
\hline & $\begin{array}{l}\text { Engineering } \\
\text { Standards }\end{array}$ & G10.0 & $\begin{array}{l}\text { In new subdivisions, developers are required to } \\
\text { plant trees along all road allowances in } \\
\text { accordance with requirements of the subdivision } \\
\text { agreement and the Town of Whitby's Standard } \\
\text { Illustrations. The developer is also required to } \\
\text { protect and maintain as many of the existing trees } \\
\text { on the development lands as possible. }\end{array}$ \\
\hline & $\begin{array}{l}\text { Landscape Plan } \\
\text { Guidelines }\end{array}$ & $\begin{array}{l}5.2 \\
5.3\end{array}$ & $\begin{array}{l}\text { Details requirements for planting street trees in the } \\
\text { boulevard or buffer zone. It also encourages this } \\
\text { within a subdivision to separate the sidewalk from } \\
\text { road. }\end{array}$ \\
\hline
\end{tabular}

*For a full list of the exact sections detailed in this Table, please see Appendix 19 - Current Planning Frameworks List 
Town of Whitby Accessibility Standards, 2005

Section 4.1.4 details the need to provide early detection or edges to paths, in order to help those with visual impairment remain on the sidewalk. Providing a grass buffer zone is one way to both physically separate the user from traffic, but also a way to warn them they are leaving the sidewalk.

\section{How can this be measured?}

The installation of 'buffer zones' between the sidewalk and the road are already incorporated into a typical subdivision in Whitby (Personal Communication with HB/D, March 12, 2015). The typical zone is 8-10ft wide and consists of a grass verge with trees, altogether costing \$89 per linear metre. Since it is already incorporated, the net effect on the ROE is $0 \%$. That being said, in order to increase legibility of streets and avoid slippery sidewalks (from large leaves falling), Town Staff might encourage different kinds of trees within subdivisions to increase distinctiveness and safety.

\section{How can this be economically quantified?}

The established Home Builder/Developer interviewed already incorporates buffer zones into his subdivisions, but quotes the cost of an 8 to $10 \mathrm{ft}$. wide grass buffer zone with trees to be $\$ 89$ per linear metre. The difference in Return on Equity for including buffer zones was $0 \%$ as you can see in Table 25. (See Appendix 12A and 12B for the full assumptions and pro forma).

\section{Table 25: ROE Comparison (Buffer Zones)}

\begin{tabular}{|l|l|}
\hline With 'Buffer Zones' & $46.45 \%$ \\
\hline Without 'Buffer Zones' & $46.45 \%$ \\
\hline
\end{tabular}

\section{CONCLUSION}

In conclusion, it is evident that incorporating 'buffer zones' is not only good for people with dementia, but for other members of a community. It provides a space to put street furniture, and other defining elements of a neighbourhood. It also already common practice within Whitby, and is required by the Engineering Standards with recommendations on planting provided by the Landscape Plan Guidelines, which is promising. 


\subsection{2 - LANDMARKS AND PLACES OF ACTIVITY}

\section{Description}

Burton \& Mitchell (2006) found that landmarks were an important part of how their participants navigated their neighbourhoods - often, they would rely on landmarks either subconsciously or when they got confused. Landmarks could be anything from a favorite tree to a corner store (p. 68). Perhaps most importantly, a landmark, no matter how large or small, aesthetic or practical, it must have been in that place for a period of time in order to be used as a wayfinding tool (p.86). This finding was deduced after they found that participants in their study "continue to remember features [in the environment] that they encounter on a regular basis," (p.37). Another important rationale for landmarks comes from Passini et al. (1998) who is quoted within the Burton \& Mitchell (2006) book. In their indoor wayfinding experiment, Passini et al. (1998) discovered that the ability to navigate complex environments (like a hospital) was diminished for someone with mild to moderate dementia, however they have developed a coping mechanism. They were able to find their way by navigating from one familiar visual cue to the next (p.86). This combined with Burton \& Mitchell's (2006) study findings that participants with dementia make a conscious effort to walk the routes in their neighbourhood and remember the visual cues to help them along in their journey (p.86).

\section{Literature Review}

Landmarks and Places of Activity were mentioned in 9 out of the 12 articles used for this MRP, one of the most frequently mentioned Core Recommendations. People with dementia have difficulty relying on mental maps, and as interior design literature has proven, they rely on visual cues "especially those with long-established, familiar, distinctive and recognizable identities," in order to find their bearings in space (Mitchell et al., 2003, p.624). Landmarks can also be used to 'help capture people's attention and concentration and enhance their living environment while helping them find their way around," (CMHC, 2014, p.19). Often, these landmarks are ones that they 
have experienced all their life and have symbolic or personal significance (Blackman et al. 2003, p. 365; Mitchell et al. 2003, p.624). In addition, participants use landmarks either subconsciously or consciously (Sheehan et al. 2006, p.278) and "are as a way of mediating between themselves [those with dementia] and the outside environment, enabling them to carry on with everyday activities." (Brittain et al., p.280).

In the Van Schaik et al. (2008) study, they found that both healthy participants and those with dementia were able to "identify similar features in the physical environment...equally likely to identify close and distant landmarks and to identify positive and negative features of the environment," (p.277). This could indicate that despite the disease, people with dementia still have the ability to use landmarks for wayfinding, as the healthy controls did, meaning that the construction of landmarks would be a useful strategy in helping these persons, as it is something they can still rely on and use (unlike a 'You are Here' map which is nearly impossible for those with dementia). The idea of a supportive environment is expanded on by Brittain et al. (2010) who relate to Gesler's (1992) concept of 'therapeutic landscapes' by arguing that for people with dementia "landscapes can become supportive in enabling someone who experiences memory loss to reorientate themselves and carry on with everyday activities that they enjoy...Physical and social landscapes in this sense are therapeutic in that they reassure and are used as an explicit way of getting home or providing a sense of security," (p.282).

While landmarks were perceived as useful tools for wayfinding, Brorsson et al. (2011) warns that "the informants experienced sensitivity to subtle changes in landmarks in the public space that influenced their perceived accessibility," (p.596). This means that even if one builds landmarks into a subdivision from the onset and they get altered in the future, they may end up confusing those with dementia (p.591). In a similar way, the Blackman et al. (2007) study found that 'adding landmarks' did not help older people to wayfind (p.818). That being said, this risk should not outweigh the benefits of integrating elements of place-making and legibility into a subdivision, 
because at present, the typical one model house design with identical streets is confusing to the able-minded.

\section{Planning Principles Literature}

\section{"The Image of the City", K. Lynch, 1960}

Landmarks are how people make sense of their city, neighbourhood and environment. In fact, neuroscientists note that human beings wayfind in two ways: through the use of landmarks, and through the use of distances and turns. Men are more likely to use the latter. However, part of their internal navigation still uses landmarks (Redel, 2015). Since the beginning of human existence, we have been attaching meaning to our landscape in order to make sense of it, and in some situations, to survive. Early examples of people using landmarks to navigate are often based on systems of meaning - such as the Inuit navigating by the wind and snow to orient themselves of Polynesian groups navigating using waves (p.132). More recently and perhaps most interesting is the case of the city of Florence, Italy, in which the naming of paths did not occur until 1785, and numbering not until 1808. Residents navigated the city by referring to canti, (which provided a description and locational reference for local areas). Canti represented focal points within the area, such as a famous family's house, square or pharmacy (p.130). Much of Lynch's book is focused on creating a legible city based on a series of elements, paths, landmarks, edges, nodes and districts, and using these elements as the most effective method of wayfinding and creating connections to space. This practice of place-making and building landmarks within a new community is merely a return to the lessons of earlier generations and creating symbolism and meaning for places, which will in turn help those with dementia.

Another important warning from Lynch (1960) was that when a city undergoes constant physical change (like in Los Angeles), there are "practical and emotional strains induced," which negatively affect the navigability of space as well as its imageability (p.86). Lynch is noticing the effect of built form change on able bodied and minded individuals - the effect on those with 
dementia can only be imagined to be much greater. In order to mitigate the effects of drastic change, Lynch says, "It would be important to know how to maintain continuity through these changes, just as ties are needed between level and level of organization, so are continuities required which persist through a major change. This might be facilitated by the retention of an old tree, a path trace, or some regional character," (p.86). In regards to infill development, the need to follow some form of Lynch's guidance would be imperative to retain legibility of the space for the public, but especially for some of the most vulnerable, like those with dementia.

\section{Resilient City.org "Urban Design Principles"}

Landmarks + Places of Activity could contribute to achieving the following principles from

ResilientCity:

\section{Principle 2 - Pedestrians First}

The principle defines a pedestrian as including those with disabilities, and prioritizing their needs over the automobile. In building landmarks in community, one is making an environment more legible for persons with dementia, as well as for able minded persons.

\section{Principle 4 - Place-making}

Inserting landmarks into a subdivision may not only add legibility for those with dementia, but also represents a step towards this principle of building places that can have meaning attached to them.

\section{Principle 5 - Complete Communities}

In combination with locating uses like retail and the doctor's office within a $500 \mathrm{~m}$ radius of residential neighbourhoods, this principle speaks of the need to create streets that facilitate walking. For those with dementia, having landmarks to help them retain their dignity by enabling them to continue to walk throughout their neighbourhood. 


\begin{tabular}{|c|c|c|c|}
\hline \multicolumn{4}{|c|}{ Table 26: Landmarks + Places of Activity } \\
\hline Jurisdiction & Policy & $\begin{array}{l}\text { Applicable } \\
\text { Sections* }\end{array}$ & Summary \\
\hline \multirow[t]{2}{*}{$\begin{array}{l}\text { Province of } \\
\text { Ontario }\end{array}$} & $\begin{array}{l}\text { Provincial Policy } \\
\text { Statement }\end{array}$ & $\begin{array}{l}1.1 \\
1.5 .1 \\
4.6\end{array}$ & $\begin{array}{l}\text { Not explicitly mentioned, but PPS points to the } \\
\text { need to remove barriers for persons with } \\
\text { disabilities as well as older persons. There are } \\
\text { features of typical suburban environments one } \\
\text { could argue that block the rights of someone with } \\
\text { dementia to continue to be able to access their } \\
\text { neighbourhood. A lack of identifiable and familiar } \\
\text { landmarks to aid in wayfinding have been } \\
\text { identified as a barrier to persons with dementia in } \\
\text { the literature. Removing these barriers by } \\
\text { installing practical and/or aesthetic landmarks is a } \\
\text { step toward fuller participation for those with } \\
\text { dementia into society. }\end{array}$ \\
\hline & $\begin{array}{l}\text { Growth Plan for } \\
\text { the Greater } \\
\text { Golden } \\
\text { Horseshoe }\end{array}$ & $\begin{array}{l}2.2 .2 .1 \mathrm{~d}) \\
2.2 .7 \\
2.22\end{array}$ & $\begin{array}{l}\text { Not explicitly mentioned, but GP instructs that } \\
\text { greenfield development shall be compact, with } \\
\text { urban form and design that supports walking and } \\
\text { creates high quality public space. Landmarks may } \\
\text { encourage those with dementia to walk more often } \\
\text { as they will probably be able to wayfind with less } \\
\text { difficulty. Landmarks also are more aesthetically } \\
\text { pleasing and contributes to building high quality } \\
\text { public space. }\end{array}$ \\
\hline $\begin{array}{l}\text { Region of } \\
\text { Durham }\end{array}$ & Official Plan & $\begin{array}{l}2.2 .5 \\
2.3 .5 \\
2.2 .10 \\
8.1 .4 \\
8.1 .10 \\
8.2 .1 \\
8 C .1 .6 \\
8 C .2 .9\end{array}$ & $\begin{array}{l}\text { Not explicitly mentioned, but the Regional OP } \\
\text { seeks to encourage area municipalities to create } \\
\text { urban design guidelines. Development is to take } \\
\text { aesthetics into account, promote a sense of } \\
\text { community, encourage pedestrian oriented } \\
\text { environments, promote tree planting and promote } \\
\text { compact urban form that encourages active transit. } \\
\text { Landmarks can help fulfill some of these } \\
\text { directions, especially in restoring a method of } \\
\text { wayfinding that human beings are more adept at } \\
\text { using. }\end{array}$ \\
\hline \multirow[t]{3}{*}{$\begin{array}{l}\text { Town of } \\
\text { Whitby }\end{array}$} & Official Plan & $\begin{array}{l}\text { 8.1.3.7.10 } \\
10.1 \cdot 13.4\end{array}$ & $\begin{array}{l}\text { Not explicitly mentioned, but the Whitby OP seeks } \\
\text { to encourage pedestrian facilities that improve } \\
\text { accessibility for persons with disabilities. } \\
\text { Providing Landmarks is one way to achieve this } \\
\text { direction. }\end{array}$ \\
\hline & $\begin{array}{l}\text { Zoning By-law } \\
2585\end{array}$ & $\mathrm{n} / \mathrm{a}$ & \\
\hline & $\begin{array}{l}\text { Engineering } \\
\text { Standards }\end{array}$ & C4.07 & $\begin{array}{l}\text { Community mail boxes shall be placed according } \\
\text { to the Canada Post Corporation requirements and } \\
\text { Standard Illustration No. } 308 \text {. Design locations for } \\
\text { super mail boxes should incorporate factors such } \\
\text { as pedestrian safety, driveway locations, traffic } \\
\text { flow and aesthetics. Community mail box }\end{array}$ \\
\hline
\end{tabular}




\begin{tabular}{|l|l|l|}
\hline & & $\begin{array}{l}\text { locations shall be indicated on the Master Utility } \\
\text { Plans. }\end{array}$ \\
\cline { 2 - 3 } & $\begin{array}{l}\text { Landscape Plan } \\
\text { Guidelines }\end{array}$ & $\begin{array}{l}\text { No discussion of place-making or landmarks or } \\
\text { establishing identity for a neighbourhood. }\end{array}$ \\
\hline
\end{tabular}

*For a full list of the exact sections detailed in this Table, please see Appendix 19 - Current Planning Frameworks List

Town of Whitby Accessibility Standards, 2005

While these Standards do not include a section about the importance of including landmarks

in areas, it does discuss how to incorporate them so that they comply with accessibility needs.

Many of the landmarks proposed by this section are included in what Section 4.3 .17 of the

Accessibility Standards outlines as street furniture- benches, post boxes, light standards, garbage

bins, planters, signs and vending machines. The section details how to include street furniture on

pathways, including that a furniture piece (such as a bench) must not block the required sidewalk

width of $1.83 \mathrm{~m}$, and should be located securely on an amenity strip measuring at least $60.1 \mathrm{~cm}$ wide

(and probably made of concrete). This amenity strip could be incorporated into the buffer zone

already being built in most subdivisions in Whitby, but is not required (as these standards are

optional for private developers). In addition, Section 4.3.14 notes that providing flowers along routes

can prove to be useful visual cues for those who are visually impaired as well as providing

landmarks. They do provide guidelines for what an accessible plant bed might look like: It should be raised at least $46 \mathrm{~cm}$ off the ground and be located along a pedestrian route. Lastly, when planters are installed on a sidewalk, they must have a $7.5 \mathrm{~cm}$ high curb around them, as these are canedetectable (for the visually impaired).

\section{How can this be measured?}

In a typical subdivision, the only landmarks are the park or open space area, entrance to the subdivision from the collector or arterial road and perhaps the community post box. In order to quantify the number of landmarks required for a hypothetical scenario subdivision of 20 acres, it was decided that the cost of the aforementioned features with place-making improvements would be quantified, along with placing street furniture and other treatments at intersections to improve their legibility. \#12 - Landmarks and Places of Activity will quantify the former, while \#14 - 
Distinctive Features at Junctions will quantify the latter. The reason for including most of the land marking features at junctions is because they are the key decision points within a subdivision, and therefore most likely to be at the end of one's line of vision (which is important for wayfinding).

\section{How can this be economically quantified?}

A community box post is another example of a potential landmark and gathering place. With the phasing out of home delivery by Canada Post, developers are being asked to install Community Post Boxes like the one in Figure 6.

Figure 6 - Typical Community Post Box Design (Canada Post)

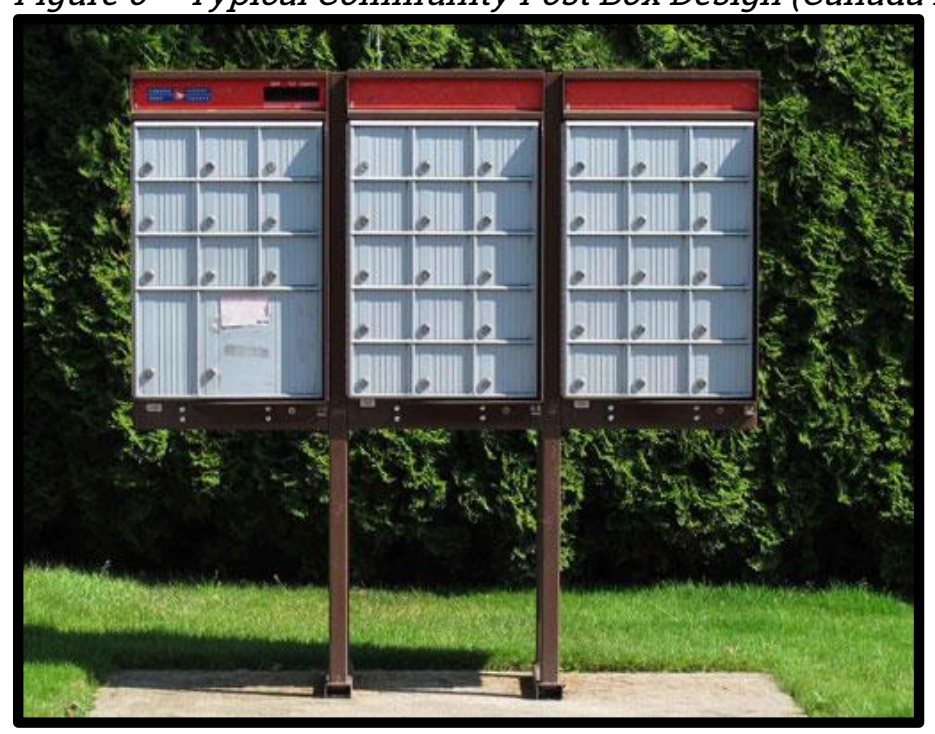

One option for encouraging interaction and place-making is to create a Community Post Box

Pavilion like the one shown in Figure 7. The open pavilion has electrical outlets and seating, measuring $12 \mathrm{ft}$ x $20 \mathrm{ft}$ and costs $\$ 22,000$ (Personal Communication with PC2, March 17, 2015). This is an opportunity to turn something that is required in a development, into a place where neighbours can go to gather or meet each other when going about their daily errands. In addition, much of the literature stressed the need for those with dementia to go for a walk that has a purpose, a final destination point. "Informants valued their ability to be able to perform activities and visit different places when it created a sense of being active and independent person who is part of society," (Brorsson et al., 2011, p.591). These kinds of trips were also valued for the exercise and an 
opportunity to interact socially (p.592). A daily trip to the Community Post Box could be one such walk and is likely to still be manageable for most persons with dementia (even as it progresses) considering it would be so close to their front door.

\section{Figure 7 - Post Box Pavilion}

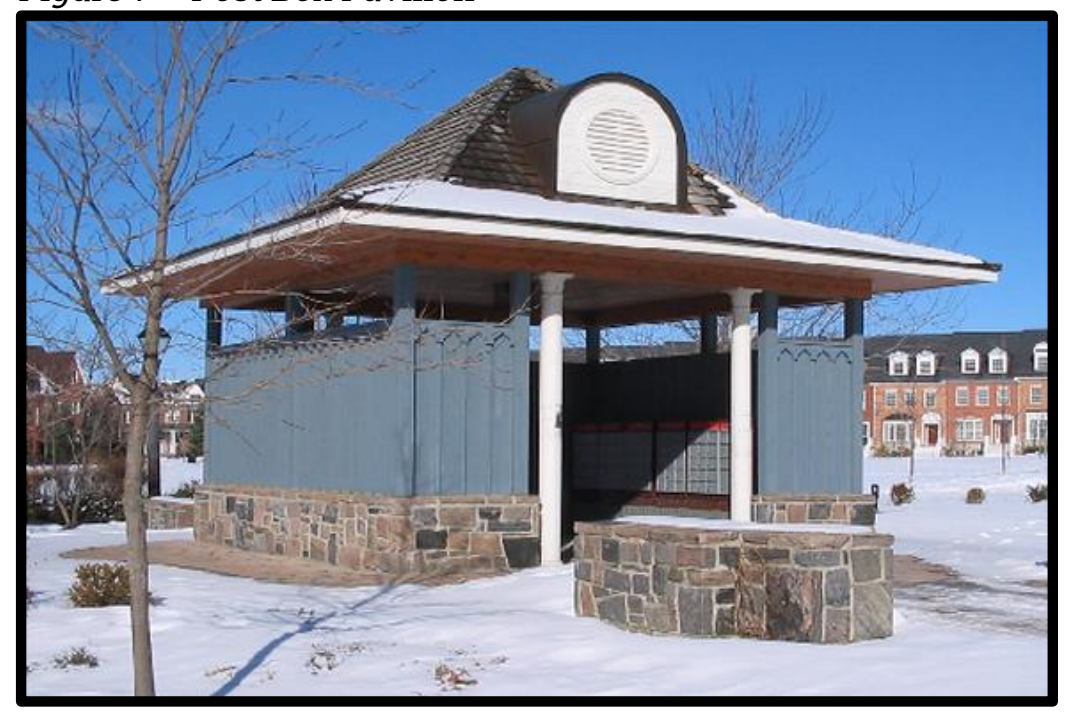

Table 27: ROE Comparison (Landmarks + Places of Activity)

\begin{tabular}{|l|l|}
\hline Base Case & ROE \\
\hline Base Case with Community Post Box & $46.45 \%$ \\
\hline
\end{tabular}

See Appendix 13A and 13B for full assumptions and pro forma analysis.

\section{CONCLUSION}

In conclusion, it is evident that reconfiguring a required element (like a post box) into a community gathering space could provide a daily activity that those with dementia can continue for an extended period of time, giving them an excuse to leave the house and perhaps interact with neighbours. In addition, the change in ROE was negligible $0.1 \%$. This could be added to the Landscape Design of Site Plan and Plan of Subdivision Guidelines and strongly suggested by Staff through the pre-consultation stage to Draft Plan approval stage. It could also be added to the Zoning By-law, when the appropriate massing of residential areas is mentioned. In addition, gateways to the subdivision, while some have identified it as a way to establish neighbourhood identity, is not allowed by the Engineering Standards in the Town of Whitby. 


\subsection{3 - HIERARCHY OF STREETS}

\section{Description}

As part of their push for legibility of streets, Burton \& Mitchell (2006) recommend that cities and neighbourhoods build what they refer to as a hierarchy of streets - creating noticeable differences in built form, roads, sidewalk treatments, etc. for main streets, side streets, lanes and paths (p.62). The reason for this is to build on Core Recommendation \#10 - Varied Urban Form and Architecture, by encouraging an order to streets within an area. This hierarchy of streets, in not only recognizable and familiar to persons with dementia, but it also helps to remind them how to act in that space and what that space is "likely to offer," (p.61). The idea is built off of interior design literature for care homes which seeks to build hallways and spaces that are different, but in a connected manner to help orient residents (p.61).

\section{Literature Review}

Hierarchy of streets was mentioned in 3 out of the 12 articles used for this MRP. From an interior design perspective, the CMHC (2014) report details that it is important to have a "clear hierarchy of spaces, including private, semi-private/semi-public and public spaces helps people with dementia identify different spaces and helps protect their privacy and sense of home," (p.17). Blackman et al. (2003) postulate (based on previous literature) that "The most beneficial urban design is likely to be a visual hierarchy of wider streets for main routes, narrower streets for secondary routes and a variety of street frontages that define formal and informal spaces, buildings and uses," (p.365). A theme throughout the literature is about making places and spaces that are distinct, and therefore less easily confused. This hierarchy is also used as tool for those with dementia in the Brorsson et al. (2014) study, which saw participants taking the quieter narrow streets as a way to avoid congestion and perceived them to be safer (p.9). 


\section{Planning Principles Literature}

\section{"The Image of the City", K. Lynch, 1960}

Lynch notes that "where major paths lacked identity, or were easily confused with one for the other, the entire city image was in difficulty," (p.52). This is one of the primary reasons for creating a hierarchy of streets. Lynch's work looked at several paths within cities, which all had varying characteristics (such as width, uses located along the path, the quality of the small landmarks along it, pedestrian or car congestion, what the path led to etc.) and these characteristics affected the legibility of the path in some way. This variance in paths helped people to understand where they were in the city, such as in a specific district or area. For example, participants noted that people were generally more comfortable taking wider streets as it was perceived to be a main street, automatically (p.50,51). That is why a hierarchy of streets (or even residential neighbourhoods with varying built form types) can improve the legibility and imageability of a space, attaching meaning to a path. Attaching meaning to place helps one to remember and cement navigational cues within our memories (as Lynch notes in his exploration of indigenous peoples) as well as giving us clues as to where that path might lead, or how to behave on it.

\section{ResilientCity "Urban Design Principles"}

Hierarchy of Streets could contribute to achieving the following principles from ResilientCity:

\section{Principle 1 - Density, Diversity and Mix}

In combination with other aspects, the Principle also encourages a variety of building types in order to build a more resilient neighbourhood, and that is what this Core Recommendation seeks to achieve.

\section{Principle 2 - Pedestrians First}

The principle defines a pedestrian as including those with disabilities. In providing a hierarchy of streets within an area, one is potentially contributing to making a neighbourhood more legible for a person with dementia and reminding them how to act in space, and therefore encouraging them to retain their dignity by continuing to walk throughout their neighbourhood. 


\section{Principle 5 - Complete Communities}

In combination with locating uses like retail and the doctor's office within a $500 \mathrm{~m}$ radius of

residential neighbourhoods, this principle speaks of the need to create streets that are enjoyable to walk on. Providing a hierarchy of streets is interesting and keeps the user engaged far more than a monolithic traditional suburb.

Current Planning Frameworks

\begin{tabular}{|c|c|c|c|}
\hline Jurisdiction & Policy & $\begin{array}{l}\text { Applicable } \\
\text { Sections* }\end{array}$ & Summary \\
\hline \multirow[t]{2}{*}{$\begin{array}{l}\text { Province of } \\
\text { Ontario }\end{array}$} & $\begin{array}{l}\text { Provincial Policy } \\
\text { Statement }\end{array}$ & $\begin{array}{l}1.1 \\
1.5 .1 \\
4.6\end{array}$ & $\begin{array}{l}\text { Not explicitly mentioned, but PPS points to the } \\
\text { need to remove barriers for persons with } \\
\text { disabilities as well as older persons. There are } \\
\text { features of typical suburban environments one } \\
\text { could argue that block the rights of someone with } \\
\text { dementia to continue to be able to access their } \\
\text { neighbourhood. A hierarchy of streets has been } \\
\text { discovered by researchers to help those with } \\
\text { dementia know how to act in a space and } \\
\text { remember what the street can offer them. In order } \\
\text { to build a more equitable neighbourhood, creating a } \\
\text { hierarchy of streets can be considered a step } \\
\text { toward fuller participation for those with dementia } \\
\text { into society. }\end{array}$ \\
\hline & $\begin{array}{l}\text { Growth Plan for } \\
\text { the Greater } \\
\text { Golden } \\
\text { Horseshoe }\end{array}$ & $\begin{array}{l}2.2 .2 .1 \mathrm{~d}) \\
2.2 .7 \\
2.22\end{array}$ & $\begin{array}{l}\text { Not explicitly mentioned, but GP instructs that } \\
\text { greenfield development shall be compact, with } \\
\text { urban form and design that supports walking and } \\
\text { creates high quality public space. Hierarchy of } \\
\text { Streets can make public space more interesting } \\
\text { and inviting to others as well. }\end{array}$ \\
\hline $\begin{array}{l}\text { Region of } \\
\text { Durham }\end{array}$ & Official Plan & $\begin{array}{l}2.2 .5 \\
2.3 .5 \\
2.2 .10 \\
4.3 .1 \\
8.1 .4 \\
8.1 .10 \\
8.3 .10 \\
8.2 .1 \\
8 C .1 .6 \\
8 C .2 .9\end{array}$ & $\begin{array}{l}\text { Not explicitly mentioned, but the Regional OP } \\
\text { seeks to encourage area municipalities to create } \\
\text { urban design guidelines. Development is to take } \\
\text { aesthetics into account, promote a sense of } \\
\text { community, encourage pedestrian oriented } \\
\text { environments, and promote compact urban form } \\
\text { that encourages active and public transit. } \\
\text { Hierarchy of Streets can help fulfill some of these } \\
\text { directions. They also mention that areas outside of } \\
\text { the urban boundary shall be single detached and } \\
\text { consistent with the character of the area. This } \\
\text { could potentially be a barrier to Hierarchy of } \\
\text { Streets. }\end{array}$ \\
\hline
\end{tabular}




\begin{tabular}{|c|c|c|c|}
\hline \multirow[t]{4}{*}{$\begin{array}{l}\text { Town of } \\
\text { Whitby }\end{array}$} & Official Plan & $\begin{array}{l}4.2 .3 .1 \\
4.2 .3 .13 \\
4.2 .3 .14 \\
8.1 .3 .1 .7 \\
8.1 .3 .7 .10 \\
10.1 .13 .4 \\
11.8 .7 .2\end{array}$ & $\begin{array}{l}\text { Not explicitly mentioned, but the Whitby OP seeks } \\
\text { to encourage pedestrian facilities that improve } \\
\text { accessibility for persons with disabilities. } \\
\text { Hierarchy of Streets are one way to fulfill these } \\
\text { directions. It also states that a range of tenure } \\
\text { types and built forms shall be encouraged in the } \\
\text { Major Central Area. This could be more effective if } \\
\text { it was applied to all areas within the urban } \\
\text { boundary. In addition, } 4.2 .3 .1 \text { could pose a barrier as } \\
\text { it severely limits what can be built with a } \\
\text { residential area. }\end{array}$ \\
\hline & $\begin{array}{l}\text { Zoning By-law } \\
2585\end{array}$ & $\mathrm{n} / \mathrm{a}$ & \\
\hline & $\begin{array}{l}\text { Engineering } \\
\text { Standards }\end{array}$ & $\mathrm{n} / \mathrm{a}$ & \\
\hline & $\begin{array}{l}\text { Landscape Plan } \\
\text { Guidelines }\end{array}$ & $\mathrm{n} / \mathrm{a}$ & \\
\hline
\end{tabular}

*For a full list of the exact sections detailed in this Table, please see Appendix 19 - Current Planning Frameworks List

Town of Whitby Accessibility Standards, 2005

Hierarchy of Streets are not mentioned in this document.

\section{How can this be measured?}

The overwhelming majority of subdivisions in Whitby are entirely residential, consisting of single detached homes that are of a similar style. While Whitby does have commercial areas along corridors like Thickson Road and a downtown area around Dundas and Brock Street, subdivisions are not typically designed to have a hierarchy of streets or to be different from one to the next. Within the Regional Official Plan however, residential areas, referred to as 'Living Areas' are permitted other uses such as small format retail and doctor's offices. This could allow developers to be creative and provide uses other than residential (such as following Core Recommendation \#1Mixed Use Areas), which could contribute to making a hierarchy of streets. In addition, this design recommendation is related to \#10 - Varied Urban Form and Architecture, in that part of the battle of having streets that are not identical is encouraging developers to build different style houses in one subdivision, instead of half a dozen models of the same design. Within the typical residential subdivision in Whitby (and in much of the GTA), the treatment used for streets, in addition to housing design are nearly identical and hard to navigate for even an able-minded person. Since 
this core recommendation and \#10 - Varied Urban Form and Architecture are closely related, this MRP will use the same method of measurement. (See Appendix 7A and 7B for the full pro forma analysis and assumptions).

Another way to encourage the different treatment of streets within a subdivision (and provide legibility) would be to plant different kinds of trees on different streets, such as on lots or within buffer zones. This cost is already factored into the base case subdivision, it is just a matter of Town Staff encouraging a developer to do it. Lastly, in order to encourage this hierarchy further, the Town of Whitby and Region of Durham could consider allowing a smaller Right-of-Way width/road size, in order to allow the developer to build different sizes of road and therefore increase overall legibility of the community.

\section{How can this be economically quantified?}

Please see \#10 - Varied Urban Form and Architecture for the pro forma analysis.

\section{CONCLUSION}

In conclusion, it is evident that designing neighbourhoods that includes variety in built form with benefit everyone in society in regards to orientation, including those with dementia. A hierarchy of streets adds to legibility, in reminding people with dementia how to act in certain situations. In addition, the change in ROE was negligible $0.07 \%$. This could be added to the Landscape Design of Site Plan and Plan of Subdivision Guidelines and strongly suggested by Staff through the pre-consultation stage to Draft Plan approval stage. It could also be added to the Official Plan or Zoning By-law, when the appropriate massing of residential areas is mentioned.

This recommendation is in contrast to what would be requested by the municipality in terms of urban design. The Town of Whitby encourages the subdivisions to have a distinct character, meaning that all the streets within the subdivision are populated by variations of the same style, in order to avoid a scattered look (Personal Communication, PC1, March 5, 2015). One could make the 
case however, for having similar style homes but making sure the streets are discernible through using different density types and perhaps different finishes.

\subsection{4 - DISTINCTIVE FEATURES AT JUNCTIONS}

\section{Description}

While Burton \& Mitchell (2006) advocate for short blocks, Irregular gird patterns and winding streets as the key features of a dementia-friendly street layout, the reality is that as a consequence of having more connected streets, there are more intersections. Road intersections were according to the findings of the study, one of the most disorientating places in the neighbourhood, as it was here were participants had to make a decision about which way to turn and often they were faced with four visually similar routes (p.70). There are however, a few ways to ameliorate this such as:

- Creating shorter streets which allow participants to "see their route through," (p.70).

- Making long streets winding to allow for a "change in scenery," (p.70)

- Building landmarks (that end up remaining for a long amount of time) as well as street furniture and trees placed at decision-points (like junctions) and where one's line of sight ends (p.75).

Burton \& Mitchell's (2006) study supported these findings, stating that wayfinding cues are often found at the end of a participant's line of vision. As cited in Burton \& Mitchell (2006), Golledge (1991) found that people made fewer wayfinding mistakes when "anchor points were positioned at places where complex decisions are required," (p.86). These anchor points could be in the form of aesthetic (water fountains, potted plants, trees, gardens) or practical (bus stop, post box, public seating) environmental features - both are effective means of helping a person to orient themselves and navigate through a familiar neighbourhood (p.86).

\section{Literature Review}

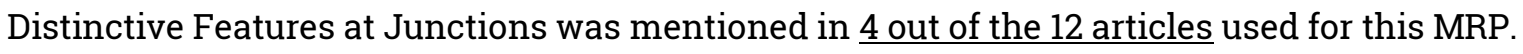
This Core Recommendation is closely related to Recommendation \#12 - Landmarks and Places of Activity, which encourage the building of 'visual cues' through various methods to help those with 
dementia situate themselves in space (Mitchell et al., 3002, p.624). While the mentioning of landmarks within the literature was common, there was only one article that explicitly recommended placing these cues at junctions. CMHC (2014) note designers (of indoor environments) should "Consider the placement of cueing devices or 'landmarks' to assist with place recognition and orientation, including at decision-points where navigational choices must be made, such as at doorways, corners or intersections of corridors," (p.37).

Even though only one article explicitly recommended this, it would make sense to locate a majority of landmarks at street intersections, as these are spaces where the 'line of sight' often ends and where decisions have to be made about directions (as opposed to walking on a straight street). In addition, this is probably where the majority of signs would be located. Lastly, since this is a residential subdivision, it can be assumed that landmarks are more likely to be placed at junctions to be accessible to more people.

\section{Planning Principles Literature}

\section{"The Image of the City", K. Lynch, 1960}

Junctions, where a number of paths meet form one of Lynch's five elements - nodes. Lynch (1960) describes nodes as "strategic foci" within the city landscape, as this is where "people heighten their attention...and perceive nearby elements with more than normal clarity," (p.72, 73). The reason for this is that decisions have to be made at junctions, and humans respond instinctively by being on alert. This action was repeated so often in his interviews that Lynch concluded that "elements located at junctions may automatically be assumed to derive special prominence from their location," (p.73). In addition, when people were asked about a point on a habitual trip when they arrived in downtown Boston, they always mentioned a junction of transportation - be it an exit off a highway, a traffic circle or railroad station (p.73). Nodes thus have the potential to be very prominent pieces within a city and help people navigate, if it is memorable as well as intensifies the character of the area around it (p.77). In addition, the Small Block, Irregular Grid And Winding 
Streets Pattern can be augmented by features at junctions, as Lynch mentions, "...more abrupt directional shifts may enhance visual clarity by limiting the spatial corridor and by providing prominent sites for distinctive structures," (p.56). Lastly, Lynch advises that landmarks have more impact on the legibility of a city when located at a junction and it increases its likelihood of being remembered (p.81).

\section{ResilientCity "Urban Design Principles"}

Distinctive Features at Junctions could contribute to achieving the following principles from

ResilientCity:

\section{Principle 2 - Pedestrians First}

The principle defines a pedestrian as including those with disabilities, and prioritizing their needs over the automobile. In building distinctive features at junctions in community, one is making an environment more legible for persons with dementia, as well as for able minded persons.

\section{Principle 4 - Place-making}

Inserting distinctive features at junctions into a subdivision may not only add legibility for those with dementia, but also represents a step towards this principle of building places that can have meaning attached to them.

\section{Principle 5 - Complete Communities}

In combination with locating uses like retail and the doctor's office within a $500 \mathrm{~m}$ radius of residential neighbourhoods, this principle speaks of the need to create streets that facilitate walking. For those with dementia, having distinctive features at junctions to help them retain their dignity by enabling them to continue to walk throughout their neighbourhood. 
Current Planning Frameworks

\begin{tabular}{|c|c|c|c|}
\hline Jurisdiction & Policy & $\begin{array}{l}\text { Applicable } \\
\text { Sections* }\end{array}$ & Summary \\
\hline \multirow[t]{2}{*}{$\begin{array}{l}\text { Province of } \\
\text { Ontario }\end{array}$} & $\begin{array}{l}\text { Provincial Policy } \\
\text { Statement }\end{array}$ & $\begin{array}{l}1.1 \\
1.5 .1 \\
4.6\end{array}$ & $\begin{array}{l}\text { Not explicitly mentioned, but PPS points to the } \\
\text { need to remove barriers for persons with } \\
\text { disabilities as well as older persons. There are } \\
\text { features of typical suburban environments one } \\
\text { could argue that block the rights of someone with } \\
\text { dementia to continue to be able to access their } \\
\text { neighbourhood. A lack of identifiable and familiar } \\
\text { landmarks to aid in wayfinding a decision points, } \\
\text { like junctions, have been identified as a barrier to } \\
\text { persons with dementia in the literature. Removing } \\
\text { these barriers by installing practical and/or } \\
\text { aesthetic landmarks is a step toward fuller } \\
\text { participation for those with dementia into society. }\end{array}$ \\
\hline & $\begin{array}{l}\text { Growth Plan for } \\
\text { the Greater } \\
\text { Golden } \\
\text { Horseshoe }\end{array}$ & $\begin{array}{l}2.2 .2 .1 \mathrm{~d}) \\
2.2 .7 \\
2.22\end{array}$ & $\begin{array}{l}\text { Not explicitly mentioned, but GP instructs that } \\
\text { greenfield development shall be compact, with } \\
\text { urban form and design that supports walking and } \\
\text { creates high quality public space. Distinctive } \\
\text { Features at Junctions may encourage those with } \\
\text { dementia to walk more often as they will probably } \\
\text { be able to wayfind with less difficulty. Landmarks } \\
\text { also are more aesthetically pleasing and } \\
\text { contributes to building high quality public space. }\end{array}$ \\
\hline $\begin{array}{l}\text { Region of } \\
\text { Durham }\end{array}$ & Official Plan & $\begin{array}{l}2.2 .5 \\
2.3 .5 \\
2.2 .10 \\
8.1 .4 \\
8.1 .10 \\
8.2 .1 \\
8 C .1 .6 \\
8 C .2 .9\end{array}$ & $\begin{array}{l}\text { Not explicitly mentioned, but the Regional OP } \\
\text { seeks to encourage area municipalities to create } \\
\text { urban design guidelines. Development is to take } \\
\text { aesthetics into account, promote a sense of } \\
\text { community, encourage pedestrian oriented } \\
\text { environments, promote tree planting and promote } \\
\text { compact urban form that encourages active transit. } \\
\text { Distinct Features at Junctions can help fulfill some } \\
\text { of these directions, especially in restoring a } \\
\text { method of wayfinding that human beings are more } \\
\text { adept at using. }\end{array}$ \\
\hline \multirow[t]{3}{*}{$\begin{array}{l}\text { Town of } \\
\text { Whitby }\end{array}$} & Official Plan & $\begin{array}{l}8 \cdot 1 \cdot 3 \cdot 1.7 \\
8 \cdot 1 \cdot 3 \cdot 7.10 \\
10.1 .13 .4\end{array}$ & $\begin{array}{l}\text { Not explicitly mentioned, but the Whitby OP seeks } \\
\text { to encourage pedestrian facilities that improve } \\
\text { accessibility for persons with disabilities. } \\
\text { Providing Distinctive Features at Junctions is one } \\
\text { way to achieve this direction. The OP already } \\
\text { encourages a grid network, so there are many } \\
\text { opportunities to build distinctive features at } \\
\text { junctions. }\end{array}$ \\
\hline & $\begin{array}{l}\text { Zoning By-law } \\
2585\end{array}$ & $\mathrm{n} / \mathrm{a}$ & \\
\hline & $\begin{array}{l}\text { Engineering } \\
\text { Standards }\end{array}$ & $\begin{array}{l}\text { REGION } \\
\text { STD S-502 }\end{array}$ & $\begin{array}{l}\text { Medians are governed by Regional Engineering } \\
\text { Standards }\end{array}$ \\
\hline
\end{tabular}




\begin{tabular}{|l|l|l|l|}
\hline & $\begin{array}{l}\text { Landscape Plan } \\
\text { Guidelines }\end{array}$ & 3.3 & $\begin{array}{l}\text { The Guidelines only require a developer to submit } \\
\text { plans, but provides no guidance on what to include } \\
\text { at intersections. The use of masonry pillars and } \\
\text { gateways is discouraged within Subdivision } \\
\text { Developments in the Town of Whitby and are not } \\
\text { permitted within the public Right-of-way. }\end{array}$ \\
\hline
\end{tabular}

*For a full list of the exact sections detailed in this Table, please see Appendix 19 - Current Planning Frameworks List

Town of Whitby Accessibility Standards, 2005

While these Standards do not include a section about the importance of including landmarks

in areas, it does discuss how to incorporate them so that they comply with accessibility needs.

Many of the distinctive features at junctions that might be proposed by this section are included in

what Section 4.3.17 of the Accessibility Standards outlines as street furniture- benches, post boxes, light standards, garbage bins, planters, signs and vending machines. The section details how to include street furniture on pathways, including that a furniture piece (such as a bench) must not block the required sidewalk width of $1.83 \mathrm{~m}$, and should be located securely on an amenity strip measuring at least $60.1 \mathrm{~cm}$ wide (and probably made of concrete). This amenity strip could be incorporated into the buffer zone already being built in most subdivisions in Whitby, but is not required (as these standards are optional for private developers). In addition, Section 4.3.14 notes that providing flowers along routes can prove to be useful visual cues for those who are visually impaired as well as providing landmarks. They do provide guidelines for what an accessible plant bed might look like: It should be raised at least $46 \mathrm{~cm}$ off the ground and be located along a pedestrian route. Lastly, when planters are installed on a sidewalk, they must have a $7.5 \mathrm{~cm}$ high curb around them, as these are cane-detectable (for the visually impaired).

\section{How can this be measured?}

Since many of the other Core Recommendations (such as bus stops, benches, and signs etc.) could be located at junctions in order to provide legibility, the following extra costs were calculated in Table 30. 
Table 30: Costs for Distinctive Features at Junctions

\begin{tabular}{|c|c|c|}
\hline Line Item & Assumption & Number \\
\hline Landscaped Median (3m x 3m) & $\$ 375$ each & $\begin{array}{l}\text { One per external intersection } \\
\text { as a means to slow down } \\
\text { traffic. }\end{array}$ \\
\hline $\begin{array}{l}\text { Flower Pots with Plantings (3ft } \\
\mathrm{x} 3 \mathrm{ft} \text { ) }\end{array}$ & $\$ 1500$ & Two per internal intersection. \\
\hline Trellis & $\$ 15,000$ per trellis & One per development. \\
\hline
\end{tabular}

How can this be economically quantified?

Table 31: ROE Comparison (Distinctive Features at Junctions)

\begin{tabular}{|ll|}
\hline Base Case & ROE \\
\hline Base Case with Distinctive Features at Junctions & $46.45 \%$ \\
\hline
\end{tabular}

See Appendix 14A and 14B for the full list of assumptions and pro forma.

\section{CONCLUSION}

In conclusion, it is evident that providing distinctive features at junctions could benefit a majority of people in society (including those with dementia), helping them to navigate a normally monolithic and difficult subdivision. In addition, the change in ROE was negligible $0.11 \%$. This could be added to the Landscape Design of Site Plan and Plan of Subdivision Guidelines and strongly suggested by Staff through the pre-consultation stage to Draft Plan approval stage. It could also be added to the Official Plan or Zoning By-law, when the appropriate massing of residential areas is mentioned.

\subsection{5 - BUILDINGS WITH OBVIOUS ENTRANCES}

\section{Description}

Burton \& Mitchell (2006) note that persons with dementia have difficulty in responding to some cues in the environment around them, such as:

- The use of buildings

- The location of entrances

- The behaviour that is expected of them in certain places

- The intentions of the people around them (p.37) 
In addition, people with dementia are able to interpret various styles of buildings (modern or traditional) but only if their function is clear from its design (p.37). People with dementia struggle with identifying spaces in which their use is ambiguous, such as buildings with blank facades or unclear entrances (p.54). This could actually cause people with dementia to trespass onto private property without knowing it or make them "reluctant to use public places," (p.54). In response to this, they call for the design of buildings that "provide clear, unambiguous and understandable signals as to the building's identity, use and entrances," (p.87).

\section{Literature Review}

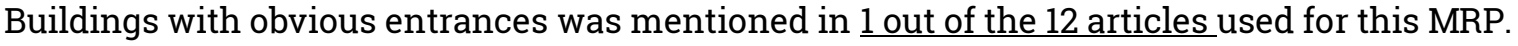
Blackman et al. (2003) postulate (based on previous literature) that "The most beneficial urban design is likely to be a visual hierarchy of wider streets for main routes, narrower streets for secondary routes and a variety of street frontages that define formal and informal spaces, buildings and uses," (p.365). That being said, only one of the articles explicitly mentions the need to design the entrances of buildings in an obvious way is the CMHC Report. CMHC (2014) says that environments should "Provide clear routes and entrances," (p.19), which makes sense from an internal and outdoor design perspective. While none of the other articles mentioned the use of obvious entrances, Blackman et al. (2007) found that using simple signage to identify the purpose of the building was just as effective as an obvious entrance (p.818).

\section{Planning Principles Literature}

\section{"The Image of the City", K. Lynch, 1960}

While Lynch (1960) does not explicitly state that entrances to buildings must be obvious, he does mention entrances to certain buildings as he evaluates a select few American cities as nodes (p.143), which are "the strategic foci into which the observer can enter typically either junction of paths or concentrations of some characteristic," (p.72). This could indicate that entrances to 
prominent buildings act like roadway intersections in representing a decision-point, which makes

their legibility important to someone with dementia.

ResilientCity "Urban Design Principles"

Buildings with obvious entrances could contribute to achieving the following principle from

ResilientCity:

Principle 2 - Pedestrians First

The principle defines a pedestrian as including those with disabilities, and prioritizing their needs

over the automobile. In constructing buildings with obvious entrances in community, one is

making an environment more legible for persons with dementia.

\begin{tabular}{|c|c|c|c|}
\hline \multicolumn{4}{|c|}{ Table 32: Buildings with Obvious Entrances } \\
\hline Jurisdiction & Policy & $\begin{array}{l}\text { Applicable } \\
\text { Sections* }\end{array}$ & Summary \\
\hline \multirow[t]{2}{*}{$\begin{array}{l}\text { Province of } \\
\text { Ontario }\end{array}$} & $\begin{array}{l}\text { Provincial Policy } \\
\text { Statement }\end{array}$ & $\begin{array}{l}1.1 \\
1.5 .1 \\
4.6\end{array}$ & $\begin{array}{l}\text { Not explicitly mentioned, but PPS points to the } \\
\text { need to remove barriers for persons with } \\
\text { disabilities as well as older persons. There are } \\
\text { features of typical suburban environments one } \\
\text { could argue that block the rights of someone with } \\
\text { dementia to continue to be able to access their } \\
\text { neighbourhood. Buildings lacking obvious } \\
\text { entrances have been identified as a barrier to } \\
\text { persons with dementia in the literature. Removing } \\
\text { these barriers by installing extra features on } \\
\text { entrances to make sure a person feels independent } \\
\text { when entering is a step toward fuller participation } \\
\text { for those with dementia into society. }\end{array}$ \\
\hline & $\begin{array}{l}\text { Growth Plan for } \\
\text { the Greater } \\
\text { Golden } \\
\text { Horseshoe }\end{array}$ & $\begin{array}{l}2.2 .2 .1 \text { d) } \\
2.2 .7 \\
2.22\end{array}$ & $\begin{array}{l}\text { Not explicitly mentioned, but GP instructs that } \\
\text { greenfield development shall be compact, with } \\
\text { urban form and design that supports walking and } \\
\text { creates high quality public space. Buildings with } \\
\text { Obvious Entrances will encourage walking for } \\
\text { those with dementia (as it may give them more } \\
\text { confidence when walking) and may make the } \\
\text { pedestrian environment more inviting to others. }\end{array}$ \\
\hline $\begin{array}{l}\text { Region of } \\
\text { Durham }\end{array}$ & Official Plan & $\begin{array}{l}2.2 .5 \\
2.3 .5 \\
2.2 .10 \\
8.1 .4 \\
8.1 .10 \\
8 C .1 .6 \\
\text { 8C.2.9 }\end{array}$ & $\begin{array}{l}\text { Not explicitly mentioned, but the Regional OP } \\
\text { seeks to encourage area municipalities to create } \\
\text { urban design guidelines. Development is to take } \\
\text { aesthetics into account, promote a sense of } \\
\text { community, encourage pedestrian oriented } \\
\text { environments, and promote compact urban form } \\
\text { that encourages active transit. Buildings with } \\
\text { Obvious Entrances can help fulfill some of these } \\
\text { directions. }\end{array}$ \\
\hline
\end{tabular}




\begin{tabular}{|l|l|l|l|}
\hline $\begin{array}{l}\text { Town of } \\
\text { Whitby }\end{array}$ & Official Plan & 10.1 .13 .4 & $\begin{array}{l}\text { Not explicitly mentioned, but the Whitby OP seeks } \\
\text { to encourage pedestrian facilities that improve } \\
\text { accessibility for persons with disabilities. } \\
\text { Buildings with Obvious Entrances are one way to } \\
\text { fulfill these directions. }\end{array}$ \\
\cline { 2 - 4 } & $\begin{array}{l}\text { Zoning By-law } \\
2585\end{array}$ & $\mathrm{n} / \mathrm{a}$ & \\
\cline { 2 - 4 } & $\begin{array}{l}\text { Engineering } \\
\text { Standards }\end{array}$ & $\mathrm{n} / \mathrm{a}$ & \\
\cline { 2 - 4 } & $\begin{array}{l}\text { Landscape Plan } \\
\text { Guidelines }\end{array}$ & $\mathrm{n} / \mathrm{a}$ & \\
\hline
\end{tabular}

*For a full list of the exact sections detailed in this Table, please see Appendix 19 - Current Planning Frameworks List

Town of Whitby Accessibility Standards, 2005

Section 4.1.5 states that the way one designs entrances to buildings has a "direct influence on the independence and dignity of everyone entering or exiting a facility." The document mentions that canopies over entrances are a good way to provide protection from the elements, as well as make the entrance more obvious to someone with a cognitive disability. It should be highlighted that this is one of two times that cognitive disability is mentioned at all in this document. The other is in regards to persons with cognitive disabilities perhaps having difficulty with the timing of automatic doors (Section 4.1.6).

How can this be measured/how can this be economically quantified?

Since the majority of buildings in subdivisions in Whitby have obvious entrances, and this was more of a direct built form issue, this was not calculated.

\section{CONCLUSION}

Having buildings with obvious entrances is important within neighbourhoods, perhaps most importantly in regards to facilities or other non-residential uses. This Core Recommendation, while hard to calculate for this project, may be useful when evaluating the dementia-friendliness of already established areas or facilities. 


\subsection{6 - BUILDINGS THAT REFLECT USE}

\section{Description}

Burton \& Mitchell (2006) note that persons with dementia have difficulty in responding to some cues in the environment around them, such as:

- The use of buildings

- The location of entrances

- The behaviour that is expected of them in certain places

- The intentions of the people around them (p.37)

In addition, people with dementia are able to interpret various styles of buildings (modern or traditional) but only if their function is clear from its design (p.37). People with dementia struggle with identifying spaces in which their use is ambiguous, such as buildings with blank facades or unclear entrances (p.54). This could actually cause people with dementia to trespass onto private property without knowing it or make them "reluctant to use public places," (p.54). In response to this, they call for the design of buildings that "provide clear, unambiguous and understandable signals as to the building's identity, use and entrances," (p.87).

\section{Literature Review}

Buildings that reflect use were mentioned in 3 out of the 12 articles used for this MRP. While none of the selected literature specifically mentioned the need to design buildings to reflect its use, the CMHC (2014) report emphasizes the need to include objects that are "familiar from a person's past or intuitive to use," within long term care facilities (p.19). Two articles did mention the effect of a changing landscape on those with dementia (such as infill). That being said, this was more in regards to the changing nature of landmarks that one might use to wayfind, rather than the traditionalist design of the building. One way to cope with infill changes was identified by an informant in the Brittain et al. (2010) study who would look at old photographs of his neighbourhood and use them to compare to the new buildings that had taken their place. 


\section{Planning Principles Literature}

"The Image of the City", K. Lynch, 1960

Buildings that reflect use were not mentioned in this work.

\section{ResilientCity "Urban Design Principles"}

Buildings that reflect use could contribute to achieving the following principle from ResilientCity:

Principle 2 - Pedestrians First

The principle defines a pedestrian as including those with disabilities, and prioritizing their needs

over the automobile. In constructing buildings that reflect use in community, one is making an

environment more legible for persons with dementia.

\section{Current Planning Frameworks}

\begin{tabular}{|c|c|c|c|}
\hline Jurisdiction & Policy & $\begin{array}{l}\text { Applicable } \\
\text { Sections* }\end{array}$ & Summary \\
\hline \multirow[t]{2}{*}{$\begin{array}{l}\text { Province of } \\
\text { Ontario }\end{array}$} & $\begin{array}{l}\text { Provincial Policy } \\
\text { Statement }\end{array}$ & $\begin{array}{l}1.1 \\
1.5 .1 \\
4.6\end{array}$ & $\begin{array}{l}\text { Not explicitly mentioned, but PPS points to the } \\
\text { need to remove barriers for persons with } \\
\text { disabilities as well as older persons. There are } \\
\text { features of typical suburban environments one } \\
\text { could argue that block the rights of someone with } \\
\text { dementia to continue to be able to access their } \\
\text { neighbourhood. Buildings that do not reflect their } \\
\text { use have been identified as a barrier to persons } \\
\text { with dementia in the literature. Removing these } \\
\text { barriers by ensuring that houses resemble (at least } \\
\text { in part) a traditional home or that retail stores } \\
\text { retain window displays, is a step toward fuller } \\
\text { participation for those with dementia into society. }\end{array}$ \\
\hline & $\begin{array}{l}\text { Growth Plan for } \\
\text { the Greater } \\
\text { Golden } \\
\text { Horseshoe }\end{array}$ & $\begin{array}{l}2.2 .2 .1 \mathrm{~d}) \\
2.2 .7 \\
2.22\end{array}$ & $\begin{array}{l}\text { Not explicitly mentioned, but GP instructs that } \\
\text { greenfield development shall be compact, with } \\
\text { urban form and design that supports walking and } \\
\text { creates high quality public space. Buildings that } \\
\text { reflect their use will encourage walking for those } \\
\text { with dementia (as it may give them more } \\
\text { confidence when walking) and may make the } \\
\text { pedestrian environment more inviting to others. }\end{array}$ \\
\hline $\begin{array}{l}\text { Region of } \\
\text { Durham }\end{array}$ & Official Plan & $\begin{array}{l}2.2 .5 \\
2.3 .5 \\
2.2 .10 \\
8.1 .4 \\
8.1 .10 \\
8 C .1 .6 \\
8 C .2 .9\end{array}$ & $\begin{array}{l}\text { Not explicitly mentioned, but the Regional OP } \\
\text { seeks to encourage area municipalities to create } \\
\text { urban design guidelines. Development is to take } \\
\text { aesthetics into account, promote a sense of } \\
\text { community, encourage pedestrian oriented } \\
\text { environments, and promote compact urban form } \\
\text { that encourages active transit. Buildings that } \\
\text { reflect their use can help fulfill some of these } \\
\text { directions. }\end{array}$ \\
\hline
\end{tabular}




\begin{tabular}{|l|l|l|l|}
\hline $\begin{array}{l}\text { Town of } \\
\text { Whitby }\end{array}$ & Official Plan & $\begin{array}{l}8.1 .3 .7 .10 \\
10.1 .13 .4\end{array}$ & $\begin{array}{l}\text { Not explicitly mentioned, but the Whitby OP seeks } \\
\text { to encourage pedestrian facilities that improve } \\
\text { accessibility for persons with disabilities. } \\
\text { Buildings that reflect their use are one way to fulfill } \\
\text { these directions. }\end{array}$ \\
\cline { 2 - 4 } & $\begin{array}{l}\text { Zoning By-law } \\
2585\end{array}$ & $\mathrm{n} / \mathrm{a}$ & \\
\cline { 2 - 4 } & $\begin{array}{l}\text { Engineering } \\
\text { Standards }\end{array}$ & $\mathrm{n} / \mathrm{a}$ & \\
\cline { 2 - 4 } & $\begin{array}{l}\text { Landscape Plan } \\
\text { Guidelines }\end{array}$ & $\mathrm{n} / \mathrm{a}$ & \\
\hline
\end{tabular}

*For a full list of the exact sections detailed in this Table, please see Appendix 19 - Current Planning Frameworks List

Town of Whitby Accessibility Standards, 2005

Buildings that reflect use are not mentioned in this document, however it does mention that entrances to buildings should be obvious. For more information on entrances, please see \#16 Buildings with Obvious Entrances.

How can this be measured/how can this be economically quantified?

Since the majority of buildings in subdivisions in Whitby have houses that look similar to houses from the 1950s, this was not calculated. This is also something that the Town could look into encouraging, however since it is the norm, it is hard to understand the difference.

\section{CONCLUSION}

Having buildings that reflect use is important within neighbourhoods, perhaps most importantly in regards to infill development. This Core Recommendation, while hard to calculate for this project, may be useful when evaluating the dementia-friendliness of already established areas.

\subsection{7 - GENTLY WINDING STREETS}

\section{Description}

Burton \& Mitchell (2006) describe the best possible street layout as an "Irregular grid pattern with corners greater than 90 degrees and gently winding streets where the vista slowly opens up as one walks along provides an interesting and legible street layout for older people. It also helps people to feel safer than a street with blind bends where one cannot tell what might be around the 
corner," (p.125). It should be noted that this pattern does not include cul-de-sacs, as these are cited as detrimental to wayfinding. Please see Core Recommendation \#6 - Short Blocks and Irregular Grid for a more in depth exploration of the Burton \& Mitchell (2006) study of this design recommendation.

\section{Literature Review}

Gently winding streets were mentioned in 2 out of the 12 articles used for this MRP. Mitchell et al. (2003) discuss the use of 'wandering paths' in care homes and the use of circular hallways as a way to allow residents to wander safely, without impediment and reduce the feelings of anxiety associated with hitting a dead end (p.623). Blackman et al. (2003) echo this by stating "short, direct routes without dead ends and small explicit spaces without sharp corners are likely to be less disabling," (p.365). While this method may work within care settings, it goes unmentioned in the other literature on dementia and the outdoor environment (beyond the long term care facility setting). In addition, while Burton \& Mitchell (2006) report that these gently curving streets may have been found to be more interesting, they can also block the view of the end of a street, which might be used as a visual cue for wayfinding.

\section{Planning Principles Literature}

\section{"The Image of the City", K. Lynch, 1960}

Paths are one of Lynch's five symbols that make up a city and make up the routes by which people move around the city. Paths were identified in interviews as "the predominant city elements," and for people who knew the city best, the path was made up of "small landmarks." (p.49). Curves in streets were identified by Lynch's informants are sometimes misleading (p.56). He also notes that the following behaviour of participants, "typical of the constant tendency of the subjects to impose regularity on their surroundings. Unless obvious evidence refuted it, they tried to organize paths into geometrical networks, disregarding curves and non-perpendicular intersections," (p.61). This means that when designing a street layout, one would have to strike a 
balance between providing an interesting walk along longer streets and curving the road so much

that it disorients the person to the direction they are headed.

ResisilientCity.org "Urban Design Principles"

Principle 4 - Place-making

The intent of gently winding streets fits best with this Principle, as the purpose of the Core

Recommendation is to provide a streetscape that is interesting. Winding streets also happen to be a recommendation that is preferred by people with dementia as it forces them to concentrate and therefore make them less likely to get lost.

\section{Current Planning Frameworks}

\begin{tabular}{|c|c|c|c|}
\hline \multicolumn{4}{|c|}{ Table 33: Gently Winding Streets } \\
\hline Jurisdiction & Policy & $\begin{array}{l}\text { Applicable } \\
\text { Sections* }\end{array}$ & Summary \\
\hline \multirow[t]{2}{*}{$\begin{array}{l}\text { Province of } \\
\text { Ontario }\end{array}$} & $\begin{array}{l}\text { Provincial Policy } \\
\text { Statement }\end{array}$ & $\begin{array}{l}1.1 \\
1.5 .1 \\
4.6\end{array}$ & $\begin{array}{l}\text { The PPS points to the need to remove barriers for } \\
\text { persons with disabilities as well as older persons. } \\
\text { There are features of typical suburban } \\
\text { environments one could argue that block the rights } \\
\text { of someone with dementia to continue to be able to } \\
\text { access their neighbourhood, including a lack of } \\
\text { places to sit and rest. Cul-de-sacs, long and dead } \\
\text { end streets have been identified as barriers by } \\
\text { persons with dementia in their ability to access the } \\
\text { outdoor world. Removing these barriers by creating } \\
\text { a legible street pattern that takes into account their } \\
\text { specialized needs, while doing a better job of } \\
\text { connecting the neighbourhood is a step toward } \\
\text { fuller participation for those with dementia into } \\
\text { society. }\end{array}$ \\
\hline & $\begin{array}{l}\text { Growth Plan for } \\
\text { the Greater } \\
\text { Golden } \\
\text { Horseshoe }\end{array}$ & $\begin{array}{l}2.2 .2 .1 \mathrm{~d}) \\
2.2 .7 \\
2.22\end{array}$ & $\begin{array}{l}\text { GP instructs that greenfield development shall be } \\
\text { compact, with urban form and design that supports } \\
\text { walking and creates high quality public space. } \\
\text { Gently Winding Streets could contribute to } \\
\text { fulfilling these directions. }\end{array}$ \\
\hline $\begin{array}{l}\text { Region of } \\
\text { Durham }\end{array}$ & Official Plan & $\begin{array}{l}2.2 .10 \\
8.1 .4 \\
8.1 .10 \\
8.3 .10 \\
8.2 .1 \\
8 C .1 .6 \\
8 C .2 .9\end{array}$ & $\begin{array}{l}\text { Not explicitly mentioned, but the Regional OP } \\
\text { seeks to encourage area municipalities to create } \\
\text { urban design guidelines. Development is to take } \\
\text { aesthetics into account, promote a sense of } \\
\text { community, encourage pedestrian oriented } \\
\text { environments, and promote compact urban form } \\
\text { that encourages active transit. When combined } \\
\text { with Small blocks and Irregular Grid Pattern, } \\
\text { Gently Winding Streets can build a more } \\
\text { connected neighbourhood and therefore help fulfill } \\
\text { some of these directions. }\end{array}$ \\
\hline
\end{tabular}




\begin{tabular}{|l|l|l|l|}
\hline $\begin{array}{l}\text { Town of } \\
\text { Whitby }\end{array}$ & Official Plan & $\begin{array}{l}8.1 .3 .1 .7 \\
8.1 .3 .7 .10 \\
10.1 .13 .4\end{array}$ & $\begin{array}{l}\text { The Whitby OP seeks to encourage pedestrian } \\
\text { facilities that improve accessibility for persons } \\
\text { with disabilities as well as encouraging a grid- } \\
\text { oriented street network. When combined with } \\
\text { Small Blocks and Irregular Grid, Gently Winding } \\
\text { Streets is one way to fulfill these directions. }\end{array}$ \\
\cline { 3 - 4 } & $\begin{array}{l}\text { Zoning By-law } \\
2585\end{array}$ & $\mathrm{n} / \mathrm{a}$ & \\
\cline { 2 - 4 } & $\begin{array}{l}\text { Engineering } \\
\text { Standards }\end{array}$ & $\mathrm{n} / \mathrm{a}$ & \\
\cline { 2 - 4 } & $\begin{array}{l}\text { Landscape Plan } \\
\text { Guidelines }\end{array}$ & $\mathrm{n} / \mathrm{a}$ & \\
\hline
\end{tabular}

*For a full list of the exact sections detailed in this Table, please see Appendix 19 - Current Planning Frameworks List

Town of Whitby Accessibility Standards, 2005

Gently Winding Streets are not mentioned specifically in this document. In addition, there are no

directions on how to create a layout of paths that might be more accessible to a variety of users.

How can this be measured? How can this be economically quantified?

This core recommendation was combined with \#6 - Small Blocks and Irregular Grid. See

Section 3.6 for a more detailed analysis of the effect on ROE and how it was calculated.

\section{CONCLUSION}

Adding a "winding element" to longer streets is a possible pattern for a street layout, when

combined with the small blocks and Irregular grid pattern. It is evident that this kind of street pattern could benefit a majority of people in society, including those with dementia. The change in ROE was substantial at $12.1 \%$. While this may be a large difference, it is worth noting that the ROE is still well above what a developer considers an appropriate rate of return (15-20\%). For detailed results and implementation, see Section 4.6 Small Blocks and Irregular Grid.

The next chapter will examine the impact of all of the aforementioned Core Recommendations on the $100 \%$ Townhouse Base Case Subdivision, in order to understand their cumulative impact. 


\section{CHAPTER 4: META ANALYSIS OF CORE RECOMMENDATIONS \#1-\#17}

In this chapter, the Core Recommendations were combined in order to assess the overall impact of their implementation on the Base Case Scenario on the Return on Equity for the Developer.

\section{1 - EVERYTHING EXCEPT MIXED USE (EFFECT OF RECOMMENDATIONS \#2 - \#17)}

In Section 3.1, it was demonstrated that Core Recommendation \#1 - Mixed Use Areas had substantial impact on the ROE of the project. This recommendation alone lowered the $100 \%$ Townhouse Base Case Subdivision's ROE by $26.97 \%$. Therefore, it was decided that the net effect on ROE of Recommendations \#2-17 would be calculated. This is to understand how the other Core Recommendations would have an impact on a subdivision without incorporating a mixed use building, and therefore demonstrating how the typical model of a subdivision community could be greatly improved with smaller changes.

\section{How can this be measured?}

This pro forma analysis used the assumptions from Illustration 2 - Small Blocks, Irregular Grid and Winding Streets, and escalated the Core Recommendations accordingly to fit the new number of streets, intersections, average lots per acre, percentage of the development that is Right-of-Way, and linear metres of roads. Table 34 tallies the results:

Table 34: ROE Comparison (Everything Except Mixed Use)

\begin{tabular}{|l|l|}
\hline Base Case & ROE \\
\hline Base Case with Everything Except Mixed Use & $46.45 \%$ \\
\hline
\end{tabular}

See Appendices 15A and 15B for the full assumptions and pro forma analysis.

\section{CONCLUSION}

In conclusion, it is evident that implementing these recommendations could not only benefit people with dementia, but also benefit a majority of people in society, including some other vulnerable groups like the visually impaired. The change in ROE was large at $15.66 \%$. While this may be a large difference, it is worth noting that the ROE is still well above what is considered an 
appropriate rate of return (15-20\%) by the literature (Peiser \& Hamilton, 2012, p.103) and key informant interviews. It is also worth noting that this calculation includes the very best of the possible design changes that could be made, at their highest prices, in an attempt to demonstrate the maximum cost to a developer for implementing these changes. These recommendations not only help those with dementia to navigate subdivisions better, but it helps other persons as well. These recommendations are an attempt to build more spaces that contain meaning, and promote connectivity within a neighbourhood.

\section{2 - EVERYTHING (EFFECT OF RECOMMENDATIONS H1-Hi17)}

This section analyzes the cumulative impact of all 17 Core Recommendations, in order to understand how implementing the lesser impactful recommendations (from Section 4.2) look when combined with a mixed use building.

\section{How can this be measured?}

In addition to utilizing the pro forma from \#1 - Mixed Use Areas, this pro forma analysis used the assumptions from Illustration 2 - Small Blocks, Irregular Grid and Winding Streets, and escalated the Core Recommendations accordingly to fit the new number of streets, intersections, average lots per acre, percentage of the development that is Right-of-Way, and linear metres of roads. Table 35 tallies the results.

Table 35: ROE Comparison (Everything)

\begin{tabular}{|l|l|}
\hline & ROE \\
\hline Base Case & $46.45 \%$ \\
\hline Base Case with all Core Recommendations & $8.35 \%$ \\
\hline
\end{tabular}

See Appendices 16A and 16B for the full assumptions and pro forma analysis.

\section{CONCLUSION}

While Burton \& Mitchell (2006) encourage a variety of uses to be within $800 \mathrm{~m}$ of a person with dementia's home, the current norms for developing subdivisions in Whitby make this a difficult task. The cost of incorporating a mixed use building and the other Core Recommendations into a subdivision compared with a $100 \%$ residential subdivision has a substantial effect on the ROE of the 
project, lowering it by a total of $38.1 \%$. This speaks to the importance of the offering of incentives by the Town and/or Region. It also means that the Town could encourage such development through the Official Plan or Zoning By-law, however this might have to also incorporate some form of incentive. The Town has to make a decision to improve their future neighbourhoods in greenfield areas from their inception, and a way to do this is balancing regulation with incentives.

\section{3 - EVERYTHING (EFFECT OF RECOMMENDATIONS Hi1-Hi17) WITH IINCENTIVES}

The aggregate impact on the ROE of the 17 Core Recommendations is less than what the literature and key informant interviews deems as the typical range of return for a developer (15\%$20 \%$ ). In order to bring the $8.35 \%$ ROE within this range, a variety of easily implemented and commonly used incentives that the Town of Whitby could employ were analyzed.

\section{How can this be measured?}

In order to understand the effect of different incentives on the ROE of implementing Core Recommendations \#1 - \#17, this section tested the effects of Development Charge Waivers and Parking Requirement Reductions. These incentives are commonly used by municipalities on a siteby-site basis, and could be combined into a Community Improvement Plan (See Appendix 18 for a full explanation of this commonly used planning tool). The effects of the incentives that put the ROE in the $15 \%-20 \%$ range are summarized below.

Table 36: ROE Comparison (Everything with Incentives)

\begin{tabular}{|l|l|}
\hline Base Case & ROE \\
\hline $\begin{array}{l}\text { Base Case with all Core Recommendations + } \\
\text { Development Charge Reduction of 15\% + } \\
25 \% \text { Parking Reduction }\end{array}$ & $46.45 \%$ \\
\hline
\end{tabular}

See Appendices 17A and 17B for the full assumptions and pro forma analysis.

\section{CONCLUSION}

While Burton \& Mitchell (2006) encourage a variety of uses to be within 800m of a person's home, constructing one mixed use building within walking distance of homes is a great first step. If one combined a Development Charge Reduction of $15 \%$ with a $25 \%$ Parking Requirement Reduction, 
the project would reach an ROE of $16.86 \%$, which is well within the range of the considered acceptable rate of return for a developer (15\%-20\%). The point here is to demonstrate that residential neighbourhoods can be built so that they are actually walkable, by providing retail within a corner of the subdivision through legislative changes. If that does not work, incentives can be offered as a last resort and this analysis proves it can be done at a minimal cost to the Town of Whitby. In addition, the Excel Tool created for this MRP can aid Staff in negotiating for design features and uses with Developers, in addition to testing different incentives.

The next chapter will discuss how the implementation of these Core Recommendations can be realized through regulation and/or incentives offered by the Town of Whitby. 


\section{CHAPTER 5: RECOMMENDATIONS}

As is evident from a review of these Core Recommendations, there is no one ultimate solution that will automatically make neighbourhoods 'dementia-friendly', just like there is no magic solution to make an environment universally accessible. The theory of universal design accepts that there are a multitude of barriers present in our environments for many different groups, but it is impossible to remove them all. The goal of universal design is to break down as many barriers as possible. Even though many of the recommendations from this project are already cited as universal design principles (Personal Communication with AC, March 19, 2015 and Town of Whitby Accessibility Standards, 2005), and many relate to making a turn towards walkable communities with place-making features, they all represent what might make a community more legible, comfortable, accessible, distinctive, familiar and safe for someone with dementia. By detailing the overall costs of such improvements, hopefully municipalities can be inspired to change their policies or put more pressure on developers to include such improvements in their developments.

Whitby is already seeking to improve their downtown core areas and in the words of their Mayor Don Mitchell, "We're trying to get more people living there and make more active, supportive environments with amenities," (Wong, March 25, 2015, NRU GTA Edition Vol. 18, No. 12, p. 7). This represents a wider turn by the Town Council to create walkable neighbourhoods with amenities in Whitby, and this report has detailed a few ways to do this for new greenfield subdivisions, which according to the Growth Plan will make up to 55\% of Whitby's growth in the next few decades.

This report has demonstrated that when combined, Core Recommendations \#2-17 and Core Recommendations \#1-17 have varying effects on Return on Equity (ROE). While the assumed costs of development may vary on a site specific basis, the assumptions made for this MRP are quite 
conservative $^{8}$. The purpose of this MRP is to demonstrate that building a Dementia-Friendly

neighbourhood can be accomplished in the Town of Whitby, which has been demonstrated through the pro forma analyses.

The effect on the ROE of a project for implementing Core Recommendations 2-17, while having an effect, still leaves the project above the expected return rate of $15-20 \%$ (a range indicated by both key informants and Peiser \& Hamilton, 2012, p. 103). That being said, the effect on the ROE of the project when Core Recommendations 1-17 are implemented is substantial. It is obvious that these changes will not be implemented without regulatory change and/or some form of incentives.

Table 37: Overall ROE Comparison

\begin{tabular}{|l|l|}
\hline Base Case Subdivision & ROE \\
\hline Base Case with Recommendations \#2 - \#17 & $46.45 \%$ \\
\hline Base Case with Recommendations \#1 - \#17 & $30.79 \%$ \\
\hline $\begin{array}{l}\text { Base Case with Recommendations \#1 - \#17 } \\
\text { Plus Incentives from Section 4.3 }\end{array}$ & $8.35 \%$ \\
\hline
\end{tabular}

\subsection{KEY FINDINGS}

There are key findings from this MRP that could turn into recommendations for the Town of

Whitby (and perhaps other suburban municipalities in the GTA region with greenfield areas designated for development):

1. Mixed use development, as a portion of a Subdivision site is possible in the Town of Whitby, and achieves a $19.48 \%$ return, which is well within the desired range of $15-20 \%$.

2. Incorporating dementia-friendly urban design recommendations into a subdivision (Core Recommendations \#2-17) is possible and has a low impact on a developer's rate of return.

3. Incorporating dementia-friendly urban design recommendations into a subdivision (Core Recommendations \#2-17) as well as a mixed use site (Core Recommendation \#1) is possible with the help of a limited incentives. For example, with a $25 \%$ parking reduction and $15 \%$ reduction in Development Charges, the development would still have an ROE of $16.86 \%$, well within the $15-20 \%$ range that is deemed suitable by both literature and key informant interviews.

\footnotetext{
8 The assumptions are also conservative as mid-rise buildings have the potential to be built using wood frame construction with the advent of the new Ontario Building Code. This is estimated to decrease costs by $\$ 20-\$ 25$ per square foot (Bedford for BILD, 2013, p.10). In addition, larger sites (like the one used for these analyses) are less prone to fluctuations in pricing.
} 
5.2 RECOMMENDATIONS FOR THE TOWN OF WHITBY

Based on the work completed throughout Chapter 3: Investigation and Chapter 4: Meta-Analysis of

Core Recommendations, there are many ways the Town of Whitby could utilize the findings from this MRP, including both short term as well as long term recommendations. As Przydatek (2012) found, while planners may be willing to consider dementia-friendly design, it is not something that is on their radar (p. 105, 108). In order for the average professional planner to consider dementiafriendly design and planning, it has to be written into the legislation they use every day - and these recommendations demonstrate how the Town of Whitby could accomplish this.

\section{Short Term}

This recommendation could be implemented within a short time frame.

\section{RECOMMENDATION \#1}

That the Town of Whitby (and other suburban municipalities like it with developable greenfield areas) use these cost recommendations (\#1-17) as tool for negotiating Plan of Subdivision and Site Plan designs with developers. This could be used to demonstrate that these costs pose a low impact on rate of return for developers, and could help them in negotiating for better communities, with more walkable areas. The Excel Tool created for this MRP could also be manipulated by Staff to reflect site specific characteristics to be used in helping Staff negotiate with Developers.

\section{Long Term}

These recommendations are comprehensive in scope and will take a greater period of time to accomplish. The 'dementia-friendly' recommendations could be incorporated into the Town of Whitby's planning policies, in a way that seeks to make the Town better for all - a potential theme could be 'Creating Neighbourhoods for Life.' The planning policies of the Town would be altered in the following manner, which follows the recommendations made by the Meridian Planning Consultants Study (2011) on Urban Design in Whitby: 


\section{RECOMMENDATION \#2}

That the Town of Whitby incorporate the ideals of building a truly inclusive city throughout the life course is by inserting it as a Guiding Principle within the Town's Official Plan. A suggestion would be to add the following to Section 2.1 -"The Municipality's Guiding Principles for Development in the Official Plan are:"

To encourage urban design and land use strategies that are sensitive to the needs of those with physical and/or cognitive disabilities as well as all persons throughout the life course.

If Whitby did this, they would become the only municipality in Canada to recognize the specialized needs of those with a cognitive disability within a statutory planning policy ${ }^{9}$. Whitby already has the award winning and innovative Abilities Centre. The Town could build on this and expand its role as an incubator and example for Ontario in testing urban design features and land use strategies that best support these marginalized groups.

\section{RECOMMENDATION \#3}

That the Town of Whitby actualize the 'dementia-friendly' design recommendations within the Official Plan by creating directive policy on how to develop greenfield areas. The Region of Durham's definition of 'Living Area' includes accessory uses that fit within the character of a neighbourhood, such as retail uses, doctor's offices etc. and the definition of Residential Areas within the current Official Plan also allows for these ancillary uses. However, the allowance of such uses is not an effective way to encourage developers to help build communities where amenities are a short walk away (as is evidenced by current development patterns and the results from the pro forma analysis in Section 3.1). In order to accomplish this, the Town could designate corners of arterial roads (in the lands within the urban boundary that are at present, agricultural fields) as mixed use ${ }^{10}$. Regulation would force developers to build mixed use amenities within their subdivisions, as well as directly contributing to making the neighbourhood walkable. There would

\footnotetext{
9 To the best of the author's knowledge, the only country which recognizes the needs of people with cognitive impairments in land use planning and urban design is Sweden.

10 An example of one such intersection would be Conlin Road and Anderson Street.
} 
also be little planning justification for a developer to fight such a designation as it has been proven that their development is still appropriately profitable, as well as achieving walkability for the Town. In addition, by outlining this within the Official Plan (as well as being supported by a Guiding Principle), the Town of Whitby is less vulnerable to site-specific amendments.

\section{RECOMMENDATION \#4}

That the Town of Whitby should reflect the designations and directions from the Official Plan into the Zoning By-law, continuing to encourage mixed use on corners within the urban boundary. The Town could decide to implement the Core Recommendations \#2-17 into the Zoning By-law. The other option is to establish them as Urban Design Guidelines that are either incorporated into the Zoning By-law or Official Plan (which would make them statutory and require an OP of ZBL amendment to alter) or have them as a standalone document (non-statutory).

\section{RECOMMENDATION \#5}

That the Town of Whitby consider the use of incentives to encourage 'dementia-friendly' urban design and land use strategies. Through the analysis completed in this MRP, it has been demonstrated that incorporating a small mixed use building into a Plan of Subdivision as well as incorporating the Core Recommendations \#2-\#17 might require some financial assistance from the municipality, through parking requirement reductions, for example. Most notably a combination of a Development Charge Reduction of $15 \%$, and a Parking Reduction of $25 \%$ makes implementing Core Recommendations \#1-17 worthwhile, to a Return on Equity of $16.26 \%$, which is within the acceptable range. That being said, a municipality does not want to provide incentives for something that may happen anyway as a result of market forces. However, current development patterns and the pro forma analysis suggests that if Whitby is serious about building walkable communities, they may have to offer incentives for a period of time ${ }^{11}$.

\footnotetext{
11 This could be accomplished through a temporary Community Improvement Plan, which provides the legal ability to offer a wide range of incentives in one package. The CIP also allows a municipality to reserve the right to refuse incentives to a particular development, and ensure that the desired development is built by not releasing the incentive until there is proof
} 


\section{NOTA BENE}

Obviously, the implementation of the above recommendations and subsequent planning policies

would require extensive consultation with the public. Whitby could use this process as a way to

hear community feedback about the changes proposed and learn what public suggests themselves.

\subsection{SUMMARY OF CORE RECOMMENDATIONS, EFFECT ON ROE AND SUGGESTIONS FOR IMPLEMENTATION}

This section summarizes how each recommendation may be incorporated into the Town of

Whitby's Planning Policies, which is to provide a more detailed perspective to be read in

conjunction with Section 4.2 .

\begin{tabular}{|c|c|c|c|}
\hline & $\begin{array}{l}\text { Currently Mentioned within Whitby } \\
\text { Planning Documents? }\end{array}$ & ROE & $\begin{array}{c}\text { What could be changed to incorporate this } \\
\text { Core Recommendation? }\end{array}$ \\
\hline Base Case & $\mathrm{n} / \mathrm{a}$ & $46.45 \%$ & $\mathrm{n} / \mathrm{a}$ \\
\hline $\begin{array}{l}\# 1 \\
\text { Mixed use }\end{array}$ & $\begin{array}{l}\text { Mentioned briefly in the Whitby } \\
\text { Official Plan and Zoning By-law as a } \\
\text { specific type of use. The Region of } \\
\text { Durham's Official Plan however, allows } \\
\text { for Mixed Use buildings within their } \\
\text { designated "Living Areas." }\end{array}$ & $18.92 \%$ & See Section 4.2 \\
\hline $\begin{array}{l}\# 2 \\
\text { Wide, } \\
\text { Smooth } \\
\text { Footways }\end{array}$ & $\begin{array}{l}\text { The standards for footpaths are } \\
\text { outlined in the Engineering Standards } \\
\text { for the Town, but lack the specific } \\
\text { changes proposed by this research. }\end{array}$ & $46.41 \%$ & $\begin{array}{l}\text { Update the Engineering Standards to reflect } \\
\text { the Core Recommendation. }\end{array}$ \\
\hline $\begin{array}{l}\text { \#3 Frequent } \\
\text { Road } \\
\text { Crossings }\end{array}$ & $\begin{array}{l}\text { The standards for safety measures at } \\
\text { road crossings are outlined in the } \\
\text { Engineering Standards for the Town, } \\
\text { but lack the specific changes proposed } \\
\text { by this research. }\end{array}$ & $46.2 \%$ & $\begin{array}{l}\text { Update the Engineering Standards to reflect } \\
\text { the Core Recommendation. }\end{array}$ \\
\hline \begin{tabular}{|l|}
$\# 4$ \\
Clear Signs
\end{tabular} & $\begin{array}{l}\text { Is outlined in the Town of Whitby's } \\
\text { Sign By-law, but lacks the specific } \\
\text { changes proposed by this research. }\end{array}$ & $46.38 \%$ & $\begin{array}{l}\text { Update the Town's Sign By-law to reflect the } \\
\text { Core Recommendation. }\end{array}$ \\
\hline $\begin{array}{l}\# 5 \\
\text { Frequent } \\
\text { Seating }\end{array}$ & $\begin{array}{l}\text { Is encouraged by the Town of Whitby's } \\
\text { Landscape Plan Design Guidelines for } \\
\text { Site Plan and Plan of Subdivision, } \\
\text { however street furniture in general } \\
\text { seems to not be encouraged by Town } \\
\text { Staff (HB/D and PC1). }\end{array}$ & $46.41 \%$ & $\begin{array}{l}\text { This could be added to the Landscape } \\
\text { Design of Site Plan and Plan of Subdivision } \\
\text { Guidelines and strongly suggested by Staff } \\
\text { through the pre-consultation stage to Draft } \\
\text { Plan approval stage. It could also be added to } \\
\text { the Zoning By-law, when the appropriate } \\
\text { massing of residential areas is mentioned. It } \\
\text { could also be added to the Zoning By-law, }\end{array}$ \\
\hline
\end{tabular}

of construction. These abilities, combined with the right to dissolve the program at any time, make it a useful tool that can also protect a municipality. 


\begin{tabular}{|c|c|c|c|}
\hline & & & $\begin{array}{l}\text { when the appropriate massing of residential } \\
\text { areas is mentioned. See Section 4.2. }\end{array}$ \\
\hline $\begin{array}{l}\# 6 \\
\text { Small } \\
\text { Blocks, } \\
\text { Irregular } \\
\text { Grid } \\
\end{array}$ & $\begin{array}{l}\text { A grid system is encouraged by the } \\
\text { Town's Official Plan as well as Zoning } \\
\text { By-law, however size of blocks and } \\
\text { types of intersections are not } \\
\text { mentioned. }\end{array}$ & $34.35 \%$ & $\begin{array}{l}\text { Minimum and maximum length of blocks } \\
\text { could be added to the Zoning By-law and } \\
\text { Official Plan, when the appropriate design } \\
\text { and massing of residential areas is } \\
\text { mentioned. See Section } 4.2 \text {. }\end{array}$ \\
\hline $\begin{array}{l}\# 7 \\
\text { Marked } \\
\text { Level } \\
\text { Changes }\end{array}$ & $\begin{array}{l}\text { The standards for how to transition } \\
\text { from level changes are outlined in the } \\
\text { Engineering Standards for the Town, } \\
\text { but lack the specific changes proposed } \\
\text { by this research. }\end{array}$ & $46.44 \%$ & $\begin{array}{l}\text { Update the Engineering Standards to reflect } \\
\text { the Core Recommendation. }\end{array}$ \\
\hline \begin{tabular}{|l}
$\# 8$ \\
Ground \\
Level \\
Toilets
\end{tabular} & $\begin{array}{l}\text { The standards for building an outdoor } \\
\text { toilet are not listed in any of the } \\
\text { documents examined, except for the } \\
\text { Accessibility Standards. }\end{array}$ & $44.47 \%$ & $\begin{array}{l}\text { This could be added to the Landscape } \\
\text { Design of Site Plan and Plan of Subdivision } \\
\text { Guidelines and strongly suggested by Staff } \\
\text { through the pre-consultation stage to Draft } \\
\text { Plan approval stage. It could also be added to } \\
\text { the Zoning By-law, when the appropriate } \\
\text { massing of residential areas is mentioned. } \\
\text { See Section 4.2. }\end{array}$ \\
\hline \begin{tabular}{|l|}
$\# 9$ \\
Enclosed \\
Bus shelters \\
\\
\\
\end{tabular} & $\begin{array}{l}\text { The standards for enclosed bus stops } \\
\text { are outlined in the Engineering } \\
\text { Standards for the Town, but lack the } \\
\text { specific changes proposed by this } \\
\text { research. The Town's Official Plan also } \\
\text { has sections encouraging the planning } \\
\text { of transit in major developments, } \\
\text { including buildings home that are no } \\
\text { more than } 400 \mathrm{~m} \text { from a bus stop. }\end{array}$ & $46.41 \%$ & $\begin{array}{l}\text { This could be added to the Landscape } \\
\text { Design of Site Plan and Plan of Subdivision } \\
\text { Guidelines and strongly suggested by Staff } \\
\text { through the pre-consultation stage to Draft } \\
\text { Plan approval stage. It could also be added to } \\
\text { the Zoning By-law, when the appropriate } \\
\text { massing of residential areas is mentioned. } \\
\text { See Section } 4.2 \text {. }\end{array}$ \\
\hline \begin{tabular}{|l|}
$\# 10$ \\
Varied \\
Urban Form \\
\\
\\
\\
\\
\end{tabular} & $\begin{array}{l}\text { Varied Urban Form is not mentioned } \\
\text { in any of the documents. In fact, as } \\
\text { HB/D, PC1 and PC2 indicated, Town } \\
\text { Staff prefer subdivisions to "avoid a } \\
\text { scattered look" meaning that the } \\
\text { development will be one architectural } \\
\text { design with about a half dozen } \\
\text { variations on the model. This is why } \\
\text { the majority of subdivisions has such a } \\
\text { monolithic look and is confusing even } \\
\text { for the able minded. }\end{array}$ & $46.38 \%$ & $\begin{array}{l}\text { This could be added to the Landscape } \\
\text { Design of Site Plan and Plan of Subdivision } \\
\text { Guidelines and strongly suggested by Staff } \\
\text { through the pre-consultation stage to Draft } \\
\text { Plan approval stage. It could also be added to } \\
\text { the Zoning By-law, when the appropriate } \\
\text { massing of residential areas is mentioned. } \\
\text { See Section } 4.2 \text {. }\end{array}$ \\
\hline $\begin{array}{l}\# 11 \\
\text { Buffer } \\
\text { Zones }\end{array}$ & $\begin{array}{l}\text { The standards for buffer zones are } \\
\text { outlined in the Engineering Standards, } \\
\text { and match the recommendations } \\
\text { made by this research. }\end{array}$ & $46.45 \%$ & $\begin{array}{l}\text { Maintain the Engineering Standards to } \\
\text { reflect the Core Recommendation. }\end{array}$ \\
\hline
\end{tabular}




\begin{tabular}{|c|c|c|c|}
\hline $\begin{array}{l}\# 12 \\
\text { Landmarks }\end{array}$ & $\begin{array}{l}\text { Landmarks are quasi encouraged by } \\
\text { the Town of Whitby's Design } \\
\text { Guidelines, however street furniture in } \\
\text { general seems to not be encouraged by } \\
\text { Town Staff (HB/D and PC1). }\end{array}$ & $46.35 \%$ & $\begin{array}{l}\text { This could be added to the Landscape } \\
\text { Design of Site Plan and Plan of Subdivision } \\
\text { Guidelines and strongly suggested by Staff } \\
\text { through the pre-consultation stage to Draft } \\
\text { Plan approval stage. It could also be added to } \\
\text { the Zoning By-law, when the appropriate } \\
\text { massing of residential areas is mentioned. It } \\
\text { could also be added to the Zoning By-law, } \\
\text { when the appropriate massing of residential } \\
\text { areas is mentioned. See Section } 4.2 \text {. }\end{array}$ \\
\hline $\begin{array}{l}\# 13 \\
\text { Hierarchy }\end{array}$ & This Core Recommendation & was cov & vered by \#10 - Varied Urban Form. \\
\hline $\begin{array}{l}\# 14 \\
\text { Distinctive } \\
\text { Features at } \\
\text { Junctions }\end{array}$ & $\begin{array}{l}\text { Distinctive features at junctions are } \\
\text { quasi encouraged by the Town of } \\
\text { Whitby's Design Guidelines, however } \\
\text { street furniture in general seems to not } \\
\text { be encouraged by Town Staff (HB/D } \\
\text { and PC1) }\end{array}$ & $46.34 \%$ & $\begin{array}{l}\text { This could be added to the Landscape } \\
\text { Design of Site Plan and Plan of Subdivision } \\
\text { Guidelines and strongly suggested by Staff } \\
\text { through the pre-consultation stage to Draft } \\
\text { Plan approval stage. It could also be added to } \\
\text { the Zoning By-law, when the appropriate } \\
\text { massing of residential areas is mentioned. It } \\
\text { could also be added to the Zoning By-law, } \\
\text { when the appropriate massing of residential } \\
\text { areas is mentioned. See Section } 4.2 \text {. }\end{array}$ \\
\hline \begin{tabular}{|l}
$\# 15$ \\
Buildings \\
with \\
Obvious \\
Entrances \\
$\# 16$ \\
Buildings \\
that Reflect \\
Use
\end{tabular} & \multicolumn{3}{|c|}{ These Core Recommendations were not calculated. } \\
\hline $\begin{array}{l}\# 17 \\
\text { Gently } \\
\text { Winding } \\
\text { streets }\end{array}$ & \multicolumn{3}{|c|}{ This Core Recommendation became part of \#6 - Small Blocks and Irregular Grid. } \\
\hline
\end{tabular}

\subsection{CONCLUSION}

In conclusion, there are a number of ways that the Town of Whitby could become a leader in

establishing policies that encourage walkability and make their municipality welcoming for people with dementia, as well as for others who experience cognitive decline or even a form of cognitive impairment. While there has been limited research on the topic of 'dementia-friendly' urban design and land use strategies, the Core Recommendations outlined by the MRP have been found to be 
both sound within planning literature as well as within the dementia design related literature available. The Core Recommendations have also been found to have minimal effects on the Return on Equity of a project for a developer (and when they did, this paper outlined a strategy for mitigating these impacts), demonstrating that establishing these recommendations as policy will not deter people from investing in Whitby. Many of the recommendations have to do with universal design, a return to place-making as well as enabling communities to be walkable - all positive aspects to be encouraged. This MRP can also serve to educate the planning profession about a topic and group of people with needs that planners currently ignore - those with dementia, and those with a cognitive impairment. Planners will consider the specialized needs of these types of groups if they are written into the legislation and frameworks they use every day. There is a huge opportunity for the Town of Whitby to be the first municipality in Canada to recognize the needs of those with a cognitive impairment within their planning legislation. The Town of Whitby is currently deciding the strategy to govern how the $55 \%$ of their projected growth in greenfield areas will be developed in the coming decades. They have the chance to encourage development and design that is inclusive, and plans for people of all abilities, throughout their life course. This is the chance for Whitby to be the pioneer.

\subsection{AREAS FOR FUTURE RESEARCH}

As this is such an under-researched topic, areas for future research in the local context of Whitby could include:

- Researching the effect of subdivision design on persons with dementia who currently reside in the Town of Whitby, using methods similar to that of Burton \& Mitchell (2006). This could include accompanied walks throughout the neighbourhood and the development of more localized knowledge and awareness of the disease; and

- Utilizing similar methods employed in this MRP to examine how to implement the 17 Core Recommendations into an existing neighbourhood or infill site, particularly in the Downtown of Whitby, where the Mayor wishes to see an improvement in its design and development. 


\begin{tabular}{|c|c|c|c|c|}
\hline Key Document & $\begin{array}{l}\text { Year } \\
\text { Published }\end{array}$ & $\begin{array}{l}\text { Type of } \\
\text { Document }\end{array}$ & Sample & Is it to be used to evaluate the 17 Recommendations? If no, why not? \\
\hline $\begin{array}{l}\text { Blackman, T., Mitchell, L., Burton, E., Jenks, M., Parsons, M., Raman, S. \& Williams, K. (2003). The } \\
\text { accessibility of public spaces for people with dementia: a new priority for the 'open city'. } \\
\text { Disability and Society, } 18,357-71 \text {. }\end{array}$ & 2003 & $\begin{array}{l}\text { Scholarly } \\
\text { Article }\end{array}$ & $\begin{array}{l}\text { Collates findings from } \\
\text { earlier studies }\end{array}$ & Yes \\
\hline $\begin{array}{l}\text { Mitchell, L., Burton, E., Raman, S., Blackman, T., Jenks, M. \& Williams, K. (2003). Making the } \\
\text { outside world dementia-friendly: design issues and considerations. Environ Planning B: } \\
\text { Planning Design, 30, 605-32. }\end{array}$ & 2003 & $\begin{array}{l}\text { Scholarly } \\
\text { Article }\end{array}$ & Literature Review & Yes \\
\hline $\begin{array}{l}\text { Mitchell, L., \& Burton, E., \& Raman, S. (2004). Dementia-friendly cities: designing intelligible } \\
\text { neighbourhoods for life. Journal of Urban Design 9, 89-101. }\end{array}$ & 2004 & $\begin{array}{l}\text { Scholarly } \\
\text { Article }\end{array}$ & $\begin{array}{l}20 \text { people with dementia } \\
\text { and } 25 \text { people without } \\
\text { dementia }\end{array}$ & $\begin{array}{l}\text { No, since this is the same experiment that was used to create the } 17 \text { core recommendations that } \\
\text { these articles are used to review. }\end{array}$ \\
\hline $\begin{array}{l}\text { Mitchell, L., \& Burton, E. (2006). Neighbourhoods for life: Designing dementia-friendly outdoor } \\
\text { environments. Quality in Ageing: Policy, practice and research 7, 26-33. }\end{array}$ & 2006 & $\begin{array}{l}\text { Scholarly } \\
\text { Article }\end{array}$ & $\begin{array}{l}20 \text { people with dementia } \\
\text { and } 25 \text { people without } \\
\text { dementia }\end{array}$ & $\begin{array}{l}\text { No, since this is the same experiment that was used to create the } 17 \text { core recommendations that } \\
\text { these articles are used to review. }\end{array}$ \\
\hline $\begin{array}{l}\text { Sheehan, B., Burton, E., \& Mitchell, E. (2006). Outdoor wayfinding in dementia. Dementia, 5(2), 271- } \\
81\end{array}$ & 2006 & $\begin{array}{l}\text { Scholarly } \\
\text { Article }\end{array}$ & $\begin{array}{l}13 \text { people with dementia, } \\
10 \text { control }\end{array}$ & Yes \\
\hline $\begin{array}{l}\text { Blackstock, K.L., Innes, A., Cox, B., Smith, A., \& Mason, A. (2006). Living with dementia in rural and } \\
\text { remote Scotland: Diverse experiences of people with dementia and their carers. Rural Studies 22, } \\
161-76 .\end{array}$ & 2006 & $\begin{array}{l}\text { Scholarly } \\
\text { Article }\end{array}$ & $\begin{array}{l}15 \text { people with dementia, } \\
30 \text { carers }\end{array}$ & $\begin{array}{l}\text { No, since this article is primarily about service delivery, and it does not elucidate anything about } \\
\text { the relationship between the built environment and people with dementia. }\end{array}$ \\
\hline $\begin{array}{l}\text { Mitchell, L. (2007). Neighbourhoods for life: the outdoor environment. Journal of Dementia Care, } \\
\text { 15,36-37. }\end{array}$ & 2007 & $\begin{array}{l}\text { Scholarly } \\
\text { Article }\end{array}$ & $\begin{array}{l}20 \text { people with dementia } \\
\text { and } 25 \text { people without } \\
\text { dementia }\end{array}$ & $\begin{array}{l}\text { No, since this is the same experiment that was used to create the } 17 \text { core recommendations that } \\
\text { these articles are used to review. }\end{array}$ \\
\hline $\begin{array}{l}\text { Blackman, T., Van Shaik, P., \& Martyr, A. (2007). Outdoor Environments for people with dementia: } \\
\text { an exploratory study using virtual reality. Ageing and Society 6, 811-825. }\end{array}$ & 2007 & $\begin{array}{l}\text { Scholarly } \\
\text { Article }\end{array}$ & $\begin{array}{l}38 \text { participants with } \\
\text { mild to moderate } \\
\text { dementia. }\end{array}$ & Yes \\
\hline $\begin{array}{l}\text { Van Schaik, P., Martyr, A., Blackman, T., \& Robinson, J. (2008). Involving persons with dementia in } \\
\text { the evaluation of outdoor environments. CyberPsychology \& Behavior, } 11 \text { (4), 415-24. }\end{array}$ & 2008 & $\begin{array}{l}\text { Scholarly } \\
\text { Article }\end{array}$ & $\begin{array}{l}38 \text { participants with } \\
\text { mild to moderate } \\
\text { dementia. }\end{array}$ & Yes \\
\hline $\begin{array}{l}\text { Duggan, S., Blackman, T., Martyr, A., \& Van Schaik, P. (2008). The impact of early dementia on } \\
\text { outdoor life: a 'shrinking world'? Dementia } 7 \text { (2), , 191-204. }\end{array}$ & 2008 & $\begin{array}{l}\text { Scholarly } \\
\text { Article }\end{array}$ & $\begin{array}{l}22 \text { people with mild to } \\
\text { moderate plus carers }\end{array}$ & Yes \\
\hline $\begin{array}{l}\text { Yevchak, A.M., Loeb, S.J., \& Fick, D.M. (2008). Promoting cognitive health and vitality: a review of } \\
\text { clinical implications. Geriatric Nurse, } 29,302-10 \text {. }\end{array}$ & 2008 & $\begin{array}{l}\text { Scholarly } \\
\text { Article }\end{array}$ & Literature review & $\begin{array}{l}\text { No. This article is a summary of clinical studies to show geriatric nurses the kinds of healthy } \\
\text { lifestyles they should be promoting. The summary of findings say that in order to promote } \\
\text { cognitive vitality, people must try to lower their risks for chronic disease, have a balanced } \\
\text { nutritional diet, get more physical activity, participate in social interactions and exercise their } \\
\text { brain through stimulating activities. While the studies used in this review were very } \\
\text { informative, none of them looking at the impact of the built environment on people with } \\
\text { dementia. }\end{array}$ \\
\hline $\begin{array}{l}\text { Mitchell, L., \& Burton, E. (2010). Designing dementia-friendly neighbourhoods: helping } \\
\text { people with dementia to get out and about. Journal of Integrated Care, 18, 12-19. }\end{array}$ & 2010 & $\begin{array}{l}\text { Scholarly } \\
\text { Article }\end{array}$ & $\begin{array}{l}20 \text { people with dementia } \\
\text { and } 25 \text { people without } \\
\text { dementia }\end{array}$ & $\begin{array}{l}\text { No, since this is the same experiment that was used to create the } 17 \text { core recommendations that } \\
\text { these articles are used to review. }\end{array}$ \\
\hline $\begin{array}{l}\text { Brittain, K.R., Corner, L., Robinson, L., \& Bond, J. (2010). Ageing in place and technologies of place: } \\
\text { the lived experience of people with dementia in changing social, physical and technological } \\
\text { environments. Sociology of Health and Illness, } 32 \text { (2), 272-287. }\end{array}$ & 2010 & $\begin{array}{l}\text { Scholarly } \\
\text { Article }\end{array}$ & $\begin{array}{l}16 \text { people with dementia } \\
+ \text { carers }\end{array}$ & Yes \\
\hline $\begin{array}{l}\text { Brorsson, A., Ohman, A., Lundberg, S., \& Nygard L. (2011). Accessibility in public space as } \\
\text { perceived by people with Alzheimer's disease. Dementia, 10,587-602 }\end{array}$ & 2011 & $\begin{array}{l}\text { Scholarly } \\
\text { Article }\end{array}$ & $\begin{array}{l}7 \text { informants with } \\
\text { dementia }\end{array}$ & Yes \\
\hline $\begin{array}{l}\text { Blackman, T. (2006). Placing Health: Neighbourhood Renewal, Health Improvement and } \\
\text { Complexity. Bristol: The Policy Press. }\end{array}$ & 2006 & Book & N/A & No, as Keady et al. (2012) note that the scholarly articles make up the bulk of the key messages. \\
\hline
\end{tabular}




\begin{tabular}{|c|c|c|c|c|}
\hline Burton, E. \& Mitchell, L. (2006). Inclusive Urban Design: Streets for Life. Oxford: Elsevier Ltd. & 2006 & Book & $\begin{array}{l}20 \text { people with dementia } \\
\text { and } 25 \text { people without } \\
\text { dementia }\end{array}$ & $\begin{array}{l}\text { No, since this is the same experiment that was used to create the } 17 \text { core recommendations that } \\
\text { these articles are used to review. }\end{array}$ \\
\hline $\begin{array}{l}\text { Goodchild, C., \& Rippon, S. (2011). Dementia and the Big Society: Report from Think Tank 16th. } \\
\text { London: Department of Health. Retrieved from: } \\
\text { http://thehalcyonproject.co.uk/wp-content/uploads/2011/03/Report-Dementia-and-the-Big- } \\
\text { Society-Think-Tank-16-Feb-2011-final.pdf }\end{array}$ & 2011 & Report & $\mathrm{n} / \mathrm{a}$ & $\begin{array}{l}\text { No, since this report is based in the United Kingdom, highlighting their national policy. Instead, I } \\
\text { have included the most current Canadian report on dementia and the environment outside of } \\
\text { institutions. (See Table 2) }\end{array}$ \\
\hline $\begin{array}{l}\text { Innovations in Dementia. Dementia Capable Communities: the views of people with dementia } \\
\text { and their supporters. Innovations in Dementia. Retrieved from: } \\
\text { http://www.innovationsindementia.org.uk/DementiaCapableCommunities_fullreportFeb2011.pdf }\end{array}$ & 2011 & Report & $\mathrm{n} / \mathrm{a}$ & $\begin{array}{l}\text { No, since this report is based in the United Kingdom, highlighting their national policy. Instead, I } \\
\text { have included the most current Canadian report on dementia and the environment outside of } \\
\text { institutions. (See Table 2) }\end{array}$ \\
\hline
\end{tabular}

TABLE 2 - Summary of Other Key Dementia Literature Used to Evaluate the 17 Core Recommendations

\begin{tabular}{|c|c|c|c|c|c|}
\hline Key Document & $\begin{array}{c}\text { Year } \\
\text { Published }\end{array}$ & $\begin{array}{l}\text { Type of } \\
\text { Document }\end{array}$ & Sample & Aim & $\begin{array}{l}\text { Is it to be used to evaluate the } 17 \\
\text { Recommendations? Why? }\end{array}$ \\
\hline $\begin{array}{l}\text { Shoval, N., Wahl, H., Auslander, G., \& Isaacson, M. (2011). Use of the global } \\
\text { positioning system to measure the out-of-home mobility of older adults with } \\
\text { differing cognitive functioning. Ageing and Society (31), 849-869. }\end{array}$ & 2011 & $\begin{array}{l}\text { Scholarly } \\
\text { Article }\end{array}$ & $\begin{array}{l}41 \text { mildly demented, } \\
\text { mildly cognitively } \\
\text { impaired and } \\
\text { healthy individuals. }\end{array}$ & $\begin{array}{l}\text { This study saw the participants wear GPS trackers } \\
\text { for } 28 \text { consecutive days in order to understand how } \\
\text { far and at what time people went outside their } \\
\text { places of residence. They were then able to } \\
\text { determine average distance travelled based on the } \\
\text { three groups of people - healthy persons, those with } \\
\text { mild cognitive impairment and those with mild } \\
\text { dementia. }\end{array}$ & $\begin{array}{l}\text { This article was likely missed by Keady et al. as it does } \\
\text { not focus on the experiences of those with dementia in } \\
\text { space, rather studies their macro movements in space. } \\
\text { This study is integral to this MRP as it proves primarily } \\
\text { that the realm of people with mild dementia is } \\
\text { significantly smaller than their healthy counterparts. } \\
\text { This provides direct reasoning for creating walkable } \\
\text { communities. }\end{array}$ \\
\hline $\begin{array}{l}\text { Brorsson, A., Ohman, A., Cutchin, M., \& Nygard, L. (2013). "Managing critical } \\
\text { incidents in grocery shopping by community-living people with Alzheimer's } \\
\text { disease." Scandinavian Journal and Occupational Therapy, (2), 292-301. }\end{array}$ & 2013 & $\begin{array}{l}\text { Scholarly } \\
\text { Article }\end{array}$ & $\begin{array}{l}20 \text { participants with } \\
\text { dementia }\end{array}$ & $\begin{array}{l}\text { This study following informants from making a list } \\
\text { of groceries to travelling to the store and back again } \\
\text { while observing their actions. }\end{array}$ & $\begin{array}{l}\text { This article was published after Keady et al. published } \\
\text { their comprehensive list. Brorsson et al. had one of their } \\
\text { articles named in the Keady et al. (2012) article, and this } \\
\text { article builds on the same method, in a different } \\
\text { situation. }\end{array}$ \\
\hline $\begin{array}{l}\text { Brorsson, A., Ohman, A., Lundberg, S. \& Nygard, L. (2014). "Being a pedestrian } \\
\text { with dementia: A qualitative study using photo documentation and focus group } \\
\text { interviews." Dementia O(O), 1-17. }\end{array}$ & 2014 & $\begin{array}{l}\text { Scholarly } \\
\text { Article }\end{array}$ & 6 informants & $\begin{array}{l}\text { This study showed a focus group videos of people } \\
\text { crossing at zebra crossings to understand their } \\
\text { perceptions about the situation. }\end{array}$ & $\begin{array}{l}\text { This article was published after Keady et al. published } \\
\text { their comprehensive list. Brorsson et al. had one of their } \\
\text { articles named in the Keady et al. (2012) article, and this } \\
\text { article builds on the same method, in a different } \\
\text { situation }\end{array}$ \\
\hline $\begin{array}{l}\text { Canadian Mortgage and Housing Corporation (CMHC). (2014). Housing Options } \\
\text { for People Living with Dementia. Retrieved from: https://www03.cmhc- } \\
\text { schl.gc.ca/catalog/productDetail.cfm?cat=17\&itm=20\&lang=en\&fr=1428877235213 }\end{array}$ & 2014 & $\begin{array}{l}\text { Government } \\
\text { Report }\end{array}$ & n/a & $\begin{array}{l}\text { To provide recommendations on the design of } \\
\text { homes for persons with dementia, from making } \\
\text { modifications to an original home to how to design } \\
\text { residential care facilities, such as nursing homes or } \\
\text { retirement homes. }\end{array}$ & $\begin{array}{l}\text { To date, Canada has "no nationally mandated dementia } \\
\text { plan," (Alzheimer's Society of Canada, 2015).' This } \\
\text { Canadian Mortgage and Housing Corporation (CMHC) } \\
\text { document is the only Canadian government perspective } \\
\text { on issues linking the built environment and dementia. It } \\
\text { is important that this project be context specific and this } \\
\text { document provides what the national-level guidance is. }{ }^{2}\end{array}$ \\
\hline
\end{tabular}

${ }_{1}^{1}$ Alzheimer's Society of Canada. Jan. 15 15. “Why does Canada need a National Dementia Plan?” Retrieved from: http://www.alzheimer.ca/en/ab/Get-involved/Raise-your-voice/National-dementia-plan/Why-canada-needs-national-dementia-plan

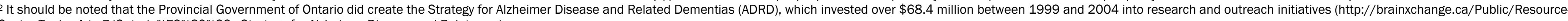
Centre-Topics-A-to-Z/Ontario\%E2\%80\%99s-Strategy-for-Alzheimer-Disease-and-Relat.aspx). 


\section{ILLUSTRATION 1: BASE CASE SCENARIO}

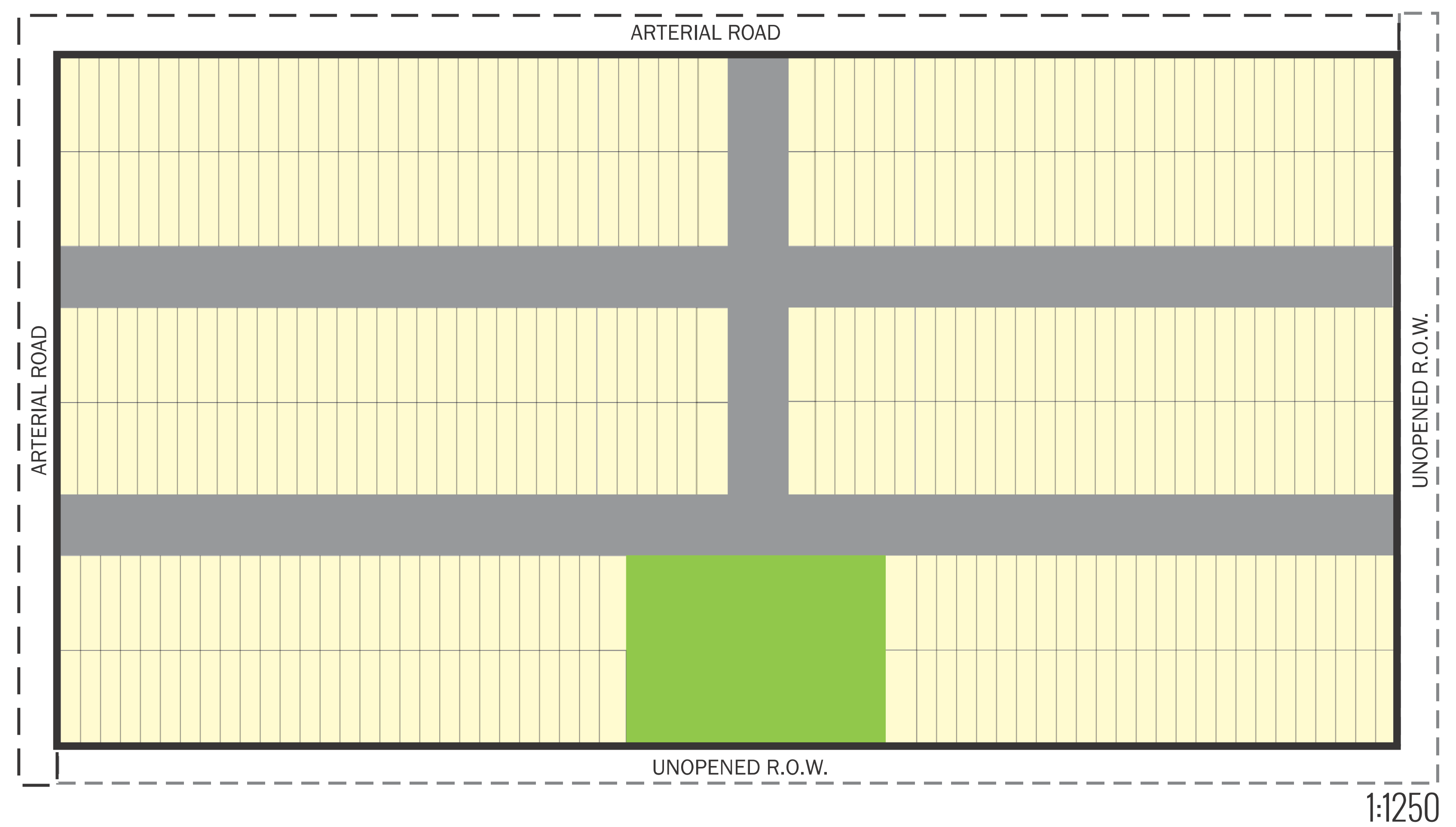

Acres of Roads: 4.01 acres (20.1\% R.O.W.)

Internal Intersections: 2

External Intersections: 3 


\section{ILLUSTRATION 2: SMALL BLOCKS, IRREGULAR GRID AND WINDING STREETS}

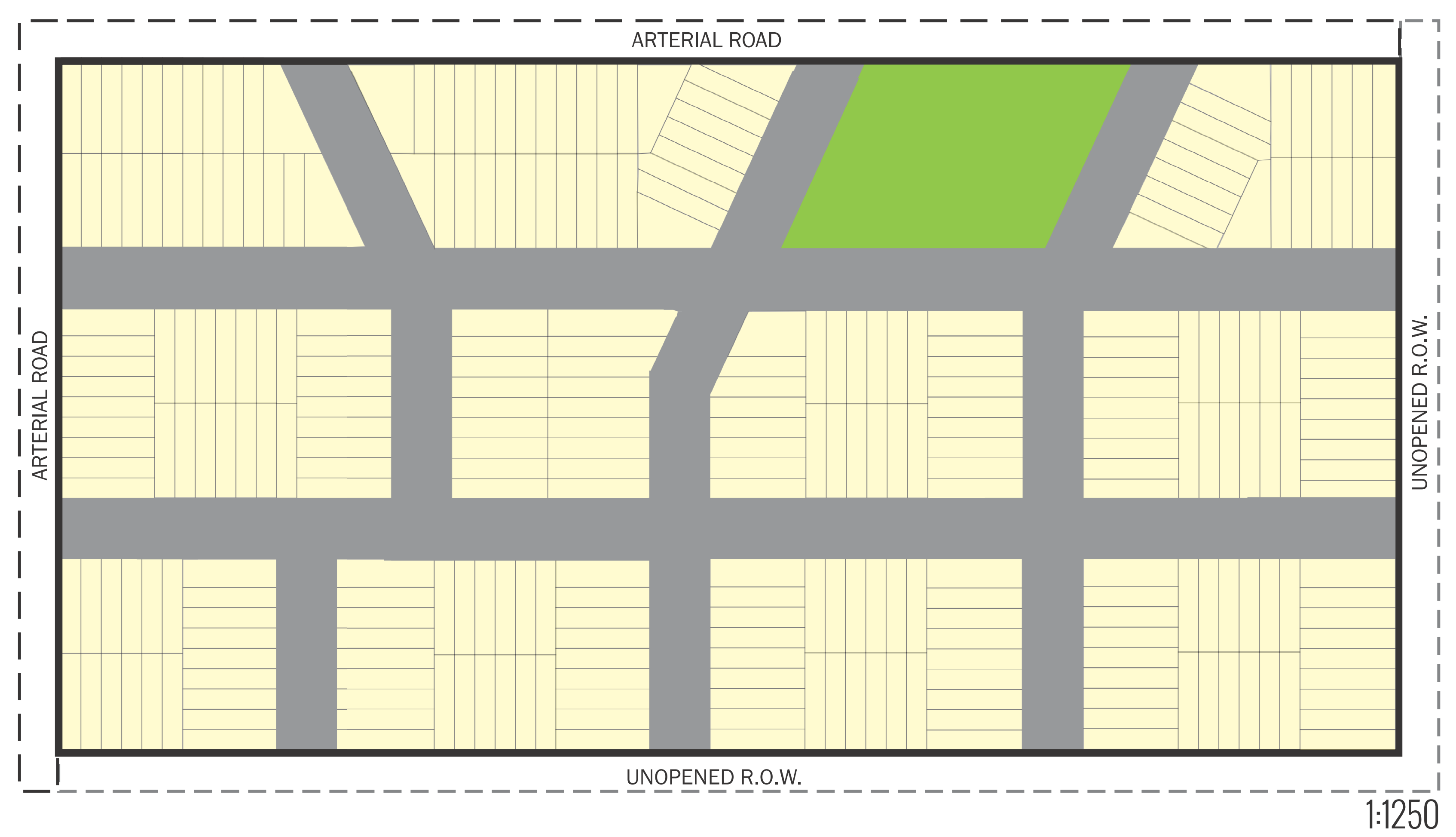

Acres of Roads: 5.91 acres (29.55\% R.O.W.)

Internal Intersections: 7

External Intersections: 5 


\section{APPENDIX 1A: BASE CASE PRO FORMA ASSUMPTIONS}

Described below are the assumptions used for this report, primarily seeking answers from professionals with Whitby-specific or accessibility-specific experience, and supplementing this with information from two widely industry used costing reports.

Key Informants

- Personal communication with Home Builder/Developer (HB/D) with over 20 years experience building homes in Whitby as President of his company (March 12, 2015).

- Personal communication with Planning Consultant \#1 (PC1), a Registered Professional Planner (RPP) with over 30 years working in Durham Region and the GTA (March 5, 2015).

- Personal communication with Planning Consultant \#2 (PC2), a Registered Professional Planner (RPP) with over 40 years working in the home building industry and as a planning consultant in the GTA (March 17, 2015).

- Personal communication with one of Ontario's leading Accessibility Consultants (AC), who is also a Registered Professional Planner (RPP) and who has a decade of experience working in Southern Ontario (March 19, 2015).

\section{Reports}

- "Altus Cost Guide", 2015

- "Costs for Pedestrian and Bicyclist Infrastructure Improvements: A Resource for Researchers, Engineers, Planners and the General Public" (Bushell, Poole, Zegeer, Roderiguez, 2013). This was a report by the University of North Carolina Highway Safety Research Centre for the Federal Highway Administration in the United States. It is a widely cited study that examined 77 pedestrian/bicycling facilities using more than 1,700 cost estimates. This report offers a median, average, minimum and maximum price for each piece of infrastructure, and the appendices below will be using the median number, as it is the best statistical method with which to represent the data. The report offers costs in 2012 \$USD, and they have been converted to 2015 \$CAD using a financial tool in the footnote below. ${ }^{1}$ This will be henceforth referred to as the "US Report."

1 Since this report was from 2013, the price was first adjusted for inflation to 2014 USD using the online tool retrieved from: http://www.westegg.com/inflation/ Next, that number was converted to CAD using the online tool retrieved from: http://www.xe.com/currencyconverter/ 


\section{Land Costs and Assumptions}

\begin{tabular}{|l|l|l|}
\hline Line Item & Assumption & Source \\
\hline Land Cost Per Acre & $\$ 500,000$ per acre & $\begin{array}{l}\text { Personal Communication with established HB/D in } \\
\text { Whitby }\end{array}$ \\
\hline $\begin{array}{l}\text { Average Townhouse } \\
\text { Size }\end{array}$ & 1500 sqft & $\begin{array}{l}\text { Personal Communication with established HB/D in } \\
\text { Whitby. }\end{array}$ \\
\hline $\begin{array}{l}\text { Net Number of Lots per } \\
\text { Acre }\end{array}$ & 19 per acre & $\begin{array}{l}\text { Gross number of 6m x 28m lots in one acre }=24 . \\
\text { This multiplied by 0.799 (to allow for 20.1\% roads) } \\
19 \text { net lots per acre *See Illustration 1: Base Case } \\
\text { Scenario }\end{array}$ \\
\hline $\begin{array}{l}\text { Average Price of a } \\
\text { Townhouse }\end{array}$ & $\$ 400,000$ & $\begin{array}{l}\text { Personal Communication with established HB/D in } \\
\text { Whitby and review of market. }\end{array}$ \\
\hline $\begin{array}{l}\text { Right-of-way (R.O.W.) as } \\
\text { a \% of Subdivision }\end{array}$ & $20.1 \%$ & See Illustration 1: Base Case Scenario \\
\hline
\end{tabular}

\section{Hard Costs}

\begin{tabular}{|c|c|c|}
\hline Line Item & Assumption & Source \\
\hline $\begin{array}{l}\text { Road Construction } \\
\text { including asphalt and } \\
\text { ALL utilities underneath } \\
\text { (per m of } 8.5 \mathrm{~m} \text { wide } \\
\text { road) }\end{array}$ & $\begin{array}{l}\$ 2300 \text { per linear } \\
\text { metre }\end{array}$ & $\begin{array}{l}\text { Personal Communication with established HB/D in } \\
\text { Whitby. This number also falls within the range } \\
\text { listed for Road Servicing in the GTA by the Altus } \\
\text { Cost Guide, } 2015 \text {. }\end{array}$ \\
\hline $\begin{array}{l}\text { Sidewalk cost per linear } \\
\mathrm{m} \text { ( } 1.5 \mathrm{~m} \text { wide cement })\end{array}$ & $\begin{array}{l}\text { \$150 per linear } \\
\text { metre }\end{array}$ & $\begin{array}{l}\text { Personal Communication with established HB/D in } \\
\text { Whitby. This number also falls within the range } \\
\text { listed for Road Servicing in the GTA by the Altus } \\
\text { Cost Guide, } 2015 \text {. }\end{array}$ \\
\hline $\begin{array}{l}\text { Buffer Zone cost per } \\
\text { linear m ( } 8 \text {-10ft wide } \\
\text { grass and trees) }\end{array}$ & $\$ 89$ per linear metre & $\begin{array}{l}\text { Personal Communication with established HB/D in } \\
\text { Whitby. This number also falls within the range } \\
\text { listed for Road Servicing in the GTA by the Altus } \\
\text { Cost Guide, } 2015 \text {. }\end{array}$ \\
\hline $\begin{array}{l}\text { Street Lighting } \\
\text { (including Hydro } \\
\text { connections to lot line) }\end{array}$ & $\begin{array}{l}\$ 280 \text { per linear } \\
\text { metre }\end{array}$ & $\begin{array}{l}\text { Personal Communication with established HB/D in } \\
\text { Whitby. This number also falls within the range } \\
\text { listed for Road Servicing in the GTA by the Altus } \\
\text { Cost Guide, } 2015 \text {. }\end{array}$ \\
\hline $\begin{array}{l}\text { Tree Planting (on lots } \\
\text { only, about } 0.8 \text { trees per } \\
\text { lot) }\end{array}$ & $\$ 400$ per tree & $\begin{array}{l}\text { Personal Communication with established HB/D in } \\
\text { Whitby. This number also falls within the range } \\
\text { listed for Road Servicing in the GTA by the Altus } \\
\text { Cost Guide, } 2015 \text {. }\end{array}$ \\
\hline $\begin{array}{l}\text { 'Hook up' Cost per lot } \\
\text { (connecting the home to } \\
\text { the utilities under the } \\
\text { Right-of-Way) }\end{array}$ & $\$ 3,864$ & $\begin{array}{l}\text { Since the author was unable to obtain this cost } \\
\text { from Whitby sources, the price from a comparable } \\
\text { GTA municipality, Newmarket, was used. "User Fees } \\
\text { Schedule E." Town of Newmarket, 2009. Retrieved } \\
\text { from: } \\
\text { http://www.newmarket.ca/recreationplaybook/reso } \\
\text { urces/408005_engineering_services_user_fees.pdf }\end{array}$ \\
\hline
\end{tabular}




\begin{tabular}{|l|l|l|}
\hline $\begin{array}{l}\text { Housing Materials/Labor } \\
\text { Cost }\end{array}$ & $\begin{array}{l}\text { \$98 per sqft of } \\
\text { house }\end{array}$ & $\begin{array}{l}\text { Personal Communication with established HB/D in } \\
\text { Whitby. This number also falls within the range } \\
\text { listed for Townhouse Development in the GTA by } \\
\text { the Altus Cost Guide, 2015. }\end{array}$ \\
\hline
\end{tabular}

\section{Soft Costs}

\begin{tabular}{|l|l|l|}
\hline Line Item & Assumption & Source \\
\hline Soft Costs & $\begin{array}{l}\text { \$50.17 per Gross } \\
\text { Square Foot of unit }\end{array}$ & $\begin{array}{l}\text { Personal Communication with established HB/D in } \\
\text { Whitby. }\end{array}$ \\
\hline $\begin{array}{l}\text { Townhouse } \\
\text { Development Charges } \\
\text { (Town of Whitby, Region } \\
\text { of Durham and }\end{array}$ & $\$ 32,963$ per unit & "Development Charge Schedule" Town of Whitby, \\
Education) & & $\begin{array}{l}\text { 2014. Retrieved from: } \\
\text { http://whitby.ca/en/resources/csx- } \\
\text { developmentcharbesJuly12014p20140623.pdf }\end{array}$ \\
\hline
\end{tabular}

\section{Financing}

\begin{tabular}{|l|l|l|}
\hline Line Item & Assumption & Source \\
\hline Construction Loan Cost & $\begin{array}{l}\text { 10\% of the combined } \\
\text { land, hard and soft } \\
\text { costs }\end{array}$ & $\begin{array}{l}\text { An assumption based on information from PC2, and } \\
\text { is representative of a blend of two loans, which is } \\
\text { common practice among developers in the GTA. }\end{array}$ \\
\hline Contingency Fund & $\begin{array}{l}5 \% \text { of the hard and } \\
\text { soft costs }\end{array}$ & $\begin{array}{l}\text { Personal Communication with established HB/D in } \\
\text { Whitby. }\end{array}$ \\
\hline Equity & $25 \%$ & $\begin{array}{l}\text { Personal Communication with established HB/D in } \\
\text { Whitby. }\end{array}$ \\
\hline Taxes & $\begin{array}{l}5 \% \text { for GST and } 8 \% \\
\text { for PST on Hard } \\
\text { Costs }\end{array}$ & $\begin{array}{l}\text { The Altus Cost Guide (2015) states that taxes are not } \\
\text { added to their estimations of hard costs. Thus, GST } \\
\text { + PST were applied in order to ensure that the pro } \\
\text { formas remained conservative. That being said, as } \\
\text { taxes as adjusted, the numbers might change, but } \\
\text { the message and findings of this report will remain } \\
\text { the same. }\end{array}$ \\
\hline
\end{tabular}

\section{APPENDIX 2A: \#1 MIXED USE AREAS PRO FORMA ASSUMPTIONS}

All of the assumptions remain the same as in the base case scenario, except for the following:

\section{Land Costs and Assumptions}

\begin{tabular}{|c|c|c|}
\hline Line Item & Assumption & Source \\
\hline $\begin{array}{l}\text { Percentage of } \\
\text { Development that is } \\
\text { Townhouse/ Mixed Use } \\
\text { Portion }\end{array}$ & $\begin{array}{l}\text { 80\% Townhouse, } \\
\text { 20\% Mixed Use Site }\end{array}$ & $\begin{array}{l}\text { This was to allow for a decent site size of just under } \\
4 \text { acres, which is equivalent to what the current } \\
\text { Town of Whitby Zoning By-Law requires for a } \\
\text { mixed-use site. }\end{array}$ \\
\hline $\begin{array}{l}\text { Mixed Use Building } \\
\text { Specifications }\end{array}$ & $\begin{array}{l}\text { Lot Coverage, \# of } \\
\text { floors }\end{array}$ & $\begin{array}{l}\text { In compliance with Whitby Zoning By-law } 2585 \text {, the } \\
\text { Mixed use site had a lot coverage of } 40 \% \text { and is four } \\
\text { stories tall. }\end{array}$ \\
\hline
\end{tabular}




\begin{tabular}{|c|c|c|}
\hline $\begin{array}{l}\text { Average Size of a Condo } \\
\text { Unit(s) }\end{array}$ & $\begin{array}{l}1 \text { bedroom }-800 \\
\text { square feet } \\
2 \text { bedroom }-1200 \\
\text { square feet }\end{array}$ & $\begin{array}{l}\text { Since there are very few new condos being } \\
\text { constructed in Whitby, this report used an average } \\
\text { of prices for similarly sized units for the currently } \\
\text { for sale Harbourside Development in Port Whitby. } \\
\text { The Condo units are located within a four storey } \\
\text { building. (Personal Communication with } \\
\text { Administrative Assistant for Harbourside } \\
\text { Development, March 30, 2015). }\end{array}$ \\
\hline Tenure Mix & $\begin{array}{l}33.3 \% 1 \text { bedroom } \\
66.6 \% 2 \text { bedroom }\end{array}$ & $\begin{array}{l}\text { Since there are very few new condos being } \\
\text { constructed in Whitby, this report uses the unit } \\
\text { ratio }(2: 1) \text { for the currently for sale Harbourside } \\
\text { Development in Port Whitby. The Condo units are } \\
\text { located within a four storey building. (Personal } \\
\text { Communication with Administrative Assistant for } \\
\text { Harbourside Development, March 30, 2015). }\end{array}$ \\
\hline $\begin{array}{l}\text { Selling price per Condo } \\
\text { Unit }\end{array}$ & $\begin{array}{l}1 \text { bedroom - } \\
\$ 319,127 \\
2 \text { bedroom - } \\
\$ 385,990\end{array}$ & $\begin{array}{l}\text { Since there are very few new condos being } \\
\text { constructed in Whitby, this report used an average } \\
\text { of prices for similarly sized units for the currently } \\
\text { for sale Harbourside Development in Port Whitby. } \\
\text { The Condo units are located within a four storey } \\
\text { building and are considered luxury. (Personal } \\
\text { Communication with Administrative Assistant for } \\
\text { Harbourside Development, March } 30,2015 \text { ). }\end{array}$ \\
\hline $\begin{array}{l}\text { Selling price per square } \\
\text { foot of retail }\end{array}$ & $\$ 269$ per square foot & $\begin{array}{l}\text { This information was obtained using a review of } \\
\text { data from "Durham Commercial Real Estate". This } \\
\text { site lists office and retail spaces for lease within the } \\
\text { Region. Using a common industry formula", these } \\
\text { rates were converted to what their selling price } \\
\text { might be and then averaged. There were a total of } \\
\text { five listings from Pickering, Oshawa, Ajax and } \\
\text { Bowmanville. }\end{array}$ \\
\hline GLA (Gross Living Area) & $185,391.36$ sqft & $\begin{array}{l}\text { The Altus Cost Guide, } 2015 \text { advises that in order to } \\
\text { calculate the cost of construction for a building, you } \\
\text { multiply the Gross Floor Area by } 70 \% \text { to get the GLA } \\
\text { (Gross Living Area). This is what is multiplied by } \\
\text { the cost per square foot of the building, as well as } \\
\text { what is available for sale. }\end{array}$ \\
\hline $\begin{array}{l}\text { R.O.W. as a \% of } \\
\text { Subdivision }\end{array}$ & $20.1 \%$ & See Illustration 1: Base Case Scenario \\
\hline
\end{tabular}

2 This formula takes the rent per square foot, multiples it by $70 \%$ (to allow for $30 \%$ to be used for operating costs) then is multiplied by the appropriate CAP Rate. The CAP Rate was obtained from the Colliers "CAP Rate Report" for Q3 from 2014. The CAP Rate selected took the Retail - Community high and low rates and found the median (6.375\%). 
Hard Costs

\begin{tabular}{|l|l|l|}
\hline Line Item & Assumption & Source \\
\hline $\begin{array}{l}\text { of Cousing Materials/Cost } \\
\text { \$195 per sqft }\end{array}$ & $\begin{array}{l}\text { Altus Cost Guide, 2015 "Basic Quality Condo" (High } \\
\text { end estimate). Even though this is a mixed use } \\
\text { building, it is appropriate to use the higher cost per } \\
\text { square foot of the building (which is condo) instead } \\
\text { of the other retail options, which were assumed to } \\
\text { be 1 storey tall and not have other uses on top. } \\
\text { Underground parking is included in this price. }\end{array}$ \\
\hline
\end{tabular}

\section{Soft Costs}

\begin{tabular}{|l|l|l|}
\hline Line Item & Assumption & Source \\
\hline $\begin{array}{l}\text { Development Charges } \\
\text { (Town of Whitby, Region } \\
\text { of Durham and }\end{array}$ & $\begin{array}{l}\text { \$32,963 per } \\
\text { Education) }\end{array}$ & $\begin{array}{l}\text { "Development Charge Schedule" Town of Whitby, } \\
\text { 2014. Retrieved from: } \\
\text { http://whitby.ca/en/resources/csx- } \\
\text { developmentcharbesJuly12014p20140623.pdf }\end{array}$ \\
\hline $\begin{array}{l}\text { Development Charges } \\
\text { (Town of Whitby, Region } \\
\text { of Durham and } \\
\text { Education) }\end{array}$ & $\begin{array}{l}\text { \$12,481 per 1 } \\
\text { bedroom } \\
\text { condominium unit }\end{array}$ & $\begin{array}{l}\text { "Development Charge Schedule" Town of Whitby, } \\
\text { 2014. Retrieved from: } \\
\text { http://whitby.ca/en/resources/csx- } \\
\text { developmentcharbesJuly12014p20140623.pdf }\end{array}$ \\
\hline $\begin{array}{l}\text { Development Charges } \\
\text { (Town of Whitby, Region } \\
\text { of Durham and } \\
\text { Education) }\end{array}$ & $\begin{array}{l}\text { \$25,789 Per 2 } \\
\text { bedroom } \\
\text { condominium unit }\end{array}$ & $\begin{array}{l}\text { "Development Charge Schedule" Town of Whitby, } \\
\text { 2014. Retrieved from: } \\
\text { http://whitby.ca/en/resources/csx- } \\
\text { developmentcharbesJuly12014p20140623.pdf }\end{array}$ \\
\hline $\begin{array}{l}\text { Development Charges } \\
\text { (Town of Whitby and } \\
\text { Region of Durham) }\end{array}$ & $\begin{array}{l}\text { \$15.87 per sqft of } \\
\text { retail space }\end{array}$ & $\begin{array}{l}\text { "Development Charge Schedule" Town of Whitby, } \\
\text { 2014. Retrieved from: } \\
\text { http://whitby.ca/en/resources/csx- } \\
\text { developmentcharbesJuly12014p20140623.pdf }\end{array}$ \\
\hline
\end{tabular}

\section{APPENDIX 2.1A: \#1 MIXED USE AREAS PRO FORMA ASSUMPTIONS - 5\% DEVELOPMENT CHARGE WAIVER}

All of the assumptions remain the same as in Appendix 2B, except for the following:

\section{Soft Costs}

\begin{tabular}{|l|l|l|}
\hline Line Item & Assumption & Source \\
\hline Development Charges & Subtract 5\% from & Development Charges are the most often cited \\
for Townhouse, & each of the listed & barrier to development by those in the industry. \\
Apartment with 1 & Development & Development Charge reductions are frequently \\
bedroom, Apartment & Charge Line Items & $\begin{array}{l}\text { used to encourage certain forms of development by } \\
\text { municipalities across Ontario. 5\% can also be }\end{array}$ \\
Commercial & & altered as needed by the municipality. \\
\hline
\end{tabular}




\section{APPENDIX 2.2A:\#1 MIXED USE AREAS PRO FORMA ASSUMPTIONS - 25\% PARKING REDUCTION}

All of the assumptions remain the same as in Appendix 2B, except for the following:

\section{Hard Costs}

\begin{tabular}{|l|l|l|}
\hline Line Item & Assumption & Source \\
\hline Construction Costs - & Since underground & \$25,000 was obtained from the Victoria \\
Mixed Use Building & parking costs are & Transportation Policy Institute Study done in 2013. \\
included in the & \\
& Altus Guide & \\
Calculations, I & \\
subtracted the & \\
following from the & \\
hard costs total. & \\
& (Total Number of & \\
& Spots required x & \\
& 25\%)* \$25,000 (per \\
& spot) \\
\hline
\end{tabular}

\section{APPENDIX 2.3A: \#1 MIXED USE AREAS PRO FORMA ASSUMPTIONS - ALL INCENTIVES}

All of the assumptions remain the same as in Appendix 2B, and add the assumptions from Appendix 2.1B and 2.2B.

\section{APPENDIX 3A: \#2 WIDE SMOOTH FOOTWAYS PRO FORMA ASSUMPTIONS}

All of the assumptions remain the same as in the base case scenario, except for the following:

\section{Hard Costs}

\begin{tabular}{|c|c|c|}
\hline Line Item & Assumption & Source \\
\hline $\begin{array}{l}\text { Sidewalk (widened to } \\
2 \mathrm{~m} \text { ) }\end{array}$ & $\begin{array}{l}\$ 200 \text { per linear } \\
\text { metre }\end{array}$ & $\begin{array}{l}\text { Personal Communication with established Home } \\
\text { Builder/Developer in Whitby }\end{array}$ \\
\hline $\begin{array}{l}\text { Sidewalk (made with } \\
\text { non-slip materials) } \\
\text { "Large Groove Concrete" }\end{array}$ & $\begin{array}{l}\$ 80 \text { per } \mathrm{m}^{2} \\
\text { At } 1.5 \mathrm{~m} \text { wide }=\$ 120 \\
\text { per linear } \mathrm{m} \\
\text { At } 2 \mathrm{~m} \text { wide }=\$ 160 \\
\text { per linear } \mathrm{m}\end{array}$ & $\begin{array}{l}\text { Personal Communication with PC1 indicated this } \\
\text { cost and personal communication with PC2 } \\
\text { confirmed that this type of pavement is indeed } \\
\text { non-slip and performs much better than typical } \\
\text { materials in a Canadian winter climate. }\end{array}$ \\
\hline
\end{tabular}




\section{APPENDIX 4A: \#3 ROAD CROSSINGS PRO FORMA ASSUMPTIONS}

All of the assumptions remain the same as in the base case scenario, except for the following:

\section{Hard Costs}

\begin{tabular}{|c|c|c|}
\hline Line Item & Assumption & Source \\
\hline $\begin{array}{l}\text { Pedestrian Crossing (for } \\
\text { the intersections } \\
\text { nearest the park, as this } \\
\text { is likely to be where the } \\
\text { most traffic is) }\end{array}$ & $\begin{array}{l}\text { Flashing Beacon } \\
\text { Intersection (\$6625) } \\
\text { Audible Pedestrian } \\
\text { Signal (\$1037.96) } \\
\text { Pedestrian Signal } \\
\text { (\$1255.92) } \\
\text { TOTAL: \$8918.88 }\end{array}$ & $\begin{array}{l}\text { US REPORT "Flashing Beacon" (p.26), "Audible } \\
\text { Pedestrian Signal' (p.27), 'Pedestrian Signal" (p.27), } \\
\text { adjusted for inflation and converted to CAD from } \\
\text { USD. }\end{array}$ \\
\hline $\begin{array}{l}\text { High Visibility } \\
\text { Crosswalk (Zebra Lines } \\
\text { etc) }\end{array}$ & $\begin{array}{l}\$ 3993.85 \text { ( } \mathrm{x} 4 \text { streets } \\
\text { to cross) }=\$ 15,975 \\
\text { per } 4 \text { way } \\
\text { intersection }\end{array}$ & $\begin{array}{l}\text { US REPORT 'High Visibility Crosswalk' (p.24), } \\
\text { adjusted for inflation and converted to CAD from } \\
\text { USD. }\end{array}$ \\
\hline $\begin{array}{l}\text { Striped Crosswalk (Two } \\
\text { lines, extending the path } \\
\text { of the sidewalk in } \\
\text { markings) }\end{array}$ & $\begin{array}{l}\$ 435.64(\mathrm{x} 4 \text { streets } \\
\text { to cross) }=\$ 1742.56 \\
\text { per } 4 \text { way } \\
\text { intersection }\end{array}$ & $\begin{array}{l}\text { US REPORT 'Striped Crosswalk' (p.24), adjusted for } \\
\text { inflation and converted to CAD from USD. }\end{array}$ \\
\hline $\begin{array}{l}\text { Number of Internal } \\
\text { Intersections }\end{array}$ & $\begin{array}{l}2 \text { (of which, } 1 \text { is a } \\
\text { pedestrian crossing } \\
\text { combined with a } \\
\text { Striped Crosswalk } \\
\text { near the park and } 1 \\
\text { is a High Visibility } \\
\text { Crosswalk) }\end{array}$ & Please see Illustration 1: Base Case Scenario \\
\hline $\begin{array}{l}\text { External Intersections } \\
\text { (Fully Signalized with } \\
\$ 10,000 \text { APS (Audible } \\
\text { Pedestrian Signal } \\
\text { upgrade) }\end{array}$ & $\begin{array}{l}\$ 160,000 \text { (of which } \\
\text { the developer will } \\
\text { only be paying } \\
\$ 10,000 \text { per } \\
\text { intersection) }\end{array}$ & $\begin{array}{l}\text { City of Toronto. City Solicitor and General Manager, } \\
\text { Transportation Services. (2008). Staff Report Action } \\
\text { Required: Update on the City's Accessible } \\
\text { Pedestrian Signals (APS) Retrofit Program and an } \\
\text { Ontario Human Rights Complaint Involving the } \\
\text { City's Provision of APS. Retrieved from: } \\
\text { http://www.toronto.ca/legdocs/mmis/2008/pw/bgrd } \\
\text { /backgroundfile-10400.pdf } \\
\text { Upon discussion with PC2, it was indicated that } \\
\text { usually the cost of intersection signalization } \\
\text { typically comes out of the Capital Works budget. } \\
\text { That being said, unless the situation warrants it, } \\
\text { add-ons like APS may not be included, and that is } \\
\text { why it is included on the developer's pro forma } \\
\text { instead. }\end{array}$ \\
\hline $\begin{array}{l}\text { Number of External } \\
\text { Intersections }\end{array}$ & 3 & Please see Illustration 1: Base Case Scenario \\
\hline
\end{tabular}




\section{APPENDIX 5A: \#4 CLEAR SIGNS PRO FORMA ASSUMPTIONS}

All of the assumptions remain the same as in the base case scenario, except for the following:

\section{Hard Costs}

\begin{tabular}{|l|l|l|}
\hline Line Item & Assumption & Source \\
\hline $\begin{array}{l}\text { Street Signs with black } \\
\text { lettering and white } \\
\text { background }\end{array}$ & \$500.00 per sign & As indicated by PC1 and confirmed by PC2. \\
\hline $\begin{array}{l}\text { Number of appropriate } \\
\text { signs }\end{array}$ & $\begin{array}{l}\text { 5 intersections= 20 } \\
\text { signs } \\
\text { 3 places with 3 } \\
\text { signs each = 9 signs } \\
\text { TOTAL: 29 signs }\end{array}$ & $\begin{array}{l}\text { In addition to street signs, the public features that } \\
\text { would be located in this ideal development would } \\
\text { be: Park, Community Post Box, and Bus Stop. } \\
\text { Therefore, there should be signs for each of these } \\
\text { three destinations at each intersection in the } \\
\text { development, as well as at each of the locations. }\end{array}$ \\
\hline
\end{tabular}

\section{APPENDIX 6A: \#5 FREQUENT SEATING PRO FORMA ASSUMPTIONS}

All of the assumptions remain the same as in the base case scenario, except for the following:

\section{Hard Costs}

\begin{tabular}{|l|l|l|}
\hline Line Item & Assumption & Source \\
\hline Cost of bench & \$1000 per bench & As indicated by PC1 and confirmed by PC2. \\
\hline Number of benches & $\begin{array}{l}\text { One per every 125m } \\
\text { of linear road }\end{array}$ & Burton \& Mitchell $(2006$, p. 98) \\
\hline
\end{tabular}

\section{APPENDIX 7A: \#6 SMALL BLOCKS, IRREGULAR GRID + WINDING STEETS PRO FORMA ASSUMPTIONS}

All of the assumptions remain the same as in the base case scenario, except for the following:

\section{Land Costs and Assumptions}

\begin{tabular}{|l|l|l|}
\hline Line Item & Assumption & Source \\
\hline $\begin{array}{l}\text { Roads as a \% of } \\
\text { Subdivision }\end{array}$ & $29.55 \%$ & $\begin{array}{l}\text { Please see Illustration 2: Small Blocks, Irregular Grid } \\
\text { and Winding Streets. }\end{array}$ \\
\hline $\begin{array}{l}\text { Net Number of Lots per } \\
\text { Acre }\end{array}$ & 16.8 per acre & $\begin{array}{l}\text { Gross number of } 6 \mathrm{~m} \times 28 \mathrm{~m} \text { lots in one acre }=24 . \\
\text { This multiplied by 0.799 (to allow for 29.55\% roads) } \\
\text { 19 net lots per acre. *See Illustration 2: Small Blocks, } \\
\text { Irregular Grid + Winding Streets }\end{array}$ \\
\hline
\end{tabular}




\section{APPENDIX 8A: \#7 MARKED LEVEL CHANGES + HANDRAILS PRO FORMA ASSUMPTIONS}

All of the assumptions remain the same as in the base case scenario, except for the following:

\section{Hard Costs}

\begin{tabular}{|l|l|l|}
\hline Line Item & Assumption & Source \\
\hline Curb Ramp & $\begin{array}{l}\text { \$46.95CAD per ramp } \\
\text { (8 per 4-way } \\
\text { intersection) }\end{array}$ & $\begin{array}{l}\text { US REPORT "Truncated Dome/Detectable Warning" } \\
\text { (p19), adjusted for inflation and converted to CAD } \\
\text { from USD. }\end{array}$ \\
\hline Number of Intersections & 5 & Please see Illustration 1: Base Case Scenario \\
\hline
\end{tabular}

\section{APPENDIX 9A: \#8 GROUND LEVEL TOILETS PRO FORMA ASSUMPTIONS}

All of the assumptions remain the same as in the base case scenario, except for the following:

\section{Hard Costs}

\begin{tabular}{|l|l|l|}
\hline Line Item & Assumption & Source \\
\hline $\begin{array}{l}\text { Cost of one ground level } \\
\text { public toilet (to be added } \\
\text { to the park) }\end{array}$ & $\$ 450,000$ & $\begin{array}{l}\text { Haunch, V. "Visit to Toronto's Pricey Automated } \\
\text { Toilet Not Always Flush with Success" Toronto Star. } \\
\text { July } 4^{\text {th }}, 2014 .\end{array}$ \\
\hline
\end{tabular}

\section{APPENDIX 10A: \#9 ENCLOSED BUS SHELTERS PRO FORMA ASSUMPTIONS}

All of the assumptions remain the same as in the base case scenario, except for the following:

\section{Hard Costs}

\begin{tabular}{|l|l|l|}
\hline Line Item & Assumption & Source \\
\hline $\begin{array}{l}\text { Cost of one enclosed bus } \\
\text { shelter }\end{array}$ & $\begin{array}{l}\text { \$8000 per enclosed } \\
\text { bus shelter }\end{array}$ & As indicated by PC1 and confirmed by PC2. \\
\hline
\end{tabular}




\section{APPENDIX 11A: \#10 VARIED URBAN FORM + ARCHITECTURE PRO FORMA ASSUMPTIONS}

All of the assumptions remain the same as in the base case scenario, except for the following:

\section{Soft Costs}

\begin{tabular}{|l|l|l|}
\hline Line Item & Assumption & Source \\
\hline $\begin{array}{l}\text { New House Style Design } \\
\text { by architect* }\end{array}$ & $\begin{array}{l}\text { \$2 per sqft (\$3000 } \\
\text { for a 1500sqft } \\
\text { Townhouse) }\end{array}$ & $\begin{array}{l}\text { Personal Communication with established HB/D in } \\
\text { Whitby }\end{array}$ \\
\hline $\begin{array}{l}\text { New House Model } \\
\text { Design by architect (a } \\
\text { small variation on a } \\
\text { 'Style' as above) }\end{array}$ & $\begin{array}{l}\text { \$0.75 per sqft (\$1125 } \\
\text { for a 1500sqft } \\
\text { Townhouse) }\end{array}$ & $\begin{array}{l}\text { Personal Communication with established HB/D in } \\
\text { Whitby }\end{array}$ \\
\hline $\begin{array}{l}\text { Number of New House } \\
\text { Styles and Models }\end{array}$ & $\begin{array}{l}\text { 2 styles per street } \\
\text { plus 1 extra model } \\
\text { for each }\end{array}$ & $\begin{array}{l}\text { An assumption, in order to provide for maximum } \\
\text { possible legibility for the individual street within } \\
\text { the neighbourhood. }\end{array}$ \\
\hline $\begin{array}{l}\text { One house design per } \\
\text { street (minus 1 to } \\
\text { account for } \\
\text { architectural designs } \\
\text { already included in Base } \\
\text { Case Soft Costs) }\end{array}$ & 3 streets & See Illustration 1: Base Case Scenario \\
\hline
\end{tabular}

*It should be noted that for the sake of understanding, the cost of the new design was the only line item added into the base case. Naturally, with a completely different house design, different materials for the house would be required and the square footage might change, but as the established Home Builder/Developer mentioned, this would be reflected in the price of the house (and for the purposes of this report, not change the IRR).

\section{APPENDIX 12A: \#11 BUFFER ZONES PRO FORMA ASSUMPTIONS}

All of the assumptions remain the same as in the base case scenario as buffer zones were already included in it.

\section{APPENDIX 13A: \#12 LANDMARKS + PLACES OF ACTIVITY PRO FORMA ASSUMPTIONS}

All of the assumptions remain the same as in the base case scenario, except for the following:

\section{Hard Costs*}

\begin{tabular}{|l|l|l|}
\hline Line Item & Assumption & Source \\
\hline $\begin{array}{l}\text { Community Post Box } \\
\text { pavilion with seating } \\
\text { and electrical outlets }\end{array}$ & \$22,000 per Pavilion & $\begin{array}{l}\text { As indicated by PC2 and an example is shown in } \\
\text { Figure 7. }\end{array}$ \\
\hline
\end{tabular}

*For this section, the report examines a number of ways landmarks could be created within a subdivision. For the purposes of this report, the landmark section will only include the Community Post Box, but as the Literature reveals, landmarks could also double as recommendations from the core list - such as bus stops, public seating, signage and the features listed to be placed at junctions. Many of the aspects are estimations, and could be required by the Town in order to produce landmarks within the subdivision. 


\section{APPENDIX 14A: \#14 DISTINCTIVE FEATURES AT JUNCTIONS PRO FORMA ASSUMPTIONS}

All of the assumptions remain the same as in the base case scenario, except for the following:

Hard Costs*
\begin{tabular}{|l|l|l|}
\hline Line Item & Assumption & Source \\
\hline $\begin{array}{l}\text { Landscaped Median (3m } \\
\mathrm{x} 3 \mathrm{~m})\end{array}$ & $\$ 375$ each & $\begin{array}{l}\text { As indicated by PC1 and confirmed by PC2. One per } \\
\text { external intersection as a means to slow down } \\
\text { traffic. }\end{array}$ \\
\hline $\begin{array}{l}\text { Flower Pots with } \\
\text { Plantings (3ftx3f) }\end{array}$ & $\$ 1500$ each & $\begin{array}{l}\text { As indicated by PC1 and confirmed by PC2. Two per } \\
\text { internal intersection. }\end{array}$ \\
\hline Trellis & $\$ 15,000$ per Trellis & $\begin{array}{l}\text { As indicated by PC1 and confirmed by PC2. One per } \\
\text { development. }\end{array}$ \\
\hline
\end{tabular}

*For this section, the report examines a number of ways distinctive features at junctions could be incorporated into a subdivision. Many of the aspects are estimations, and could be required by the Town.

\section{APPENDIX 15A: EVERYTHING EXCEPT MIXED USE (THE EFFECT OF RECOMMENDATIONS \#2 - \#17) PRO FORMA ASSUMPTIONS}

In order to incorporate all of the recommendations except Mixed Use (\#2-17) into one Pro Forma, it was necessary to escalate a few of the costs, due to the change in percentage of roads, number of intersections and number of streets within the new design (shown in Illustration \#2 - Small Blocks, Irregular Grid and Winding Streets). The assumptions were thus changed as indicated below:

\section{Land Costs and Assumptions}

\begin{tabular}{|l|l|l|}
\hline Line Item & Assumption & Source \\
\hline $\begin{array}{l}\text { Roads as a of } \\
\text { Subdivision }\end{array}$ & $29.55 \%$ & $\begin{array}{l}\text { Please see Illustration \#2: Small Blocks, Irregular } \\
\text { Grid and Winding Streets. }\end{array}$ \\
\hline $\begin{array}{l}\text { Net Number of Lots per } \\
\text { Acre }\end{array}$ & 16.8 per acre & $\begin{array}{l}\text { Gross number of } 6 \mathrm{~m} \times 28 \mathrm{~m} \text { lots in one acre }=24 . \\
\text { This multiplied by } 0.7045 \text { (to allow for 29.55\% roads) } \\
=16.8 \text { net lots per acre. * See Illustration 2: Small } \\
\text { Blocks, Irregular Grid + Winding Streets }\end{array}$ \\
\hline
\end{tabular}




\section{Hard Costs}

\begin{tabular}{|l|l|l|}
\hline Line Item & Assumption & Source \\
\hline $\begin{array}{l}\text { Number of Internal } \\
\text { Intersections }\end{array}$ & $\begin{array}{l}7 \text { (of which, 1 is a } \\
\text { pedestrian crossing } \\
\text { combined with a } \\
\text { Striped Crosswalk } \\
\text { near the park and 6 } \\
\text { are High Visibility } \\
\text { Crosswalks) }\end{array}$ & $\begin{array}{l}\text { Please see Illustration 2: Small Blocks, Irregular Grid } \\
\text { and Winding Streets. }\end{array}$ \\
\hline $\begin{array}{l}\text { Number of External } \\
\text { Intersections }\end{array}$ & 5 & $\begin{array}{l}\text { Please see Illustration 2: Small Blocks, Irregular Grid } \\
\text { and Winding Streets. }\end{array}$ \\
\hline $\begin{array}{l}\text { Total Number of } \\
\text { Intersections }\end{array}$ & 12 & $\begin{array}{l}\text { Please see Illustration 2: Small Blocks, Irregular Grid } \\
\text { and Winding Streets. }\end{array}$ \\
\hline $\begin{array}{l}\text { Number of appropriate } \\
\text { signs }\end{array}$ & $\begin{array}{l}12 \text { intersections }=48 \\
\text { signs } \\
3 \text { places with 3 } \\
\text { signs each }=9 \text { signs } \\
\text { TOTAL: } 57 \text { signs }\end{array}$ & $\begin{array}{l}\text { In addition to street signs, the public features that } \\
\text { would be located in this ideal development would } \\
\text { be: Park, Community Post Box, and Bus Stop. } \\
\text { Therefore, there should be signs for each of these } \\
\text { three destinations at each intersection in the } \\
\text { development, as well as at each of the locations. }\end{array}$ \\
\hline $\begin{array}{l}\text { One house design per } \\
\text { street (minus 1 to } \\
\text { account for } \\
\text { architectural designs } \\
\text { already included in Base } \\
\text { Case Soft Costs) }\end{array}$ & 5 streets & $\begin{array}{l}\text { Please see Illustration 2: Small Blocks, Irregular Grid } \\
\text { and Winding Streets. }\end{array}$ \\
\hline
\end{tabular}

\section{APPENDIX 16A: EVERYTHING (THE EFFECT OF RECOMMENDATIONS \#1 - \#17) PRO FORMA ASSUMPTIONS}

In order to incorporate all of the recommendations (\#1-17) into one Pro Forma, it was necessary to escalate a few of the costs, due to the change in percentage of roads, number of intersections and number of streets within the new design (shown in Illustration \#2 Small Blocks, Irregular Grid and Winding Streets). All of the assumptions remain the same as in Appendix 15B, except for the following:

\section{Hard Costs}

\begin{tabular}{|l|l|l|}
\hline Line Item & Assumption & Source \\
\hline $\begin{array}{l}\text { Number of appropriate } \\
\text { signs }\end{array}$ & $\begin{array}{l}\text { 12 intersections }=48 \\
\text { signs } \\
4 \text { places with 4 } \\
\text { signs each = 16 } \\
\text { signs } \\
\text { TOTAL: 64 signs }\end{array}$ & $\begin{array}{l}\text { In addition to street signs, the public features that } \\
\text { would be located in this ideal development would } \\
\text { be: Park, Community Post Box, Shops (in mixed use } \\
\text { building) and Bus Stop. Therefore, there should be } \\
\text { signs for each of these three destinations at each } \\
\text { intersection in the development, as well as at each } \\
\text { of the locations. }\end{array}$ \\
\hline
\end{tabular}




\section{APPENDIX 17A: EVERYTHING (THE EFFECT OF RECOMMENDATIONS \#1 - \#17) WITH INCENTIVES PRO FORMA ASSUMPTIONS}

All of the assumptions remain the same as in Appendix 16B, except for the following:

\section{Soft Costs}

\begin{tabular}{|l|l|l|}
\hline Line Item & Assumption & Source \\
\hline $\begin{array}{l}\text { Development Charges } \\
\text { for Townhouse, }\end{array}$ & $\begin{array}{l}\text { Subtract 15\% from each of } \\
\text { Apartment with 1 } \\
\text { bedroom, Apartment }\end{array}$ & $\begin{array}{l}\text { Development Charges are the most often } \\
\text { charge Line Items }\end{array}$ \\
$\begin{array}{l}\text { cith 2 bedrooms \& } \\
\text { Commercial }\end{array}$ & & $\begin{array}{l}\text { industry. Development Charge reductions } \\
\text { are frequently used to encourage certain } \\
\text { forms of development by municipalities }\end{array}$ \\
& & $\begin{array}{l}\text { across Ontario. 15\% can also be altered as } \\
\text { needed by the municipality. }\end{array}$ \\
\hline
\end{tabular}

\section{Hard Costs}

\begin{tabular}{|c|c|c|}
\hline Line Item & Assumption & Source \\
\hline $\begin{array}{l}\text { Construction Costs - } \\
\text { Mixed Use Building }\end{array}$ & $\begin{array}{l}\text { Since underground parking } \\
\text { costs are included in the } \\
\text { Altus Guide Calculations, I } \\
\text { subtracted the following } \\
\text { from the hard costs total. } \\
\text { (Total Number of Spots } \\
\text { required x } 25 \% \text { ) } \$ 25,000 \\
\text { (per spot) }\end{array}$ & $\begin{array}{l}\$ 25,000 \text { was obtained from the Victoria } \\
\text { Transportation Policy Institute Study done } \\
\text { in } 2013 \text {. }\end{array}$ \\
\hline
\end{tabular}




\begin{tabular}{|c|c|c|c|}
\hline \multicolumn{4}{|l|}{ LAND COSTS } \\
\hline Average Land Cost (per acre)* & $\$ 500,000$ & & *P.C. Home Builder/Developer \\
\hline Land Area & 20 & acres & \\
\hline Parkland Dedication & $5 \%$ & & \\
\hline Developable Land & 19.0 & acres & \\
\hline \multicolumn{4}{|l|}{ BUILT FORM ASSUMPTIONS } \\
\hline Average Townhouse Size* & 1500 & sqft & *P.C. Home Builder/Developer \\
\hline \# of Residential Lots & 19 & $\begin{array}{l}\text { net per } \\
\text { acre }\end{array}$ & *Base Case Assumption (see Appendix 1B) \\
\hline Average Price of Home & $\$ 400,000$ & per house & *P.C. Home Builder/Developer \\
\hline \multicolumn{4}{|l|}{ ROAD CALCULATION } \\
\hline Roads as $\%$ of subdivision & $20.1 \%$ & & *Assumption (See Illustration \#1-Base Case Scenario) \\
\hline Roads as acres & 4.02 & & acres \\
\hline Roads in square meters & 4047 & & $\mathrm{~m}^{2}$ \\
\hline $\begin{array}{l}\text { Linear metres of Road (Standard of } \\
18 \mathrm{~m} \text { width) }\end{array}$ & 18 & & linear $\mathrm{m}$ \\
\hline \multicolumn{4}{|l|}{ FINANCING } \\
\hline Construction Loan Cost & $10 \%$ & \multicolumn{2}{|c|}{${ }^{*}$ Base Case Assumption (see Appendix 1A) } \\
\hline $\begin{array}{l}\text { Contingency Fund (on hard/soft } \\
\text { costs) }\end{array}$ & $5 \%$ & \multicolumn{2}{|c|}{ *P.C. Home Builder/Developer } \\
\hline Equity & $25 \%$ & \multicolumn{2}{|c|}{ *P.C. Home Builder/Developer } \\
\hline GST (per construction costs) & $5 \%$ & \multicolumn{2}{|c|}{${ }^{*}$ Altus Guide, 2015} \\
\hline PST (per construction costs) & $8 \%$ & \multicolumn{2}{|c|}{ *Altus Guide, 2015} \\
\hline
\end{tabular}

HARD COSTS

Road Construction including asphalt and ALL utilities

underneath (per $\mathrm{m}$ of $8.5 \mathrm{~m}$ wide road)*

Sidewalk cost per linear $\mathrm{m}\left(1.5 \mathrm{~m}\right.$ wide cement) ${ }^{\star}$

Buffer Zone cost per linear $\mathrm{m}$ (3m wide grass and trees)*

Street Lighting (including Hydro connections to lot line) ${ }^{\star}$

Tree Planting (on lots only, about 0.8 trees per lot)*

Housing Materials/Labor Cost*

Hook up Cost

\section{SOFT COSTS}

Soft Costs (as estimated by developer)*

\begin{tabular}{|l|}
\hline Town of Whitby DC \\
\hline Region of Durham DC \\
\hline Educational DC \\
\hline Development Charges Total Per Unit \\
\hline
\end{tabular}

\begin{tabular}{|c|c|c|}
\hline$\$ 2,300$ & per $\mathrm{m}$ & \begin{tabular}{|l} 
*P.C. Home \\
Builder/Developer
\end{tabular} \\
\hline$\$ 150$ & per $\mathrm{m}$ & $\begin{array}{l}\text { *P.C. Home } \\
\text { Builder/Developer }\end{array}$ \\
\hline$\$ 89$ & per $\mathrm{m}$ & $\begin{array}{l}\text { *P.C. Home } \\
\text { Builder/Developer }\end{array}$ \\
\hline$\$ 280$ & per metre & $\begin{array}{l}\text { *P.C. Home } \\
\text { Builder/Developer }\end{array}$ \\
\hline$\$ 400$ & 0.8 & *P.C. Home \\
\hline$\$ 98$ & /sqft & *P.C. Home \\
\hline$\$ 3,864$ & per lot & ×Town of Newmarket \\
\hline$\$ 50.70$ & $\begin{array}{l}\text { per square foot of } \\
\text { house }\end{array}$ & $\begin{array}{l}\text { ×P.C. Home } \\
\text { Builder/Developer }\end{array}$ \\
\hline$\$ 9,479$ & $\begin{array}{l}{ }^{*} \text { Townhouse Dwelling } \\
\text { w } 3 \text { or + bedrooms }\end{array}$ & \\
\hline$\$ 20,749$ & $\begin{array}{l}\text { *Medium Density } \\
\text { Multiples }\end{array}$ & \\
\hline$\$ 2,735$ & ${ }^{\star}$ per dwelling unit & \\
\hline$\$ 32,963$ & & 'Town of Whitby, 2014 \\
\hline
\end{tabular}




\section{APPENDIX 1B - BASE CASE PRO FORMA}

\begin{tabular}{|c|c|c|c|}
\hline \multicolumn{4}{|l|}{ LAND COSTS } \\
\hline Land Area (acre) & & 20.0 & \\
\hline Developable Land & & 19.0 & \\
\hline \multicolumn{2}{|l|}{ Average Land Cost (per acre) } & $\$ 500,000$ & \\
\hline Land Cost & & $\$ 10,000,000$ & \\
\hline \multicolumn{4}{|c|}{ BUILT FORM ASSUMPTIONS } \\
\hline Average Townhouse Size & 1500 & sqft & \\
\hline $\begin{array}{l}\text { \# of Residential Lots } \\
\text { (net/acre) }\end{array}$ & 19 & 361 & \\
\hline Average Price of Home & & $\$ 400,000$ & \\
\hline Total expected Revenues & & $\$ 144,400,000$ & \\
\hline $\begin{array}{l}\text { Total Linear Metres of } \\
\text { Roads }\end{array}$ & & 904 & \\
\hline \multicolumn{4}{|l|}{ ROAD CALCULATION } \\
\hline Roads as \% of subdivision* & $20 \%$ & & \\
\hline Roads as acres & & 4.02 & acres \\
\hline $\begin{array}{l}\begin{array}{l}\text { Roads in } \mathrm{m} 2 \\
\text { (1acre }=4046 \mathrm{~m})\end{array} \\
\end{array}$ & 4047 & 16268.94 & $\mathrm{~m}^{2}$ \\
\hline $\begin{array}{l}\text { Linear metres of Road } \\
\text { (Standard of } 18 \mathrm{~m} \text { width) }\end{array}$ & 18 & 903.83 & $\mathrm{~m}$ \\
\hline
\end{tabular}

\section{HARD COSTS}

Road Construction

\begin{tabular}{|l|l|l|l|l|}
\hline Road Construction & $\$ 2,300$ & per $m$ & $\$ 2,078,809$ \\
\hline
\end{tabular}

Sidewalk (1.5m wide)

Buffer Zone (10ft wic

\begin{tabular}{ll|l|l} 
Street Lighting + Hydro & $\$ 280$ & per m & $\$ 253,072$
\end{tabular}

\begin{tabular}{|l|l|l|l|}
\hline Tree Planting ( 0.8 per lot) & $\$ 400$ & 0.8 & $\$ 115,520$
\end{tabular}

\begin{tabular}{|l|l|l|l}
\hline Housing Materials/ Labor & & & \\
\hline 98 & /sqft & $\$ 53,067,000$
\end{tabular}

Cost

\begin{tabular}{|l|l|l|l|}
\hline Hook up cost & $\$ 3,864$ & per lot & $\$ 1,394,904$ \\
\hline
\end{tabular}

Develo
Total

\section{SOFT COSTS}

Soft Costs (per sqft of

house)

Town of Whitby DC

Region of Durham DC

\begin{tabular}{l} 
Region of Durham \\
\hline Educational DC
\end{tabular}

Development Charges

\begin{tabular}{|l|l|l|} 
& $\$ 50.70$ & $\$ 27,454,050$ \\
\hline & & \\
\hline DC & $\$ 20,749$ & \\
& $\$ 2,735$ & \\
\hline ges & $\$ 32,963$ & $\$ 11,899,643$ \\
\hline
\end{tabular}

TOTAL HARD COSTS

-

\begin{tabular}{|l}
\hline TOTAL SOFT COSTS \\
$\$ 39,353,693.00$
\end{tabular}

\begin{tabular}{|l|l|l|}
\hline FINANCING \\
\hline Land + Hard + Soft Costs Total & & $\$ 106,479,013.77$ \\
\hline Construction Loan Cost & $10 \%$ & $\$ 10,647,901$ \\
\hline $\begin{array}{l}\text { Contingency Fund (on hard/soft } \\
\text { costs) }\end{array}$ & $5 \%$ & $\$ 4,823,951$ \\
\hline GST + PST & & $\$ 7,426,291.70$ \\
\hline Total Costs & & $\$ 129,377,158$ \\
\hline Equity & $25 \%$ & $\$ 32,344,289.38$ \\
\hline RATE OF RETURN & & $\$ 15,022,842$ \\
\hline
\end{tabular}




\begin{tabular}{|c|c|c|c|}
\hline \\
\hline Land Area (acre) & & 20.0 & \\
\hline Developable Land & & 19.0 & \\
\hline Average Land Cost (per acre) & & $\$ 500,000$ & \\
\hline Land Cost & & $\$ 10,000,000.00$ & \\
\hline \multicolumn{4}{|l|}{ BUILT FORM ASSUMPTIONS } \\
\hline Average Townhouse Size & 1500 & sqft & \\
\hline \multirow[t]{2}{*}{ \# of Residential Lots (net/acre) } & 19 & & \\
\hline & & $\$ 400,000$ & \\
\hline Total expected Revenues & & $\$ 115,520,000$ & \\
\hline Total Linear Metres of Roads & & & \\
\hline \% of Development Townhouse & 0.8 & 15.2 & acres \\
\hline \% of Development Mixed Use & 0.2 & 3.8 & acres \\
\hline Mixed Use Lot Coverage & $40 \%$ & 165528 & sqft \\
\hline 1 Floor GFA $=$ & & 66211.2 & sqft \\
\hline Floors (Above Ground) & 4 & & \\
\hline Gross Floor Area & 264845 & sqft & \\
\hline GLA ( $70 \%$ of GFA) & $70 \%$ & 185391.36 & sqft \\
\hline 1 Floor GLA $=$ & & 46347.84 & \\
\hline Residential GLA (3 Floors) & 3 & 139043.52 & \\
\hline 1 bedroom (800sqft) & $33 \%$ & 46301.49216 & sqft \\
\hline \# of 1 bedroom units & 800 & 58 & units \\
\hline Average Sale Price of $800 \mathrm{sqft}$ unit & & $\$ 319,127$ & \\
\hline Residential Revenues & & $\$ 18,470,051$ & \\
\hline 2 bedroom (1200sqft) & $67 \%$ & 92602.98432 & sqft \\
\hline \# of 2 bedroom units & 1200 & & units \\
\hline Average Sale Price of 1200 sqft unit & & $\$ 385,990$ & \\
\hline Residential Revenues & & $\$ 29,786,522$ & \\
\hline Retail GLA (1 Floor) & 1 & 46347.84 & sqft \\
\hline Retail Cost per sqft & $\$ 274$ & $\begin{array}{l}40431,04 \\
\$ 12,699,308 \\
\end{array}$ & \\
\hline \multicolumn{4}{|l|}{ ROAD CALCULATION } \\
\hline Roads as \% of subdivision & $20.1 \%$ & & \\
\hline Roads as acres & & 3.06 & acres \\
\hline Roads in m2 (lacre $=4046 \mathrm{~m}$ ) & 4047 & 12364.3944 & \\
\hline $\begin{array}{l}\text { Linear metres of Road (Standard of } \\
18 \mathrm{~m} \text { width) }\end{array}$ & 18 & 686.9108 & \\
\hline
\end{tabular}

\begin{tabular}{|c|c|c|c|c|c|c|}
\hline \multicolumn{4}{|l|}{ HARD COSTS } & \multicolumn{3}{|l|}{ SOFT COSTS } \\
\hline Road Construction & $\$ 2,300$ & per $\mathrm{m}$ & $\$ 1,579,895$ & Soft Costs For Towns (per sqft house) & $\$ 50.70$ & $\$ 21,963,240$ \\
\hline Sidewalk (1.5m wide) & $\$ 150$ & per $m$ & $\$ 103,037$ & $\begin{array}{l}\text { Soft Costs for Mixed Use (of Hard } \\
\text { costs) }\end{array}$ & $30 \%$ & $\$ 10,845,394.56$ \\
\hline Buffer Zone (10ft wide) & $\$ 89$ & per $\mathrm{m}$ & $\$ 61,135$ & TOWNHOUSE DCs & & \\
\hline Street Lighting + Hydro & $\$ 280$ & per metre & $\$ 192,335$ & Town of Whitby DC & $\$ \$ 9,479$ & \\
\hline Tree Planting (0.8 per lot) & $\$ 400$ & 0.8 & $\$ 92,416$ & Region of Durham DC & $\$ 20,749$ & \\
\hline Housing Materials/Labor Cost -Townhouse & $\$ 98$ & $/ \mathrm{sqft}$ & $\$ 42,453,600$ & Educational DC & $\$ 2,735$ & \\
\hline Hook Up Costs & $\$ 3,864$ & per lot & $\$ 1,115,923$ & DC Total Per Townhouse & $\$ 32,963$ & $\$ 9,519,714$ \\
\hline $\begin{array}{l}\text { Mixed Use Building Materials/Labor } \\
\text { (Multiplied by GLA) }\end{array}$ & $\$ 195$ & per sqft & $\$ 36,151,315$ & CONDO DCs (1 bedroom) & & \\
\hline & & & & Town of Whitby DC & $\$ 4,503$ & \\
\hline & & & & Region of Durham DC & $\$ 9,746$ & \\
\hline & & & & \begin{tabular}{|l|} 
Educational DC \\
TCton Dor \\
\end{tabular} & $\begin{array}{l}\$ 2,735 \\
10201\end{array}$ & (1) \\
\hline & & & & \begin{tabular}{|l|} 
DC Total Per Condo \\
CONDD DCs (2 bedroom)
\end{tabular} & $\$ 12,481$ & |\$722,361.15 \\
\hline & & & & Town of Whitby DC & $\$ 8,063$ & \\
\hline & & & & Region of Durham DC & $\$ 14,991$ & \\
\hline TOTAL HARD COSTS & & & $\$ 81,749,655.95$ & Educational DC & $\$ 2,735$ & \\
\hline & & & & DC Total Per Condo & $\$ 25,789$ & $\$ 1,990,1115.30$ \\
\hline & & & & RETAIL DCs & & \\
\hline & & & & Town of Whitby & $\$ 2.82$ & \\
\hline & & & & Region of Durham & $\$ 13.05$ & \\
\hline & & & & \begin{tabular}{|l|} 
Educational \\
\end{tabular} & $\$ \$ 0$ & 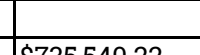 \\
\hline & & & & \begin{tabular}{|l} 
DC Total Per Retail Sqft \\
\end{tabular} & & \$\$735,540.22 \\
\hline
\end{tabular}

TOTAL SOFT COSTS
FINANCING

Land + Hard + Soft Costs Tot

\begin{tabular}{|l|l|l|}
\hline Construction Loan Cost & $10 \%$ & $\$ 13,752,602$ \\
\hline
\end{tabular}

\begin{tabular}{|l|l|l|}
\hline Contingency Fund (on hard/soft & $5 \%$ & $\$ 6,376,301$ \\
\hline
\end{tabular}

\begin{tabular}{|l|}
\hline costs) \\
\hline GST + PST \\
\hline Tot Costs \\
\hline
\end{tabular}

\begin{tabular}{l|l|l} 
& & $\$ 162,27,4527$ \\
\hline Equity & & $\$ 168,282,380$ \\
\hline & & $\$ 2070,59502$
\end{tabular}

RATE OF RETURN

Revenues - costs (cash flow)

$\$ 8,193,501$

Cash flow / Equity (ROE) 


\begin{tabular}{|c|c|c|c|}
\hline \multicolumn{4}{|l|}{ LAND COSTS } \\
\hline Land Area (acre) & & 20.0 & \\
\hline Developable Land & & 19.0 & \\
\hline Average Land Cost (per acre) & & $\$ 500,000$ & \\
\hline \multirow{2}{*}{\multicolumn{4}{|c|}{$\begin{array}{l}\text { Land cost } \\
\text { BUILT FORM ASSUMPTIONS }\end{array}$}} \\
\hline & & & \\
\hline Average Townhouse Size & 1500 & sqft & \\
\hline \multirow[t]{2}{*}{ \# of Residential Lots (net/acre) } & 19 & 289 & \\
\hline & & $\$ 400,000$ & \\
\hline Total expected Revenues & & $\$ 115,520,000$ & \\
\hline Total Linear Metres of Roads & & & \\
\hline$\%$ of Development Townhouse & 0.8 & 15.2 & acres \\
\hline$\%$ of Development Mixed Use & 0.2 & 3.8 & \\
\hline \begin{tabular}{|l|} 
Mixed Use Lot Coverage \\
\end{tabular} & $40 \%$ & 165528 & sqft \\
\hline 1 Floor $\mathrm{GFA}=$ & & 66211.2 & sqft \\
\hline Floors (Above Ground) & 4 & & \\
\hline Gross Floor $A$ & 264845 & sqft & \\
\hline GLA (70\% of GFA) & $70 \%$ & 185391.36 & sqft \\
\hline 1 Floor GLA $=$ & & 46347.84 & sqft \\
\hline Residential GLA (3 Floors) & 3 & 139043.52 & sqft \\
\hline 1 bedroom (800sqft) & $33 \%$ & 46301.49216 & \\
\hline$\#$ of 1 bedroom units & 800 & 58 & units \\
\hline Average Sale Price of 800 sqft unit & & $\$ 319,127$ & \\
\hline Residential Revenues & & $\$ 18,470,051$ & \\
\hline 2 bedroom (1200sqft) & $67 \%$ & 92602.98432 & sqft \\
\hline \# of 2 bedroom units & 1200 & 77 & \\
\hline Average Sale Price of 1200 sqft unit & & $\$ 385,990$ & \\
\hline Residential Revenues & & $\$ 29,786,522$ & \\
\hline Retail GLA (1 Floor) & & 46347.84 & sqft \\
\hline Retail Cost per sqft & $\$ 274$ & $\$ 12,699,308$ & \\
\hline \multicolumn{4}{|l|}{ ROAD CALCULATION } \\
\hline Roads as \% of subdivision & $20.1 \%$ & & \\
\hline Roads as acres & & 3.06 & acre \\
\hline Roads in m2 (lacre=4046m) & 4047 & 12364.3944 & \\
\hline $\begin{array}{l}\text { Linear metres of Road (Standard of } \\
\text { 18m width) }\end{array}$ & f18 & 686.9108 & \\
\hline
\end{tabular}

\begin{tabular}{|c|c|c|c|c|c|c|}
\hline \multicolumn{4}{|l|}{ HARD COSTS } & \multicolumn{3}{|l|}{ SOFT COSTS } \\
\hline Road Construction & $\$ 2,300$ & per $m$ & $\$ 1,579,895$ & Soft Costs For Towns (per sqft house) & $\$ 50.70$ & $\$ 21,963,240$ \\
\hline Sidewalk (1.5m wide) & $\$ 150$ & per $\mathrm{m}$ & $\$ 103,037$ & \begin{tabular}{|l}
$\begin{array}{l}\text { Soft Costs for Mixed Use (of Hard } \\
\text { Costs) }\end{array}$ \\
\end{tabular} & $30 \%$ & $\$ 10,845,394.56$ \\
\hline Buffer Zone (10ft wide) & $\$ 89$ & per $\mathrm{m}$ & $\$ 61,135$ & \multicolumn{3}{|l|}{ TOWNHOUSE DCs (5\% Reduction) } \\
\hline Street Lighting + Hydro & $\$ 280$ & per metre & $\$ 192,335$ & Town of Whitby DC & \$\$9,479 & \\
\hline Tree Planting ( 0.8 per lot $)$ & $\$ 400$ & 0.8 & $\$ 92,416$ & Region of Durham DC & $\$$ \$20,749 & \\
\hline Housing Materials/Labor Cost -Townhouse & $\$ 98$ & /sqft & $\$ 42,453,600$ & Educational DC & $\$ 2,735$ & \\
\hline Hook Up Costs & $\$ 3,864$ & per lot & $\$ 1,115,923$ & DC Total Per Townhouse & $\$ 32,963$ & $\$ 9,043,729$ \\
\hline $\begin{array}{l}\text { Mixed Use Building Materials/Labor } \\
\text { (Multinlied bG GLA) }\end{array}$ & $\$ 195$ & per sqft & $\$ 36,151,315$ & \multicolumn{3}{|c|}{ CONDO DCs (1 bedroom) (5\% Reduction) } \\
\hline & & & & Town of Whitby DC & $\$ 4,503$ & \\
\hline & & & & Region of Durham DC & $\$ 9,746$ & \\
\hline & & & & \begin{tabular}{|l|} 
Educational DC \\
\end{tabular} & $\$ 2,735$ & \\
\hline & & & & DC Total Per Condo & $\$ 12,481$ & $\$ 686,243.10$ \\
\hline & & & & \multicolumn{3}{|c|}{ CONDO DCs ( 2 bedroom) (5\% Reduction) } \\
\hline & & & & Town of Whitby DC & $\$ \$ 8,063$ & \\
\hline & & & & Region of Durham DC & $\$ 14,991$ & \\
\hline \multirow[t]{7}{*}{ TOTAL HARD COSTS } & & & $\$ 81,749,655.95$ & Educational DC & $\$ 2,735$ & \\
\hline & & & & \begin{tabular}{|l} 
DC Total Per Condo \\
\end{tabular} & $\$ 25,789$ & $\$ 1,890,609.54$ \\
\hline & & & & \multicolumn{3}{|l|}{ RETAIL DCs (5\% Reduction) } \\
\hline & & & & Town of Whitby & $\$ 2.82$ & \\
\hline & & & & Region of Durham & $\$ 13.05$ & \\
\hline & & & & Educational & $\$ 0$ & \\
\hline & & & & DC Total Per Retail Sqft & $\$ 15.87$ & $\begin{array}{l}\$ 698,763.21 \\
\end{array}$ \\
\hline
\end{tabular}

TOTAL SOFT COSTS
FINANCING

\begin{tabular}{|l|l|l|l|l|l|l|}
\hline Land + Hard + Soft Costs Total & & $\$ 136,877,63503$ \\
\hline
\end{tabular}

\begin{tabular}{|l|l|l|l|}
\hline Construction Loan Cost & $10 \%$ & $\$ 13,687,764$ \\
\hline
\end{tabular}

\begin{tabular}{|l|l|l|}
\hline Contingency Fund (on hard/soft & $5 \%$ & $\$ 6,343,882$ \\
\hline
\end{tabular}

\begin{tabular}{l} 
costs) \\
\hline GST + PST \\
\hline COS
\end{tabular}

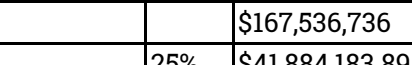

RATE OF RETURN

\begin{tabular}{|l|l|l|l|l|l}
\hline Revenues - costs (cash flow) & & $\$ 8,939,145$ \\
\hline
\end{tabular}

Cash flow / Equity (ROE)

$8,939,145$

\section{LEGEND}

Incentives 


\begin{tabular}{|c|c|c|c|}
\hline \multicolumn{4}{|l|}{ LAND COSTS } \\
\hline Land Area (acre) & & 20.0 & \\
\hline Developable Land & & 19.0 & \\
\hline Average Land Cost (per acre) & & $\$ 500,000$ & \\
\hline Land Cost & & $\$ 10,000,000.00$ & \\
\hline \multicolumn{4}{|l|}{ BUILT FORM ASSUMPTIONS } \\
\hline \multirow{3}{*}{$\begin{array}{l}\text { Average Townhouse Size } \\
\# \text { of Residential Lots (net/acre) }\end{array}$} & 1500 & sqft & \\
\hline & 19 & 289 & \\
\hline & & $\$ 400,000$ & \\
\hline Total expected Revenues & & $\$ 115,520,000$ & \\
\hline Total Linear Metres of Roads & & 687 & \\
\hline \% of Development Townhouse & 0.8 & 15.2 & \\
\hline$\%$ of Development Mixed Use & & 38 & \\
\hline Mixed Use Lot Coverage & $40 \%$ & $\mid .0$ & \\
\hline 1 Floor GFA $=$ & & 66211.2 & sqft \\
\hline Floors (Above Ground) & 4 & & \\
\hline Gross Floor Area & 264845 & sqft & \\
\hline GLA (70\% of GFA) & $70 \%$ & 185391.36 & sqft \\
\hline 1 Floor GLA $=$ & & 46347.84 & \\
\hline Residential GLA (3 Floors) & 3 & 139043.52 & \\
\hline 1 bedroom (800sqft) & $33 \%$ & 46301.49216 & \\
\hline \# of 1 bedroom units & 800 & & \\
\hline Average Sale Price of 800 sqft unit & & $\$ 319,127$ & \\
\hline Residential Revenues & & $\$ 18,470,051$ & \\
\hline 2 bedroom (1200sqft) & $67 \%$ & 92602.98432 & sqft \\
\hline$\#$ of 2 bedroom units & 1200 & 77 & \\
\hline Average Sale Price of 1200 sqft unit & & $\$ 385,990$ & \\
\hline Residential Revenues & & $\$ 29,786,522$ & \\
\hline Retail GLA (1 Floor) & & 46347.84 & sqft \\
\hline Retail Cost per sqft & $\$ 274$ & $\$ 12,699,308$ & \\
\hline \multicolumn{4}{|l|}{ ROAD CALCULATION } \\
\hline Roads as \% of subdivision & $20.1 \%$ & & \\
\hline Roads as acres & & 3.06 & \\
\hline Roads in m2 (1acre $=4046 \mathrm{~m}$ ) & 4047 & 12364.3944 & $\mathrm{~m}^{2}$ \\
\hline $\begin{array}{l}\text { Linear metres of Road (Standard of } \\
18 \mathrm{~m} \text { width) }\end{array}$ & & 686.9108 & $\mathrm{~m}$ \\
\hline
\end{tabular}

\begin{tabular}{|c|c|c|c|c|c|c|}
\hline \multicolumn{4}{|l|}{ HARD COSTS } & \\
\hline Road Construction & $\$ 2,300$ & per $\mathrm{m}$ & $\$ 1,579,895$ & Soft Costs For Towns (per sqft house) & $\$ 50.70$ & $\$ 21,963,240$ \\
\hline Sidewalk (1.5m wide) & $\$ 150$ & per $m$ & $\$ 103,037$ & $\begin{array}{l}\text { Soft Costs for Mixed Use (of Hard } \\
\text { costs) }\end{array}$ & $30 \%$ & $\$ 10,845,394.56$ \\
\hline Buffer Zone (10ft wide) & $\$ 89$ & per $\mathrm{m}$ & $\$ 61,135$ & TOWNHOUSE DCs & & \\
\hline Street Lighting + Hydro & $\$ 280$ & per metre & $\$ 192,335$ & Town of Whitby DC & $\$ 9,479$ & \\
\hline Tree Planting (0.8 per lot) & $\$ 400$ & 0.8 & $\$ 92,416$ & Region of Durham DC & $\$ 20,749$ & \\
\hline Housing Materials/Labor Cost -Townhouse & $\$ 98$ & $/ \mathrm{sqft}$ & $\$ 42,453,600$ & Educational DC & $\$ 2,735$ & \\
\hline Hook Up Costs & $\$ 3,864$ & per lot & $\$ 1,115,923$ & DC Total Per Townhouse & $\$ 32,963$ & $\$ 9,519,714$ \\
\hline $\begin{array}{l}\text { Mixed Use Building Materials/Labor } \\
\text { (Multiplied by GLA) }\end{array}$ & $\$ 195$ & per sqft & $\$ 36,151,315$ & CONDO DCs (1 bedroom) & & \\
\hline SUBTRACT the following reduction: & & & & Town of Whitby DC & $\$ 4,503$ & \\
\hline *VTPI, 2013 (\$25,000 per parking spot) & & & & Region of Durham DC & $\$ 9,746$ & \\
\hline Per Dwelling Unit (25\% reduction) & 1.25 & 42 & $\$ 791,285$ & Educational DC & $\$ 2,735$ & \\
\hline $\begin{array}{l}\text { Per Dwelling Unit for Visitors ( } 25 \% \\
\text { reduction) }\end{array}$ & 0.25 & & $\$ 158,257$ & DC Total Per Condo & $\$ 12,481$ & $\$ 722,361.15$ \\
\hline & & & & CONDO DCs ( 2 bedroom) & & \\
\hline & & & & Town of Whitby DC & $\$ 8,063$ & \\
\hline & & & & Region of Durham DC & $\$ 14,991$ & \\
\hline TOTAL HARD COSTS & & & $\begin{array}{l}\$ 80,800,113.63 \\
\end{array}$ & Educational DC & $\$ 2,735$ & \\
\hline & & & & DC Total Per Condo & $\$ 25,789$ & $\$ 1,990,115.30$ \\
\hline & & & & RETAIL DCs & & \\
\hline & & & & Town of Whitby & $\$ 2.82$ & \\
\hline & & & & Region of Durham & $\$ 13.05$ & \\
\hline & & & & \begin{tabular}{|l|l} 
Educational \\
\end{tabular} & & \\
\hline & & & & \begin{tabular}{|l} 
DC Total Per Retail Sqft \\
\end{tabular} & $\$ 15.87$ & $\$ 735,540.22$ \\
\hline & & & & TOTAL SOFT COSTS & & $\$ 45,776,365.64$ \\
\hline
\end{tabular}

FINANCING

\begin{tabular}{|l|l|l|}
\hline Construction Loan Cost & $10 \%$ & $\$ 13,657,648$ \\
\hline
\end{tabular}

\begin{tabular}{|l|l|l|}
\hline Contingency Fund (on hard/soft & $5 \%$ & $\$ 6,328,824$ \\
\hline
\end{tabular}

\begin{tabular}{ll}
\hline costs) \\
\hline GST + PST \\
\hline TST
\end{tabular}

\begin{tabular}{l|l|l|}
\hline Total Costs & $\$ 1,504,014,77$ \\
\hline
\end{tabular}

\begin{tabular}{l|l}
$25 \%$ & $\$ 41,766,741.48$ \\
\hline
\end{tabular}

\begin{tabular}{|l|l|l|}
\hline RATE OF RETURN \\
\hline Revenues - costs (cash flow) & & $\$ 9,408,915$ \\
\hline
\end{tabular}

Cash flow $/$ Ed

\section{LEGEND \\ Incentives}




\begin{tabular}{|c|c|c|c|}
\hline LAND COSTS & & & \\
\hline Land Area (acre) & & 20.0 & \\
\hline Developable Land & & 19.0 & \\
\hline Average Land Cost (per acre) & & $\$ 500,000$ & \\
\hline Land Cost & & $\$ 10,000,000.00$ & \\
\hline BUILT FORM ASSUMPTIONS & & & \\
\hline \begin{tabular}{|l} 
Average Townhouse Size \\
\end{tabular} & 1500 & sqft & \\
\hline \# of Residential Lots (net/acre) & 19 & 289 & \\
\hline & & $\$ 400,000$ & \\
\hline Total expected Revenues & & $\$ 115,520,000$ & \\
\hline Total Linear Metres of Roads & & & \\
\hline \% of Development Townhouse & 0.8 & 15.2 & \\
\hline$\%$ of Development Mixed Use & & & \\
\hline & $\frac{0.2}{40 \%}$ & 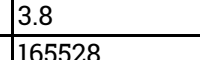 & \\
\hline \begin{tabular}{|l} 
Mixed Use Lot Coverage \\
1 Floor GFA $=$
\end{tabular} & $40 \%$ & $\frac{165528}{66211.2}$ & \begin{tabular}{|l} 
sqft \\
sqft
\end{tabular} \\
\hline \begin{tabular}{|l|l|l} 
Floor GFA $=$ \\
Floors (Above Ground)
\end{tabular} & 4 & 66211.2 & \\
\hline Gross Floor Area & 264845 & sqft & \\
\hline GLA (70\% of GFA) & $70 \%$ & 185391.36 & |sqft \\
\hline 1 Floor GLA $=$ & & 463. & sqft \\
\hline Residential GLA (3 Floors) & 3 & & sqft \\
\hline 1 bedroom (800sqft) & $33 \%$ & 46301.49216 & sqft \\
\hline \# of 1 bedroom units & 800 & 58 & \\
\hline \begin{tabular}{|l} 
Average Sale Price of 800 sqft unit \\
\end{tabular} & & $\$ 319,127$ & \\
\hline Residential Revenues & & $\$ 18,470,051$ & \\
\hline 2 bedroom (1200sqft) & $67 \%$ & 92602.98432 & sqft \\
\hline$\#$ of 2 bedroom units & 1200 & 77 & \\
\hline Average Sale Pric & & $\$ 385,990$ & \\
\hline Residential Revenues & & $\$ 29,786,522$ & \\
\hline Retail GLA (1 Floor) & 1 & 46347.84 & sqft \\
\hline Retail Cost per sqft & $\$ 274$ & $\$ 12,699,308$ & \\
\hline ROAD CALCULATION & & & \\
\hline Roads as \% of subdivision & $20.1 \%$ & & \\
\hline Roads as & & 3.06 & \\
\hline Roads in $\mathrm{m} 2$ (1acre=4046m) & 4047 & 12364.3944 & \\
\hline $\begin{array}{l}\text { Linear metres of Road (Standard of } \\
18 \mathrm{~m} \text { width) }\end{array}$ & 18 & 686.9108 & $\mathrm{~m}$ \\
\hline
\end{tabular}

\begin{tabular}{|c|c|c|c|c|c|c|}
\hline \multicolumn{4}{|l|}{ HARD COSTS } & \multicolumn{3}{|l|}{ SOFT COSTS } \\
\hline Road Construction & $\$ 2,300$ & per $m$ & $\$ 1,579,895$ & Soft Costs For Towns (per sqft house) & $\$ 50.70$ & $\$ 21,963,240$ \\
\hline Sidewalk (1.5m wide) & $\$ 150$ & per $\mathrm{m}$ & $\$ 103,037$ & \begin{tabular}{|l} 
Soft Costs for Mixed Use (of Hard \\
Costs)
\end{tabular} & $30 \%$ & $\$ 11,082,780.14$ \\
\hline Buffer Zone (10ft wide) & $\$ 89$ & per $m$ & $\$ 61,135$ & \multicolumn{3}{|l|}{ TOWNHOUSE DCs (5\% Reduction) } \\
\hline Street Lighting + Hydro & $\$ 280$ & per metre & $\$ 192,335$ & Town of Whitby DC & $\$ \$ 9,479$ & \\
\hline Tree Planting $(0.8$ per lot $)$ & $\$ 400$ & 0.8 & $\$ 92,416$ & \begin{tabular}{|l} 
Region of Durham DC \\
\end{tabular} & $\$ 20,749$ & \\
\hline Housing Materials/Labor Cost -Townhouse & $\$ 98$ & /sqft & $\$ 42,453,600$ & Educational DC & $\$ 2,735$ & \\
\hline Hook Up Costs & $\$ 3,864$ & per lot & $\$ 1,115,923$ & DC Total Per Townhouse & $\$ 32,963$ & $\$ 9,043,729$ \\
\hline $\begin{array}{l}\text { Mixed Use Building Materials/Labor } \\
\text { (Multiplied by GLA) }\end{array}$ & $\$ 195$ & per sqft & $\$ 36,151,315$ & \multicolumn{3}{|c|}{ CONDO DCs (1 bedroom) (5\% Reduction) } \\
\hline SUBTRACT the following reduction: & & & & Town of Whitby DC & $\$ 4,503$ & \\
\hline *VTPI, 2013 (\$25,000 per parking spot) & & & & Region of Durham DC & $\$ 9,746$ & \\
\hline Per Dwelling Unit (25\% reduction) & 1.25 & 42 & $\$ 791,285$ & Educational DC & $\$ 2,735$ & \\
\hline \multirow[t]{4}{*}{$\begin{array}{l}\text { Per Dwelling Unit for Visitors (25\% } \\
\text { reduction) }\end{array}$} & 0.25 & 8 & $\$ 158,257$ & DC Total Per Condo & $\$ 12,481$ & $\$ 686,243.10$ \\
\hline & & & & \multicolumn{3}{|c|}{ CONDO DCs (2 bedroom) (5\% Reduction) } \\
\hline & & & & Town of Whitby DC & $\$ 8,063$ & \\
\hline & & & & Region of Durham DC & $\$ 14,991$ & \\
\hline \multirow[t]{8}{*}{ TOTAL HARD COSTS } & & & $\$ 80,800,113.63$ & Educational DC & $\$ 2,735$ & \\
\hline & & & & DC Total Per Condo & $\$ 25,789$ & $\$ 1,890,609.54$ \\
\hline & & & & RETAIL DCs (5\% Reduction) & & \\
\hline & & & & \begin{tabular}{|l|} 
Town of Whitby \\
\end{tabular} & $\$ 2.82$ & \\
\hline & & & & Region of Durham & $\$ 13.05$ & \\
\hline & & & & Educational & & \\
\hline & & & & DC Total Per Retail Sqft & $\$ 15.87$ & $\$ 698,763.21$ \\
\hline & & & & TOTAL SOFT COSTS & & $\$ 45,365,364.66$ \\
\hline
\end{tabular}

FINANCING \begin{tabular}{|l|l|l|l|l|}
\hline $136,165,478.2$ \\
\hline
\end{tabular} \begin{tabular}{|l|l|l|}
\hline Contingency Fund (on hard/soft & $10 \%$ & $\$ 13,616,548$ \\
\hline $56,308,274$
\end{tabular} costs)

Total Costs \begin{tabular}{|l|l|l|l} 
& $\$ 10,504,014,77$ \\
$\$ 166,594315$
\end{tabular} \begin{tabular}{l|l|l}
$25 \%$ & $\$ 41,648,578.70$ \\
\hline
\end{tabular} \begin{tabular}{|l|l|l|l|}
\hline RATE OF RETURN \\
\hline Revenues - costs (cash flow) & & $\$ 9,881,566$ \\
\hline
\end{tabular} Cash flow / Equity (ROE) $9,881,566$

\section{LEGEND}

Incentives 
APPENDIX 3B - \#2 WIDE SMOOTH FOOTWAYS

\begin{tabular}{|c|c|c|c|c|c|c|c|c|c|c|}
\hline \multicolumn{4}{|l|}{ LAND COSTS } & \multicolumn{4}{|l|}{ HARD COSTS } & \multicolumn{3}{|l|}{ SOFT COSTS } \\
\hline Land Area (acre) & & 20.0 & & \begin{tabular}{|l|} 
Road Construction \\
\end{tabular} & $\$ 2,300$ & per $m$ & $\$ 2,078,809$ & Soft Costs (per sqft of house) & $\$ 50.70$ & $\$ 27,454,050$ \\
\hline Developable Land & & 19.0 & & Sidewalk (2m wide + non-slip) & $\$ 160$ & per $\mathrm{m}$ & $\$ 144,613$ & & & \\
\hline Average Land Cost (per acre) & & $\$ 500,000$ & & Buffer Zone (10ft wide) & $\$ 89$ & per $\mathrm{m}$ & $\$ 80,441$ & Town of Whitby DC & $\$ 9,479$ & \\
\hline Land Cost & & $\$ 10,000,000.00$ & & Street Lighting + Hydro & $\$ 280$ & per $m$ & $\$ 253,072$ & Region of Durham DC & $\$ 20,749$ & \\
\hline \multicolumn{4}{|l|}{ BUILT FORM ASSUMPTIONS } & Tree Planting ( 0.8 per lot $)$ & $\$ 400$ & 0.8 & $\$ 115,520$ & Educational DC & $\$ 2,735$ & \\
\hline Average Townhouse Size & 1500 & sqft & & Housing Materials/Labor Cost & $\$ 98$ & /sqft & $\$ 53,067,000$ & \begin{tabular}{|l} 
Development Charges Total \\
\end{tabular} & $\$ 32,963$ & $\$ 11,899,643$ \\
\hline \# of Residential Lots (net/acre) & 19 & 361 & & Hook Up Costs & $\$ 3,864$ & per lot & $\$ 1,394,904$ & & & \\
\hline Average Price of Home & & $\$ 400,000$ & & & & & & & & \\
\hline Total expected Revenues & & $\$ 144,400,000$ & & & & & & & & \\
\hline Total Linear Metres of Roads & & 904 & & & & & & & & \\
\hline \multicolumn{11}{|l|}{ ROAD CALCULATION } \\
\hline Roads as $\%$ of subdivision ${ }^{*}$ & $20.1 \%$ & & & & & & & & & \\
\hline Roads as acres & & 4.02 & acres & & & & & & & \\
\hline Roads in m2 (1acre $=4046 \mathrm{~m})$ & 4047 & 16268.94 & $\mathrm{~m}^{2}$ & & & & & & & \\
\hline $\begin{array}{l}\text { Linear metres of Road (Standard of } \\
18 \mathrm{~m} \text { width) }\end{array}$ & & 903.83 & $\mathrm{~m}$ & TOTAL HARD COSTS & & & $\$ 57,134,359$ & TOTAL SOFT COSTS & & $\$ 39,353,693$ \\
\hline
\end{tabular}

FINANCING

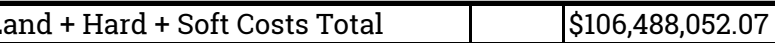
\begin{tabular}{l|l|l} 
Construction Loan Cost & $10 \%$ & $\$ 10,648,805$ \\
\hline
\end{tabular} \begin{tabular}{|l|l|l}
\hline ontingency Fund (on hard/soft & $5 \%$ & $\$ 4,824,403$
\end{tabular} 
APPENDIX 4B -\#3 FREQUENT CROSSINGS

\begin{tabular}{|c|c|c|c|}
\hline \multicolumn{4}{|l|}{ LAND COSTS } \\
\hline \begin{tabular}{|l} 
Land Area (acre) \\
\end{tabular} & & 20.0 & \\
\hline Developable Land & & 19.0 & \\
\hline Average Land Cost (per acre) & & $\$ 500,000$ & \\
\hline Land Cost & & $\$ 10,000,000.00$ & \\
\hline \multicolumn{4}{|l|}{ BUILT FORM ASSUMPTIONS } \\
\hline Average Townhouse Size & 1500 & sqft & \\
\hline \# of Residential Lots (net/acre) & 19 & 361 & \\
\hline Average Price of Home & & $\$ 400,000$ & \\
\hline Total expected Revenues & & $\$ 144,400,000$ & \\
\hline Total Linear Metres of Roads & & 904 & \\
\hline \multicolumn{4}{|l|}{ ROAD CALCULATION } \\
\hline Roads as $\%$ of subdivision ${ }^{*}$ & $20 \%$ & & \\
\hline Roads as acres & & 4.02 & acres \\
\hline Roads in m2 (lacre $=4046 \mathrm{~m})$ & 4047 & 16268.94 & $\mathrm{~m}^{2}$ \\
\hline \begin{tabular}{|l|} 
Linear metres of Road \\
(Standard of $18 \mathrm{~m}$ width)
\end{tabular} & 18 & 903.83 & $\mathrm{~m}$ \\
\hline
\end{tabular}

\begin{tabular}{|l|l|l|l|}
\hline HARD COSTS & \multicolumn{3}{|l|}{} \\
\hline Road Construction & $\$ 2,300$ & per m & $\$ 2,078,809$ \\
\hline Sidewalk (1.5m wide) & $\$ 150$ & per m & $\$ 135,575$ \\
\hline Buffer Zone (10ft wide) & $\$ 89$ & per m & $\$ 80,441$ \\
\hline Street Lighting + Hydro & $\$ 280$ & per m & $\$ 253,072$ \\
\hline Tree Planting (0.8 per lot) & $\$ 400$ & 0.8 & $\$ 115,520$ \\
\hline Housing Materials/Labor Cost & $\$ 98$ & $/$ sqft & $\$ 53,067,000$ \\
\hline Hook Up Costs & $\$ 3,864$ & per lot & $\$ 1,394,904$ \\
\hline Crossings & & \# of intersections \\
\hline $\begin{array}{l}\text { Internal Crossing (Pedestrian Crossing + } \\
\text { Striped) }\end{array}$ & $\$ 10,661.44$ & 1 & $\$ 10,661$ \\
\hline $\begin{array}{l}\text { Internal Crossing (High Visibility } \\
\text { Crossing) }\end{array}$ & $\$ 15,975$ & 1 & $\$ 15,975$ \\
\hline External Crossings with APS (3 Total) & $\$ 10,000$ & 3 & $\$ 30,000$ \\
\hline
\end{tabular}

\begin{tabular}{|l|l|l|}
\hline SOFT COSTS & & \\
\hline Soft Costs (per sqft of house) & $\$ 50.70$ & $\$ 27,454,050$ \\
\hline & & \\
\hline Town of Whitby DC & $\$ 9,479$ & \\
\hline Region of Durham DC & $\$ 20,749$ & \\
\hline Educational DC & $\$ 2,735$ & \\
\hline Development Charges Total & $\$ 32,963$ & $\$ 11,899,643$ \\
\hline
\end{tabular}

FINANCING

\begin{tabular}{|l|l|l|l|l|}
\hline Land + Hard + Soft Costs Total & $\$ 106,535,650.21$ \\
\hline Cons
\end{tabular}

\begin{tabular}{|l|l|l|l|l|l|l}
\hline Construction Loan Cost & $10 \%$ & $\$ 10,653,565$ \\
\hline
\end{tabular}

\begin{tabular}{l|l|l} 
Contingency Fund (on hard/soft & $5 \%$ & $\$ 4,826,783$ \\
\hline
\end{tabular}

\begin{tabular}{|l|l|l|}
\hline costs) & $5 \%$ & $\$ 4,826,783$ \\
\hline GST + PST & & $\$ 7,433,654.44$ \\
\hline
\end{tabular}

Total Costs

\begin{tabular}{l} 
Equity \\
\hline RATE OF RETURN \\
\hline Revenues - COSts (cash
\end{tabular}

RATE OF RETURN \begin{tabular}{l|l|l|} 
& $\$ 129,449,652$ \\
\hline $25 \%$ & $\$ 32,362,413.04$ \\
\hline
\end{tabular}

Revenues - costs (cash flow)

$33,362,413.04$

Cash flow / Equity (ROE)

$46.1966 \%$

*It is assumed that the Town or Region with Cover the cost of the Signalized intersection itself at $\$ 150,000$ each

\begin{tabular}{|lll|l|}
\hline TOTAL HARD COSTS & $\$ 57,181,957.21$ & TOTAL SOFT COSTS & $\$ 39,353,693.00$ \\
\hline
\end{tabular}


APPENDIX 5B - \#4 CLEAR SIGNS

\begin{tabular}{|c|c|c|c|c|c|c|c|c|c|c|}
\hline \multicolumn{4}{|l|}{ LAND COSTS } & \multicolumn{4}{|l|}{ HARD COSTS } & \multicolumn{3}{|l|}{ SOFT COSTS } \\
\hline Land Area (acre) & & 20.0 & & Road Construction & $\$ 2,300$ & per $m$ & $\$ 2,078,809$ & Soft Costs (per sqft of house) & $\$ 50.70$ & $\$ 27,454,050$ \\
\hline Developable Land & & 19.0 & & Sidewalk (1.5m wide) & $\$ 150$ & per $m$ & $\$ 135,575$ & & & \\
\hline Average Land Cost (per acre) & & $\$ 500,000$ & & Buffer Zone (10ft wide) & $\$ 89$ & per $\mathrm{m}$ & $\$ 80,441$ & Town of Whitby DC & $\$ 9,479$ & \\
\hline Land Cost & & $\$ 10,000,000.00$ & & Street Lighting + Hydro & $\$ 280$ & per $\mathrm{m}$ & $\$ 253,072$ & Region of Durham DC & $\$ 20,749$ & \\
\hline \multicolumn{4}{|l|}{ BUILT FORM ASSUMPTIONS } & Tree Planting ( 0.8 per lot $)$ & $\$ 400$ & 0.8 & $\$ 115,520$ & Educational DC & $\$ 2,735$ & \\
\hline Average Townhouse Size & 1500 & sqft & & Housing Materials/Labor Cost & $\$ 98$ & $/ \mathrm{sqft}$ & $\$ 53,067,000$ & Development Charges Total & $\$ 32,963$ & $\$ 11,899,643$ \\
\hline \# of Residential Lots (net/acre) & 19 & 361 & & Hook Up Costs & $\$ 3,864$ & per lot & $\$ 1,394,904$ & & & \\
\hline Average Price of Home & & $\$ 400,000$ & & Simple Black and White Signs (29 Total) & $\$ 500$ & each & $\$ 14,500$ & & & \\
\hline Total expected Revenues & & $\$ 144,400,000$ & & & & & & & & \\
\hline Total Linear Metres of Roads & & 904 & & & & & & & & \\
\hline \multicolumn{4}{|l|}{ ROAD CALCULATION } & & & & & & & \\
\hline Roads as \% of subdivision* & $20 \%$ & & & & & & & & & \\
\hline Roads as acres & & 4.02 & acres & & & & & & & \\
\hline \begin{tabular}{|l|l|} 
Roads in $\mathrm{m} 2($ lacre $=4046 \mathrm{~m})$ & 4 \\
\end{tabular} & 4047 & 16268.94 & $\mathrm{~m}^{2}$ & & & & & & & \\
\hline \begin{tabular}{|l|l} 
Linear metres of Road (Standard of \\
$18 \mathrm{~m}$ width)
\end{tabular} & 18 & 903.83 & $\mathrm{~m}$ & TOTAL HARD COSTS & & & $\$ 57,139,820.77$ & TOTAL SOFT COSTS & & $\$ 39,353,693.00$ \\
\hline
\end{tabular}

INANCING

\begin{tabular}{|l|l|l|l|l|}
\hline and + Hard + Soft Costs Total & & $\$ 106,493,513.77$
\end{tabular}

\begin{tabular}{|l|l|l|}
\hline Contingency Fund (on hard/soft & $5 \%$ & $\$ 4,824,676$ \\
\hline
\end{tabular}

\begin{tabular}{|l|l|l}
\hline costs) & $5 \%$ & $\$ 4,824,676$ \\
\hline GST + PST & & $\$ 7,428,176.70$ \\
\hline
\end{tabular}

\begin{tabular}{|l|l|l|l}
\hline Total Costs & $\$ 29,395,718$ \\
\hline
\end{tabular}

$\$ 32,348,929.38$

RATE OF RETURN

Revenues - costs (cash flow)

$\$ 15,004,282$

Cash flow / Equity (ROE)

$46.3826 \%$ 
APPENDIX 6B - \#5 FREQUENT SEATING

\begin{tabular}{|c|c|c|c|}
\hline \multicolumn{4}{|l|}{ LAND COSTS } \\
\hline Land Area (acre) & & 20.0 & \\
\hline Developable Land & & 19.0 & \\
\hline Average Land Cost (per acre) & & $\$ 500,000$ & \\
\hline Land Cost & & $\$ 10,000,000.00$ & \\
\hline \multicolumn{4}{|l|}{ BUILT FORM ASSUMPTIONS } \\
\hline Average Townhouse Size & 1500 & sqft & \\
\hline \# of Residential Lots (net/acre) & 19 & 361 & \\
\hline Average Price of Home & & $\$ 400,000$ & \\
\hline Total expected Revenues & & $\$ 144,400,000$ & \\
\hline Total Linear Metres of Roads & & 904 & \\
\hline \multicolumn{4}{|l|}{ ROAD CALCULATION } \\
\hline Roads as \% of subdivision* & $20 \%$ & & \\
\hline Roads as acres & & 4.02 & acres \\
\hline Roads in m2 (1acre $=4046 \mathrm{~m})$ & 4047 & 16268.94 & $\mathrm{~m}^{2}$ \\
\hline $\begin{array}{l}\text { Linear metres of Road (Standard of } \\
18 \mathrm{~m} \text { width) }\end{array}$ & 18 & 903.83 & $\mathrm{~m}$ \\
\hline
\end{tabular}

HARD COSTS

Road Construction

Buffer Zone (10ft wide)

Street Lighting + Hydro

Tree Planting ( 0.8 per lot)

\begin{tabular}{l} 
Housing Materials/Labor Cost \\
\hline Hook Up Costs \\
\hline
\end{tabular}

Benches (every $125 \mathrm{~m}$ of road)

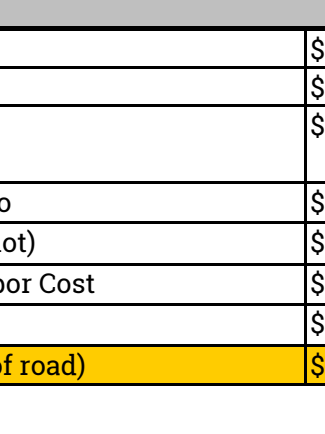

\begin{tabular}{|l|l|l|}
\hline$\$ 2,300$ & per m & $\$ 2,078,809$ \\
\hline$\$ 150$ & per $\mathrm{m}$ & $\$ 135,545$ \\
\hline 89 & per $\mathrm{m}$ & $\$ 80,441$ \\
& & \\
$\$ 280$ & per $\mathrm{m}$ & $\$ 253,072$ \\
$\$ 400$ & 0.8 & $\$ 115,520$ \\
\hline$\$ 98$ & $/$ sqft & $\$ 35,067,000$ \\
\hline$\$ 3,864$ & per lot & $\$ 1,394,904$ \\
\hline$\$ 1,000$ & per bench & $\$ 8,000$ \\
\hline
\end{tabular}

\begin{tabular}{|l|l|l|}
\hline Soft Costs (per sqft of house) & $\$ 50.70$ & $\$ 27,454,050$ \\
\hline
\end{tabular}

Town of Whitby DC

Region of Durham $D C$

\begin{tabular}{|l|l|l|}
\hline Region of Durham DC & $\$ 20,749$ & \\
\hline Educational DC & $\$ 2,735$ & \\
\hline Development Charges Total & $\$ 32,963$ & $\$ 11,899,643$ \\
\hline
\end{tabular}

TOTAL HARD COSTS

$\$ 57,133,320.77$

TOTAL SOFT COSTS

TOTaL Hand costs

Total sof costs

FINANCING

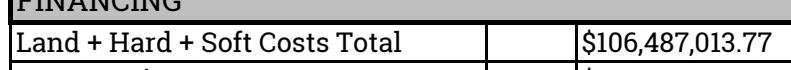

\begin{tabular}{|l|l|l|}
\hline Construction Loan Cost & $10 \%$ & $\$ 10,648,701$ \\
\hline Contingency Fund (on hard/soft & & $\$ 4,824,35$ \\
\hline
\end{tabular}

\begin{tabular}{l|l|l|l}
\hline $\begin{array}{l}\text { Contingency Fund (on hard/soft } \\
\text { costs) }\end{array}$ & $5 \%$ & $\$ 4,824,351$ \\
\hline
\end{tabular}

\begin{tabular}{|l|l|}
\hline costs) & $\$ 4,24,35$ \\
\hline GST + PST & $\$ 7,427,331.70$ \\
\hline
\end{tabular}

\begin{tabular}{|l|l|l|}
\hline Total Costs & & $\$, 429,312,387,798$ \\
\hline
\end{tabular}

\begin{tabular}{l} 
Equity \\
\hline RATE OF RETURN \\
\hline
\end{tabular}

\begin{tabular}{|l|l|l|l}
\hline $25 \%$ & $\$ 32,38,34,8499.38$ \\
\hline
\end{tabular}

Revenues - costs (cash flow)

$\$ 15,012,602$ 
APPENDIX 7B - \#6 SMALL BLOCKS + IRREGULAR GRID

\begin{tabular}{|c|c|c|c|}
\hline \multicolumn{4}{|l|}{ LAND COSTS } \\
\hline Land Area (acre) & & 20.0 & \\
\hline Developable Land & & 19.0 & \\
\hline Average Land Cost (per acre) & & $\$ 500,000$ & \\
\hline Land cost & & $\$ 10,000,000.00$ & \\
\hline \multicolumn{4}{|l|}{ BUILT FORM ASSUMPTIONS } \\
\hline Average Townhouse Size & 1500 & sqft & \\
\hline \# of Residential Lots (net/acre) & 16.8 & 319 & \\
\hline Average Price of Home & & $\$ 400,000$ & \\
\hline Total expected Revenues & & $\$ 127,680,000$ & \\
\hline Total Linear Metres of Roads & & 1329 & \\
\hline \multicolumn{4}{|l|}{ ROAD CALCULATION } \\
\hline Roads as \% of subdivision & $30 \%$ & & \\
\hline Roads as acres & & 5.91 & |acres \\
\hline Roads in m2 (1acre=4046m) & 4047 & 23917.77 & $\mathrm{~m}^{2}$ \\
\hline $\begin{array}{l}\text { Linear metres of Road (Standard of } \\
18 \mathrm{~m} \text { width) }\end{array}$ & 18 & 1328.765 & $\mathrm{~m}$ \\
\hline
\end{tabular}

\section{HARD COSTS}

oad Construction

Sidewalk (1.5m wide)

Street Lighting + Hydro

ree Planting (0.8 per lot)

housing Materials/Labor Cost

Hook Up Costs

TOTAL HARD COSTS

\begin{tabular}{|l|l|l|}
\hline SOFT COSTS \\
\hline Soft Costs (per sqft of house) & $\$ 50.70$ & $\$ 24,275,160$ \\
\hline Town of Whitby DC & & \\
& $\$ 9,479$ & \\
\hline Region of Durham DC & $\$ 20,749$ & \\
\hline Educational DC & $\$ 2,735$ & \\
\hline Development Charges Total & $\$ 32,963$ & $\$ 10,521,790$ \\
\hline
\end{tabular}

\begin{tabular}{|l|l|l|}
\hline Educational DC & $\$ 2,735$ & $\$ 10,521,790$ \\
\hline Development Charges Total & $\$ 32,963$ &
\end{tabular}

\begin{tabular}{l|l|l|l}
$\$ 400$ & 0.8 & $\$ 102,144$ \\
$\$ 98$ & sqt & $\$ 6,922,400$ \\
\hline
\end{tabular}

\begin{tabular}{l|l|l|l}
$\$ 98$ & sqft & $\$ 46,922,400$ \\
$\$ 3,864$ & &
\end{tabular}

(n)

\begin{tabular}{ll} 
RA \\
Rever \\
\hline Cash \\
\hline
\end{tabular}

FINANCING

\begin{tabular}{|l|l|l|l|l|l|l|}
\hline Land + Hard + Soft Costs Total & & $\$ 96,800,670.94$
\end{tabular}

\begin{tabular}{|l|l|l|}
\hline Construction Loan Cost & $10 \%$ & $\$ 9,680,067$ \\
\hline
\end{tabular}

\begin{tabular}{|l|l|l|}
\hline Contingency Fund (on hard/soft & $5 \%$ & $\$ 4,340,034$ \\
\hline
\end{tabular}

\begin{tabular}{|l|l|l|}
\hline costs) & $5 \%$ & $\$ 4,340,034$ \\
\hline GST + PST & & $\$ 6,760,483.7$ \\
\hline
\end{tabular}

RATE OF RETURN

$\$ \$ \$ 117,581,255$

(cash flow)

$25 \% \quad \$ 29,395,313.84$

列

$34.3549 \%$ 
APPENDIX 8B- \#7 MARKED LEVEL CHANGES

\begin{tabular}{|c|c|c|c|c|c|c|c|c|c|c|}
\hline \multicolumn{4}{|l|}{ LAND COSTS } & \multicolumn{4}{|l|}{ HARD COSTS } & \multicolumn{3}{|l|}{ SOFT COSTS } \\
\hline Land Area (acre) & & 20.0 & & \begin{tabular}{|l} 
Road Construction \\
\end{tabular} & $\$ 2,300$ & per $\mathrm{m}$ & $\$ 2,078,809$ & Soft Costs (per sqft of house) & $\$ 50.70$ & $\$ 27,454,050$ \\
\hline Developable Land & & 19.0 & & Sidewalk (1.5m wide) & $\$ 150$ & per $\mathrm{m}$ & $\$ 135,575$ & & & \\
\hline Average Land Cost (per acre) & & $\$ 500,000$ & & Buffer Zone (10ft wide) & $\$ 89$ & per $m$ & $\$ 80,441$ & Town of Whitby DC & $\mid \$ 9,479$ & \\
\hline Land Cost & & $\$ 10,000,000.00$ & & Street Lighting + Hydro & $\$ 280$ & per $\mathrm{m}$ & $\$ 253,072$ & Region of Durham DC & $\$ 20,749$ & \\
\hline \multicolumn{4}{|l|}{ BUILT FORM ASSUMPTIONS } & Tree Planting ( 0.8 per lot $)$ & $\$ 400$ & 0.8 & $\$ 115,520$ & \begin{tabular}{|l|} 
Educational DC \\
\end{tabular} & $\$ 2,735$ & \\
\hline Average Townhouse Size & 1500 & sqft & & Housing Materials/Labor Cost & $\$ 98$ & /sqft & $\$ 53,067,000$ & Development Charges Total & $\$ 32,963$ & $\$ 11,899,643$ \\
\hline \# of Residential Lots (net/acre) & 19 & 361 & & Hook Up Costs & $\$ 3,864$ & per lot & $\$ 1,394,904$ & & & \\
\hline Average Price of Home & & $\$ 400,000$ & & Ramp Installation (2 per corner) & $\$ 46.95$ & per ramp & $\$ 1,878$ & & & \\
\hline Total expected Revenues & & $\$ 144,400,000$ & & & & & & & & \\
\hline Total Linear Metres of Roads & & 904 & & & & & & & & \\
\hline \multicolumn{11}{|l|}{ ROAD CALCULATION } \\
\hline Roads as $\%$ of subdivision* & $20 \%$ & & & & & & & & & \\
\hline Roads as acres & & 4.02 & $\frac{\text { acres }}{2}$ & & & & & & & \\
\hline Roads in m2 (1acre $=4046 \mathrm{~m}$ ) & 4047 & 16268.94 & $\mathrm{~m}^{2}$ & & & & & & & \\
\hline $\begin{array}{l}\text { Linear metres of Road (Standard of } \\
\text { 18m width) }\end{array}$ & 18 & 903.83 & $\mathrm{~m}$ & TOTAL HARD COSTS & & & $\$ 57,127,198.77$ & TOTAL SOFT COSTS & & $\$ 39,353,693.0 \mathrm{C}$ \\
\hline
\end{tabular}

\begin{tabular}{|c|c|c|}
\hline \multicolumn{3}{|l|}{ JANCING } \\
\hline nd + Hard + Soft Costs Total & & $\$ 106,480,891.77$ \\
\hline nstruction Loan Cost & $10 \%$ & $\$ 10,648,089$ \\
\hline $\begin{array}{l}\text { ontingency Fund (on hard/soft } \\
\text { osts) }\end{array}$ & $5 \%$ & $\$ 4,824,045$ \\
\hline ST + PST & & 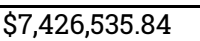 \\
\hline tal Costs & & $\$ 129,379,561$ \\
\hline uity & $25 \%$ & $\$ 32,344,890.34$ \\
\hline ATE OF RETURN & & \\
\hline venues - costs (cash flow) & & $\$ 15,020,439$ \\
\hline sh flow / Equity (ROE) & & $46.4384 \%$ \\
\hline
\end{tabular}

Cash flow / Equity (ROE) 
APPENDIX 9B - \#8 GROUND LEVEL TOILETS

\begin{tabular}{|c|c|c|c|c|c|c|c|c|c|c|}
\hline \multicolumn{4}{|l|}{ LAND COSTS } & \multicolumn{4}{|l|}{ HARD COSTS } & \multicolumn{3}{|l|}{ SOFT COSTS } \\
\hline Land Area (acre) & & 20.0 & & \begin{tabular}{|l} 
Road Construction \\
\end{tabular} & $\$ 2,300$ & per $m$ & $\$ 2,078,809$ & Soft Costs (per sqft of house) & $\$ 50.70$ & $\$ 27,454,050$ \\
\hline \begin{tabular}{|l|} 
Developable Land \\
\end{tabular} & & 19.0 & & \begin{tabular}{|l} 
Sidewalk (1.5m wide) \\
\end{tabular} & $\$ 150$ & per $\mathrm{m}$ & $\$ 135,575$ & & & \\
\hline \begin{tabular}{|l} 
Average Land Cost (per acre) \\
\end{tabular} & & $\$ 500,000$ & & Buffer Zone (10ft wide) & $\$ 89$ & per $\mathrm{m}$ & $\$ 80,441$ & Town of Whitby DC & $\$ 9,479$ & \\
\hline Land Cost & & $\$ 10,000,000.00$ & & Street Lighting + Hydro & $\$ 280$ & per $m$ & $\$ 253,072$ & Region of Durham DC & $\$ 20,749$ & \\
\hline \multicolumn{4}{|l|}{ BUILT FORM ASSUMPTIONS } & Tree Planting (0.8 per lot) & $\$ 400$ & 0.8 & $\$ 115,520$ & Educational DC & $\$ 2,735$ & \\
\hline \begin{tabular}{|l|} 
Average Townhouse Size \\
\end{tabular} & 1500 & sqft & & Housing Materials/Labor Cost & $\$ 98$ & $/$ sqft & $\$ 53,067,000$ & Development Charges Total & $\$ 32,963$ & $\$ 11,899,643$ \\
\hline \# of Residential Lots (net/acre) & 19 & 361 & & Hook Up Costs & $\$ 3,864$ & per lot & $\$ 1,394,904$ & & & \\
\hline Average Price of Home & & $\$ 400,000$ & & Toilet Construction + Hook up & $\$ 450,000$ & & $\$ 450,000$ & & & \\
\hline Total expected Revenues & & $\$ 144,400,000$ & & & & & & & & \\
\hline Total Linear Metres of Roads & & 904 & & & & & & & & \\
\hline \multicolumn{11}{|l|}{ ROAD CALCULATION } \\
\hline Roads as $\%$ of subdivision ${ }^{*}$ & $20 \%$ & & & & & & & & & \\
\hline Roads as acres & & 4.02 & acres & & & & & & & \\
\hline Roads in m2 (lacre $=4046 \mathrm{~m}$ ) & 4047 & 16268.94 & $\mathrm{~m}^{2}$ & & & & & & & \\
\hline $\begin{array}{l}\text { Linear metres of Road (Standard } \\
\text { 18m width) }\end{array}$ & 18 & 903.83 & $\mathrm{~m}$ & TOTAL HARD COSTS & & & $\$ 57,575,320.77$ & TOTAL SOFT COSTS & & $\$ 39,353,693.0$ \\
\hline
\end{tabular}

FINANCING

\begin{tabular}{|l|l|l|l|l|}
\hline and + Hard + Soft Costs Total & & $\$ 106,929,013.77$
\end{tabular}

\begin{tabular}{l|l|l}
\hline Construction Loan Cost & $10 \%$ & $\$ 10,692,901$ \\
\hline
\end{tabular}

\begin{tabular}{|l|l|l|}
\hline Contingency Fund (on hard/soft & $5 \%$ & $\$ 4,846,451$ \\
\hline
\end{tabular}

\begin{tabular}{|l|l|l}
\hline costs) & $5 \%$ & $\$ 4,846,451$ \\
\hline GST + PST & & $\$ 7,484,791.70$ \\
\hline S Cost & & $\$, 29,95,58$ \\
\hline
\end{tabular}

\begin{tabular}{|l|l|l}
\hline Total Costs & $\$ 129,953,158$ \\
\hline
\end{tabular}

\begin{tabular}{|l|l}
\hline Equity & $25 \%$ \\
$\$ 32,488,289.38$
\end{tabular}

Revenues - costs (cash flow)

$\$ 14,446,842$

Cash flow / Equity (ROE)

\begin{tabular}{|l|l|}
\hline & $\$ 14,446,842$ \\
\hline $44.4678 \%$ \\
\hline
\end{tabular} 
APPENDIX 10B - \#9 BUS SHELTERS

\begin{tabular}{|c|c|c|c|c|c|c|c|c|c|c|}
\hline \multicolumn{4}{|l|}{ LAND COSTS } & \multicolumn{4}{|l|}{ HARD COSTS } & \multicolumn{3}{|l|}{ SOFT COSTS } \\
\hline Land Area (acre) & & 20.0 & & Road Construction & $\$ 2,300$ & per $m$ & $\$ 2,078,809$ & Soft Costs (per sqft of house) & $\$ 50.70$ & $\$ 27,454,050$ \\
\hline Developable Land & & 19.0 & & Sidewalk (1.5m wide) & $\$ 150$ & per $\mathrm{m}$ & $\$ 135,575$ & & & \\
\hline Average Land Cost (per acre) & & $\$ 500,000$ & & Buffer Zone (10ft wide) & $\$ 89$ & per $\mathrm{m}$ & $\$ 80,441$ & Town of Whitby DC & $\$ 9,479$ & \\
\hline Land Cost & & $\$ 10,000,000.00$ & & Street Lighting + Hydro & $\$ 280$ & per $m$ & $\$ 253,072$ & Region of Durham DC & $\$ 20,749$ & \\
\hline \multicolumn{4}{|l|}{ BUILT FORM ASSUMPTIONS } & Tree Planting ( 0.8 per lot $)$ & $\$ 400$ & 0.8 & $\$ 115,520$ & \begin{tabular}{|l} 
Educational DC \\
\end{tabular} & $\$ 2,735$ & \\
\hline Average Townhouse Size & 1500 & sqft & & Housing Materials/Labor Cost & $\$ 98$ & /sqft & $\$ 53,067,000$ & \begin{tabular}{|l} 
Development Charges Total \\
\end{tabular} & $\$ 32,963$ & $\$ 11,899,643$ \\
\hline \# of Residential Lots (net/acre) & 19 & 361 & & Hook Up Costs & $\$ 3,864$ & per lot & $\$ 1,394,904$ & & & \\
\hline \begin{tabular}{|l} 
Average Price of Home \\
\end{tabular} & & $\$ \$ \$ 400,000$ & & Enclosed Bus Shelter (each) & $\$ 8,000$ & 1 & $\$ \$ \$, 000$ & & & \\
\hline \begin{tabular}{|l|l} 
Total expected Revenues \\
\end{tabular} & & $\$ 144,400,000$ & & & & & & & & \\
\hline \begin{tabular}{|l} 
Total Linear Metres of Roads \\
\end{tabular} & & 904 & & & & & & & & \\
\hline \multicolumn{11}{|l|}{ ROAD CALCULATION } \\
\hline Roads as $\%$ of subdivision $*$ & $20 \%$ & & & & & & & & & \\
\hline Roads as acres & & 4.02 & acres & & & & & & & \\
\hline Roads in m2 (1acre $=4046 \mathrm{~m}$ ) & 4047 & 16268.94 & $\mathrm{~m}^{2}$ & & & & & & & \\
\hline \begin{tabular}{|l} 
Linear metres of Road (Standard of \\
$18 \mathrm{~m}$ width)
\end{tabular} & & 903.83 & $\mathrm{~m}$ & TOTAL HARD COSTS & & & $\$ 57,133,320.77$ & TOTAL SOFT COSTS & & $\$ 39,353,693$ \\
\hline
\end{tabular}

INANCING

\begin{tabular}{|l|l|l|l|l|}
\hline and + Hard + Soft Costs Total & & $\$ 106,487,013.77$
\end{tabular}

\begin{tabular}{l|l|l}
\hline Construction Loan Cost & $10 \%$ & $\$ 10,648,701$ \\
\hline
\end{tabular}

\begin{tabular}{|l|l|l|}
\hline Contingency Fund (on hard/soft & $5 \%$ & $\$ 4,824,351$ \\
\hline
\end{tabular}

\begin{tabular}{|l|l|l}
\hline costs) & $5 \%$ & $\$ 4,824,361$ \\
\hline GST + PST & & $\$ 7,427,331.70$ \\
\hline S Cost & & $\$, 29,387,398$ \\
\hline
\end{tabular}

\begin{tabular}{|l|l|l|}
\hline Total Costs & & $\$ 129,387,398$ \\
\hline Equity & $25 \%$ & $\$ 32,346,849.38$ \\
\hline
\end{tabular}

Equity

\begin{tabular}{|l|l|l|l|l|l|l} 
& $\$ 15,602$ \\
\hline Revenues - costs (cash flow) & & $\$ 1,413 \%$
\end{tabular}

Cash flow / Equity (ROE)

$46.4113 \%$ 
APPENDIX 11B - \#10 VARIED URBAN FORM + ARCHITECTURE

\begin{tabular}{|c|c|c|c|c|c|c|c|c|c|c|}
\hline \multicolumn{4}{|l|}{ LAND COSTS } & \multicolumn{4}{|l|}{ HARD COSTS } & \multicolumn{3}{|l|}{ SOFT COSTS } \\
\hline Land Area (acre) & & 20.0 & & \begin{tabular}{|l|} 
Road Construction \\
\end{tabular} & $\$ 2,300$ & per $m$ & $\$ 2,078,809$ & Soft Costs (per sqft of house) & $\$ 50.70$ & $\$ 27,454,050$ \\
\hline Developable Land & & 19.0 & & Sidewalk (1.5m wide) & $\$ \$ \$ 150$ & per $\mathrm{m}$ & $\$ 135,575$ & & & \\
\hline Average Land Cost (per acre) & & $\$ 500,000$ & & Buffer Zone (10ft wide) & $\$ 89$ & per $\mathrm{m}$ & $\$ 80,441$ & Town of Whitby DC & $\$ 9,479$ & \\
\hline Land Cost & & $\$ 10,000,000.00$ & & Street Lighting + Hydro & $\$ 280$ & per $\mathrm{m}$ & $\$ 253,072$ & Region of Durham DC & $\$ 20,749$ & \\
\hline \multicolumn{4}{|l|}{ BUILT FORM ASSUMPTIONS } & \begin{tabular}{|l} 
Tree Planting ( 0.8 per lot $)$ \\
\end{tabular} & $\$ 400$ & 0.8 & $\$ 115,520$ & \begin{tabular}{|l|} 
Educational DC \\
\end{tabular} & $\$ 2,735$ & \\
\hline Average Townhouse Size & 1500 & sqft & & Housing Materials/Labor Cost & $\$ 98$ & /sqft & $\$ 53,067,000$ & Development Charges Total & $\$ 32,963$ & $\$ 11,899,643$ \\
\hline \#\# of Residential Lots (net/acre) & 19 & 361 & & Hook Up Costs & $\$ 3,864$ & per lot & $\$ 1,394,904$ & & & \\
\hline Average Price of Home & & $\$ 400,000$ & & & & & & $\begin{array}{l}\text { New Architectural Design Per } \\
\text { Style }\end{array}$ & $\$ 3,000$ & \\
\hline Total expected Revenues & & $\$ 144,400,000$ & & & & & & $\begin{array}{l}\text { New Architectural Design Per } \\
\text { Model }\end{array}$ & $\$ 1,125$ & \\
\hline Total Linear Metres of Roads & & 904 & & & & & & Number of Styles Per Street & 2 & \\
\hline & & & & & Number of Models Per Street & 2 & \\
\hline & & & & & & & & \begin{tabular}{|l}
$\begin{array}{l}\text { Multiplied by the \# of streets } \\
\text { (minus 1) }\end{array}$ \\
\end{tabular} & 2 & $\$ 16,500$ \\
\hline Roads as $\%$ of subdivision* & $20 \%$ & & & & & & & & & \\
\hline Roads as acres & & 4.02 & acres & & & & & & & \\
\hline Roads in $\mathrm{m} 2$ (1acre $=4046 \mathrm{~m})$ & 4047 & 16268.94 & $\mathrm{~m}^{2}$ & & & & & & & \\
\hline \begin{tabular}{|l} 
Linear metres of Road (Standard of \\
$18 \mathrm{~m}$ width)
\end{tabular} & & 903.83 & $\mathrm{~m}$ & TOTAL HARD COSTS & & & $\$ 57,125,320.77$ & TOTAL SOFT COSTS & & $\$ 39,370,193.00$ \\
\hline
\end{tabular}

\begin{tabular}{|l|l|l|}
\hline FINANCING \\
\hline Land + Hard + Soft Costs Total & & $\$ 106,495,513.77$ \\
\hline Construction Loan Cost & $10 \%$ & $\$ 10,649,551$ \\
\hline $\begin{array}{l}\text { Contingency Fund (on hard/soft } \\
\text { costs) }\end{array}$ & $5 \%$ & $\$ 4,824,776$ \\
\hline GST + PST & & $\$ 7,426,291.70$ \\
\hline Total Costs & & $\$ 129,396,133$ \\
\hline Equity & $25 \%$ & $\$ 32,349,033.13$ \\
\hline RATE OF RETURN & & $\$ 15,003,867$ \\
\hline Revenues - costs (cash flow) & & \\
\hline Cash flow / Equity (ROE) & & $46.3812 \%$ \\
\hline
\end{tabular}

$18 \mathrm{~m}$ wid 
APPENDIX 12B - H11 BUFFER ZONES

\begin{tabular}{|c|c|c|c|}
\hline \multicolumn{4}{|l|}{ LAND COSTS } \\
\hline Land Area (acre) & & 20.0 & \\
\hline Developable Land & & 19.0 & \\
\hline Average Land Cost (per acre) & & $\$ 500,000$ & \\
\hline Land cost & & $\$ 10,000,000.00$ & \\
\hline \multicolumn{4}{|l|}{ BUILT FORM ASSUMPTIONS } \\
\hline $\mid$\begin{tabular}{|l} 
Average Townhouse Size \\
\end{tabular} & 1500 & sqft & \\
\hline \# of Residential Lots (net/acre) & 19 & 361 & \\
\hline Average Price of Home & & $\$ 400,000$ & \\
\hline Total expected Revenues & & $\$ 144,400,000$ & \\
\hline Total Linear Metres of Roads & & 904 & \\
\hline \multicolumn{4}{|l|}{ ROAD CALCULATION } \\
\hline Roads as $\%$ of subdivision ${ }^{*}$ & $20 \%$ & & \\
\hline Roads as acres & & 4.02 & acres \\
\hline Roads in m2 (1acre=4046m) & 4047 & 16268.94 & $\mathrm{~m}^{2}$ \\
\hline $\begin{array}{l}\text { Linear metres of Road (Standard of } \\
18 \mathrm{~m} \text { width) }\end{array}$ & 18 & 903.83 & $\mathrm{~m}$ \\
\hline
\end{tabular}

Linear metres
$18 \mathrm{~m}$ width)

$\mathrm{m}$
HARD COSTS

\begin{tabular}{|l|l|l|l}
\hline oad Construction & $\$ 2,300$ & per $\mathrm{m}$ & $\$ 2,078,809$
\end{tabular}

idewalk (1.5m wide)

Street Lighting + Hydro

ree Planting (0.8 per lot)

Housing Materials/Labor Cost

Hook Up Costs

\begin{tabular}{l|l|l|l|l}
$\$ 400$ & 0.8 & $\$ 115,520$ \\
\hline 598 & $154 t$ & $\$ 25,067,000$ \\
\hline
\end{tabular}

\begin{tabular}{l|l|l|l}
$\$ 98$ & /sqft & $\$ 53,067,000$ \\
$\$ \$ 3,864$ & per & & \\
\hline
\end{tabular}

\begin{tabular}{|l|l|l|}
\hline SOFT COSTS \\
\hline Soft Costs (per sqft of house) & $\$ 50,70$ & $\$ 27,454,050$ \\
\hline & & \\
\hline Town of Whitby DC & $\$ 9,479$ & \\
\hline Region of Durham DC & $\$ 20,749$ & \\
\hline Educational DC & $\$ 2,735$ & \\
\hline Development Charges Total & $\$ 32,963$ & $\$ 11,899,643$ \\
\hline
\end{tabular}

RAT

FINANCING

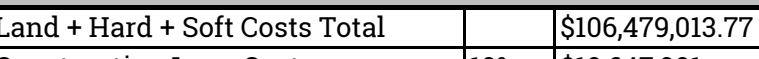

\begin{tabular}{l|l|l|}
\hline Construction Loan Cost & $10 \%$ & $\$ 10,647,901$ \\
\hline
\end{tabular}

\begin{tabular}{|l|l|l|}
\hline Contingency Fund (on hard/soft & $5 \%$ & $\$ 4,823,951$ \\
\hline
\end{tabular}

\begin{tabular}{ll} 
costs) \\
\hline GST + PST
\end{tabular}

\begin{tabular}{|l|l|l|l|l} 
& $\$ 7,426,291.70$ \\
\hline Total Costs & & $\$ 129,377,158$ \\
\hline
\end{tabular}

\begin{tabular}{|l|l|l|}
\hline Total Costs & & $\$ 129,377,158$ \\
\hline Equity & $25 \%$ & $\$ 32,344,289.38$ \\
\hline RATE OF RETURN & \\
\hline RATes & \\
\hline
\end{tabular}

$25 \%-332,344,289.38$

Cash flow / Equity (ROE)

$45.4467 \%$

\begin{tabular}{|llll}
\hline TOTAL HARD COSTS & $\$ 57,125,320.77$ & $\$ 39,353,693.00$ \\
\hline
\end{tabular}


APPENDIX 13B - \#12 LANDMARKS + PLACES OF ACTIVITY

\begin{tabular}{|c|c|c|c|}
\hline \multicolumn{4}{|l|}{ LAND COSTS } \\
\hline Land Area (acre) & & 20.0 & \\
\hline Developable Land & & 19.0 & \\
\hline Average Land Cost (per acre) & & $\$ 500,000$ & \\
\hline Land Cost & & $\$ 10,000,000.00$ & \\
\hline \multicolumn{4}{|l|}{ BUILT FORM ASSUMPTIONS } \\
\hline Average Townhouse Size & 1500 & sqft & \\
\hline \# of Residential Lots (net/acre) & 19 & 361 & \\
\hline Average Price of Home & & $\$ 400,000$ & \\
\hline Total expected Revenues & & $\$ 144,400,000$ & \\
\hline Total Linear Metres of Roads & & 904 & \\
\hline \multicolumn{4}{|l|}{ ROAD CALCULATION } \\
\hline Roads as \% of subdivision* & $20 \%$ & & \\
\hline Roads as acres & & 4.02 & acres \\
\hline Roads in $\mathrm{m} 2$ (1acre $=4046 \mathrm{~m}$ ) & 4047 & 16268.94 & $\mathrm{~m}^{2}$ \\
\hline $\begin{array}{l}\text { Linear metres of Road (Standard c } \\
18 \mathrm{~m} \text { width) }\end{array}$ & 18 & 903.83 & $\mathrm{~m}$ \\
\hline
\end{tabular}

Linear metres
$18 \mathrm{~m}$ width) ad Construction

Buffer Zone (10ft wide)

Street Lighting + Hydro

Tree Planting ( 0.8 per lot)

Housing Materials/Labor cost

\begin{tabular}{l}
\hline Hook Up Costs \\
\hline Community Post Box Pavillion \\
\hline
\end{tabular}

TOTAL HARD COSTS

\begin{tabular}{|l|l|l|}
\hline SOFT COSTS \\
\hline Soft Costs (per sqft of house) & $\$ 50,70$ & $\$ 27,454,050$ \\
\hline & & \\
\hline Town of Whitby DC & $\$ 9,479$ & \\
\hline Region of Durham DC & $\$ 20,749$ & \\
\hline Educational DC & $\$ 2,735$ & \\
\hline Development Charges Total & $\$ 32,963$ & $\$ 11,899,643$ \\
\hline
\end{tabular}

\begin{tabular}{|l|l|l|}
\hline Educational DC & $\$ 2,735$ & $\$ 11,899,643$ \\
\hline Development Charges Total & $\$ 32,963$ &
\end{tabular}

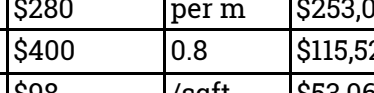

\begin{tabular}{|l|l|l|}
$\$ 988$ & /sqft & $\$ 53,067,000$ \\
$\$ \$ 3,864$ & pert & $\$ 1304,904$ \\
\hline
\end{tabular}

\begin{tabular}{l|l|l|l}
$\$ \$ 3,864$ & per lot & $\$ 1,394,904$ \\
\hline$\$ 22000$ & & $\$ 2,000$ \\
\hline
\end{tabular}

$\$ 22,000$
$\$ 57,147,320.77$
TOTAL SOFT COSTS
FINANCING

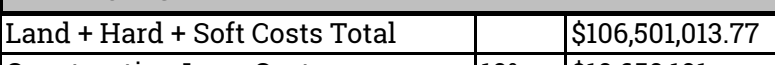

\begin{tabular}{l|l|l|}
\hline Construction Loan Cost & $10 \%$ & $\$ 10,650,101$ \\
\hline
\end{tabular}

\begin{tabular}{|l|l|l|}
\hline Contingency Fund (on hard/soft & $5 \%$ & $\$ 4,825,051$ \\
\hline
\end{tabular}

\begin{tabular}{|l|l|l|}
\hline costs) & $5 \%$ & $\$ 4,825,051$ \\
\hline GST + PST & & $\$ 7,429,151.70$ \\
\hline
\end{tabular}

\begin{tabular}{|l|l|l|}
\hline Total Costs & & $\$ 129,405,318$ \\
\hline & $25 \%$ & $\$ 32,351,329.38$ \\
\hline
\end{tabular}

Equity

\begin{tabular}{|l|l|l|l|l}
\hline Revenues - costs (cash flow) & & $\$ 14,994,682$ \\
\hline
\end{tabular}

Cash flow / Equity (ROE) 
APPENDIX 14B - \#14 DISTINCTIVE FEATURES AT JUNCTIONS

\begin{tabular}{|c|c|c|c|c|c|c|c|c|c|c|}
\hline \multicolumn{4}{|l|}{ LAND COSTS } & \multicolumn{4}{|l|}{ HARD COSTS } & \multicolumn{3}{|l|}{ SOFT COSTS } \\
\hline Land Area (acre) & & 20.0 & & Road Construction & $\$ 2,300$ & per $\mathrm{m}$ & $\$ 2,078,809$ & Soft Costs (per sqft of house) & $\$ 50.70$ & $\$ 27,454,050$ \\
\hline Developable Land & & 19.0 & & Sidewalk (1.5m wide) & $\$ 150$ & per $m$ & $\$ 135,575$ & & & \\
\hline Average Land Cost (per acre) & & $\$ 500,000$ & & Buffer Zone (10ft wide) & $\$ 89$ & per $m$ & $\$ 80,441$ & Town of Whitby DC & |\$9,479 & \\
\hline Land Cost & & $\$ 10,000,000.00$ & & Street Lighting + Hydro & $\$ 280$ & per $m$ & $\$ 253,072$ & Region of Durham DC & $\$ 20,749$ & \\
\hline \multicolumn{4}{|l|}{ BUILT FORM ASSUMPTIONS } & Tree Planting ( 0.8 per lot) & $\$ 400$ & 0.8 & $\$ 115,520$ & \begin{tabular}{|l|} 
Educational DC \\
\end{tabular} & $\$ 2,735$ & \\
\hline \begin{tabular}{|l} 
Average Townhouse Size \\
\end{tabular} & 1500 & sqft & & Housing Materials/Labor Cost & $\$ 98$ & /sqft & $\$ 53,067,000$ & Development Charges Total & $\$ 32,963$ & $\$ 11,899,643$ \\
\hline \# of Residential Lots (net/acre) & 19 & 361 & & Hook Up Costs & $\$ 3,864$ & per lot & $\$ 1,394,904$ & & & \\
\hline Average Price of Home & & $\$ 400,000$ & & $\begin{array}{l}\begin{array}{l}\text { Flower Pots with Plantings ( }(\mathrm{ft} x 3 \mathrm{ft}) \\
\text { internal intersection }\end{array} \\
\end{array}$ & $\$ 1,500$ & 2 & $\$ 6,000.00$ & & & \\
\hline Total expected Revenues & & $\$ 144,400,000$ & & $\begin{array}{l}\text { Landscaped Median (3m x 3m) } 1 \text { per external } \\
\text { intersection }\end{array}$ & $\$ 375.00$ & 3 & $\$ 3,375.00$ & & & \\
\hline Total Linear Metres of Roads & & 904 & & Trellis & $\$ 15,000$ & 1 & $\$ 15,000$ & & & \\
\hline \multicolumn{4}{|l|}{ ROAD CALCULATION } & & & & & & & \\
\hline Roads as $\%$ of subdivision ${ }^{*}$ & $20 \%$ & & & & & & & & & \\
\hline Roads as acres & & 4.02 & acres & & & & & & & \\
\hline \begin{tabular}{|l|l} 
Roads in m2 (1acre $=4046 \mathrm{~m})$ & \multicolumn{1}{c}{} \\
\end{tabular} & 4047 & 16268.94 & $\mathrm{~m}^{2}$ & TOTAL HARD COSTS & & & $\$ 57,149,695.77$ & TOTAL SOFT COSTS & & $\$ 39,353,693.00$ \\
\hline \begin{tabular}{|l|}
$\begin{array}{l}\text { Linear metres of Road (Standard of } \\
18 \mathrm{~m} \text { width) }\end{array}$ \\
$\mid$
\end{tabular} & & 903.83 & $\mathrm{~m}$ & & & & & & & \\
\hline
\end{tabular}

IINANCING

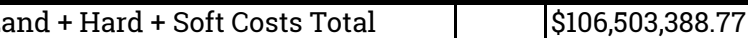

\begin{tabular}{|l|l|l|l|}
\hline Construction Loan Cost & $10 \%$ & $\$ 10,650,339$ \\
\hline
\end{tabular}

\begin{tabular}{|l|l|l|}
\hline Contingency Fund (on hard/soft & $5 \%$ & $\$ 4,825,169$ \\
\hline
\end{tabular}

costs)

otal Costs

Equity

$\$ 4,825,169$
$\$ 7,429,460.4$

RATE OF RETURN

$\$ 129,408,358$

Revenues - costs (cash flow)

Cash flow / Equity (ROE)

$46.3390 \%$

$18 \mathrm{~m}$ width) 


\begin{tabular}{|c|c|c|c|}
\hline \multicolumn{4}{|l|}{ LAND COSTS } \\
\hline Land Area (acre) & & 20.0 & \\
\hline Developable Land & & 19.0 & \\
\hline Average Land Cost (per acre) & & $\$ 500,000$ & \\
\hline Land Cost & & $\$ 10,000,000.00$ & \\
\hline \multicolumn{4}{|l|}{ BUILT FORM ASSUMPTIONS } \\
\hline \begin{tabular}{|l|} 
Average Townhouse Size \\
\end{tabular} & 1500 & sqft & \\
\hline \# of Residential Lots (net/acre) & 16.8 & 319 & \\
\hline Average Price of Home & & $\$ 400,000$ & \\
\hline Total expected Revenues & & $\$ 127,680,000$ & \\
\hline Total Linear Metres of Roads & & 1329 & \\
\hline \multicolumn{4}{|l|}{ ROAD CALCULATION } \\
\hline Roads as \% of subdivision* & $30 \%$ & & \\
\hline Roads as acres & & 5.91 & acre \\
\hline Roads in $\mathrm{m} 2$ (1acre $=4046 \mathrm{~m})$ & 4047 & 23917.77 & $\mathrm{~m}^{2}$ \\
\hline $\begin{array}{l}\text { Linear metres of Road (Standard of } \\
18 \mathrm{~m} \text { width) }\end{array}$ & 18 & 1328.765 & $\mathrm{~m}$ \\
\hline
\end{tabular}

$18 \mathrm{~m}$ width)

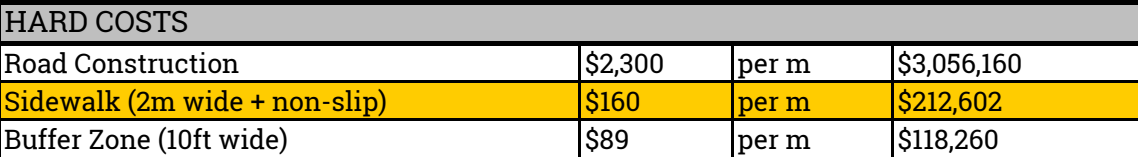

\begin{tabular}{|l|l|l|l}
\hline Sidewalk (2m wide + non-slip) & $\$ 160$ & per $\mathrm{m}$ & $\$ 212,602$ \\
\hline Buffer Zone (10ft wide) & & &
\end{tabular}

Street Lighting + Hydro

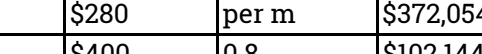

\begin{tabular}{|l|l|l|l}
\hline Housing Materials/Labor Cost & $\$ 98$ & /sqft & $\$ 46,922,400$ \\
\hline
\end{tabular}

\begin{tabular}{|l|l|l|l} 
Hook Up Costs & $\$ 3,864$ & per lot & $\$ 1,233,389$ \\
\hline
\end{tabular}

\begin{tabular}{|l|l|l|l|}
\hline & $\$ 8,000$ & 1 & $\$ 8,000$ \\
\hline
\end{tabular}

Toilet Construction + Hook up

Ramp Installation (2 per corner)

\begin{tabular}{l} 
Benches (every $125 \mathrm{~m}$ of road) \\
\hline Simple Black and White Signs (57 Total)
\end{tabular}

Crossings

\begin{tabular}{l} 
Internal Crossing (Pedestrian Crossing + \\
\hline
\end{tabular} Striped)
Internal Crossing (High Visibility Crossing)

External Crossings with APS (5 Total)*

*It is assumed that the Tow itself at $\$ 150,000$ each
Community Post Box Pavillion

Fommunity Post Box Pavillion

$\$ 22,000$

internal intersection
Landscaped Median $(3 \mathrm{~m} \times 3 \mathrm{~m}) 1$ per external $\$ 375.00$

\begin{tabular}{l} 
intersection \\
\hline Trellis \\
\hline
\end{tabular}

$\$ 15,000$

TOTAL HARD COSTS

\begin{tabular}{|l|l|l|}
\hline SOFT COSTS & \multicolumn{2}{|l|}{} \\
\hline Soft Costs (per sqft of house) & $\$ 50,70$ & $\$ 24,275,160$ \\
\hline Town of Whitby DC & $\$ 9,479$ & \\
\hline Region of Durham DC & $\$ 20,749$ & \\
\hline Educational DC & $\$ 2,735$ & \\
\hline Development Charges Total & $\$ 32,963$ & $\$ 10,521,790$ \\
\hline New Architectural Design Per & $\$ 3,000$ & \\
Style & & \\
\hline $\begin{array}{l}\text { New Architectural Design Per } \\
\text { Model }\end{array}$ & $\$ 1,125$ & \\
\hline Number of Styles Per Street & 2 & \\
\hline Number of Models Per Street & 2 & $\$ 33,000$ \\
\hline $\begin{array}{l}\text { Multiplied by the \# of streets } \\
\text { (minus 1) }\end{array}$ & 4 & \\
\hline
\end{tabular}

FINANCING

\begin{tabular}{l|l|l|}
\hline Construction Loan Cost & $10 \%$ & $\$ 9,756,4988$ \\
\hline
\end{tabular}

\begin{tabular}{|l|l|l}
\hline Contingency Fund (on hard/soft & $5 \%$ & $\$ 4,378,249$ \\
\hline
\end{tabular}

costs)

\begin{tabular}{l|l|l}
\hline Total Costs & $\$ 6,855,554,26$ \\
\hline
\end{tabular}

RATE OF RETURN

Revenues - costs (cash flow)

\begin{tabular}{l|l|l|l} 
& $\$ 118,555,284$ \\
\hline $25 \%$ & $\$ 29,638,820,99$ \\
\hline
\end{tabular}

Cash flow / Equity (ROE)

$\$ 9,124,716$

$30.7864 \%$

\section{LEGEND}

Core Recommendations \#2-17
TOTAL SOFT COSTS $\$ 34,829,949.60$ 


\begin{tabular}{|c|c|c|c|}
\hline \multicolumn{4}{|l|}{ LAND COSTS } \\
\hline Land Area (acre) & & 20.0 & \\
\hline Developable Land & & 19.0 & \\
\hline Average Land Cost (per acre) & & $\$ 500,000$ & \\
\hline Land Cost & & $\$ 10,000,000.00$ & \\
\hline \multicolumn{4}{|l|}{ BUILT FORM ASSUMPTIONS } \\
\hline \multirow{3}{*}{ \# of Residential Lots (net/acre) } & 1500 & sqft & \\
\hline & 16.8 & 255 & \\
\hline & & $\$ 400,000$ & \\
\hline Total expected Revenues & & $\$ 102,144,000$ & \\
\hline Total Linear Metres of Roads & & 1010 & \\
\hline$\%$ of Development Townhouse & 0.8 & 15.2 & acres \\
\hline \% of Development Mixed Use & 0.2 & 3.8 & acres \\
\hline Mixed Use Lot Coverage & $40 \%$ & 165528 & sqft \\
\hline 1 Floor GFA $=$ & & 66211.2 & sqft \\
\hline Floors (Above Ground) & 4 & & \\
\hline Gross Floor Area & 264845 & sqft & \\
\hline GLA (70\% of GFA) & $70 \%$ & 185391.36 & sqft \\
\hline 1 Floor GLA $=$ & & 46347.84 & sqft \\
\hline Residential GLA (3 Floors) & 3 & 139043.52 & sqft \\
\hline 1 bedroom (800sqft) & $33 \%$ & 46301.49216 & sqft \\
\hline$\#$ of 1 bedroom units & 800 & 58 & units \\
\hline Average Sale Price of 800 sqft unit & & $\$ 319,127$ & \\
\hline Residential Revenues & & $\$ 18,470,051$ & \\
\hline 2 bedroom (1200sqft) & $67 \%$ & 92602.98432 & sqft \\
\hline \# of 2 bedroom units & 1200 & 77 & units \\
\hline Average Sale Price of 1200 sqft unit & & $\$ 385,990$ & \\
\hline Residential Revenues & & $\$ 29,786,522$ & \\
\hline Retail GLA (1 Floor) & & 46347.84 & sqft \\
\hline Retail Cost per sqft & $\$ 274$ & $\$ 12,699,308$ & \\
\hline \multicolumn{4}{|l|}{ ROAD CALCULATION } \\
\hline Roads as \% of subdivision & $29.6 \%$ & & \\
\hline Roads as acres & & 4.49 & acres \\
\hline Roads in $\mathrm{m} 2$ (1acre $=4046 \mathrm{~m})$ & 4047 & 18177.5052 & $\mathrm{~m}^{2}$ \\
\hline $\begin{array}{l}\text { Linear metres of Road (Standard of } \\
\text { 18m width) }\end{array}$ & 18 & 1009.8614 & $\mathrm{~m}$ \\
\hline
\end{tabular}

\begin{tabular}{|c|c|c|c|}
\hline \multicolumn{4}{|l|}{ HARD COSTS } \\
\hline Road Construction & $\$ 2,300$ & per $\mathrm{m}$ & $\$ 2,322,681$ \\
\hline Sidewalk (2m wide + non-slip) & $\$ 160$ & per $\mathrm{m}$ & $\$ 161,578$ \\
\hline Buffer Zone (10ft wide) & $\$ 89$ & per $\mathrm{m}$ & $\$ 89,878$ \\
\hline Street Lighting + Hydro & 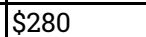 & per metre & $\$ 282,761$ \\
\hline Tree Planting ( 0.8 per lot $)$ & $\$ 400$ & & $\$ 81,715$ \\
\hline Housing Materials/Labor Cost -Townhouse & $\$ 98$ & /sqft & $\$ 37,537,920$ \\
\hline Hook Up Costs & $\$ \$ 3,864$ & per lot & $\$ 998,711$ \\
\hline $\begin{array}{l}\text { Mixed Use Building Materials/Labor } \\
\text { (Multiplied by GLA) }\end{array}$ & $\$ 195$ & per GSF & $\$ 36,151,315$ \\
\hline Enclosed Bus Shelter (each) & $\$ 8,000$ & 1 & $\$ 8,000$ \\
\hline Toilet Construction + Hook up & $\$ 450,000$ & & $\$ 450,000$ \\
\hline Ramp Installation (2 per corner) & $\$ 46.95$ & per ramp & $\$ 4,507$ \\
\hline Benches (every 125m of road) & $\$ 1,000$ & per bench & $\$ 8,079$ \\
\hline Simple Black and White Signs (64 Total) & $\$ 500$ & each & $\$ 32,000$ \\
\hline Crossings & & \begin{tabular}{|l}
$\begin{array}{l}\text { \# of } \\
\text { intersectio } \\
\text { ns }\end{array}$ \\
\end{tabular} & \\
\hline $\begin{array}{l}\text { Internal Crossing (Pedestrian Crossing + } \\
\text { Striped) }\end{array}$ & $\$ 10,661.44$ & 1 & $\$ 10,661$ \\
\hline Internal Crossing (High Visibility Crossing) & $\$ 15,975$ & 6 & $\$ 95,850$ \\
\hline External Crossings with APS (5 Total)* & $\$ 10,000$ & 5 & $\$ 50,000$ \\
\hline Itt is assumed that the Town or Region with $C$ & Cover the co & st of the Sigr & alized intersection \\
\hline Community Post Box Pavillion & $\$ 22,000$ & & $\$ 22,000$ \\
\hline $\begin{array}{l}\text { Flower Pots with Plantings (3ftx3ft) } 2 \text { per } \\
\text { internal intersection }\end{array}$ & $\$ 1,500$ & 2 & $\$ 21,000.00$ \\
\hline $\begin{array}{l}\text { Landscaped Median }(3 \mathrm{~m} \times 3 \mathrm{~m}) 1 \text { per external } \\
\text { intersection }\end{array}$ & $\$ 375.00$ & 1 & $\$ 1,875.00$ \\
\hline Trellis & $\$ 15,000$ & 1 & $\$ 15,000$ \\
\hline
\end{tabular}

TOTAL HARD COSTS

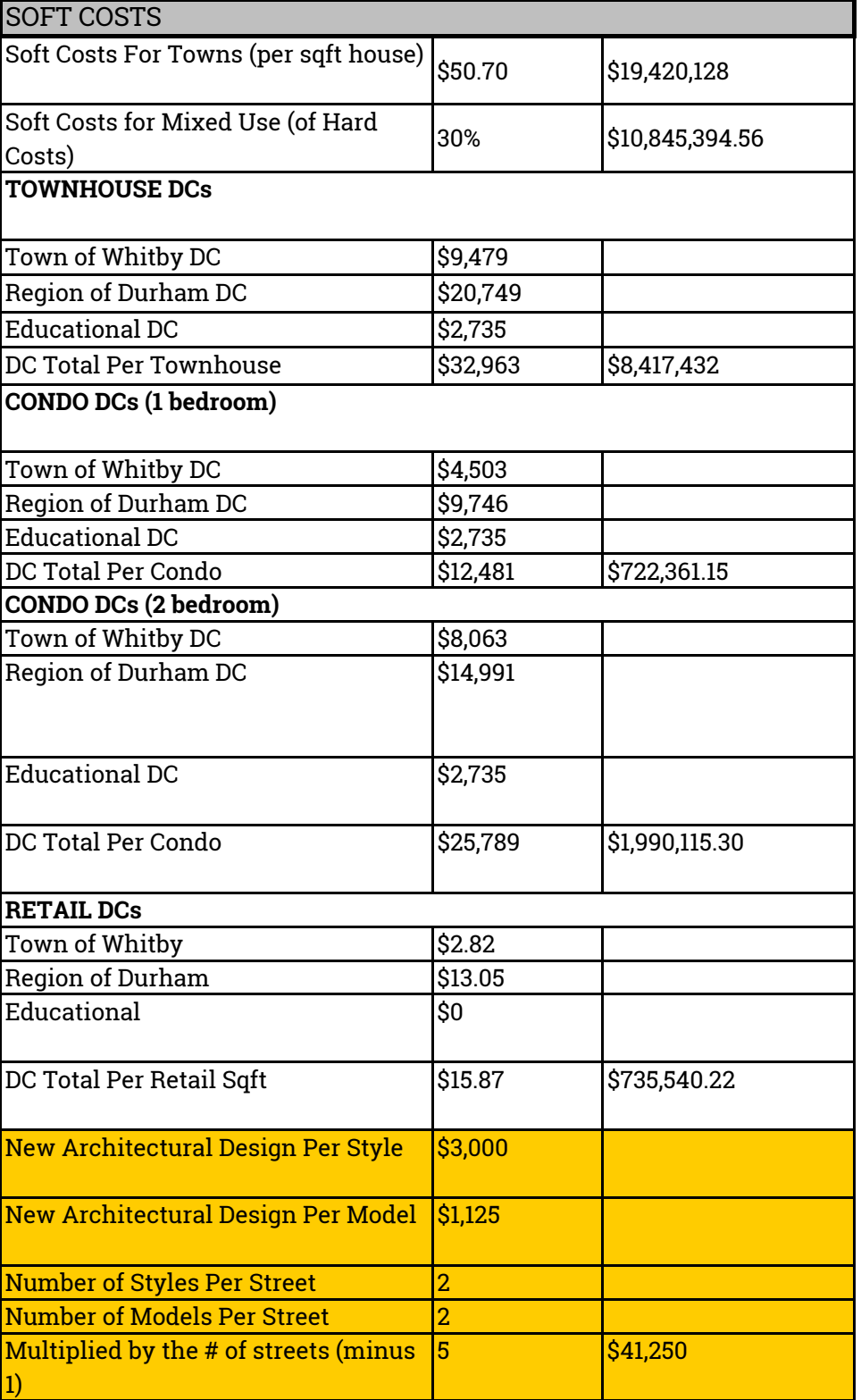

$\$ 78,333,531.87$ TOTAL SOFT COSTS
$\$ 42,172,220.92$
FINANCING

\begin{tabular}{|l|l|l|}
\hline Land + Hard + Soft Costs Total & & $\$ 130,505,752.79$ \\
\hline Construction Loan Cost & $10 \%$ & $\$ 13,050,575$ \\
\hline $\begin{array}{l}\text { Contingency Fund (on hard/soft } \\
\text { costs) }\end{array}$ & $5 \%$ & $\$ 6,025,288$ \\
\hline GST + PST & & $\$ 10,183,359.14$ \\
\hline Total Costs & & $\$ \$ 59,764,975$ \\
\hline Equity & $25 \%$ & $\$ 39,941,243.71$ \\
\hline RATE OF RETURN & & $\$ 3,334,906$ \\
\hline Revenues - costs (cash flow) & & $8.3495 \%$ \\
\hline Cash flow / Equity (ROE) & & 8.349 \\
\hline
\end{tabular}

LEGEND

Core Recommendations \#2-17 .

\begin{tabular}{l|l|l} 
& \\
\hline & &
\end{tabular}

$18 \mathrm{~m}$ width) 
APPENDIX 17B: EVERYTHING (THE EFFECT OF RECOMMENDATIONS H1 - \#17) WITH INCENTIVES PRO FORMA ASSUMPTIONS

\begin{tabular}{|c|c|c|c|}
\hline Road Construction & $\$ 2,300$ & per $\mathrm{m}$ & $\$ 2,322,681$ \\
\hline iidewalk (2m wide + non-slip) & $\$ 160$ & per $m$ & $\$ 161,578$ \\
\hline Suffer Zone (10ft wide) & $\$ 89$ & per $\mathrm{m}$ & $\$ 89,878$ \\
\hline Street Lighting + Hydro & $\$ 280$ & per metre & $\$ 282.761$ \\
\hline Tree Planting (0.8 per lot) & $\$ 400$ & 0.8 & $\$ 81,715$ \\
\hline Housing Materials/Labor Cost -Townhouse & & /sqft & $\$ 37,537,920$ \\
\hline Hook Up Costs & $\$ 3,864$ & per lot & $\$ 986,711$ \\
\hline $\begin{array}{l}\text { Mixed Use Building Materials/Labor } \\
\text { (Multiplied by GLA) }\end{array}$ & $\$ 195$ & per GSF & $\$ 36,151,315$ \\
\hline Enclosed Bus Shelter (each) & $\$ 8,000$ & 1 & $\$ 8,000$ \\
\hline Toilet Construction + Hook up & $\$ 450,000$ & & $\$ 450,000$ \\
\hline Ramp Installation (2 per corner) & $\$ 46.95$ & per ramp & $\$ 4,507$ \\
\hline Senches (every $125 \mathrm{~m}$ of road) & $\$ 1,000$ & per bench & $\$ 8,079$ \\
\hline Simple Black and White Signs (64 Total) & $\$ 500$ & each & $\$ 32,000$ \\
\hline rossings & & $\begin{array}{l}\text { \# of } \\
\text { intersectio } \\
\text { ns }\end{array}$ & \\
\hline $\begin{array}{l}\text { Internal Crossing (Pedestrian Crossing + } \\
\text { Striped) }\end{array}$ & $\$ 10,661.44$ & 1 & $\$ 10,661$ \\
\hline Internal Crossing (High Visibility Crossing) & $\$ 15,975$ & 6 & $\$ 95,850$ \\
\hline External Crossings with APS (5 Total) ${ }^{\star}$ & $\$ 10,000$ & 5 & $\$ 50,000$ \\
\hline $\begin{array}{l}\text { It is assumed that the Town or Region with C } \\
\text { Community Post Box Pavillion }\end{array}$ & $\begin{array}{l}\text { Cover the co } \\
\$ 22,000\end{array}$ & st of the Sign & alized intersecti \\
\hline $\begin{array}{l}\text { Flower Pots with Plantings (3ftx3ft) } 2 \text { per } \\
\text { internal intersection }\end{array}$ & $\$ 1,500$ & 2 & $\$ 21,000.00$ \\
\hline $\begin{array}{l}\text { Landscaped Median }(3 \mathrm{~m} \times 3 \mathrm{~m}) 1 \text { per external } \\
\text { intersection }\end{array}$ & $\$ 375.00$ & 1 & $\$ 1,875.00$ \\
\hline Trellis & $\$ 15,000$ & 1 & $\$ 15,000$ \\
\hline $\begin{array}{l}\text { SUBTRACT the following reduction: } \\
\text { KVTPI, } 2013 \text { (\$25,000 per parking spot) }\end{array}$ & & & \\
\hline Per Dwelling Unit (25\% reduction) & 1.25 & 42 & $\$ 791,285$ \\
\hline er Dwelling Unit for Visitors (25\% reduction) & 0.25 & 8 & $\$ 158,257$ \\
\hline
\end{tabular}

TOTAL HARD COSTS

$\$ 77,383,989.55$

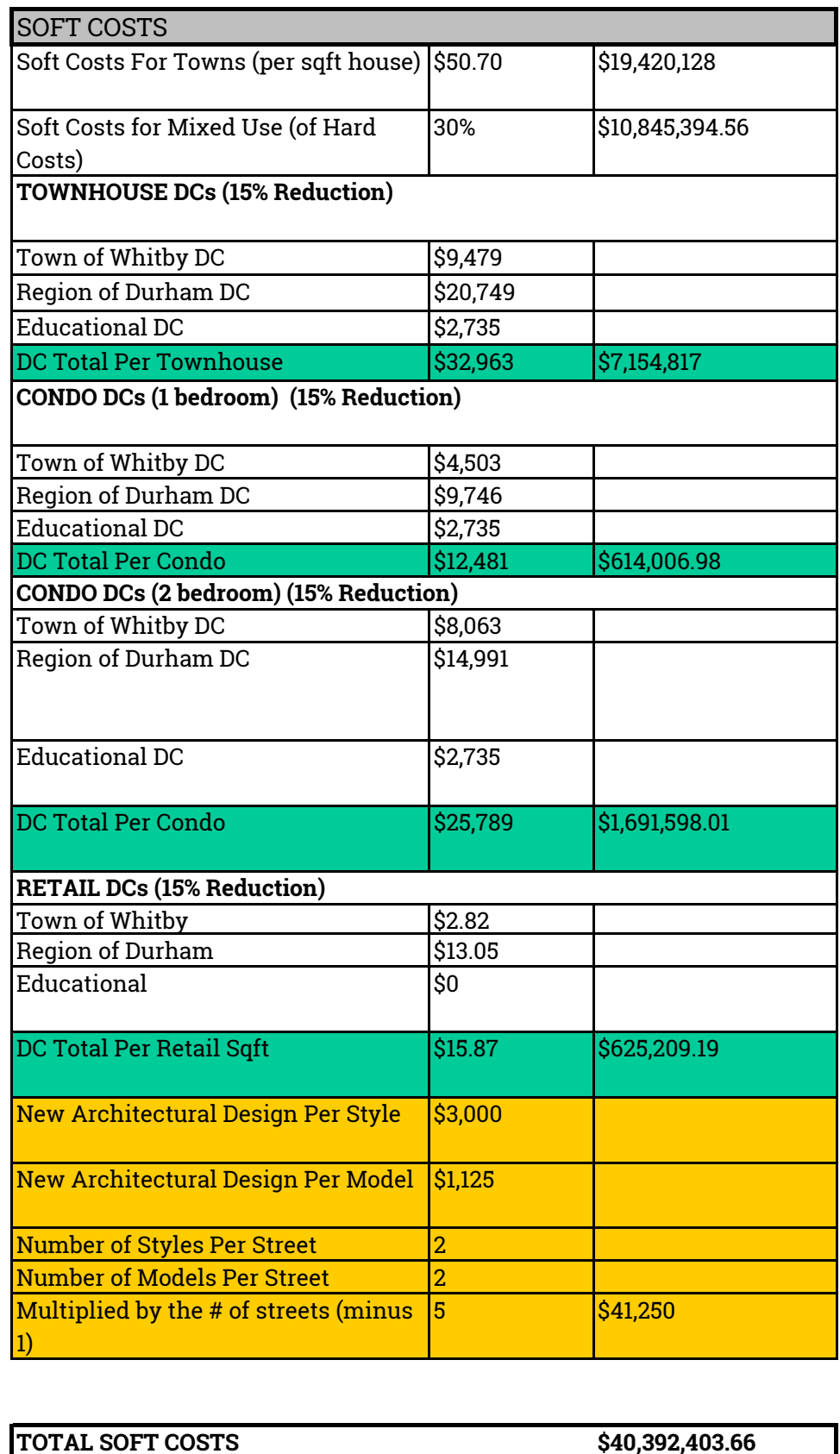

TOTAL SOFT COSTS

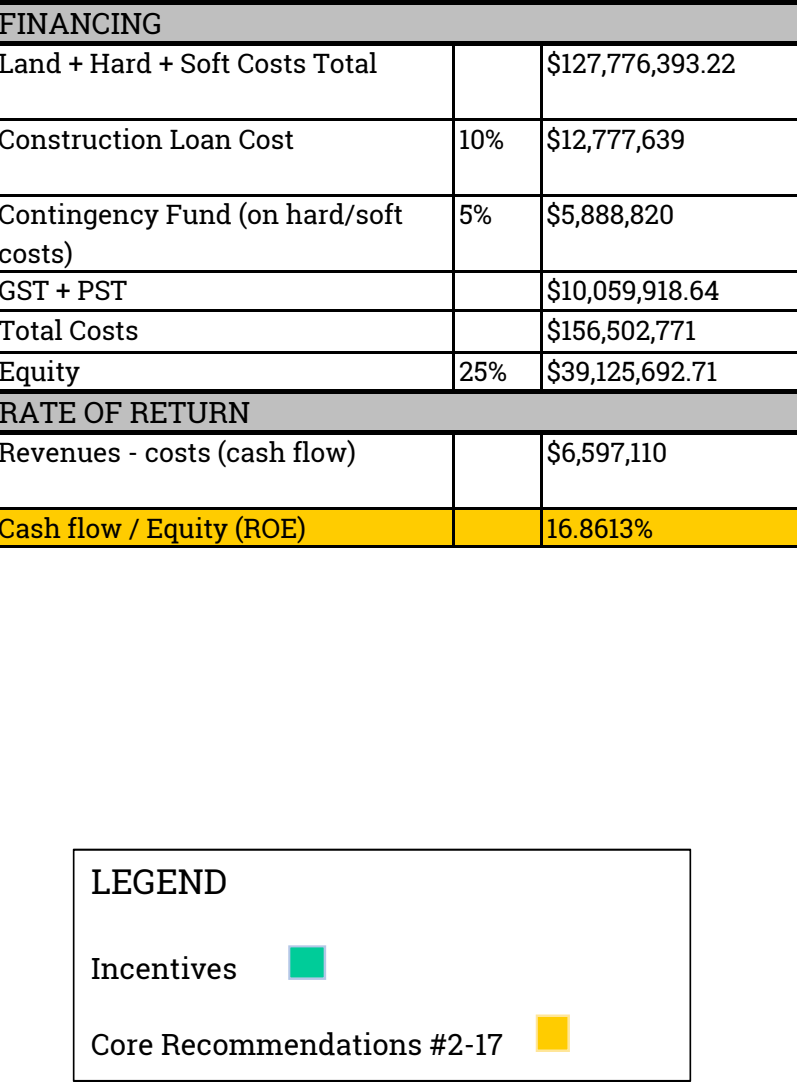

Core Recommendations \#2-17

\begin{tabular}{|c|c|c|c|}
\hline \multicolumn{4}{|l|}{ LAND COSTS } \\
\hline Land Area (acre) & & 20.0 & \\
\hline Developable Land & & 19.0 & \\
\hline Average Land Cost (per acre) & & $\$ 500,000$ & \\
\hline Land cost & & $\$ 10,000,000.00$ & \\
\hline \multicolumn{4}{|l|}{ BUILT FORM ASSUMPTIONS } \\
\hline \begin{tabular}{|l|l|} 
Average Townhouse Size \\
\end{tabular} & 1500 & sgft & \\
\hline \multirow{2}{*}{ \# of Residential Lots (net/acre) } & 16.8 & 255 & \\
\hline & & $\$ 400,000$ & \\
\hline Total expected Revenues & & $\$ 102,144,000$ & \\
\hline Total Linear Metres of Roads & & & \\
\hline$\%$ of Development Townhouse & 0.8 & 15.2 & \\
\hline$\%$ of Development Mixed Use & 0.2 & 3.8 & \\
\hline \begin{tabular}{|l} 
Mixed Use Lot Coverage \\
\end{tabular} & $40 \%$ & 165528 & sqft \\
\hline 1 Floor $\mathrm{GFA}=$ & & 66211.2 & sqft \\
\hline Floors (Above Ground) & 4 & & \\
\hline Gross Floor Area & 264845 & sqft & \\
\hline GLA (70\% of GFA) & $70 \%$ & 185391.36 & sqft \\
\hline 1 Floor GLA $=$ & & 46347.84 & \\
\hline Residential GLA (3 Floors) & 3 & 139043.52 & sqft \\
\hline 1 bedroom (800sqft) & $33 \%$ & 46301.49216 & sqft \\
\hline \# of 1 bedroom units & 800 & 58 & units \\
\hline Average Sale Price of 800 sqft unit & & $\$ 319,127$ & \\
\hline Residential Revenues & & $\$ 18,470,051$ & \\
\hline 2 bedroom (1200sqft) & $67 \%$ & 92602.98432 & sqft \\
\hline \# of 2 bedroom units & 1200 & 77 & units \\
\hline Average Sale Price of 1200 sqft unit & & $\$ 385,990$ & \\
\hline Residential Revenues & & $\$ 29,786,522$ & \\
\hline Retail GLA (1 Floor) & 1 & 46347.84 & sqft \\
\hline Retail Cost per sqft & $\$ 274$ & $\$ 12,699,308$ & \\
\hline \multicolumn{4}{|l|}{ ROAD CALCULATION } \\
\hline Roads as \% of subdivision & $29.6 \%$ & & \\
\hline Roads as acres & & 4.49 & acre \\
\hline Roads in m2 (1acre=4046m) & 4047 & 18177.5052 & $\mathrm{~m}^{2}$ \\
\hline $\begin{array}{l}\text { Linear metres of Road (Standard of } \\
18 \mathrm{~m} \text { width) }\end{array}$ & $\mathrm{f} 18$ & 1009.8614 & $\mathrm{~m}$ \\
\hline
\end{tabular}




\section{APPENDIX 18 - COMMUNITY IMPROVEMENT PLANS}

A Community Improvement Plan (CIP) is a planning tool allowing a municipality to direct funds and implement policy initiatives toward a specifically defined project area, after a thorough and complete study of community needs. Section 28 of the Planning Act, 1990 permits municipalities to designate CIP areas and create CIPs that adhere to the definition of 'community improvement' under Section 28. Grants and loans may be provided for the following: environmental site assessment, environmental remediation, development, redevelopment as well as construction and reconstruction of lands and buildings for the rehabilitation process (Sec. 28 (7.1)).

Under the Municipal Act, 2001, municipalities are prohibited from providing bonusing or grants, unless it is through Section 106(3), which allows the aforementioned only if it is done using Sec. 28(6), (7) or (7.2) of the Planning Act (i.e. through Community Improvement Planning). This is an especially important clause as it forces municipalities to undergo a rigorous study process of their CIP area, conduct a thorough assessment of community needs, and complete a public consultation prior to providing financial incentives to private developers. Lastly, in order to implement Section 28, the municipality must have provisions in its Official Plan to allow for municipality-wide and area-specific CIPs (Town of Whitby already does this through Section 6.3 of their Official Plan).

As per the Planning Act, a municipality may engage in the following activities in CIP areas:

- Acquire, hold, clear, grade or otherwise prepare land for community improvement (28 (3));

- Construct, repair, rehabilitate or improve buildings on land acquired or held by it in the community improvement project area in conformity with the community improvement plan (28(6));

- Sell, lease, or otherwise dispose of any land and buildings acquired or held by it in the community improvement project area to any person or government authority for use in conformity with the community improvement plan (28(6)); and

- Make grants or loans, in conformity with the community improvement plan, to registered owners, assessed owners and tenants of lands and buildings within the community improvement project area. In addition to any person such an owner or tenant has assigned the right to receive a grant or loan, to pay for the whole or any part of the eligible costs of the community improvement plan (28(7)).

If a CIP is to be pursued, the Town of Whitby must amend their Official Plan to include the policies of the CIP (including the area, a definition of the need for the program(s), program explanation, and eligibility requirements). 


\section{Needs Assessment +} Community Buy-in

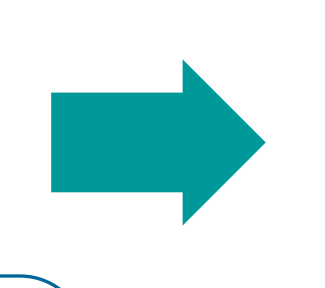

- Identify community needs (based on Sec. 28)

- Seek community input

- Report to Council on

findings + request

authorization to begin CIP

process

- Collect data on all aspects

of proposed study area

- Background analysis of all

relevant policy (planning,

land use, housing, etc.)

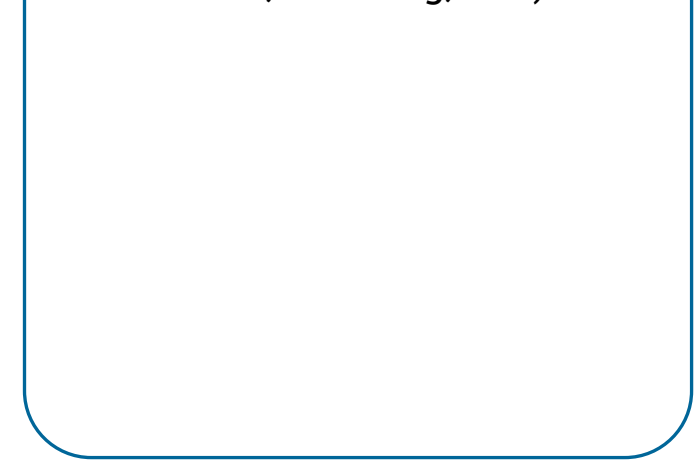

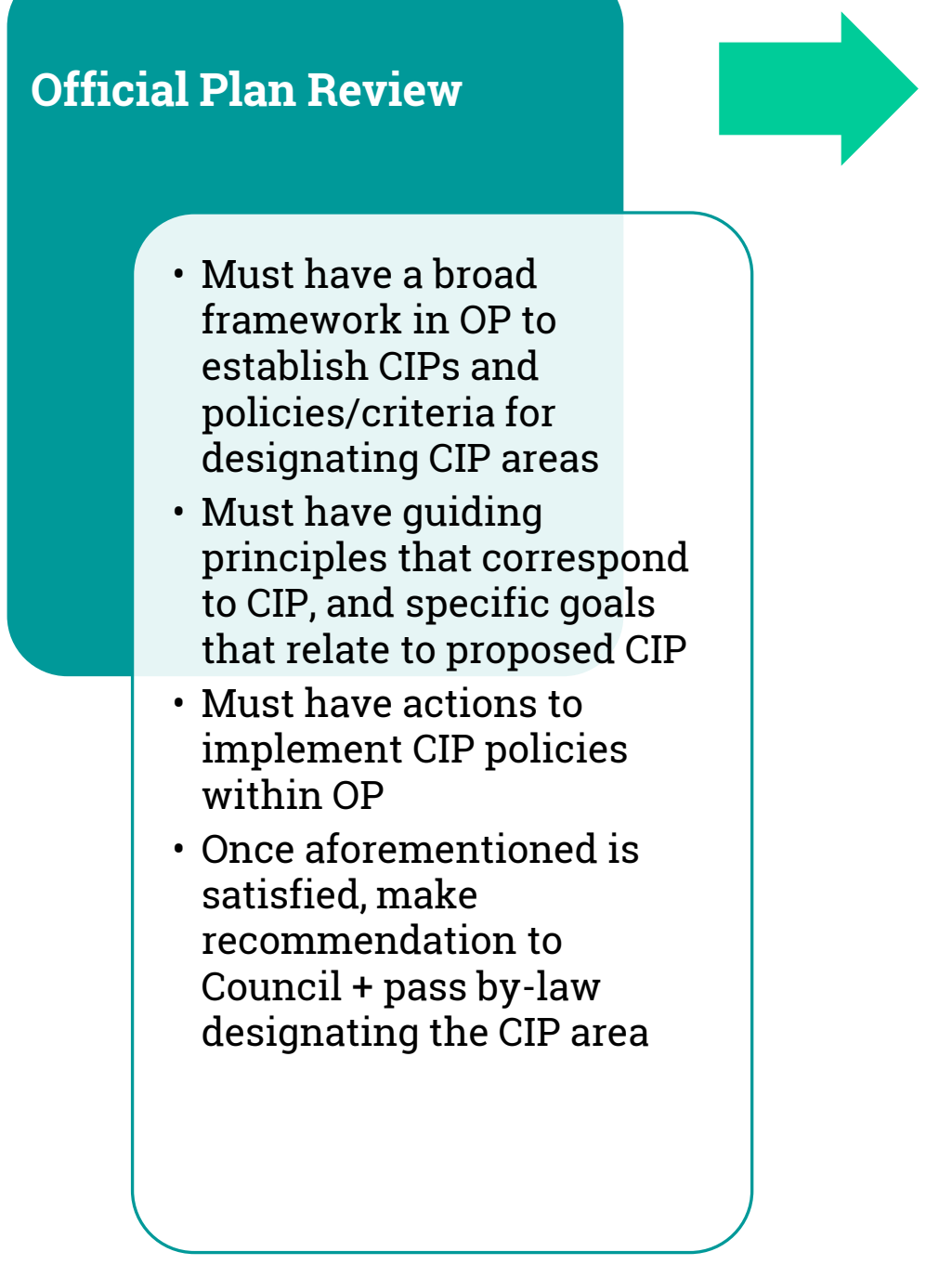

Finalize + Implement

- Respond to any comments from MMAH or appeals from public

- Adopt CIP by Council vote

- Implement internal Action

Plan (establish marketing

programs, conduct ongoing

screening and approval of

projects, adminster

agreements + programs)

- Monitor each program +

service delivery

- Make adjustments ctices, marketing, staff

ining, cost estimates)

- Report to Council + finalize

draft

- Circulate to MMAH + have public meeting. (20 day appeal period) 


\section{APPENDIX 19 - CURRENT PLANNING FRAMEWORKS EXERPTS}

\begin{tabular}{|c|c|}
\hline \multicolumn{2}{|c|}{ Provincial Policy Statement, 2014} \\
\hline 1.1 & $\begin{array}{l}\text { Managing and Directing Land Use to Achieve Efficient and Resilient } \\
\text { Development and Land Use Patterns states that "Healthy, liveable and safe } \\
\text { communities are sustained by: } \\
\text { f) improving accessibility for persons with disabilities and older persons by } \\
\text { identifying, preventing and removing land use barriers which restrict their full } \\
\text { participation in society. }\end{array}$ \\
\hline 1.5 .1 & $\begin{array}{l}\text { Healthy, active communities should be promoted by: } \\
\text { a) planning public streets, spaces and facilities to be safe, meet the needs of } \\
\text { pedestrians, foster social interaction and facilitate active transportation and } \\
\text { community connectivity; } \\
\text { b) planning and providing for a full range and equitable distribution of publicly- } \\
\text { accessible built and natural settings for recreation, including facilities, } \\
\text { parklands, public spaces, open space areas, trails and linkages, and, where } \\
\text { practical, water-based resources. }\end{array}$ \\
\hline 4.6 & $\begin{array}{l}\text { This Provincial Policy Statement shall be implemented in a manner that is } \\
\text { consistent with the Ontario Human Rights Code and the Canadian Charter of } \\
\text { Rights and Freedoms. }\end{array}$ \\
\hline \multicolumn{2}{|c|}{ Growth Plan for the Greater Golden Horseshoe, 2006 (Office Consolidation 2013) } \\
\hline $2.2 .2 .1 \mathrm{~d})$ & $\begin{array}{l}\text { Population and employment growth will be accommodated by - } \\
\text { (c) building compact, transit-supportive communities in designated } \\
\text { greenfield areas } \\
\text { (d) reducing dependence on the automobile through the development of } \\
\text { mixed-use, transit-supportive, pedestrian-friendly urban environments }\end{array}$ \\
\hline $\begin{array}{l}2.2 .7 \\
2.22\end{array}$ & $\begin{array}{l}\text { Growth in greenfield areas shall be compact and transit-supportive (2.22). It } \\
\text { shall be planned, designated, zoned and designed in a manner that creates } \\
\text { street configurations, destines and urban form that support walking, cycling } \\
\text { and transit, as well as create high quality public open space that through its } \\
\text { design, supports transit, walking and cycling (2.27). }\end{array}$ \\
\hline \multicolumn{2}{|c|}{ Region of Durham Official Plan, 2013} \\
\hline $\begin{array}{l}2.2 .5 \\
2.3 .5\end{array}$ & $\begin{array}{l}\text { Development within the Region shall take aesthetics into account (2.2.5) by } \\
\text { promoting the enhancement of visual amenities of the urban environment and } \\
\text { enacting by-laws establishing environmental, aesthetic, urban design and } \\
\text { controls on signs and outdoor lighting (2.3.5). }\end{array}$ \\
\hline 2.2 .10 & $\begin{array}{l}\text { Urban Areas shall be developed to support a pedestrian-oriented urban } \\
\text { environment which promotes social interaction and provides opportunities for } \\
\text { free expression and the nourishment of culture and art. }\end{array}$ \\
\hline 2.3 .47 & $\begin{array}{l}\text { Regional Council shall promote tree planting for the purposes of improving air } \\
\text { quality, health and reducing energy use through shading and sheltering. }\end{array}$ \\
\hline 4.3 .1 & $\begin{array}{l}\text { In areas outside of Urban Areas, housing choice shall largely be limited to } \\
\text { single detached dwellings, consistent with the character of the area. }\end{array}$ \\
\hline $\begin{array}{l}8.1 .4 \\
8.1 .10\end{array}$ & $\begin{array}{l}\text { Develop people-oriented Urban Areas that create a sense of community, } \\
\text { promote social interaction and area aesthetically pleasing. }\end{array}$ \\
\hline
\end{tabular}




\begin{tabular}{|c|c|}
\hline $\begin{array}{l}8.3 .10 \\
8.2 .1\end{array}$ & $\begin{array}{l}\text { Include urban design guidelines and transit supportive development policies in } \\
\text { municipal Official Plans (8.3.10) that encourage the development of compact } \\
\text { urban form, fosters the creation of a grid system of roads, and provide linkages } \\
\text { for pedestrians and cyclists (8.2.1). }\end{array}$ \\
\hline 8.2 .1 & $\begin{array}{l}\text { Urban Areas shall be planned and developed with regard for the principles of } \\
\text { adaptability over time, sustainable development, harmony with nature and } \\
\text { diversity and integration of structures and functions. }\end{array}$ \\
\hline $\begin{array}{l}8 C .1 .6 \\
8 C .2 .9\end{array}$ & $\begin{array}{l}\text { The Region shall promote sustainable design and the development of transit } \\
\text { supportive, compact urban form that encourages ative transit (8C.2.9). }\end{array}$ \\
\hline 11.3.34 & $\begin{array}{l}\text { In the consideration of development applications abutting arterial roads where } \\
\text { access opportunities are limited, development patterns that promote } \\
\text { pedestrian connectivity and permeability to the arterial road will be supported } \\
\text { by: } \\
\text { a) minimizing the amount of reverse lot frontage along the arterial road; } \\
\text { b) promoting alternatives to reverse lot frontage such as window streets } \\
\text { and cul-de-sacs adjacent to the arterial road; } \\
\text { c) providing noise attenuation walls or fencing, where applicable, along } \\
\text { the sideyard of lots adjacent to the arterial road; and } \\
\text { d) establishing direct visual and pedestrian connections from proposed } \\
\text { land uses and/or local streets and to the arterial road. }\end{array}$ \\
\hline \multicolumn{2}{|c|}{ Town of Whitby Official Plan, Office Consolidation 2010} \\
\hline 4.2.3.1 & $\begin{array}{l}\text { Non-residential uses are permitted in non-residential areas if they are: limited } \\
\text { in scale, low intensity and compatible in design and scale to surrounding } \\
\text { community. }\end{array}$ \\
\hline 4.2.3.13 & $\begin{array}{l}\text { Location of medium and high density residential uses shall address: lot size, } \\
\text { setbacks, sideyards, impact of height and design and form on adjacent uses } \\
\text { and proximity to public transit, retail, services and institutions, road access } \\
\text { suitability, provision of parking, lighting and landscaping. }\end{array}$ \\
\hline 4.2.3.14 & $\begin{array}{l}\text { Lands designated medium and high density residential shall be developed on } \\
\text { the basis of comprehensive site plans taking into account good urban design } \\
\text { principles. }\end{array}$ \\
\hline 8.1.3.1.7 & $\begin{array}{l}\text { The Municipality will encourage a more grid-oriented street network in the } \\
\text { planning of new development areas in order to distribute vehicular traffic more } \\
\text { evenly, and provide for more accessible and efficient transit services. }\end{array}$ \\
\hline $\begin{array}{l}8.1 .3 .8 .5 \\
8.1 .3 .8 .6 \\
8.1 .3 .8 .7\end{array}$ & $\begin{array}{l}\text { Major development applications and plans of subdivision shall be reviewed and } \\
\text { assessed to incorporate the needs of the public transit service within the public } \\
\text { street system to assist in the creation of a transit supportive urban area. Roads } \\
\text { needed to serve as transit routes will be given consideration in the initial } \\
\text { stages of development to encourage transit use at an early stage, subject to } \\
\text { operation and financial feasibility. As a target, a network of transit tours in } \\
\text { urban areas shall be developed to ensure that patrons generally have a } \\
\text { maximum walking distance of } 400 \text { metres to transit. }\end{array}$ \\
\hline 8.1.3.7.10 & $\begin{array}{l}\text { Wherever possible in the design of bicycle and/or pedestrian facilities, Council } \\
\text { shall encourage and support measures which will improve their accessibility } \\
\text { for handicapped. }\end{array}$ \\
\hline
\end{tabular}




\begin{tabular}{|l|l|}
\hline 10.1.13.4 & $\begin{array}{l}\text { Site plan control areas shall address the following (which relates to this core } \\
\text { recommendation), among other matters: } \\
\text { B) sustainable and accessible design elements within, or adjacent to, an } \\
\text { adjoining municipal right-of-way, including without limitation, trees, } \\
\text { landscaping, permeable paving materials, street furniture, curb ramps, waste } \\
\text { and recycling containers and bicycle parking facilities; } \\
\text { C) facilities designed to have regard for accessibility for persons with } \\
\text { disabilities. }\end{array}$ \\
\hline 11.8.7.2 & $\begin{array}{l}\text { A range of tenure types and built forms shall be encouraged to serve a variety } \\
\text { of housing needs within the Major Central Area. }\end{array}$ \\
\hline
\end{tabular}


APPENDIX 20 - Frequency of 17 Core Recommendations in the selected Dementia * Built Environment Literature

\begin{tabular}{|c|c|c|c|c|c|c|c|c|c|c|c|c|c|c|}
\hline Recommendation & Keywords Used & $\begin{array}{l}\text { Blackman } \\
\text { et al. } 2003\end{array}$ & $\begin{array}{l}\text { Mitchell } \\
\text { et al. } 2003\end{array}$ & $\begin{array}{l}\text { Sheehan } \\
\text { et al. } 2003\end{array}$ & $\begin{array}{l}\text { Blackman } \\
\text { et al. } 2007\end{array}$ & $\begin{array}{l}\text { Van } \\
\text { Schaik et } \\
\text { al. } 2008 \\
\end{array}$ & $\begin{array}{l}\text { Duggan et } \\
\text { al. } 2008\end{array}$ & $\begin{array}{l}\text { Brittain et } \\
\text { al. } 2010\end{array}$ & $\begin{array}{l}\text { Brorsson } \\
\text { et al. } 2011\end{array}$ & $\begin{array}{l}\text { Brorsson } \\
\text { et al. } 2013\end{array}$ & $\begin{array}{l}\text { Brorsson } \\
\text { et al. } 2014\end{array}$ & $\begin{array}{l}\text { Shoval et } \\
\text { al. } 2011\end{array}$ & $\begin{array}{l}\text { CMHC, } \\
2014\end{array}$ & TOTAL \\
\hline $\begin{array}{l}\# 1 \text { Mixed Use } \\
\text { Areas }\end{array}$ & $\begin{array}{l}\text { "mix" "mixed" "use" "services" } \\
\text { "facilities" "open space" "shops" } \\
\text { "journey" "destination" }\end{array}$ & $\mathrm{x}$ & $\mathrm{x}$ & & $\mathrm{x}$ & & $\mathrm{x}$ & $\mathrm{x}$ & $\mathrm{x}$ & $\mathrm{x}$ & $\mathrm{x}$ & $\mathrm{x}$ & & 9 \\
\hline $\begin{array}{l}\text { \#2 Wide Smooth } \\
\text { Footways }\end{array}$ & $\begin{array}{l}\text { "mix" "mixed" "use" "services" } \\
\text { "facilities" "open space" "shops" } \\
\text { "journey" "destination" }\end{array}$ & $\mathrm{x}$ & $\mathrm{x}$ & & $\mathrm{x}$ & & & & & $\mathrm{x}$ & & & $\mathrm{x}$ & 5 \\
\hline \#3 Road Crossings & $\begin{array}{l}\text { "road crossing" "audible cue" } \\
\text { "visual cue" "crossing" } \\
\text { "crossroad" "distance" } \\
\text { "impairment" "pedestrian" }\end{array}$ & & $\mathrm{x}$ & & $\mathrm{x}$ & & & $\mathrm{x}$ & & $\mathrm{x}$ & $\mathrm{x}$ & & & 5 \\
\hline \#4 Clear Signs & "sign" "clear" & $\mathrm{x}$ & $\mathrm{x}$ & $\mathrm{x}$ & $\mathrm{x}$ & & & $\mathrm{x}$ & & $\mathrm{x}$ & & & $\mathrm{x}$ & 7 \\
\hline $\begin{array}{l}\text { \#5 Frequent } \\
\text { Seating }\end{array}$ & "seating" "sit" & $\mathrm{x}$ & $\mathrm{x}$ & & $\mathrm{x}$ & & & & $\mathrm{x}$ & & & & $\mathrm{x}$ & 5 \\
\hline $\begin{array}{l}\text { \#6 Small Blocks + } \\
\text { Grid }\end{array}$ & $\begin{array}{l}\text { "small block" "grid" "crossroad" } \\
\text { "street pattern" }\end{array}$ & $\mathrm{x}$ & $\mathrm{x}$ & & & & & & & & & & & 2 \\
\hline $\begin{array}{c}\text { \#7 Level Changes + } \\
\text { Handrails }\end{array}$ & $\begin{array}{l}\text { "level change" "handrail" "curb" } \\
\text { "stairs" }\end{array}$ & $\mathrm{x}$ & $\mathrm{x}$ & & & & & & & & $\mathrm{x}$ & & $\mathrm{x}$ & 4 \\
\hline $\begin{array}{l}\text { \#8 Ground level } \\
\text { toilets }\end{array}$ & "toilet" & & & & & & & $\mathrm{x}$ & & & & & $\mathrm{x}$ & 2 \\
\hline $\begin{array}{l}\text { \#9 Enclosed bus } \\
\text { shelter }\end{array}$ & "shelter" "bus" & $\mathrm{x}$ & $\mathrm{x}$ & & $\mathrm{x}$ & & & & & & $\mathrm{x}$ & & & 4 \\
\hline $\begin{array}{l}\text { \#10 Varied urban } \\
\text { form }\end{array}$ & $\begin{array}{l}\text { "urban form" "built form" } \\
\text { "architecture" "style" "different" } \\
\text { "varied" }\end{array}$ & $\mathrm{x}$ & $\mathrm{x}$ & & & & & & & & & & $\mathrm{x}$ & 3 \\
\hline \#11 Buffer Zones & "buffer" "separation" & $\mathrm{x}$ & $\mathrm{x}$ & & & & & & & & $\mathrm{x}$ & & & 3 \\
\hline \#12 Landmarks & $\begin{array}{l}\text { "landmark" "distinct" "structure" } \\
\text { "place of activity" "public space" }\end{array}$ & $\mathrm{x}$ & $\mathrm{x}$ & $\mathrm{x}$ & $\mathrm{x}$ & $\mathrm{x}$ & & $\mathrm{x}$ & $\mathrm{X}$ & $\mathrm{x}$ & & & $\mathrm{x}$ & 9 \\
\hline $\begin{array}{l}\text { \#13 Hierarchy of } \\
\text { Streets }\end{array}$ & "hierarchy" "streets" & $\mathrm{x}$ & & & & & & & & & $\mathrm{x}$ & & $\mathrm{x}$ & 3 \\
\hline $\begin{array}{c}\text { \#14 Distinct } \\
\text { Features at } \\
\text { junctions }\end{array}$ & "distinct" "junctions" & $\mathrm{x}$ & $\mathrm{x}$ & & & & & & $\mathrm{x}$ & & & & $\mathrm{x}$ & 4 \\
\hline $\begin{array}{l}\text { \#15 Buildings with } \\
\text { obvious entrances }\end{array}$ & $\begin{array}{l}\text { "obvious" "different" "entrance" } \\
\text { "building" }\end{array}$ & $\mathrm{x}$ & & & $\mathrm{x}$ & & & & $\mathrm{x}$ & & & & $\mathrm{x}$ & 4 \\
\hline $\begin{array}{l}\text { \#16 Designed to } \\
\text { reflect use }\end{array}$ & "designed to" & & & & & & & $\mathrm{x}$ & $\mathrm{x}$ & & & & $\mathrm{x}$ & 3 \\
\hline $\begin{array}{c}\# 17 \text { Gentle } \\
\text { Winding Streets }\end{array}$ & "street" "winding" "gentle" & $\mathrm{x}$ & $\mathrm{x}$ & & & & & & & & & & & 2 \\
\hline
\end{tabular}




\section{Reference List}

Accessibility for Ontarians with Disabilities Act, Revised Statutes of Ontario (2005, c.11). Retrieved from the Province of Ontario E-laws website: http://www.search.elaws.gov.on.ca/en/isysquery/e60249d4-c66b-4458-8d667c9blb263ce9/1/doc/?search=browseStatutes\&context=\#hit1

Accessibility for Ontarians with Disabilities Act: Ontario Regulation 191/11 Integrated Accessibility Standards (2013). Retrieved from: http://www.search.elaws.gov.on.ca/en/isysquery/e60249d4-c66b-4458-8d667c9b1b263ce9/4/doc/?search=browseStatutes\&context=\#hit1

Altus Group. (2015). “Construction Cost Guide 2015." Retrieved from: http://www.altusgroup.com/research/construction-cost-guide/cost-guide-download-form/

Bedford, P. (2013). Unlocking the Potential for Mid-rise Buildings - Six Storey Wood Structures. Prepared for the Building Industry and Land Development Association. Retrieved from: http://wood-works.ca/wp-content/uploads/2013/12/nationalnews-Bedford_Report__Unlocking_the_Potential_for_Mid-Rise_Buildings_Six_Storey_Wood_Frame__2013_DRAFT.pdf

Bevan, M., \& Croucher, K. (2011). Lifetime Neighbourhoods. London, UK: Department of Communities and Local Government, Government of the United Kingdom. Retrieved from: https://www.gov.uk/government/uploads/system/uploads/attachment_data/file/6248/2044 122.pdf

Bickel, H., \& Cooper, B. (1994). Incidence and relative risk of dementia in an urban elderly population: findings of a prospective field study. Psychological Medicine, 24 (01), 179-192. doi:10.1017/S0033291700026945

Blackman, T., Mitchell, L., Burton, E., Jenks, M., Parsons, M., Raman, S., \& Williams, K. (2003). The Accessibility of Public Spaces for People with Dementia: A new priority for the "open city." Disability \& Society, 18 (3), 357-371. doi:10.1080/0968759032000052914

Blackman, T. (2006). Placing Health: Neighbourhood Renewal, Health Improvement and Complexity. Bristol: The Policy Press.

Blackman, T., Van Shaik, P., \& Martyr, A. (2007). Outdoor Environments for people with dementia: an exploratory study using virtual reality. Ageing and Society 6, 811-825.

Blackstock, K.L., Innes, A., Cox, B., Smith, A., \& Mason, A. (2006). Living with dementia in rural and remote Scotland: Diverse experiences of people with dementia and their careers. Rural Studies 22, 161-76.

Brittain, K.R., Corner, L., Robinson, L., \& Bond, J. (2010). Ageing in place and technologies of place: the lived experience of people with dementia in changing social, physical and technological environments. Sociology of Health and Illness, 32 (2), 272-287. 
Brorsson, A., Ohman, A., Lundberg, S., \& Nygard L. (2011). Accessibility in public space as perceived by people with Alzheimer's disease. Dementia, 10, 587-602.

Brorsson, A., Ohman, A., Cutchin, M., \& Nygard, L. (2013). "Managing critical incidents in grocery shopping by community-living people with Alzheimer's disease." Scandinavian Journal and Occupational Therapy, (2), 292-301.

Brorsson, A., Ohman, A., Lundberg, S. \& Nygard, L. (2014). "Being a pedestrian with dementia: A qualitative study using photo documentation and focus group interviews." Dementia O(O), 117.

Building Code Act: Ontario Regulation 332/12 Building Code (2015). Retrieved from the Province of Ontario E-laws website: http://www.elaws.gov.on.ca/html/regs/english/elaws_regs_120332_e.htm

Burton, E. \& Mitchell, L. (2006). Inclusive Urban Design: Streets for Life. Oxford: Elsevier Ltd.

Bushell, M., Poole, B., Zegeer, C. \& Roderiguez, D. (2013). "Costs for Pedestrian and Bicyclist Infrastructure Improvements: A Resource for Researchers, Engineers, Planners and the General Public." Prepared for the Federal Highway Administration. University of North Crolina Highway Safety Research Centre. Retrieved from:

https://www.google.ca/url?sa=t\&rct=j\&q=\&esrc=s\&source=web\&cd=3\&cad=rja\&uact=8\&ved=0 CC8QFjAC\&url=http\%3A\%2F\%2Fwww.pedbikeinfo.org\%2Fcms\%2Fdownloads\%2FCounterme asure_Costs_Summary_Oct2013.pdf\&ei=m7QpVezuI8ykyATe3oHYCQ\&usg=AFQjCNH4vZ4W 8PHpSVjxhw264-z9qhXEAQ

Canadian Mortgage and Housing Corporation (CMHC). (2014). Housing Options for People Living with Dementia. Retrieved from: https://www03.cmhcschl.gc.ca/catalog/productDetail.cfm?cat=17\&itm=20\&lang=en\&fr=1428877235213

City of Toronto. City Solicitor and General Manager, Transportation Services. (2008). Staff Report Action Required: Update on the City's Accessible Pedestrian Signals (APS) Retrofit Program and an Ontario Human Rights Complaint Involving the City's Provision of APS. Retrieved from: http://www.toronto.ca/legdocs/mmis/2008/pw/bgrd/backgroundfile-10400.pdf

Colliers International Canada. (2014). Cap Rate Report, Q3, 2014. Retrieved from: http://renx.ca/wpcontent/uploads/2014/10/14oct16-ColliersQ3-caprates1.pdf

Duggan, S., Blackman, T., Martyr, A., \& Van Schaik, P. (2008). The impact of early dementia on outdoor life: a 'shrinking world'? Dementia 7 (2), 191-204.

Friedman, M. (2015). The Inflation Calculator - all data from the Statistical Abstracts of the United States. Retrieved from: http://www.westegg.com/inflation/

Goodchild, C., \& Rippon, S. (2011). Dementia and the Big Society: Report from Think Tank 16th. London: Department of Health. Retrieved from: http://thehalcyonproject.co.uk/wpcontent/uploads/2011/03/Report-Dementia-and-the-Big-Society-Think-Tank-16-Feb-2011final.pdf 
Gräske, J., Fischer, T., Kuhlmey, A., \& Wolf-Ostermann, K. (2012). Dementia-specific quality of life instruments and their appropriateness in shared-housing arrangements-a literature study. Geriatric Nursing (New York, N.Y.), 33 (3), 204-216. doi:10.1016/j.gerinurse.2012.01.001

Hauch, V. (2013, July 14 $\left.{ }^{\text {th }}\right)$."Visit to Toronto's Pricey Automated Toilet Not Always Flush with Success," The Toronto Star. Retrieved from:

http://www.thestar.com/news/gta/2013/07/04/visit_to_torontos_palatial_potty_not_always _flush_with_success.html

Hopkins, R. W. (2010). Dementia Projections for the Counties, Regional Municipalities, and Census Divisions of Ontario. Kingston, ON: PCCC Mental Health Services. Retrieved from http://www.alzheimertoronto.org/pdf/brochures/Hopkins2010.pdf (p. 59).

Innovations in Dementia. (2011). Dementia Capable Communities: the views of people with dementia and their supporters. Innovations in Dementia. Retrieved from:

http://www.innovationsindementia.org.uk/DementiaCapableCommunities_fullreportFeb201 1.pdf

Keady, J., Campbell, S., Barnes, H., Ward, R., Li, X., Swarbrick, C., Burrow, S. \& Elvish, R. (2012). Neighbourhoods and dementia in the health and social care context: a realist review of the literature and implications for UK policy development. Reviews in Clinical Gerontology, 22(02), 150-163.

Lynch, K. (1960). The Image of the City. Cambridge, Massachusetts: MIT Press.

McDonald, S. (2011). Ontario's Aging Population: Challenges and Opportunities (Information Report) (p. 34). Toronto: Ontario Trillium Foundation. Retrieved from http://www.otf.ca/en/knowledgeSharingCentre/resources/aging_population.pdf

Medical Officers of Health in the GTHA. (2014). Improving Health by Design in the Greater TorontoHamilton Area. Retrieved from: https://www.peelregion.ca/health/resources/healthbydesign/pdf/moh-report.pdf

Meridian Planning Consultants. (2011). Whitby Official Plan Review: Planning Our Built Environment, Draft Policy Discussion Paper. Retrieved from: http://www.whitby.ca/en/resources/pl-community_oprpdp-builtenvironment-p201111.pdf

Mitchell, L., Burton, E., Raman, S., Blackman, T., Jenks, M. \& Williams, K. (2003). Making the outside world dementia-friendly: design issues and considerations. Environ Planning B: Planning Design, 30, 605-32.

Mitchell, L., \& Burton, E., \& Raman, S. (2004). Dementia-friendly cities: designing intelligible neighbourhoods for life. Journal of Urban Design 9, 89-101.

Mitchell, L., \& Burton, E. (2006). Neighbourhoods for life: Designing dementia-friendly outdoor environments. Quality in Ageing: Policy, practice and research 7, 26-33. 
Mitchell, L. (2007). Neighbourhoods for life: the outdoor environment. Journal of Dementia Care, 15, 36-37.

Mitchell, L., \& Burton, E. (2010). Designing dementia-friendly neighbourhoods: helping people with dementia to get out and about. Journal of Integrated Care, 18, 12-19.

Mitchell, L., \& Burton, E. (2012). Chapter 7: Dementia-friendly neighbourhoods - a step in the right direction. In Pollock, A. \& Marshall, M. (Eds.), Designing outdoor spaces for people with dementia (1st Ed.). Stirling, UK: HammondPress and DSDC.

Passini, R., Rainville, C., Marchand, N., \& Joanette, Y. (1998). Wayfinding and Dementia: Some Research Findings and a New Look at Design. Journal of Architectural and Planning Research, 15 (2), 133-151.

Passini, R., \& Marchand, N. (2001). A Multiple Case Study of Wayfinding in Dementia of the Alzheimer Type: Decision Making. Aging, Neuropathy, and Cognition: A Journal on Normal and Dysfunctional Development, 8 (1), 54-71.

Peiser, R. B. \& Hamilton, D. (2012). Professional real estate development: the ULI guide to the business ( $3^{r d}$ Ed.). Washington, DC: Urban Land Institute.

Pollock, A., \& McMair, D. (2012). Chapter 2: Going outside is essential for health and wellbeing. In Pollock, A. \& Marshall, M. (Eds.), Designing outdoor spaces for people with dementia (1st Ed.). Stirling, UK: HammondPress and DSDC.

Province of Ontario. Ministry of Municipal Affairs and Housing. (2014). Provincial Policy Statement. Retrieved from: http://www.mah.gov.on.ca/Page10679.aspx

Province of Ontario. Ministry of Municipal Affairs and Housing. (2006). Growth Plan for the Greater Golden Horseshoe. Retrieved from:

https://www.placestogrow.ca/index.php?option=com_content\&task=view\&id=9\&Itemid=14

Przydatek, M. (2014). Remembering Community Settings: Exploring dementia-friendly urban design in British Columbian municipalities (Thesis submitted for a Master of Arts in the Social Dimensions of Health). University of Victoria, Victoria, BC. Retrieved from: http://hdl.handle.net/1828/5540.

Redel, D. (2015, February 23). You are Here. Ideas with Paul Kennedy on CBC Radio One. Podcast retrieved from: http://www.cbc.ca/radio/ideas/you-are-here-1.2965462

Region of Durham. Planning and Economic Development Department. (2013). Regional Official Plan. Retrieved from: https://www.durham.ca/planed.asp?nr=/departments/planed/planning/op_documents/dr_ official_plan_2008/officialplaninside.htm\&setFooter=/includes/planningFooter.inc

ResilientCity. (2015). Urban Design Principles. Retrieved from: http://www.resilientcity.org/index.cfm?pagepath=Resilience/Urban_Design_Principles\&id= 11928 
Sheehan, B., Burton, E., \& Mitchell, E. (2006). Outdoor wayfinding in dementia. Dementia, 5(2), 271-81. DOI: $10.1177 / 1471301206062254$

Shoval, N., Wahl, H., Auslander, G., \& Isaacson, M. (2011). Use of the global positioning system to measure the out-of-home mobility of older adults with differing cognitive functioning. Ageing and Society (31), 849-869.

Town of Newmarket. Engineering Services. (2009). User Fees - Schedule E. Retrieved from: http://www.newmarket.ca/recreationplaybook/resources/408005_2009_engineering_servic es_user_fees.pdf

Town of Whitby. (2015). Accessibility Advisory Committee - Role. Retrieved from: http://www.whitby.ca/en/townhall/accessibilityadvisorycommittee.asp

Town of Whitby. Planning and Development Department. (2005). Accessibility Standards. Retrieved from: http://www.whitby.ca/en/resources/pw-guideline_accessibilitystandards.pdf

Town of Whitby. Planning and Development Department. (2010). Official Plan, Office Consolidation. Retrieved from: http://www.whitby.ca/en/residents/currentofficialplan.asp

Town of Whitby. Planning and Development Department. (2014). By-law \#6926-14 Parking Standards. Retrieved from:

https://whitby.civicweb.net/FileStorage/A6AF60A8853B44DFAF768972B297C7B0-Bylaw\%20No.\%206926-14\%20Zoning\%20By-law\%20Amendment.pdf

Town of Whitby. Planning and Development Department. (2014). Development Charges. Retrieved from: http://whitby.ca/en/resources/csx-developmentcharbesJuly12014p20140623.pdf

Town of Whitby. Planning and Development Department. (2014). Zoning By-law 2585, Office Consolidation. Retrieved from: http://www.whitby.ca/en/townhall/zoningbylaws.asp

Town of Whitby. Planning and Development Department. (2015). Landscape Plan Guidelines for Site Plan and Subdivision Developments. Retrieved from: http://www.whitby.ca/en/resources/plxguidelines_LandscapePlanGuidelinesforSitePlanandSubdivisionDevelopments-201407.pdf

Town of Whitby. Public Works Department. (2011). Engineering Design Criteria. Retrieved from: http://www.whitby.ca/en/resources/pw-guidelines_engineeringdesigncriteriap20110718.pdf

Van Schaik, P., Martyr, A., Blackman, T., \& Robinson, J. (2008). Involving persons with dementia in the evaluation of outdoor environments. CyberPsychology \& Behavior, 11 (4), 415-24.

Victoria Transportation Policy Institute. (2013). Transportation Cost and Benefit Analysis II Parking Costs. Retrieved from: http://www.vtpi.org/tca/tca0504.pdf

Wong, L. (2015, March 25th). "Core Challenge: Revitalization Planned for Downtown Whitby" Novae Res Urbis GTA Edition. Vol. 18, No. 12, p. 7. 
XE. (2015). XE Currency Converter - USD to CAD. Retrieved from: http://www.xe.com/currencyconverter/

Yevchak, A.M., Loeb, S.J., \& Fick, D.M. (2008). Promoting cognitive health and vitality: a review of clinical implications. Geriatric Nurse, 29, 302-10. 